UNIVERSIDADE DE SÃo PAUlo

FACULDADE DE EDUCAÇÃO

ELISA VIEIRA

\title{
A intensificação da experiência educacional contemporânea: uma perspectiva arqueogenealógica
}


ELISA VIEIRA

\section{A intensificação da experiência educacional contemporânea: uma perspectiva arqueogenealógica}

(versão corrigida)

Tese apresentada à Faculdade de Educação da Universidade de São Paulo para obtenção do título de Doutora em Educação.

Orientador: Prof. Dr. Julio Groppa Aquino 
AUTORIZO A REPRODUÇÃO E DIVULGAÇÃO TOTAL OU PARCIAL DESTE TRABALHO, POR QUALQUER MEIO CONVENCIONAL OU ELETRÔNICO, PARA FINS DE ESTUDO E PESQUISA, DESDE QUE CITADA A FONTE.

Catalogação na Publicação

Serviço de Biblioteca e Documentação

Faculdade de Educação da Universidade de São Paulo

37.017

Vieira, Elisa

V818i

A intensificação da experiência educacional contemporânea: uma perspectiva arqueogenealógica / Elisa Vieira; orientação Julio Groppa Aquino. São Paulo: s. n., 2016.

196 p.; grafs.; tabs.

Tese (Doutorado - Programa de Pós-Graduação em Educação. Área de Concentração: Sociologia e Educação) - - Faculdade de Educação da Universidade de São Paulo.

1. Educação não escolar 2. Pedagogização 3. Educacionalização 4. Crise educacional 5. Periódicos acadêmicos 6. Foucault, Michel I. Aquino, Julio Groppa, orient. 
Nome VIEIRA, Elisa

Título: A intensificação da experiência educacional contemporânea: uma perspectiva arqueogenealógica

Tese apresentada à Faculdade de Educação da Universidade de São Paulo para obtenção do título de Doutora em Educação.

Orientador: Prof. Dr. Julio Groppa Aquino

Aprovada em:

Banca examinadora:

Prof. Dr.

Instituição:

Julgamento:

Assinatura:

Prof. Dr.

Instituição:

Julgamento:

Assinatura:

Prof. Dr.

Instituição:

Julgamento:

Assinatura:

Prof. Dr.

Instituição:

Julgamento:

Assinatura:

Prof. Dr.

Instituição:

Julgamento:

Assinatura: 


\section{AgradeCIMENTOS}

Foram muitos os encontros e as presenças ao longo dos anos em que este trabalho se desenrolou, apesar das minhas repetidas ausências. A todos eles, sou sinceramente grata. O caminho teria sido sem dúvida menos belo não fosse a sorte de tê-los comigo. Também sou grata ao próprio caminho, que se revelou ocasião de afetos tão bem-vindos.

À Universidade de São Paulo agradeço, uma vez mais, a guarida institucional.

À FAPESP, as condições para que eu pudesse me dedicar integralmente à pesquisa, por meio dos processos de $n^{0}$ 2013/14054-5 e 2013/26552-0.

Ao meu orientador, professor Julio Groppa Aquino, a valentia de se fazer dragão e, ainda assim, ser de uma presença desmedida. Nunca terei palavras o bastante para manifestar o tamanho exato da minha gratidão.

Aos professores Carlos Ernesto Noguera-Gonzalez, Cintya Regina Ribeiro, Karla Saraiva, Marcos Francisco Martins e Marilia Pontes Sposito, agradeço a disponibilidade à leitura e ao pensamento compartilhado.

Ao professor Jorge Ramos do Ó e aos colegas de seus seminários de pesquisa na Universidade de Lisboa, sou grata pela sempre gentil acolhida para que parte deste percurso pudesse ser trilhada sob outros ares, os quais se tornaram tão caros a mim.

Aos amigos queridos do grupo de orientação, grande divisor de águas de uma vida, a todos os que por ele passaram, os que permaneceram e os que há pouco chegaram, repito: vocês me são a possibilidade de pensar para além da minha cabeça. Sem isso, nada - nada - teria feito sentido.

Ao Hugo, imprescindível, agradeço por emprestar graça, leveza e permanência quando a aridez insistia em me afligir.

À minha família, por criar lugares tão bons de se pertencer. Sobretudo aos meus pais, Teresinha e Luiz, e à minha irmã, Marcela, por nunca deixarem de acreditar. 
A tarefa à qual as capacidades e os corações republicanos se consagram é construir uma sociedade igual com homens desiguais, reduzir indefinidamente a desigualdade. Porém, quem tomou esse partido só tem um meio de levá-lo a termo: a pedagogização integral da sociedade, isto é, a infantilização generalizada dos indivíduos que a compõem. Mais tarde, chamarse-á a isso formação contínua - co-extensividade entre a instituição explicadora e a sociedade. A sociedade dos inferiores superiores será igual, ela reduzirá suas desigualdades, quando se houver transformado inteiramente em uma sociedade de explicadores explicados.

Uma das lições de Joseph Jacotot (1770-1840) apresentadas por JACQUES RANCIÈRE. 


\section{RESUMO}

VIEIRA, Elisa. A intensificação da experiência educacional contemporânea: uma perspectiva arqueogenealógica. 2016. 196 f. Tese (Doutorado em Educação) - Faculdade de Educação, Universidade de São Paulo, 2016.

A partir da alegação de uma crise educacional generalizada operando na atualidade, a presente investigação devota-se a explorar a conjectura de um expansionismo sem precedentes das práticas educativas no campo social, movimento este consubstanciado na crescente conversão das relações entre os homens em instâncias passíveis de conhecimento e intervenção pedagógicos. Com o fito de perspectivar esse horizonte argumentativo, o corpus do trabalho foi constituído por 930 artigos que evocaram temáticas educacionais extraescolares em 34 periódicos acadêmicos nacionais de destaque, considerados em um intervalo temporal que se estendeu de 1944 a 2015. Tal produção discursiva foi analisada de acordo com um duplo viés teórico-metodológico inspirado no pensamento de Michel Foucault. De um lado, ao perscrutar os textos publicados no período compreendido entre 1996 e 2015, a investigação visou dimensionar os movimentos fronteiriços do campo pedagógico contemporâneo por meio da composição de um inventário das práticas e dos saberes voltados a experiências não escolares, estas consideradas na ampla escala que o arquivo constituído possibilitou traçar. De outro lado, a partir de uma abordagem específica da Revista Brasileira de Estudos Pedagógicos, a qual abrangeu todos os fascículos publicados até 2015 desde sua fundação, em 1944, tratou-se de circunscrever os contextos de emergência/proveniência atinentes a tal espraiamento dos domínios educacionais. Como saldo analítico da investigação, desponta uma perspectiva adversativa às discussões atuais concernentes a processos reconhecidos como educacionalização, pedagogização e escolarização sociais, sobretudo em virtude da intensa permeabilidade das práticas escolares às múltiplas demandas do presente. Daí a assunção de que os processos de subjetivação contemporâneos redundariam em uma acentuada educabilização da experiência civil, esta consoante a determinados jogos de veridicção calcados em uma demarcada matriz pedagógico-escolarizante.

Palavras-chave: Educação não escolar; Pedagogização; Educacionalização; Crise educacional; Periódicos acadêmicos; Michel Foucault. 


\begin{abstract}
VIEIRA, Elisa. The intensification of the contemporary educational experience: an archaeo-genealogical approach. 2016. 196 f. Tese (Doutorado em Educação) - Faculdade de Educação, Universidade de São Paulo, 2016.

Considering the allegation of a widespread educational crisis taking place in the present, this investigation is dedicated to exploring the assumption of an unparalleled expansionism of educative practices in the social field, a process which is characterized by an increasing conversion of the relationship between individuals into objects susceptible to pedagogical knowledge and intervention. With the aim of inspecting this argumentative horizon, 930 papers evoking educational out-of-school themes formed the research corpus, all of them published in 34 national academic journals through the period 1944-2015. This discursive production was analyzed according to a double theoretical-methodological approach inspired in Michel Foucault's thought. On the one hand, by examining the texts published between 1996 and 2015, the investigation attempted to dimension the borderline movements in the contemporary pedagogical field by means of an inventory of practice and knowledge focused on out-of-school experiences, the latter considered within the wide scale the archive thus built enabled to outline. On the other hand, in accordance with a specific approach of the Brazilian journal Revista Brasileira de Estudos Pedagógicos, which comprised all the issues published from its foundation, in 1944, to 2015, the intention was to circumscribe the contexts of emergence/provenance regarding the enlargement of educational realms. As an analytic outcome of the investigation, what is offered is an adversative perspective before the current discussions on processes identified as social educationalization, pedagogization and scholarization, mostly by virtue of an intense permeability of school practices to current demands. Thus, the assumption that contemporary subjectification processes would promote a marked educabilitization of the civil experience, the latter in congruence with certain veridiction games based on a strong pedagogical-schooling emphasis.
\end{abstract}

Keywords: Out-of-school education; Pedagogization; Educationalization; Educational crisis; Academic journals; Michel Foucault. 


\section{SUMÁRIO}

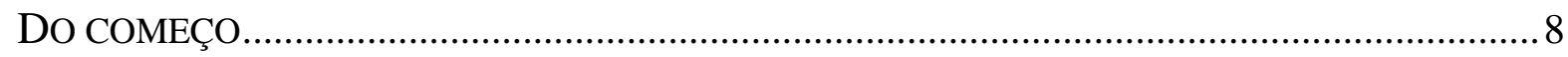

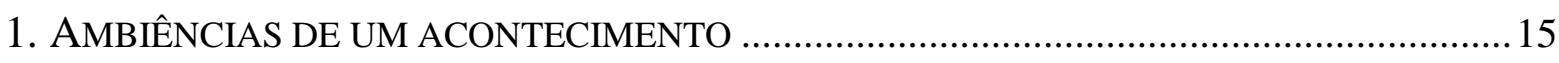

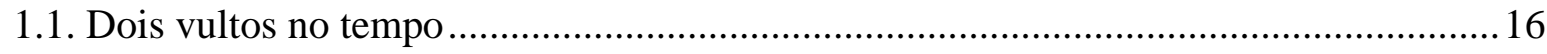

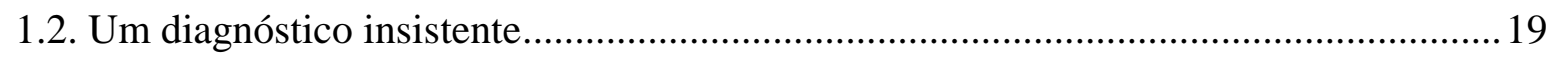

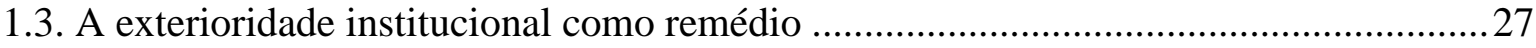

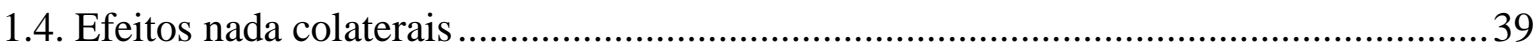

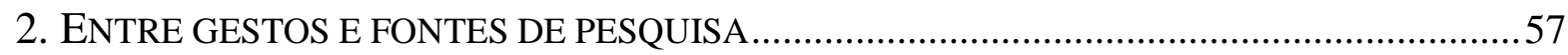

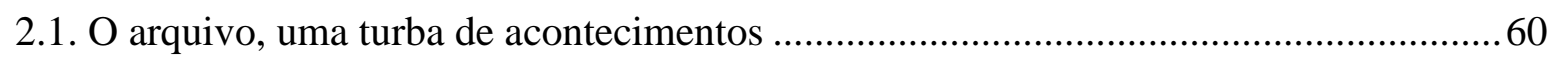

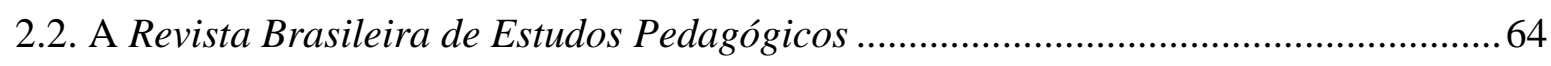

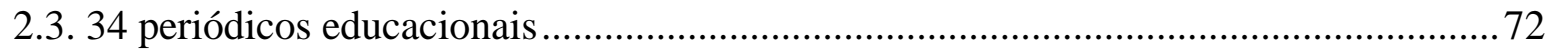

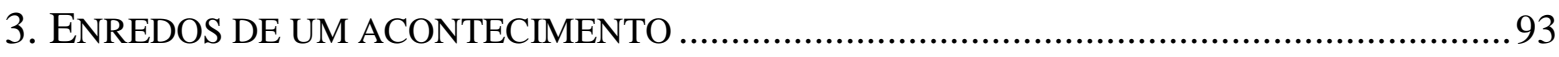

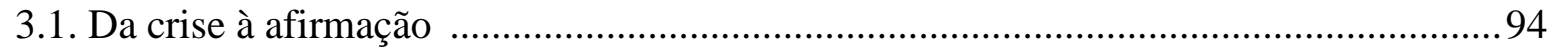

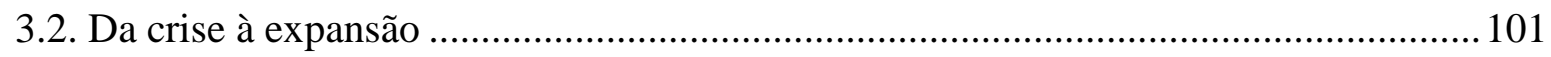

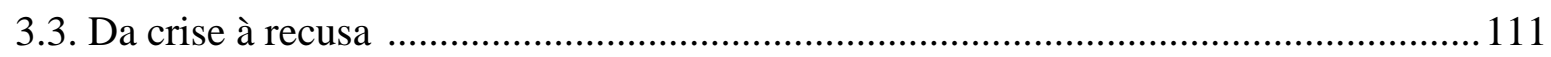

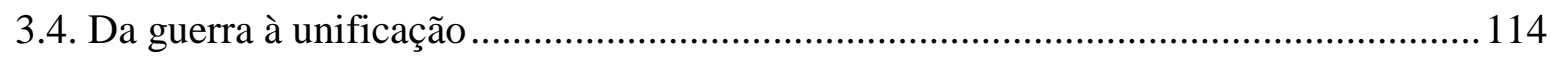

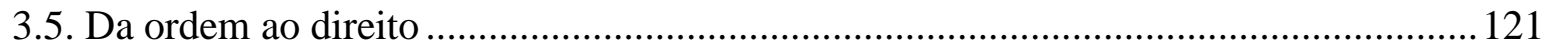

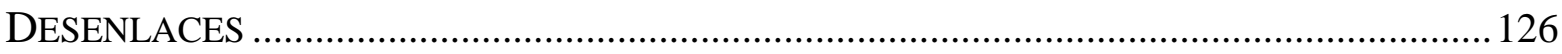

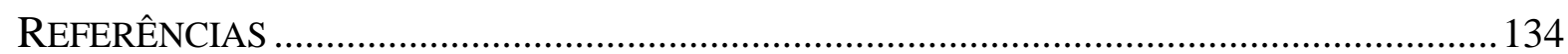

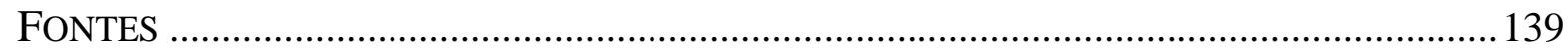




\title{
DO COMEÇO
}

\author{
Porque afinal cada começo \\ é só continuação \\ e o livro dos eventos \\ está sempre aberto no meio.
}

WISLAWA SZYMBORSKA

\section{Como se começa uma tese?}

Que ela só exista à medida que se formula, à medida que se desenrola nas linhas imprevistas de certo percurso de pesquisa e pensamento, é conclusão fácil à trama que aqui se pretendeu tecer. Mas por onde, precisamente, ela começa? Será pela formulação das perguntas que a ensejam? Será pelos descaminhos que se impõem ao caminho traçado? Será, antes, por um de nossos encontros - dos tantos possíveis - com o arquivo do mundo?

Se tal indagação esbarra o insondável, também o próprio começar, por vezes, pode ser tarefa árdua, sobretudo quando é pelos começos que se interroga - lá onde o que há não é a solenidade, a essência, mas "é a discórdia entre as coisas, é o disparate", diria Michel Foucault (2005, p. 18).

Neste caso, trata-se do disparate de uma experiência que nada tem de privada, mas que é intimamente partilhada por todos aqueles que se voluntariam de bom grado a percursos formativos sem fim - os próprios e os alheios, os de agora e os vindouros. Experiência comum aos coetâneos de um mundo seduzido pela insígnia educativa. Experiência nossa, desse nós que hoje nos tornamos: sujeitos aprendizes.

Aí, talvez, os traços de um dos começos mais latos desta pesquisa: o espanto perante algo tão prosaico e, ao mesmo tempo, tão crucial ante nós mesmos. Prosaico porque, de tão onipresente, muitas vezes sequer atinamos a essa dimensão educativa em nossa relação com o mundo. Crucial porque, no entanto, ela é constitutiva do nosso modo de vida. Mas poderia não ser - e eis a razão do espanto. Ou de sua forja, já que tampouco o espanto é espontâneo.

Afinal, como é possível espantar-se com os contornos de uma experiência quando se é o exato fruto dela? Como é possível estranhar aquilo que nos é mais familiar? Sem dúvida, é sempre a partir dessa experiência, e não de outra, que falamos. E é também por esse motivo que o fazemos: porque é só a partir de um dentro e de um tempo que se pode pensar. Tais são alguns dos paradoxos com os quais será preciso conviver desde já. Se apesar deles nos lançamos ao risco, não é pela promessa de alcançar umamos fora de onde se possa, então, 
finalmente vislumbrar o que se nos passa cá dentro. É, antes, pela aposta na possibilidade de criar alguma distância entre enunciados alinhavados e justapostos, mas cujos liames poderiam seriam outros. Trata-se, nesse sentido, de esgarçar os limites do dizível de um tempo, desfamiliarizar, artificializar aquilo que se naturalizou; de ter por horizonte a indagação incessante: como foi que nos tornamos sujeitos potencialmente aprendizes em tempo integral, do início ao termo de nossas vidas?

Não obstante a grandiloquência que pode porventura emanar de tais anseios, a tarefa é modesta, conforme se verá. E esta definitivamente não será a primeira, tampouco a última tentativa de fazê-lo. Daí a pretensão de adentrar um debate já em curso, nesse grande livro de eventos aberto no meio. Nada além de um encontro possível com o arquivo do mundo.

Mas há outros começos mais precisos a serem mencionados. Entre eles, o esforço investigativo conjunto de um grupo de pesquisadores dedicados a analisar tal pujança educacional de nossos dias em variados âmbitos, sobretudo a partir da conjectura de que haveria um modus operandi pedagógico/pedagogizante a investir práticas sociais não imediatamente referidas ao campo educacional (AQUINO, 2015). ${ }^{1}$ Foi no bojo das discussões aí levadas a cabo que este estudo se formulou.

Para além de uma hipótese explicativa geral, tais pesquisas têm em comum um referencial teórico-metodológico inspirado no pensamento de Michel Foucault, com destaque para suas concepções de governamentalidade, genealogia e crítica. A respeito desta última, as palavras do pensador francês resumem precisamente o gesto perseguido nesse conjunto investigativo: para ele, a crítica "não consiste em dizer que as coisas não são bem como são. Ela consiste em ver em que tipo de evidências, de familiaridades, de modos de pensamento adquiridos e não refletidos repousam as práticas que aceitamos" (FOUCAULT, 2013c, p. 356).

Também se inseriu nesse contexto a dissertação de mestrado (VIEIRA, 2012) que antecedeu o presente trabalho. Disparada pela aliança contemporânea entre urbanidade e educação, a referida pesquisa tomou tal aliança como parte e indício de uma dinâmica mais ampla de investimento nos processos educativos que se engendram no exterior escolar. $\mathrm{Na}$

\footnotetext{
${ }^{1}$ Grupo de pesquisadores (de iniciação científica a pós-doutorado) reunidos sob a orientação do Prof. Julio Groppa Aquino, na Faculdade de Educação da Universidade de São Paulo.
} 
ocasião, o mote da análise residia na noção de cidade educadora, proposta difundida e efetivada nas últimas décadas como estratégia de gestão urbana em diversas localidades ao redor do mundo, inclusive no Brasil.

Sob a consideração de que o lastro educacional de iniciativas dessa ordem não seria algo exclusivo do tempo presente, tratou-se, naquela ocasião, de perspectivar tal horizonte segundo um plano estratégico composto por outros modelos de cidade considerados ideais em diferentes momentos históricos. Assim, a primeira parte da investigação consistiu na composição de um cenário analítico debruçado sobre quatro projetos urbanos entendidos como ficcionais (A República, de Platão; Utopia, de Thomas More; Cidade do Sol, de Tommaso Campanella; e Walden II, de Burrhus Frederic Skinner), todos eles com um traço educacional em evidência.

Uma vez percorrido tal cenário e tendo em vista o que ele permitiu esboçar acerca das relações entre educação, modos de governo e processos de subjetivação, o problema urbanoeducativo contemporâneo foi examinado mais detidamente. Daí o corolário então entretecido: nas relações urbanas de nosso tempo, a tarefa educativa estaria convertida em papel de todos e de cada um, redundando em um efeito imediatamente educador na própria forja subjetiva. Uma educação total, de si e dos outros, portanto, parecia ser a realização máxima da utopia urbano-educadora, a qual findaria por decretar uma espécie de alunização radical dos sujeitos contemporâneos.

Como um dos saldos analíticos da investigação levada a cabo, restava patente a existência de uma maquinaria educacional espraiada pelo espaço social citadino, da qual a escola certamente seria parte, mas não peça única. Se cidadão e aluno, em alguma instância, seriam condições complementares, tal sobreposição não era prerrogativa exclusiva da instituição escolar.

No desfecho daquele trabalho, mais um dos começos desta tese: a aproximação ao vasto campo de estudos sobre a educação não escolar. A cidade perdeu seu papel de protagonista temático da análise, dando lugar ao campo disciplinar pedagógico stricto sensu e ao intento de investigar mais detidamente os processos de espraiamento educacional, cujos sintomas materializam-se no contexto urbano.

Surgiu, assim, a presente pesquisa, animada pelo bordão foucaultiano que lhe é caro: a intenção de interrogar sobre aquilo que hoje somos, buscando evidenciar os jogos de governo em que nos encontramos inseridos. Nesse sentido, o interesse pela área da educação, desde 
antes, justifica-se devido à consideração de ser ela uma das instâncias intimamente envolvidas na produção dos modos contemporâneos de veridicção/subjetivação. Afinal, do senso comum ao discurso técnico, a educação é hoje vista como onipresente, temporal e espacialmente, à experiência humana. Daí a escolha pelo âmbito educacional não escolar: dizer que somos sujeitos aprendizes significa dizer que o somos em tempo integral na extensão da vida sobretudo fora da escola.

Foi também ao largo das alegações de uma crise escolar na contemporaneidade que esta pesquisa se moveu. Da alegação da crise à suposição de um espraiamento do intento educativo para além dos limites escolares, a investigação que ora se apresenta projetou suas trilhas, orientada pelo propósito de lançar luz a certo apogeu educacional - extraescolar, não escolar, não formal, informal, popular, social, entre tantas outras designações que disputam lugar nos escritos sobre o assunto. Às assertivas que constatavam uma suposta exiguidade, as investigações que subsidiaram este estudo opunham o excesso, a pulverização - em outros espaços, porém. Se a escola parecia claudicar, o mesmo não se dava com as práticas educativas sediadas fora dela. A educação certamente exuberaria alhures, sem crise, sem limite.

Assim, a partir da hipótese de que experiências educativas não escolares estariam a adquirir centralidade cada vez mais proeminente no interior do campo educacional, a intenção foi analisar os processos que vêm enredando as relações entre os homens e as experiências da vida como objetos passíveis de conhecimento e intervenção de natureza pedagógica, além de pôr à prova os próprios contornos da premissa de partida. Junto a ela, uma conjectura préanalítica a transtornava em forma de problema de pesquisa: se a suposição de tal expansionismo pedagógico fosse plausível, tratar-se-ia de um movimento que alega reconhecer um caráter educativo subjacente às relações e experiências da vida, investindo-as de uma intencionalidade determinada. Se supusermos com Foucault, porém, que não há objetos a priori, mas objetivações ininterruptas, somos levados a interrogar sobre as relações veridictivas que aí se forjam, entendendo que um investimento dessa monta acaba por produzir focos de experiência ${ }^{2}$ que passam a compor os modos de governo das populações.

Entre formulações assim amplas, diversas são as veredas investigativas possíveis por onde seguir, conforme se tem visto na literatura acadêmica em torno de temáticas afins. Não

\footnotetext{
${ }^{2}$ Foucault (2010a, p. 4) define focos de experiência como a articulação entre três elementos: "primeiro, as formas de um saber possível; segundo, as matrizes normativas de comportamento para os indivíduos; e enfim os modos de existência virtuais para sujeitos possíveis".
} 
sendo exclusiva deste estudo, tal conjectura é motor de uma rede de outros trabalhos, seja para afiançá-la, para analisá-la, para depreciá-la, ou ainda para expandir seu campo de efetivação. Parte de tal produção acadêmica, aliás, será adiante mobilizada, pois é no âmbito dessa discussão que a presente empreitada tencionou inscrever-se. Somou-se a ela um conjunto bibliográfico substancial, constituído pela produção textual veiculada em periódicos educacionais brasileiros.

A fim de compor um inventário de como a tônica não escolar comparece em tal material, bem como de localizar emergências e proveniências de problemáticas a ela relacionadas no interior do discurso pedagógico, foram traçadas duas estratégias de abordagem. De um lado, uma incisão cronologicamente mais estendida, percorrendo 72 anos de existência da Revista Brasileira de Estudos Pedagógicos (entre 1944, ano de sua fundação, e 2015, limite temporal final estabelecido para a execução da pesquisa). De outro lado, um levantamento concentrado nas publicações veiculadas nas duas últimas décadas (1996-2015) por 34 periódicos nacionais da área educacional (incluída a própria $R B E P$ ). A seleção totalizou 930 textos recolhidos, somadas as duas porções do material.

Uma explanação mais detida das decisões e dos procedimentos aí envolvidos, bem como uma especificação detalhada de tal arquivo encontram-se expostas no segundo capítulo deste trabalho, que consiste em uma espécie de intervalo teórico-metodológico necessário para explicitar o tratamento rendido ao corpus propriamente empírico da pesquisa - aquilo que é sua especificidade. O inventário constituído foi, em si mesmo, um dos objetivos que o trabalho se atribuiu, a título de oferta ao campo das pesquisas educacionais. De fato, as possibilidades de decomposição do que ali se apresenta são muitas e abrem espaço a problemas de pesquisa variados, estando absolutamente disponíveis a investigações por vir.

Embora pormenorizado apenas na segunda seção do texto, o arquivo derivado dos 34 periódicos educacionais já se faz presente no primeiro capítulo. Dedicada a revisitar argumentos e discussões correntes sobre o assunto, a primeira seção do texto se desenrola de modo a circunstanciar o problema central da pesquisa no interior de debates já em curso, além de explicitar algumas das perspectivas que orientaram a pesquisa. É válido adiantar que, quando aqui se questionam argumentos já tecidos sobre os assuntos em pauta, não se pretende desbancá-los em favor de uma análise mais verdadeira, mais fidedigna ou mais aderida a uma suposta realidade. Antes, a partir de tais divergências, intentou-se pôr em operação uma engrenagem analítica própria que correspondesse aos anseios deste trabalho, além de fornecer a ela alguns antídotos contra os caminhos que se procurava evitar. 
Assim, no primeiro capítulo, a temática da educação não escolar aparece situada entre as diversas alegações a respeito de uma crise do campo educacional e as análises que vêm apontando uma ampliação crescente do escopo pedagógico. Embora se tenha partido também de uma revisão bibliográfica para a composição dessa porção do texto, trata-se já de uma investida analítica atravessada pelo material empírico da pesquisa, de modo que todas as peças textuais mobilizadas acabaram por compor um arquivo expandido. Daí não se encontrar ali um levantamento descritivo e extenuante de tal debate, mas sim uma decomposição crítica, inspirada pela suspeita dos consensos identificados e sustentada pelas particularidades e possibilidades fornecidas pelas fontes investigadas.

O terceiro capítulo, por sua vez, apresenta-se como uma composição de excertos analíticos que se articulam sequencialmente. Procurou-se, sobretudo, dar movimento àquilo que aparece como estático na primeira porção do arquivo, na tentativa de restabelecer os jogos agonísticos intrínsecos às práticas que ensejaram a experiência educacional contemporânea.

A última seção procura arrematar alguns dos fios analíticos levantados. Trata-se não de uma exposição convicta de resultados, mas de uma recolha possível dos deslocamentos operados. Nesse sentido, uma advertência que é também válida para o trabalho como um todo, de ponta a ponta cravado de indagações. Quando, em vez de suspeições, encontrarem-se aparentes convicções, que não haja engano: o esforço da coerência por vezes trai os hiatos entre um extremo e outro do pensamento.

Ainda sobre a composição do texto, ela seguiu menos a lógica de um quebra-cabeças, mais afeita que foi à trama de uma colcha de retalhos. Se, naquele, o resultado ao final da junção das peças é uma figura bem delimitada que estava lá prevista desde o início, mas que só é possível ver após o encaixe perfeito das partes, o arranjo dos retalhos de uma colcha é de ordem fortuita: composição de estampas e texturas não imediatamente conciliáveis - e que bem poderiam ser outras -, mas cuja combinação tem por efeito a forja de um campo de visibilidade que antes era infenso ao olhar e à predição.

Por fim, no que concerne às justificativas para uma tal empreitada, é de se prever que elas por vezes podem chocar-se com a alegação de que o espraiamento do intento educacional é favorável ao progresso, à democratização, ao desenvolvimento. Contudo, como bem afirmam Popkewitz, Olsson e Petersson (2009), é preciso historicizar o senso comum - no caso, aquele que defende a educação e sua expansão como bens inquestionáveis - e diagnosticar cerceamentos em curso, uma vez que os princípios de uma sociedade atravessada pelo vetor educacional estão inseridos em formas de governamento, constituindo efeitos de 
verdade. Formas e efeitos estes nem execráveis, nem desejáveis a priori, vale lembrar, mas indubitavelmente resultantes das forças que nos afetam e nos subjetivam dia a dia, mesmo - e sobretudo - quando não o notamos.

Historicizar o senso comum acerca do trabalho educacional nos dias atuais: eis um dos objetivos perseguidos. Como já dito, é necessário distanciar-se para enfim se poder aproximar daquilo de que se está próximo demais. A atualidade do recorte temporal eleito talvez não permita encontrar tamanha distância, senão um retrato mais ampliado do que somos - ou do que já estamos deixando de ser. Nisso, entretanto, algum estranhamento decerto será possível.

Transtornemos em indagações, pois, o senso que hoje nos é comum: de que modo se produziu uma sociedade plenamente educável? Como chegamos a pensar o que hoje, no plano educacional, pensamos em consenso? Que matrizes de pensamento forneceram as bases sobre as quais aquilo que hoje somos tornou-se possível? Ou, então, que problematizações foram postas em movimento para que se pudesse formular os objetos atuais de nosso pensamento?

Há aí questões demasiado abrangentes, sem dúvida, e que abrem margem a um vasto campo analítico - que ele seja, oxalá, cada vez mais explorado. Das possibilidades de tangenciá-las, foi uma delas, mas restrita e específica, que aqui se pretendeu experimentar: o que o arquivo constituído nesta pesquisa tem a nos dizer quando a ele lançamos tais indagações? 


\title{
1. AMBIÊNCIAS DE UM ACONTECIMENTO
}

Em um dos célebres contos de Caio Fernando Abreu - Os dragões não conhecem o paraíso -, é também pela hesitação ante os começos que somos apresentados à matéria da narrativa que se ensaia iniciar.

\begin{abstract}
Ainda não comecei.
Queria tanto saber dizer Era uma vez. Ainda não consigo.

Mas preciso começar de alguma forma. E esta, enfim, sem começar propriamente, assim confuso, disperso, monocórdio, me parece um jeito tão bom ou mau quanto qualquer outro de começar uma história. Principalmente se for uma história de dragões. (ABREU, 2005, p. 130)
\end{abstract}

Os dragões aludidos pelo personagem do escritor gaúcho não conhecem o paraíso. Mais que isso, "eles fogem do paraíso, esse paraíso que nós, as pessoas banais, inventamos" (ABREU, 2005, p. 136). Invisíveis, impalpáveis, imprevisíveis, impermanentes, são indiferentes aos artifícios de que nos valemos para que nos concedam a graça de uma aparição. "As cortinas não chegam a se abrir para que entrem em cena. Eles se esboçam, se esfumam no ar, não se definem” (p. 135).

Assim como os seres fantásticos ${ }^{3}$ da enciclopédia descrita por Jorge Luis Borges no conto O idioma analítico de John Wilkins, mote inspirador de Foucault (2007) ao prefaciar As palavras e as coisas, tais dragões habitariam um atlas do impossível. Um impossível que não cabe no espaço das utopias. Estas, ao contrário, "permitem as fábulas e os discursos: situam-se na linha reta da linguagem"; seu espaço é "maravilhoso e liso" (FOUCAULT, 2007, p. XIII). Falam elas, talvez, do que é possível projetar a partir do atlas corrente no tempo em que se formulam. Falam elas de paraísos possíveis.

Se os dragões não conhecem o paraíso, tampouco lhes são familiares as utopias, esses supostos paraísos que nós, pessoas banais, inventamos para responder aos problemas de nosso tempo.

Esta definitivamente não é uma história de dragões. Antes, talvez seja uma história de paraísos que vão se forjando à medida que projetamos nossas utopias. Paraísos que, ao se materializarem, evidenciam sua vizinhança com as trevas das quais acreditávamos nos afastar.

\footnotetext{
3 "Quando eu falo de dragões eu falo do mito chinês daqueles animais fantásticos, que não existem" (ABREU apud DIP, 2009, p. 302).
} 


\subsection{Dois vultos no tempo}

"Como educar sem escolas?" - eis a pergunta lançada logo no título de um dos artigos publicados pela Revista Brasileira de Estudos Pedagógicos (RBEP) em 1974. Ainda na primeira página do texto apresentava-se a constatação de que, independentemente das respostas àquela indagação, já se educava sem escolas:

Tal crítica [relativa à insatisfação atual perante a escola] leva muita gente a se perguntar se é possível conceber um processo diferente de educação. Paradoxalmente, estas mesmas pessoas, quando interrogadas sobre a maneira como formaram seus conhecimentos e interesses, admitem com presteza que, na maioria das vezes, aprenderam fora da escola. Conhecimento dos fatos, sua compreensão da vida e do trabalho lhes vieram da amizade ou do amor, de um programa de televisão ou de uma leitura, do exemplo de seus semelhantes ou do acaso de um encontro de rua.

O autor dessas linhas é Ivan Illich [1974, p. 186], ${ }^{4}$ teórico reconhecido pela defesa de uma desescolarização radical. De sua lavra, outros títulos - como Sociedade sem escolas (originalmente publicado em 1970) e A sociedade desescolarizada (em 1973) - já dão a tônica em torno da qual se centravam suas proposições relativas à educação.

O pensador austríaco identificava na instituição escolar o signo de um fracasso generalizado, não obstante entranhado no éthos social. Suas proposições não se davam, todavia, em favor de uma equivalente deseducação da sociedade. Longe disso, Illich propunha que a ausência de escolas possibilitaria justamente uma educação universal. Em suas palavras: "A atual procura de novas saídas educacionais deve virar procura de seu inverso institucional: a teia educacional que aumenta a oportunidade de cada um de transformar todo instante de sua vida num instante de aprendizado, de participação, de cuidado" (ILLICH, 1977, p. 18). Nesse sentido, acreditava Illich, a desinstalação das escolas prestar-se-ia a garantir a efetiva disseminação de funções educativas a um mais amplo espectro espaço-temporal ao longo da vida.

\footnotetext{
${ }^{4}$ A fim de facilitar a identificação das referências durante a leitura, optou-se por estabelecer uma diferença de notação quando se trata da bibliografia incluída na seção "Fontes", em que estão arrolados os textos que compõem o arquivo propriamente empírico da pesquisa. Por se tratar de uma lista específica e demasiado extensa, ela foi reunida separadamente das demais obras (temáticas e teóricas) que serão aqui mobilizadas. Assim, o uso do colchete indica as referências que fazem parte daquela seção, ao passo que o parêntese corresponde às obras elencadas na seção "Referências".
} 
Para tanto, seria preciso que as pessoas resgatassem a responsabilidade por sua própria aprendizagem, esta então demasiado centrada nos expedientes escolares. Afinal, segundo ele, a "desescolarização da sociedade é nada menos do que uma mutação cultural, pela qual um povo recupera o uso efetivo das suas liberdades constitucionais" (ILLICH, 1973, p. 28). Em lugar de um aparato escolarizado à frente da educação da sociedade, o pensador austríaco propunha teias de aprendizagem, “imediatamente disponíveis ao público em geral e elaboradas de forma a darem igual oportunidade para a aprendizagem e o ensino" (ILLICH, 1977, p. 130).

Apesar de se ter consagrado como ícone da crítica radical à instituição escolar e ao sistema por ela sustentado, Illich não reivindicava exclusividade absoluta na formulação de suas ideias. Ao contrário, reconhecia a influência que outros autores haviam exercido em sua obra.

O britânico Everett Reimer é, provavelmente, um dos primeiros da lista. Autor de $A$ escola está morta, livro publicado um ano após Sociedade sem escolas, Reimer manteve com Illich um diálogo de mais de 15 anos em torno de alternativas para o ensino escolar. Ambos compartilhavam a convicção de que se fazia urgente "uma efetiva proibição do monopólio escolar" (REIMER, 1975, p. 27), a ser substituído pelo "acesso universal aos recursos educacionais" (p. 163). Embora sua projeção tenha sido bem menor que a de seu colega austríaco, Reimer ainda é por vezes lembrado quando se trata de pensar a escolarização como estando "organizada e desenvolvida para limitar, doutrinar e, por fim, transmitir valores e conhecimentos que interessam à sociedade almejada por alguns" [CASTILLO, 2013, p. 105].

Vale mencionar, ainda, que àquela mesma época - mais precisamente, em 1973 - era publicada uma compilação de textos diversos a respeito de alternativas educacionais não escolarizadas. Intitulada Educação sem escolas (BUCKMAN, 1973), tal coletânea incluía escritos de Illich e de outros 13 autores, indicando, talvez, que aquela era uma tendência notória entre certo grupo de pensadores da década de 1970.

Mas é em outro dos interlocutores de Ivan Illich que interessa agora centrar atenção: Paulo Freire. Para além da curiosa coincidência de ambos terem vivido por 76 anos - ou quase, já que Freire faleceu alguns meses antes de completar a idade -, os dois nutriram importantes afinidades de pensamento e estiveram em diálogo frequente (FREIRE; ILLICH, 1975). 
O educador pernambucano dispensa apresentações, não apenas em nosso contexto educacional brasileiro, mas também para além dele, já que se tornou uma das referências centrais no âmbito das ditas pedagogias críticas e da educação popular. Com uma obra bastante vasta e já assaz esmiuçada, Freire não será alvo, aqui, de uma nova inspeção em suas minúcias. Antes, importa por ora destacar alguns de seus pontos de contato com a defesa da desescolarização. Daí a relevância do encontro entre o brasileiro e o austríaco.

Apesar de as proposições freireanas, de certo modo, não colocarem radicalmente em questão a legitimidade da existência da instituição escolar - dirá Rui Canário, contrapondo-o a Illich, que "o pensamento de Paulo Freire situa-se dentro dos limites do escolar, não critica o escolar nem o que lhe está agregado" (CANÁRIO; POMBO, 2005, p. 41) -, suas críticas aos padrões educacionais vigentes iam ao encontro das illichianas.

Illich e Freire se aproximam não somente pela crítica que fazem da sociedade na qual vivemos, mas, ainda, pela posição que assumem com relação à função da escola e da educação, colocadas a serviço do sistema capitalista de produção e legitimadas pelo neoliberalismo. Aproximam-se, ainda, porque anunciadores de uma nova sociedade e de uma nova educação [...]. Aproximam-se, também, pela crítica que tecem à escola e por suas propostas de novas práticas pedagógicas que são, ao mesmo tempo, libertadoras e formadoras do homem e da mulher, novos construtores da nova sociedade - uma sociedade de convivialidade, de diálogo, de solidariedade. [MESQUIDA, 2007, p. 562]

Ambos denunciavam, portanto, o que entendiam ser o caráter opressor do sistema educacional, sustentando seus posicionamentos na defesa incondicional da autonomia e da liberdade. A diferença talvez residisse apenas no desenlace em que seus respectivos pressupostos acabavam por desembocar: se os de Illich redundavam na necessidade urgente da desescolarização, os de Freire tinham seu ponto alto na oferta de uma educação libertadora - ou problematizadora, ao que voltaremos adiante.

Ivan Illich e Paulo Freire serão vultos constantes nas páginas que se seguirão, não tanto por opção previamente deliberada, mas pelo papel que seus espectros teóricos adquiriram no trato com as questões das quais este trabalho se ocupou. De todo modo, poderiam ter sido outros os personagens elencados para acompanhar a discussão. A tarefa, assim, não será a de esgotar suas respectivas teorizações, já que não são elas o mote em pauta. Tratar-se-á, apenas, de tomá-los como ocasião para fazer deslocar o pensamento - o deles e o nosso. 
Suponhamos que Freire e Illich tenham apresentado os contornos de seus paraísos, já que com tanta precisão apontaram os traços do que lhes era inferno. Cada um a seu modo, eles nos legaram suas utopias - as utopias de seu tempo, que provavelmente, aliás, ainda é avizinhado ao nosso. Mergulhados no dizível, no visível e no pensável que lhes eram contemporâneos, foram porta-vozes de insatisfações e anseios que não lhes eram exclusivos.

Levantar tais suspeitas não nos leva - e é preciso dizê-lo desde já - a depreciar o efeito revolucionário que suas obras porventura exerceram e ainda exercem, segundo alguns de seus leitores. Tampouco nos possibilita acusá-los de qualquer dolo perante as configurações educacionais que os sucederam. Ambos têm como álibi os disparates da história. Mas é sempre sob as contingências do nosso presente imediato que nos voltamos aos acontecimentos passados. E o que lá parecia subversão pode ser agora perspectivado em outros termos.

Daí mais uma indagação a nos orientar: que paraísos são esses que hoje habitamos?

\subsection{Um diagnóstico insistente}

Também naquele início dos anos 1970, Ivan Illich (1976, p. 99) vaticinava: “Os dias atuais são de crise para a instituição da escola, de uma crise que possivelmente está assinalando o fim da 'era da escolarização' no mundo ocidental”. Apesar da grandiloquência da afirmação, ela reverberava uma hipótese nada nova no horizonte do campo educacional.

Com efeito, diagnóstico semelhante já se fazia presente há algum tempo no debate dos intelectuais da área, e não apenas dela. Exemplo bastante difundido é a análise feita por Hannah Arendt, nos anos 1950, acerca do papel da educação no mundo moderno. Interessada no que julgava ser uma crise social generalizada - equivalente a uma crise moderna da autoridade ou da tradição -, Arendt situava a crise escolar norte-americana como manifestação exemplar do que então se passava também mundo afora. Para ela, se a América configurava-se como mostra extrema de tais circunstâncias críticas, era porque se tratava fundamentalmente de uma terra de imigrantes, aos quais se fazia necessário nacionalizar via escolarização. Em suas palavras:

[...] a explicação técnica consiste obviamente no facto de a América ter sido sempre uma terra de imigrantes. Nestas circunstâncias, é óbvio que só a escolarização, a educação e a americanização dos filhos dos imigrantes 
pode realizar essa tarefa imensamente difícil de fundir os mais variados grupos étnicos. (ARENDT, 2007, p. 23)

Essa conjunção singular seria responsável, segundo a autora, por converter a educação em uma questão fundamentalmente política no contexto norte-americano, embora tais dimensões - educação e política -, em situações ordinárias, fossem por ela reputadas como não convergentes. Em sua avaliação, "a educação não pode desempenhar nenhum papel na política porque na política se lida sempre com pessoas já educadas" (ARENDT, 2007, p. 26).

No entanto, em uma terra de imigrantes, à educação restaria a paradoxal tarefa de levar as pessoas a abandonarem os valores do velho mundo de onde vinham em favor da edificação de raízes no mundo novo que agora habitavam - quando, em verdade, este já era também um mundo velho. Tratava-se, pois, de converter imigrantes em cidadãos nacionais, sendo esta uma função, ao mesmo tempo, educativa e política. Daí um dos cernes da crise identificada por Arendt, também relacionado ao estatuto que a igualdade ali adquiria:

[...] o que faz com que a crise da educação seja tão especialmente aguda entre nós é o temperamento político do país, o qual luta, por si próprio, por igualar ou apagar tanto quanto possível a diferença entre novos e velhos, entre dotados e não dotados, enfim, entre crianças e adultos, entre alunos e professores. (ARENDT, 2007, p. 30)

A crise educacional de que falava a filósofa alemã - residente nos Estados Unidos desde 1941 - era, assim, uma crise social e política. Ou, melhor, parte de seu estatuto de crise derivava da assunção, pela atividade educativa, de funções que invadiam a esfera política.

Anos mais tarde seria publicada A crise mundial da educação, obra escrita em 1967 pelo estadunidense Philip H. Coombs e utilizada como referência inaugural de toda uma vertente de estudos que a ela se seguiram. A partir de dados produzidos pela UNESCO (à época, Coombs ocupava o posto de direção no Instituto Internacional de Planejamento da Educação) e tendo em vista a Conferência Internacional sobre a Crise Mundial da Educação (realizada nos Estados Unidos naquele mesmo ano), o autor apresentou em seu livro um relatório que atestava a inadequação dos aparatos formais de ensino ao redor do mundo. A solução, segundo seu vaticínio, residiria no investimento em um sistema paralelo de educação, não mais centralizado nas práticas escolares. 
O posicionamento de Coombs reverberaria no Brasil logo em seguida, em texto publicado no jornal carioca Correio da Manhã em 1968 e reproduzido na RBEP em 1969. É dessa publicação o seguinte excerto:

Considerando a questão objetivamente, podemos afirmar que os sistemas de educação dos países em desenvolvimento foram atingidos por uma profunda crise cuja natureza básica e causas são de caráter universal. É, em essência, a "crise do desajustamento" entre os sistemas educacionais e o meio ambiente, provocada pela incapacidade dêsses sistemas se transformarem, a fim de adaptar-se a novas necessidades e constantes exigências de uma sociedade em acelerada transformação. [COOMBS, 1969, p. 425]

Diferentemente do diagnóstico arendtiano - embora ambas as perspectivas partilhassem da constatação de transformações sociais ocorrendo para além dos limites educacionais -, a crise aí se consubstanciava como efeito de uma defasagem entre as ofertas por parte do sistema educacional e as demandas decorrentes de um mundo que se metamorfoseava. Tal descompasso se fez peça recorrente nos argumentos que sustentaram as várias constatações de uma crise em curso no âmbito educacional, as quais até hoje não cessaram de proliferar.

É evidente que não é sempre da mesma crise que se fala, já que essa denominação presta-se a identificar uma série de eventos de nuanças diversas, não obstante assim reunidos como peças de um fenômeno mais geral. Há quem refira uma crise no campo da cultura, como é o caso de Arendt; há quem alegue uma crise no campo educacional expandido; há quem se centre, ainda, em uma crise específica do sistema formal de ensino, como é o caso de Coombs. De todo modo, seja diretamente ou não, tais diagnósticos aqui considerados localizam efeitos específicos em torno das práticas educacionais.

Aproximando-nos do contexto brasileiro, Coombs engrossava um coro que aqui já era estridente naqueles meados do século XX. Entre os intelectuais nacionais engajados em tal argumentação, destacava-se Anísio Teixeira, para quem não era "difícil encontrar-se um relativo consenso de opinião a respeito da gravidade da situação educacional brasileira" [TEIXEIRA, 1953a, p. 20]. Por diversas vezes, o educador baiano corroborou o consenso de que a "crise educacional brasileira é, assim, um espectro da crise brasileira de readaptação institucional" [p. 27], evidenciando o fato de que, em sua análise, tratava-se de um problema pertinente sobretudo à instituição escolar, a ser aí também solucionado. 
Já o professor e futuro deputado Sólon Borges dos Reis [1953, p. 133] falava de um âmbito mais localizado, a respeito de "uma crise de crescimento que estaria afetando a organização pedagógica paulista", mas não hesitava em ampliar suas considerações e alertar para o que seria mais "um mal da época do que uma deficiência exclusivamente local" [p. 134]. Faria Góis Sobrinho [1958, p. 35], por sua vez, em discurso a universitários recémadmitidos na Universidade do Distrito Federal em 1957, conclamava a urgência de a formação superior comprometer-se a lidar com os efeitos de uma "evidente crise das elites brasileiras, que é bàsicamente uma crise de formação".

Ainda, no que se apresentava como uma continuação atualizada do Manifesto dos Pioneiros da Educação Nova de 1932, Fernando de Azevedo e demais signatários, 25 anos após o primeiro documento, punham-se a repensar suas proposições perante as novas condições sociais, marcadas por uma "fase crítica de reconstrução e de mudanças radicais" [AZEVEDO et al. 1959, p. 6], situação que alegavam ocasionar certa desintegração da educação pública.

Naquele novo manifesto, sublinhavam-se recorrentes acusações que à época pareciam voltar-se contra a configuração que o sistema educacional mantinha, o que também fica patente nas palavras de Lauro de Oliveira Lima [1960, p. 158], em palestra proferida em um curso de aperfeiçoamento de professores: "Cansou-se de dizer que a mocidade não quer aprender. Que a mocidade de hoje é refratária ao ensino. Que os alunos de hoje são diferentes dos de ontem". Semelhante alegação já se fazia presente alguns anos antes, na análise do professor Celso Kelly [1951, p. 162]: “A todo momento, há quem fale, a brados violentos, em 'decadência do ensino!' E todo esse enrolado de censuras, entre as legítimas e as exageradas, vem do povo até os departamentos de ensino, do leigo aos entendidos, das próprias escolas ao recinto dos parlamentares".

A lista de exemplos brasileiros subtraídos da década de 1950 poderia se estender, mas importa ressaltar que a resposta então ofertada a tal percepção generalizada de crise fosse ela identificada a partir das críticas voltadas ao sistema de ensino por parte da sociedade em geral, fosse materializada no diagnóstico de mazelas internas ao próprio sistema - era semelhante em todos aqueles diagnósticos: tarefa de primeira ordem, a escola demandava reforma. "Temos de reconstruir a escola brasileira para novas, instantes e mais altas necessidades nacionais, que já podem ser estudadas e conhecidas a ponto de indicarem por si mesmas os rumos a seguir”, declarava Anísio Teixeira [1953a, p. 42]. 
Mas embora aí desenhado com contornos da realidade nacional, o tema da crise educacional definitivamente nunca foi exclusividade do país. As obras de Arendt e Coombs, no mínimo, estavam ali para atestá-lo. No caso do autor estadunidense, sobretudo, o sustentáculo de suas análises também reverberou imediatamente por aqui.

Ao final do mesmo ano em que ocorreu a Conferência Internacional sobre a Crise Mundial da Educação (sediada no Estado da Virgínia, EUA, em outubro de 1967), evento que ensejaria o relatório produzido por Coombs, uma síntese do que lá se discutiu foi replicada e publicada no Brasil [RBEP, 1967a], juntamente com a informação de que Anísio Teixeira e Ulhôa Cintra (então Secretário de Educação do Estado de São Paulo) estiveram ali presentes, representando o país. No mesmo diapasão do livro de Coombs, o texto definia a crise nos seguintes termos:

Existe certamente uma crise na capacidade da educação para erguer seu rendimento até o ponto de corresponder às expectativas. Esta crise tem dois aspectos. O primeiro é a disparidade mundial existente entre as esperanças e a capacidade do próprio sistema educacional. O segundo é a disparidade ainda maior entre os países em desenvolvimento que se defrontam com extremas limitações de recursos totalmente inadequados e os países desenvolvidos, crescentemente preocupados com suas próprias necessidades internas. [RBEP, 1967a, p. 305]

Assumia-se o desarranjo educacional como problema de ordem mundial, propondose um plano de intervenção baseado na cooperação internacional. Afinal, concedia-se "ênfase ao fato de que a educação se tornou um empreendimento global - uma matéria de preocupação mútua e de mútua interdependência, que envolve literalmente tôdas as nações" [RBEP, 1967a, p. 312]. Vejamos em breve como se desenhava o referido plano de intervenção.

Antes, a fim de melhor perspectivar o assunto, vale ainda dedicar espaço a outras expressões do diagnóstico da crise que sucederam aquelas e que chegam até nossos dias.

Qualquer pessoa que se volte para o seu meio mais próximo, para as condições econômicas, sociais, morais e políticas do seu Estado, do Brasil e de todo o mundo contemporâneo, chegará fàcilmente à conclusão de que vivemos em uma época de crise. [MOREIRA, 1957b, p. 76]

É a coisa mais fácil do mundo declarar uma crise na educação: trata-se de uma condição praticamente endêmica. (BUCKMAN, 1973, p. 13)

Os aparelhos especializados e oficiais das transmissões organizadas de saberes encontram-se em crise. (BEILLEROT, 1985, p. 67) 
A educação também vive a sua crise, seja ela caracterizada pelos objetivos e finalidades de suas propostas, seja pelos seus procedimentos ou metodologias a serem seguidos. [GRINSPUN, 1994, p. 214]

Tendo-se afirmado, até meados da década de 70, como a única modalidade legítima de se pensar a educação, o modelo escolar parece sofrer neste final do século um processo de erosão especialmente intenso. (CORREIA; MATOS, 2001, p. 91)

Muito embora os discursos sobre a crise da educação escolar sejam tão antigos como a própria Escola, os factores supostamente geradores da actual crise são hoje mais amplos e heterogéneos. (AFONSO, 2002)

O sentimento generalizado e por vezes difuso de insatisfação que foi se instalando a partir do final da década de 1960, designado como uma "crise mundial da educação" deve, fundamentalmente, ser lido como uma crise da escola. (CANÁRIO, 2006, p. 11)

Entretanto, sabemos que a crise da escola encontra-se intrinsecamente ligada à própria crise social que, a partir dos anos 1980 do século anterior, adquire novas proporções, devido ao aceleramento do processo de globalização. [CHAVES, 2015]

Tendo em vista essa flagrante recorrência, José Mário Pires Azanha já no início dos anos 1990 tomou a alegação da crise como um dos temas de suas reflexões sobre a pesquisa educacional levada a cabo no Brasil. A partir da premissa de que tal situação "é demasiadamente visível para que possa ser negada até mesmo pelo leigo, pelo homem comum", Azanha (1990-1991, p. 65), de certo modo, também referia um desajuste no âmbito institucional formal, propondo um programa de pesquisa debruçado sobre a cultura escolar a fim de melhor compreender o que se passava no interior das escolas.

O autor paulistano, no entanto, não se dedicou a definir significados, causas ou soluções para a crise sobre a qual discorria. Em vez disso, defendeu a necessidade de se examinar o cotidiano escolar por meio de uma investigação descritiva que evitasse ajuizamentos abstracionistas apoiados tão somente nos enunciados correntes. Isso porque, para ele, "o simples reconhecimento da existência de uma crise na instituição da escola deveria antes nos conduzir a rever nossas idéias sobre ela do que, apressadamente, levar a esforços para reformá-la" (AZANHA, 1990-1991, p. 66).

Azanha reivindicava, assim, algum rigor científico no tratamento do assunto: perante um discurso que alegava crise, seria preciso entabular uma investigação empírica preocupada não com proposições a priori reformadoras, mas com um questionamento de ideias vigentes que, no limite, incluísse a própria noção de crise. Isso porque, em sua avaliação, “a 
banalidade da crise escolar tem um forte poder de banalização de nossas respostas a essa crise" (AZANHA, 1990-1991, p. 68).

Considerar a crise em sua condição de banalidade e defender a revisão de ideias a seu respeito já denota um posicionamento em tudo diverso de sua constatação como fenômeno extraordinário e irrefutável. Uma acepção afinada ao que Foucault (2012, p. 29) certa vez presumiu:

Penso ser preciso ter consciência de que, uma vez mais, a crise é uma espécie de acompanhamento teórico que os políticos, os economistas, os filósofos e alguns outros se propiciam, a fim de dar um status a um presente para o qual eles não têm um instrumento de análise. Se quiserem: a crise é o perpétuo presente. Nunca houve um momento da história ocidental moderna que não tenha tido a consciência bastante grave de uma crise vivamente experimentada, até mesmo no corpo das pessoas.

Ora, se há crise em todos os períodos da história da educação, ao menos no último século, quando teria havido alguma organicidade? Onde estaria o apogeu a ser reestabelecido? Se a crise é uma constante, então talvez seja preciso assumir que ela própria encarna a organicidade possível. Dando um passo além, poderíamos aventar uma função estratégica operando produtivamente no horizonte daquelas alegações. Nesse sentido, suporíamos que

[...] o discurso da crise intervém como método político de gestão das populações. A reestruturação permanente de tudo [...] é a única forma de organizar, por via de uma perturbação constante das condições de existência, a inexistência do partido adverso. A retórica da mudança serve para desmantelar qualquer hábito, quebrar quaisquer laços, desfazer qualquer evidência, dissuadir qualquer solidariedade, manter uma insegurança existencial crónica. Ela corresponde a uma estratégia que se formula nestes termos: "Prevenir, por via da crise permanente, toda e qualquer crise efetiva”. (COMITÉ INVISÍVEL, 2015, p. 19)

Se tais suspeitas forem plausíveis, será admissível reputar a ideia de crise não como fenômeno empírico a ser constatado pela tarefa analítica daqueles que se debruçam sobre determinada esfera social, tampouco como efeito colateral de um conjunto de transformações, mas como um objetivo permanentemente perseguido - com sua respectiva função performativa daquilo que supõe representar. Isso não equivale a dizer que a crise não existe; antes, que, independentemente de seu correlato factual, sua alegação se converte em demanda imediata por respostas, tal como previa Azanha. 
Com efeito, no prefácio à edição brasileira de seu livro, Coombs (1986, p. 15) advertia: "não temos o objetivo de provar a existência de um agravamento da crise educacional e dar o grito de alarme, mas sim procurar encontrar as causas da crise e sugerir possíveis instrumentos e estratégias que os países poderiam usar para vencer estes problemas básicos”. Tratava-se, em primeira instância, de oferecer respostas. E estas, diferentemente das que vimos ser apontadas pelos intelectuais brasileiros ao longo da década de 1950, não se centravam apenas na reformulação das instituições escolares. Antes, nutria-se o objetivo de

[...] criar um sistema de aprendizagem altamente diversificado, capaz de acompanhar o indivíduo durante toda a vida, no qual combinar-se-ão elementos formais, não-formais e informais, de maneira a proporcionar uma ampla variedade de opções de aprendizagem para todos os membros da população, independentemente de idade, sexo, ocupação ou posição social. (COOMBS, 1986, p. 16)

Fazendo coro ao que propusera Coombs, um novo relatório seria produzido em 1973, também sob anuência da UNESCO. Intitulado Aprender a ser e organizado pelo político francês Edgar Faure, o documento almejava lançar as bases para um conceito de educação renovado, fruto de um reposicionamento substancial dos sistemas de ensino:

[...] a partir de agora, o ensino poderá ser assegurado por outrem que não os funcionários especializados para este efeito; as divisórias verticais tendem a desaparecer; as relações de fronteira que existem entre o domínio da escola e o que se chamou escola paralela [...] não têm mais sentido. (FAURE et al., 1981, p. 249)

Era em favor de uma educação socialmente difusa, permanente ("pedra angular da política educativa" [RBEP, 1973b, p. 157]), e, ao mesmo tempo, em oposição ao monopólio da escola sobre os processos educativos, que tal proposta se desdobrava. Incluindo entre seus princípios a intenção de "prolongar a educação ao longo de toda a vida, sem limitá-la aos muros da escola", a comissão internacional de intelectuais presidida por Faure entendia, categoricamente, que "a educação é a vida e a vida é a educação" [RBEP, 1973b, p. 158].

O cenário de crise mundial enunciado na Conferência Internacional de 1967 e descrito por Coombs concretizava o lugar, doravante, de uma pronta resposta igualmente global: se o sistema formal apresentava-se inoperante - a crise aí referida, afinal, era uma crise do sistema formal de ensino -, a alternativa implicaria um espraiamento educativo para além de suas fronteiras institucionais. 
Contemporâneo aos dois diagnósticos propositivos elaborados sob a égide da UNESCO (COOMBS, 1987; FAURE, 1981), respectivamente em 1967/1968 e 1973, o projeto encabeçado por Ivan Illich e validado por Everett Reimer (1975) e Peter Buckman (1973), entre outros, trazia premissa semelhante - a crise educacional - e soluções análogas - a defesa de uma educação para além dos espaços e tempos escolares, embora na forma mais radical da desescolarização.

\subsection{A exterioridade institucional como remédio}

Não por acaso, no mesmo fascículo 134 da $R B E P$ em que se veiculou o texto de Illich [1974] intitulado Como educar sem escola?, seu livro Sociedade sem escolas foi resenhado ao lado de Aprender a ser, de Edgar Faure. Em bloco, a argumentação se adensava ainda mais. Da radical crítica illichiana à escolarização e seus efeitos [LIMA, 1974], passando pelos dados quantitativos produzidos pela UNESCO a respeito da inviabilidade da escola "perante os novos objetivos impostos à educação pela rápida transformação dos conhecimentos e das sociedades" [CARNEIRO, 1974, p. 279], a solução adquiria forma de sugestiva indagação: "Não disporá o mundo atual, que tanto exige da educação, de novos meios a que esta possa recorrer para não falhar em sua missão?" [CARNEIRO, 1974, p. 281].

Como vimos, a resposta já estava traçada. E naquela mesma edição de 1974 ela se enunciava indubitável nas palavras do autor inglês W. Kenneth Richmond, a partir de uma conferência internacional recém realizada em Nápoles sobre o tema da sociedade educativa:

\footnotetext{
É evidente que a aprendizagem não mais pode estar confinada às paredes da sala de aula, como também o próprio fato de que ela não termina no momento em que o estudante deixa a escola. A aprendizagem se realiza em grande variedade de ambientes: no lar, em grupos da mesma condição social, na igreja, no local de trabalho, na comunidade. Aprendizagem se inicia no momento do nascimento e só termina no momento da morte. $\mathrm{Na}$ sociedade educativa do futuro (diferentemente da atual sociedade escolarizada), a escola figurará, provavelmente, apenas como uma das muitas instituições responsáveis pela educação e bem-estar social, tanto de jovens como de adultos. [RICHMOND, 1974, p. 252, grifos nossos]
}

Uma edição inteira estava dedicada a propostas que questionavam a educação de então, segundo antecipava o editorial do número 134 da $R B E P$. A razão anunciada para tal 
seleção de textos residia na esperança de que "o processo educativo se torne cada vez mais função primordial da comunidade, toda ela comprometida no trabalho de formação humana [...]. Enfim, a educação assumida como tarefa de todos, a serviço de cada um" [RBEP, 1974, p. 125].

De algum modo, o prognóstico aí traçado encontraria sua efetividade, se considerarmos que hoje constituímos uma sociedade educativa do futuro comparativamente ao que se vislumbrou quase quatro décadas atrás, embora lá já houvesse traços semelhantes. Vejamos alguns indícios.

Até recentemente, o slogan do governo brasileiro encontrava seu mote na proposição de uma pátria educadora. ${ }^{5}$ São Paulo é uma cidade educadora. Outras 481 cidades ao redor do mundo também o são - com direito a certificado atestando tal status. ${ }^{6} \mathrm{O}$ horizonte da desescolarização apregoada por Illich ainda nutre explicitamente empreitadas diversas, a exemplo das ideias difundidas pela ex-bailarina Ana Thomaz, que se destaca como uma das gurus do assunto em solo brasileiro, servindo de inspiração a uma série de outros projetos. ${ }^{7}$

Para além do contexto nacional, nesta primeira década do século XXI, o jovem Logan LaPlante prega o que denomina hackschooling, ${ }^{8}$ enquanto Dale Stephens faz o mesmo em relação ao uncollege. ${ }^{9}$ Cada uma com suas particularidades, ambas as iniciativas margeiam o chamado homeschooling naquilo que essa modalidade tem de fazer oposição à educação escolarizada. Respectivamente, foram concebidas por dois jovens - um canadense em idade escolar (Logan LaPlante), o outro norte-americano já em nível universitário (Dale Stephens) - que passaram a divulgar os princípios de suas ideias em concorridas conferências e websites. No primeiro caso, utiliza-se de um neologismo que bem define algo que os dois têm em comum: trata-se de hackear a escola, produzindo alternativas educativas e formativas para além dos limites institucionais.

\footnotetext{
${ }^{5}$ Brasil, Pátria Educadora foi o lema do governo de Dilma Roussef a partir de 2015. Na ocasião de sua posse, a presidenta declarou: "Ao bradarmos 'Brasil, pátria educadora' estamos dizendo que a educação será a prioridade das prioridades, mas também que devemos buscar, em todas as ações do governo, um sentido formador, uma prática cidadã, um compromisso de ética e sentimento republicano" (Disponível em: <http://www.brasil.gov.br/governo/2015/01/dilma-toma-posse-e-anuncia-lema-do-novo-governo-201cbrasil-pa tria-educadora201d>. Acesso em: 31 ago. 2016). Em 31 de agosto de 2016, porém, seu mandato foi cassado e o lema, substituído por Governo Federal: Ordem e Progresso.

${ }^{6}$ Disponível em: <http://www.edcities.org/>. Acesso em: 31 ago. 2016.

${ }^{7}$ Disponível em: <https://www.youtube.com/watch?v=QveTf5DekIo>. Acesso em: 31 ago. 2016.

${ }^{8}$ Disponível em: <http://about.me/loganlaplante>. Acesso em: 31 ago. 2016.

${ }^{9}$ Disponível em: <http://www.uncollege.org/>. Acesso em: 31 ago. 2016.
} 
Os argumentos em prol de projetos como esses têm em comum, ainda, certo apreço pela eficácia daquilo que propõem; uma eficácia, dizem, superior ao que a escola é capaz de produzir em sua obsolescência. Trata-se, no interior dessas propostas, de aprimorar continuamente aquilo que se é - ou que se escolhe ser. Em outros termos, trata-se de empreender. Não por acaso, algumas das palavras de ordem que circulam em tais discursos são criatividade, autodesenvolvimento, empoderamento e inovação, entre outras, todas plenamente alinhadas ao paradigma do empreendedorismo e às tendências correntes de mercado.

Eis mais um pretexto para que a crise da escola venha à tona, sob a alegação de dissonância entre um modelo obsoleto e propostas em dia com as exigências do tempo. De um lado a outro, um mote comum: mais educação, de preferência fora dos muros escolares.

Ao utilizarem suas vivências autobiográficas como plano argumentativo em prol da desescolarização, LaPlante e Stephens atualizam uma estratégia já posta em prática na década de 1970 por Joe Ravetz (1973, p. 171), então definido em suas próprias palavras como "uma pessoa que está decepcionada e alienada diante do quadro escolar mas que quer continuar a sua 'educação' e por isso deixa voluntariamente a escola, após ter atingido a idade mínima em que é permitido abandoná-la”. Contemporâneo de Illich e anunciadamente adepto de suas propostas, Ravetz descreveu as escolhas e os desafios envolvidos em seu abandono da vida escolar, muitas vezes atravessado por "crises de insegurança e tentações de largar tudo" (p. 183). Sua conclusão, no entanto, era categórica àquele que se dispusesse a trilhar caminho semelhante: "a única coisa que você não terá muitas possibilidades de experimentar é o tédio; a estrada para a liberdade pode não ser fácil, mas é sempre interessante" (p. 183). Tratava-se, assim, de resistir à escola, tendo como destino último a liberdade.

Resistência e liberdade: mais duas plataformas comuns a Ivan Illich e Paulo Freire em suas respectivas proposições. Curioso é aperceber-se de que as soluções encontradas por quem se dispõe a seguir em seu encalço engendram, em geral, práticas que coincidem com disposições deveras difundidas, historicamente, no jargão científico, oficial e político voltado às questões educacionais. Que resistência e que liberdade são possíveis quando as estratégias vislumbradas encontram ressonância fácil nas preocupações com o controle, a ordem e o progresso de uma população? 
Um aspecto partilhado pelos três personagens desescolarizados - LaPlante, Stephens e Ravetz - deve, porém, chamar-nos a atenção: seus antecedentes escolarizados, uma vez que os três frequentaram anos de instrução formal, alfabetizaram-se e formaram-se no interior de currículos institucionalizados antes de se declararem avessos à escolarização. Ademais, provêm de regiões ocidentais, metropolitanas e supostamente privilegiadas, situadas em países plenamente escolarizados (respectivamente, Canadá, Estados Unidos e Reino Unido). Se se pretendem emblemáticos da bandeira da desescolarização, tais modelos revelam-se, pelo inverso, exemplos do próprio triunfo da escolarização. Uma vez mais, deparamos com a impossibilidade de se colocar fora de uma experiência no interior da qual se foi constituído.

É tempo, então, de examinar o que tem sido alardeado propriamente no campo conceitual das iniciativas educacionais não escolares, previstas tanto em projetos mais radicais como o illichiano, quanto naqueles que não chegam a defender o desmonte da instituição escolar, mas sim uma estrutura educacional que lhe seria complementar. Em primeiro lugar, vejamos como se situam as opções terminológicas.

Um simples levantamento de expressões relativas à expansão do intento educativo para além dos limites institucionais clássicos resulta em um profuso rol de definições que inclui, para citar alguns exemplos esparsos, educação não formal, educação informal, educação extraescolar, educação permanente, educação ao longo da vida, educação social, educação popular, cidade educadora, sociedade do conhecimento, sociedade da aprendizagem, entre outros. É evidente que há aí traços semânticos diversos e não necessariamente convergentes.

Enquanto alguns buscam classificar determinadas práticas conforme seu grau de formalização, uns têm caráter mais propositivo e outros se pretendem analíticos (até mesmo críticos) de determinados fenômenos. Nesse último caso, é possível encaixar expressões como sociedade do conhecimento e sociedade da aprendizagem; no anterior, cidade educadora, educação social, educação popular, educação permanente e educação ao longo da vida; já entre as expressões que buscam descrever níveis de formalização, alocaríamos, como é evidente, educação não formal e educação informal (acrescidas da educação formal, que, junto às outras duas, perfaz uma tríade conceitual). 
Quando se trata de definir a educação como formal, não formal ou informal, alguns consensos são facilmente identificáveis. A educação formal, em geral, é delimitada por um espaço institucional específico, por uma regulamentação explícita e por certa padronização via a presença de referenciais curriculares. O âmbito educativo não formal, por sua vez, é caracterizado como aquilo que se dá paralela ou externamente à instituição, em um processo ampliado que visa a certo tipo de aprendizado, seja de conteúdos também abordados pela escola (no caso da educação de jovens e adultos, por exemplo), seja de aspectos voltados à emancipação, à participação política, à capacitação para o trabalho técnico etc. (como ocorre com as organizações não governamentais atuantes no campo social). Os demais processos educativos - como a educação transmitida pelos pais aos seus filhos, pelo convívio com terceiros ou mesmo aquela involuntariamente recebida por meios culturais e midiáticos estariam incluídos sob a égide do informal (LA BELLE, 1982; AFONSO, 1989; GOHN, 2008, 2010; TRILLA BERNET, 2003, 2008).

Um importante aspecto apresentado como divisa entre tais categorias é o caráter intencional, a distinguir, de um lado, o formal e o não formal e, de outro, o informal. Nas palavras de Maria da Glória Gohn (2008, p. 99), estudiosa do assunto, “o que diferencia a educação não-formal da informal é que na primeira existe a intencionalidade [...]. A educação informal decorre de processos espontâneos ou naturais, ainda que seja carregada de valores e representações".

Jaume Trilla Bernet (2008), destacada referência a esse respeito, corrobora a classificação proposta por Gohn, mas, por julgar que a intencionalidade por si só não representa separação suficiente entre os três âmbitos, acrescenta dois outros critérios: a diferenciação e a especificidade da função educativa. Como decorrência, o campo genérico da educação vê-se partido em dois grandes grupos: o primeiro, constituído pelos âmbitos formal e não formal, estaria marcado pela intencionalidade, pela diferenciação e pela especificidade; o segundo, informal, consistiria em tudo aquilo que não se encaixa no primeiro.

Ora, pode-se supor que a preocupação em definir os limites entre as esferas formal, não formal e informal relacionar-se-ia, ela própria, a um incremento das ações não escolares, uma vez que a definição de tais categorias, longe de apenas designar fenômenos preexistentes, solidifica-os, englobando campos imprevistos de intervenção. Nesse sentido, afirmar que existem processos educativos não intencionais e denominá-los informais equivaleria a assumir que há uma função educativa desde sempre a eles atribuída. 
Como a esta altura já deve estar evidente, a escolha deste trabalho foi por utilizar a expressão mais genérica educação não escolar para designar os processos educativos exteriores à escola - decisão que se fez determinante, sobretudo, no modo como se efetivou a construção do arquivo empírico. A principal justificativa, a princípio, refere-se ao fato de que tal denominação era mais literalmente justa mediante o que se intentava analisar, evitando adentrar minúcias conceituais que incorriam no risco de fazer mais do que apenas atribuir um nome. Tratou-se tão somente de definir a distinção relativa ao tempo e ao espaço em que as práticas se efetuam. Nesse sentido, é preciso reconhecer que no interior da escola - de seu tempo e de seu espaço - também ocorrem os processos educativos reconhecidos como não formais e informais, mas não eram eles o alvo da análise, já que não diziam respeito a um espraiamento pedagógico no tecido social como um todo.

Outros autores compartilham de tal opção e apresentam justificativas que vale a pena acompanhar. Eliana Moura e Dinora Zucchetti [2006] argumentam, por exemplo, que a terminologia educação não formal não seria adequada porque diversas práticas educacionais não escolares são também formalizadas - ainda que detenham uma forma "bastante fluida, com contornos maleáveis”, conforme concordaria Margareth Park (2005, p. 68).

Segundo Moura e Zucchetti [2006, p. 231], “as práticas de educação não escolar parecem estar fixadas num Sistema tanto quanto a educação escolar, embora não componham o Sistema de Ensino”. Daí não ser válido classificá-las quanto a uma ausência de formalização. As mesmas autoras também afirmam que aquela denominação carregaria consigo, implicitamente, uma diferenciação de sujeitos aos quais tais práticas alvejam: entre quem tem pleno acesso à educação e à cultura formais e quem demanda serviços sociais entendidos por um viés assistencialista. A expressão educação não escolar, por sua vez, estaria menos impregnada de significados outros que não a simples exterioridade em relação à instituição escolar.

É por motivo semelhante que Marcos Francisco Martins (2016) sustenta sua equivalente preferência. Ao levar a cabo uma "pesquisa que procura identificar os fundamentos filosóficos das ações educativas não escolares” (p. 41), o autor compõe uma discussão terminológica e conceitual rara no campo dos estudos sobre as várias modalidades de educação não escolar. Em suas palavras, a expressão educação não escolar abrangeria "a totalidade dos processos educativos que se desdobram fora do sistema escolar” (p. 50), reunindo três condições favoráveis à opção por seu uso: o fato de identificar o que é realmente comum a essas práticas, sem se deter em especificidades; a contribuição que com 
isso oferece para que os pesquisadores não se percam em minúcias que não digam respeito ao fundamental dos fenômenos analisados; a contraposição que estabelece à ideia genérica de que a educação só ocorre no interior da escola.

Mas tal perspectiva não é consensual, já que há quem também se oponha à bipartição das modalidades educativas entre escolar e não escolar. É o caso de Maria da Glória Gohn, cuja definição para educação não formal vimos há pouco. A pesquisadora é incisiva em sua discordância, como se pode observar no excerto a seguir.

\begin{abstract}
Alguns autores teimam em denominar o aprendizado de conteúdos nãoescolares, em espaços associativos, movimentos sociais, ONGs etc. como sendo educação informal. Achamos que essa terminologia e classificação é incorreta, pois trabalha-se com um paradigma bipolar onde existe apenas dois tipos de aprendizagem: o escolar e o não-escolar. Tudo o que ocorre fora dos muros das escolas é pensado como aprendizagem não-escolar e perde seu caráter de educação propriamente dita. (GOHN, 2008, p. 100, grifos nossos)
\end{abstract}

Em sua compreensão, portanto, a menção a uma educação não escolar excluiria a gradação de formalização prevista na tríade formal, não formal e informal. É, de novo, a perspectiva da intencionalidade que parece embasar seu argumento, já que ela acarretaria uma diferenciação inequívoca entre as práticas educativas exteriores à instituição escolar. Nesse diapasão, seria necessária a ascensão a um estatuto intencional para que uma prática se tornasse, enfim, ocasião de aprendizagem.

Para além dos imbróglios terminológicos, a gênese da educação não formal poderia ser disposta em dois planos, de acordo com Trilla Bernet (1999, p. 199, tradução nossa):

[...] o de uma realidade que foi gerando novas necessidades educativas que devem ser satisfeitas por instituições e meios distintos dos propriamente escolares; e o de um discurso pedagógico que elabora teorias e cria conceitos novos para dar conta dessa expansão e diversificação do universo educativo.

Tal duplicidade parece sintetizar a relação direta entre uma acirrada demanda sóciohistórica e uma possível resposta teórico-prática, sendo a primeira produzida como consequência de uma suposta insuficiência da escola em face das necessidades educativas mais amplas. Em outros termos: crise educacional e as respostas a ela ofertadas, uma vez mais. 
O posicionamento de Trilla Bernet (1999) reitera um raciocínio em geral partilhado pelos pesquisadores da educação não formal: justifica-se a expansão do campo pedagógico pela própria expansão do objeto sobre o qual ele incide, segundo uma relação direta de causa e efeito. Mostra exemplar desse movimento é a proposição de Almerindo Janela Afonso (1989) concernente à necessidade de se desenvolver uma área de conhecimento especificamente dedicada às práticas educativas exteriores à escola, que viriam ganhando vulto empírico: a sociologia da educação não escolar.

Conforme nos alerta Alfredo Veiga-Neto (2004, p. 65), porém, o "conjunto de saberes que se reúnem sob a denominação de Pedagogia não é algo natural, algo que esteja aí no mundo e que tenha sido descoberto pela razão humana". Antes, como toda disciplina, a pedagogia - ou a sociologia, no caso de Afonso (1989) - também engendra seus objetos, que passam a existir de determinados modos após serem performativamente investidos pelos saberes que os descrevem.

Para Foucault, seguindo as pistas deixadas por Nietzsche, não há "nenhuma semelhança, nenhuma afinidade prévia entre conhecimento e essas coisas que seria necessário conhecer" (FOUCAULT, 2008a, p. 17). Nesse sentido, ao efetuar a crítica das evidências e investigar as relações de poder intrínsecas a todo saber, o pensador francês traz à baila duas premissas cruciais: a arbitrariedade dos signos em relação às coisas do mundo e a capacidade produtiva dos aparatos discursivos. Tais premissas, conforme propõe ele, relacionar-se-iam-se da seguinte forma: se, por um lado, a correlação entre a linguagem e a coisa designada é frágil e arbitrária, por outro, uma vinculação entre elas fundar-se-ia no momento em que algo se enuncia. Ou seja, não se trata de dizer que inexiste qualquer vínculo entre uma coisa e outra, mas que inexiste uma relação prévia, essencial. Assim, a correspondência seria forjada, produzida por meio da linguagem. Daí o caráter performativo do conhecimento e, no caso em pauta, do campo pedagógico, cuja expansão de domínios deve ser pensada como também produtora de efeitos de realidade.

É o que podemos observar, por exemplo, nos efeitos derivados das várias alegações de uma crise educacional em curso, efeitos estes consubstanciados nas soluções que historicamente foram sendo ofertadas. Afinal, se a crise pode ser assumida como objeto produzido no interior de um discurso, também o são as respostas a ela correspondentes.

Enquanto a crise educacional era constatada por alguns, por outros ela era também visada, até mesmo cultivada. Tal é o caso de Illich, como já visto, que não apenas 
identificava um cenário crítico iminente, mas propugnava sua intensificação, via a defesa de uma desinstalação definitiva do aparato escolar que permeava o tecido social.

Na sequência de seus argumentos, Illich criticava os movimentos que, diante da crise escolar, propunham novos formatos de escolas, pretensamente melhores. Para ele, assim se mantinha um currículo oculto subjacente à própria estrutura escolarizada e constituído por elementos como obrigação de frequência, idade escolar, gestão pelos professores, graduação do programa, certificação com valor fora da escola e, enfim, monopólio do sistema escolar sobre as aprendizagens.

No entanto, quando denunciava a manutenção de um currículo oculto nas várias proposições de uma educação mais libertadora que não renunciavam à escola, Illich talvez ignorasse que também a desescolarização traria consigo um currículo, provavelmente ainda mais oculto, uma vez que supostamente desligado da submissão a uma estrutura institucional. É o que aponta Bártolo Paiva Campos (1976) em sua leitura crítica da defesa de Illich no sentido de uma centralidade das escolhas individuais. Nas palavras do autor:

Illich esquece, todavia, que essa autonomia não é dada, mas tem de se conquistar, e isso passando pelos caminhos impostos por outros e defrontando as suas exigências. Por vezes seríamos levados a crer que ele pensa que cada indivíduo tem em si uma vocação inata que não exige senão espaço para se desenvolver; seríamos levados a crer que ele esquece o lugar da cultura (civilização) na constituição do homem. (CAMPOS, 1976, p. 79)

O que se vê aí em embate, de novo, é a oposição entre dois polos daquele par argumentativo bastante presente quando se trata das formulações dedicadas à definição de âmbitos educativos formais, não formais e informais: a espontaneidade versus a intencionalidade. Tal oposição também se fazia notar mesmo antes de a educação não escolar tornar-se uma temática de relevo ao campo pedagógico.

Em 1944, no primeiro texto que se oferecia aos leitores da edição inaugural da RBEP, Lourenço Filho dispôs-se a discutir a educação como um problema nacional. Se, de acordo com ele, a educação não se define independentemente do contexto em que ocorre, também no plano da Nação ela deveria ser um empreendimento dotado de contornos específicos. "Espontânea e difusa, a princípio; intencional e sistematizada depois" [LOURENÇO FILHO, 1944a, p. 8], ela equivaleria a um processo regulador dos valores a partir das condições sociais impostas a cada momento. Nesse mesmo viés, a formação de um espírito nacional 
tomaria forma quando "forças espontâneas de coesão do grupo social" dessem lugar a uma “verdadeira 'consciência' do processo educativo" (p. 9).

Intencional e verdadeira consciência aparecem aí cumprindo funções semânticas correspondentes e centrais na argumentação de Lourenço Filho. Denotam o surgimento de uma intencionalidade e de uma consciência capazes de oferecer coesão a tendências educativas e gregárias que seriam próprias - e espontâneas - à vida social.

Embora Lourenço Filho àquela época estivesse preocupado sobretudo com âmbitos educativos institucionais, sua observação se dá na mesma direção do que pondera Trilla Bernet (1999), para quem haveria dois níveis de significação, por exemplo, na proposição de uma cidade educadora: de um lado, o nível descritivo, que evidencia o fato de que todas as cidades educam, espontaneamente; de outro, o nível propositivo, marcado pela formulação de que as cidades devem educar, intencionalmente. Daí o autor, assim como Illich, também afirmar a existência de um currículo oculto em vigor no ambiente urbano, currículo este formado por "elementos de cultura, formas de vida, normas e atitudes sociais, valores, tradições, costumes, expectativas, desejos" (TRILLA BERNET, 1999, p. 217, tradução nossa). A passagem da dimensão descritiva à propositiva dar-se-ia por meio da transformação do "currículo implícito num currículo desejável" (p. 218, tradução nossa), ou seja, por meio da assunção intencional daquilo que operava de maneira supostamente espontânea.

Vale advertir, ademais, que opor um currículo desejável a um currículo implícito (ou oculto) equivale a conceber que haveria tendências formativas em curso que deveriam ser extirpadas e substituídas por outras mais adequadas. Pode-se falar, por extensão de sentido, em intencionalidades negativas e positivas - ou formativas e deformativas. Haveria algo a ser tolhido das práticas sociais e cambiado por aquilo que seria desejável, conforme as expectativas educacionais adotadas. Tal oposição é recorrente nos escritos sobre o assunto veiculados nas últimas décadas, como veremos mais adiante.

Ora, imbuir determinadas práticas de intencionalidade educativa significa investi-las de um currículo determinado. Afinal, a educação não é sempre concebida do mesmo modo, mas sim a partir do discurso de seu tempo. Um pacote de verdades e valores, enfim, acossa intrinsecamente a intencionalidade pretendida. No caso da cidade educadora descrita por Trilla Bernet, pode-se dizer que ela "é chamada a adquirir uma intencionalidade com vistas à produção de um sujeito citadino específico, conformado ao funcionamento do meio que 
habita aos moldes de um aluno obediente, engajado e responsável" [VIEIRA; AQUINO, 2015, p. 322].

Nessa linha argumentativa que vai de Lourenço Filho a Trilla Bernet, passando por Illich, uma série de outros autores poderia ser alocada, sobretudo a partir das fontes empíricas analisadas, mas também fora delas. Na maioria dos casos, é também possível reconhecer um desfecho argumentativo comum: trata-se sempre de, uma vez constatado terreno à sua efetivação, direcionar tais intencionalidades a propósitos determinados.

Que a oposição entre espontaneidade e intencionalidade seja questão para o campo da educação, isso não é novidade absoluta. No entanto, a recorrência do argumento em favor de fornecer justificativa e operacionalidade à investida sem rédeas dos intentos educativos não escolares acabou por colocar tal problemática ainda mais em relevo.

Illich (1977, p. 38) bem ilustra tal primado: “A maior parte da aprendizagem ocorre casualmente e, mesmo, a maior parte da aprendizagem intencional não é resultado de uma instrução programada". Também do punho do autor austríaco provém uma passagem digna de destaque: "Radical alternativa para uma sociedade desescolarizada exige não apenas novos e formais mecanismos para a aquisição formal de habilidades e sua aplicação educacional, mas implica novo enfoque da educação incidental ou informal” (ILLICH, 1977, p. 52).

Paulo Freire, por sua vez, fazendo a crítica daquilo que denominava educação bancária, apontava o caráter de dominação ideológica das relações educativas vigentes na forma escolar de então, motivo pelo qual voltava seu olhar para uma educação libertadora a ser efetivada no ambiente social mais amplo. Com efeito, segundo António Nóvoa (1998, p. 177), a “pedagogia de Freire não se esgota no 'educativo' e, menos ainda, no 'escolar'. Fortemente ideológica, projecta-se sempre no campo social e político”. Assim, pode-se dizer, por exemplo, que a obra Pedagogia do oprimido pôs em curso o "desafio de repensar a escola a partir do exterior, pelo menos do ponto de vista reflexivo" (PALHARES, 2009, p. 63), tornando-se referência capital a boa parte do que posteriormente foi discutido a esse respeito.

Tanto no caso de Illich quanto no de Freire, suas decorrentes proposições justificarse-iam, em maior ou menor grau, pela idealização de um mundo onde tudo fosse potencialmente educativo - o que guarda notável proximidade com aquilo que se observava nos relatórios de Coombs (1986) e de Faure (1981). Da crise educacional, constatada ou proclamada, derivaria, assim, o sonho de uma educação renovada, integral, irradiada para 
além das fronteiras e dos afazeres escolares. Supõe-se, ainda, que educativos seriam, de largada, os contextos não escolares - "Há uma pedagogicidade indiscutível na materialidade do espaço", apontava Freire (1999, p. 49) -, devendo eles apenas ser imbuídos de uma intencionalidade pedagógica.

Do que foi até aqui exposto, evidencia-se uma sequência argumentativa, em três patamares consecutivos: 1) crise educacional, tão constatada quanto intencionada; 2) espraiamento educativo não escolar; 3) intencionalidade pedagogizante rumo a processos considerados informais. Embora tal sequência possa agora parecer óbvia, é preciso admitir que ela nem sempre o foi.

Situação bastante distinta é flagrada entre os já referidos intelectuais brasileiros que veicularam suas discussões educacionais na RBEP ao longo da década de 1950, como se viu. Anísio Teixeira [1953a], por exemplo, detectava uma crise educacional no país, sem apelar, contudo, à exterioridade escolar como possível locus de superação dos entraves de então. Ao contrário, a solução por ele proposta conclamava justamente uma reforma da instituição escolar a fim de que esta se ajustasse às novas demandas que a ela se impunham historicamente. Não por acaso, Teixeira foi figura central no movimento da Escola Nova, e em seus escritos são recorrentes expressões como readaptação institucional e reconstrução da escola.

O que aqui se pretende sublinhar é o caráter arbitrário e não natural da tríade argumentativa há pouco apresentada. Ora, que haja um discurso sobre a crise educacional, isso não significa que uma crise factual o anteceda, tampouco implica uma derivação direta na ideia de que o campo pedagógico deveria voltar seus olhos para processos educativos situados no exterior escolar. Não é óbvio que a pedagogia tente recontextualizar-se perante as alegadas transformações da sociedade, propondo-se a incorporar novos objetos em seu domínio. Afinal, ela poderia, como efeito, reduzir-se, retrair suas fronteiras, mas não parece ser isso o que ocorre.

Apesar de não evidentes, entretanto, tais relações não deixaram de se produzir continuamente e de forjar efeitos descontínuos. Como resultado, o campo pedagógico viu-se fortalecer tanto no que diz respeito à incorporação de novos domínios de saber, quanto no que tange ao exercício de múltiplas possibilidades de intervenção para além do escopo escolar. 
A questão é abordada por Julio Groppa Aquino (2012) em termos de um duplo movimento presente no universo escolar: disjunção e dispersão. O primeiro eixo referir-se-ia a uma polivalência de funções hoje atribuídas à escola e aos profissionais que a ocupam, funções estas derivadas de exigências das mais variadas instâncias sociais e responsáveis por saturar o escopo de atuação daquela instituição, redundando em um efeito disjuntivo entre as demandas sociais e as respostas institucionais a elas oferecidas. No segundo eixo situa-se o fenômeno descrito como um "espraiamento sem precedentes de práticas de teor pedagogizante, não mais circunscritas ao espaço escolar" (AQUINO, 2012, p. 148). De um lado e de outro, o que se vê é certa permeabilidade das práticas educacionais, seja no sentido de incorporar novas preocupações aos seus domínios, seja na investida tentacular de multiplicação rumo a outros espaços e outras instâncias de ação.

\subsection{Efeitos nada colaterais}

Do diagnóstico da crise à proposição de soluções, os efeitos foram retumbantes. E exerceram-se no campo social como um todo, é certo, mas fizeram deslocar práticas e enunciados sobretudo no interior das esferas da educação, da pedagogia, da escola: essas instâncias movediças, difusas e já conceituadas à exaustão, que muitas vezes se fundem até não sabermos onde acaba uma e onde começa outra.

Se não nos interessa, ao menos por ora, adentrar o debate específico sobre suas respectivas definições, é porque o mote de nossa atenção centra-se nos movimentos que lhes são correlatos a partir dos aludidos efeitos, conforme a leitura de um conjunto heterogêneo de autores também preocupados com o estatuto educacional de suas épocas. Nesse sentido, a cada uma daquelas instâncias haveria uma derivação correspondente à sua dilatação no contemporâneo: educacionalização, pedagogização, escolarização. Embora os movimentos aí indicados pareçam apontar para uma mesma direção, as nuanças são de variadas ordens.

O terceiro deles - escolarização - talvez seja o que mais remeta a um campo unívoco de acepções, já que coincidiria com a institucionalização de determinadas práticas educativas no interior de um contexto delimitado de atuação, correspondendo à produção histórica do 
que se convencionou denominar educação escolar. A esse respeito, sobejam referências, mas é ponto pacífico que a instituição escolar que hoje conhecemos tem surgimento datado e recente na história humana. Quando se fala em escolarização, porém, não se trata apenas do advento de tal instituição, mas da absorção da tarefa educativa como prerrogativa a ela reservada.

Pode-se dizer, de modo geral, que a Modernidade atribuiu-se o objetivo de escolarização universal e formal. No período que intermedeia a Renascença e o Iluminismo, vemos delinear-se cada vez mais explicitamente um discurso humanista que acabou por se vincular a uma mudança de posicionamento em relação aos processos educativos. Tal olhar voltado para o homem - suas origens e vicissitudes - demandava, então, não apenas a consideração de uma essência previamente estabelecida, mas um trabalho que visasse à constituição de um indivíduo de acordo com certos moldes.

No bojo de tal movimento, destacam-se algumas concepções de educação em pauta nos primórdios do processo de formalização escolar. Erasmo de Rotterdam (1466-1536), Martinho Lutero (1483-1546), Michel de Montaigne (1533-1592) e Jan Amos Comenius (1592-1670) são alguns dos autores cujas obras prestam-se a uma análise profícua a esse respeito. Desconsideradas suas peculiaridades, nelas há em comum o que se poderia definir como sendo a defesa de uma educação formal, universal e institucionalizada - não na acepção precisa que esses termos adquirem hoje, certamente, mas em contraste com aquilo que se passava na sociedade europeia de então: uma educação nada padronizada, mormente moral, religiosa e familiar, além de diretamente vinculada a prerrogativas de classe.

Em sua análise dos primórdios da estrutura colégio que, de certa forma, viria a vingar até os dias de hoje, André Petitat (1994) afirma que, embora as instituições educativas datem de um passado muito mais distante, pode-se dizer que foi na forma colegial que elas atingiram seu ápice e sua configuração áurea. Não à toa, Petitat (1994, p. 76) assevera: "No período que se estende da Renascença às vésperas da Revolução Industrial, a criação e a multiplicação dos colégios constitui o fenômeno mais marcante da história das instituições escolares". Isso porque, entre outros aspectos envolvidos nessa racionalização das relações escolares, conforme as palavras do autor - ou formalização, para utilizar um termo mais afinado à presente discussão -, tal fenômeno envolveu não apenas uma transformação no modo de funcionamento daquelas instituições, mas também no modo de vida dos sujeitos que constituíam sua clientela. Educar formalmente significava ter como alvo não apenas o 
ensino e a transmissão de saberes, mas a modulação de uma internalização cultural, de um modo de ser.

Daí porque, quanto à sua forja, há quem defina a escolarização moderna como um processo fundamentalmente sustentado no desenvolvimento de tecnologias disciplinares (FOUCAULT, 2009). Entretanto, para além da escolarização ocorrida no nascimento da instituição escolar, a mesma expressão vem hoje sendo utilizada para descrever também a expansão de uma forma escolar cuja efetivação já seria independente da própria instituição. Nesse mesmo rastro, seria possível identificar sua configuração mais recente com um processo amplo de globalização e civilização cidadã (DEACON; PARKER, 1998) [VEIGA, 2002]. Vejamos alguns cenários que o ilustram.

Na região de Ladakh, ao sudeste da Ásia, alguns jovens frequentam uma escola de currículo britânico, que é das poucas instituições educacionais ali existentes. Apesar de a maioria de seus conterrâneos falar o dialeto tibetano ladakhi e viver da agricultura local, tais estudantes estão acostumados a se comunicar em inglês e sonham com o futuro em uma grande metrópole. São expostos a culturas e a saberes até então desconhecidos pelas gerações mais velhas de Ladakh. Tal é o contexto apresentado no provocativo documentário Escolarizando o mundo, ${ }^{10}$ lançado no ano de 2010.

Os pais e avós desses jovens ladakhianos não frequentaram a escola, uma vez que até há poucos anos não havia ali uma instituição assim classificável. Um dos argumentos do documentário desenrola-se justamente a partir daí: o mundo atual quer que eles estudem, sob a alegação de que seria preciso extirpar crenças e superstições infundadas e dar lugar à apropriação de conhecimentos científicos e validados nos dias de hoje. Ladakh deve atualizar-se, inserir-se no tempo em que vive. Política de inclusão da melhor definição, pois.

A partir do momento em que vão para a escola, os ladakhianos passam a viver de forma distinta do que antes eram os modos de vida predominantes na região. Seus conhecimentos, suas ambições, suas expectativas são outras; sua concepção acerca do próprio lugar que habitam já não é mais a mesma daqueles que ali viveram em condições diversas. Nesta direção segue a incisiva crítica tecida pelo documentário: a entrada da escola em uma tal comunidade mais seria uma violação, uma imposição fadada a destruir uma

\footnotetext{
${ }^{10}$ Título original: Schooling the world. Disponível em: 〈https://www.youtube.com/watch?v=7xqUKELDBqg>. Acesso em: 31 ago. 2016.
} 
cultura milenar em nome de ali estabelecer certa padronização ocidentalizada de hábitos, relações e anseios via educação escolar.

Em sua crítica à escolarização, o documentário abre margem para que se pense que o problema estaria na expansão da própria escola, em sua tentacularização rumo a outros espaços onde ela antes não se fazia assim presente. No entanto, arrisquemo-nos a pensar que esse processo está em curso mesmo onde não há escola, pois que ele já a ultrapassou, embora sua base derive basicamente de uma lógica escolar. Ou de uma forma escolar, como têm preferido referir autores como Guy Vincent, Bernard Lahire e Daniel Thin (2001).

Na esteira dessa formulação, vejamos:

Curiosamente esta percepção crescente de uma crise da instituição escolar acontece num período em que se assiste a uma crescente "predominância da forma escolar" (Vincent et al., 1994) nos processos de socialização, o que [...] significa verificarem-se: práticas sociais distintas; espaços e tempos didácticos próprios; representação e planificação do acto de aprendizagem como prática social com intencionalidade educativa manifesta; lógicas de trabalho e de reconhecimento de excelência próprios (ROTHES, 2009, p. 152).

O mesmo autor prossegue o argumento afirmando que a "extensão da forma escolar resulta ainda daquilo que vem sendo designado por uma 'pedagogização do social', ou seja, a tendência para encarar as questões sociais como problemas que são passíveis de soluções pedagógicas" (ROTHES, 2009, p. 155). A noção de forma escolar aí formulada em muito se coaduna com o que aqui vem sendo exposto: relaciona-se a uma crise da instituição escolar; está em crescente predominância; aplica-se ao meio social mais amplo e para além da escola; estaria acompanhada da tendência de se oferecerem soluções pedagógicas a questões que de outro modo não seriam assim encaradas.

Ainda a respeito do documentário, vale ressaltar que não é sem perplexidade que os nativos ladakhianos mais velhos encaram a empreitada da escolarização que acomete os mais jovens de seu povo. Diversas são as declarações expostas no filme quanto a tal insatisfação. Ao que somos levados a crer, prefeririam eles que seus filhos e netos permanecessem inseridos na sequência de transmissão cultural e trabalho ali perpetuada há tantas gerações. Ao escolar, prefeririam um não escolar, portanto. Mas um não escolar em tudo distinto do que é apregoado pelos hackers ocidentais há pouco mencionados e do que hoje se prolifera em sociedades já há tempos escolarizadas, uma vez que o primeiro está aquém da influência 
da escola, é anterior a ela, ao passo que o segundo é fruto dela própria. Ainda assim, os dois casos demostram o sucesso de tal empreitada segundo um princípio de inversão: o primeiro não pode mais existir após a chegada da escola; o segundo, por sua vez, só assim tem sua possibilidade de existência.

Nesse sentido, pode-se imaginar que, uma vez formulada, a crítica do documentário apenas acabaria por produzir em seus espectadores (escolarizados) uma reação de mais educação (quando não de abstenção absoluta): então iriam engajados e bem-intencionados cidadãos tentar entender os processos pelos quais os conhecimentos nativos de uma tal comunidade foram durante séculos transmitidos entre gerações, para que se pudesse agora garantir formas autênticas de reinserir as novas gerações naquele modelo tradicional. É o que se passa em casos semelhantes relativos a populações indígenas e rurais, tradicionalmente alheias ao aparato escolar próprio dos meios urbanos.

Ainda que sob a égide do não escolar, a solução aí prevista denota o triunfo da escolarização nos espaços em que ela se efetivou. Por ora, fiquemos com a hipótese de que, talvez, a maior mostra de tal triunfo seja justamente o fato de que a instituição escolar parece não mais ser necessária para que os modos de vida nela forjados multipliquem-se em seu exterior.

Entre variadas outras análises do assunto, porém, não são raros os que declaram a marcha de decadência progressiva da escola, ou ao menos sua complementação por processos que aparentemente iriam na direção inversa a uma institucionalização das práticas educativas. Eis, nesse último caso, o contexto que vem dando margem às designações de educacionalização e pedagogização. ${ }^{11}$

\footnotetext{
${ }^{11} \mathrm{O}$ termo pedagogização também é utilizado, por alguns autores, para caracterizar um processo coincidente com a escolarização moderna. É nesse sentido, por exemplo, que Julia Varela (1994) e Basil Bernstein [2003] referem-se a uma pedagogização do conhecimento, o que teria a ver, respectivamente, com a formalização de práticas educativas no interior de instituições escolares a partir do Renascimento e com a estruturação social do discurso pedagógico. Trata-se aí, em ambos os casos, de uma pedagogização referida à própria instituição histórica da escola e do discurso pedagógico. Cynthia Greive Veiga [2002, p. 99], em um movimento inverso, denomina pedagogização o estatuto educacional anterior à escolarização, afirmando que a "grande revolução do século XIX foi exatamente a substituição da pedagogização das relações sociais pela escolarização". Embora o termo empregado seja o mesmo, porém, ele não é utilizado, em tais análises, para designar o cerne dos processos que interessa aqui discutir.
} 
O autor francês Jacky Beillerot (1985) descreve os contornos de um cenário inusitado à primeira vista, mas talvez não mais surpreendente a esta altura de nossa discussão. A partir de uma série de levantamentos e cálculos referentes ao cotidiano de seu país à época em que escreve - início da década de 1980 -, ele é categórico ao afirmar que mais tempo era dispendido com ações pedagógicas do que na produção de bens e serviços. A conclusão parecia-lhe inequívoca: "A seguir ao sono, a pedagogia é a primeira atividade da nossa sociedade" (BEILLEROT, 1985, p. 36). Mais um, portanto, a afiançar o inflacionamento pedagógico que nos seria coetâneo, fenômeno então tomado como fato social e analisado sob a égide do que Beillerot (1985) denominou sociedade pedagógica - exaustivamente descrita pelo autor em livro homônimo dedicado ao tema.

De modo geral, ele se refere à crescente "introdução da relação pedagógica nas funções e papéis que dela estavam isentos", procurando explicitar a "transformação de atividades privadas ou sócias em atividades cujo conteúdo é cada vez mais de teor pedagógico" (BEILLEROT, 1985, p. 13). Assim, por meio de uma recolha minuciosa que vai desde enunciados dispersos na literatura, passando por dados e observações acerca dos âmbitos da vida privada, social, profissional, familiar, econômica, cultural e religiosa, até um arrazoado crítico sobre o papel ocupado pelo saber nas sociedades capitalistas, traçam-se ali muitas das premissas que também mobilizaram a presente investigação.

A despeito dos ecos encontrados, entretanto, faz-se necessário estabelecer algumas importantes ressalvas à análise tecida por Beillerot, quando considerada na perspectiva aqui empregada. Ressalvas, vale dizer, menos relativas ao cenário esboçado do que aos fundamentos que ele aponta em sua justificativa para a ocorrência de uma tal pedagogização.

A certa altura de suas ponderações, o autor interroga:

Porque motivo há mais pedagogia (escolar e não-escolar)? Porque motivo se pedagogizam as relações sociais (familiares, religiosas, de dominação, de exploração, etc.)? Porque pode a acção pedagógica ter uma autonomia relativa, ao ponto de se encontrar em regimes políticos diversos? (BEILLEROT, 1985, p. 89)

Em um esforço de síntese das várias ideias discutidas na sequência, pode-se dizer que as respostas por ele apresentadas desenrolam-se, basicamente, a reboque de duas linhas argumentativas. Na primeira delas, a pedagogia é pensada como via de transmissão de saberes, sendo estes, por sua vez, esmiuçados em sua participação nas forças produtivas de uma sociedade regida pela lógica do capital. Daí o reconhecimento de uma função 
reprodutora - e mantenedora - de desigualdades sociais e de privilégios de classe. Uma função fundamentalmente afinada, por conseguinte, às forças de reprodução ideológica, o que se explicita na asserção de que "a acção pedagógica faz papel de cimento ideológico e, logo, de pintura enganadora que permite furtar-se a tentativas de a pôr em causa" (BEILLEROT, 1985, p. 207).

Por extensão do argumento, Beillerot faz uma leitura centrada basicamente na ascendência estatal como fonte da qual emanariam os interesses de controle a serem correspondidos pela via pedagógica. Em suas palavras,

[...] o paradoxo é que nas sociedades cada vez mais caracterizadas pela importância do Estado, a pedagogização surge como um antídoto capaz de fazer esquecer a monstruosidade das intervenções e quadrículas do Estado. No entanto!... O Estado está no centro do processo de massificaçãoindividualização; tira proveito dos processos de pedagogização, igualmente porque a pedagogia se institucionaliza e porque ela se difunde de modo "selvagem"; trata-se sempre de explicar, de dar razão e, no fim de contas, de justificar as normas, de as compreender, de as admitir. (BEILLEROT, 1985, p. 205)

Tal entendimento dará lugar, um pouco adiante, à taxativa afirmação: "Ensina-se e aprende-se para acreditar e servir" (BEILLEROT, 1985, p. 211).

Enquanto a primeira resposta de Beillerot à indagação pelos motivos da pedagogização atual aparece sustentada em aspectos socioeconômicos, a segunda é desenvolvida em termos psicossociais, mais propriamente psicanalíticos: o autor lança mão do conceito freudiano de pulsão epistemofílica - dito de outro modo, desejo de saber. Combinando-se as duas respostas ofertadas, tudo se resumiria a um fenômeno da ordem da dominação. Para Beillerot (1985, p. 154), “o desejo de ensinar é filho do desejo de sedução. Ensinar é seduzir, forma de influenciar, que se distingue da imposição, mas cujo fim continua a ser o dominar".

Se é sobretudo na companhia de Michel Foucault que a presente investigação pretende prosseguir, é tempo de abrir espaço a um breve recuo conceitual que estabeleça, desde já, algumas das bases de pensamento com as quais se está a operar. Bases, neste caso, que nos impõem a recusa às noções de ideologia (na acepção que coincide com o uso que dela faz Beillerot) e dominação - intimamente atreladas uma à outra - como categorias explicativas dadas de antemão. Respectivamente, elas nos conduzem às teorizações 
desenvolvidas por Foucault em torno da verdade e do poder, que aliás estão no cerne de todo o seu pensamento.

Das várias abordagens possíveis - e já esgotadas por outros pesquisadores - às divergências aí em questão, centremo-nos especificamente na relação que há no interior desses pares conceituais. Entre ideologia e dominação, trata-se de um nexo fundado na ocultação de uma suposta verdade essencial a fim de sustentar a legitimidade de um poder dominante. A exemplo do que sublinha Beillerot (1985, p. 205), a pedagogização atuaria ideologicamente ao encobrir "a monstruosidade das intervenções e quadrículas do Estado".

Já para Foucault (2005, p. 7), o que interessa são "os efeitos de verdade no interior de discursos que não são nem verdadeiros e nem falsos", sempre pensados conforme uma acepção de poder que “designa relações entre 'parceiros' (entendendo-se por isto [...] um conjunto de ações que se induzem e se respondem umas às outras)" (FOUCAULT, 2010b, p. 284). Não haveria, nesse sentido, uma verdade primeira aderida à realidade a se conhecer ou ocultar, mas sim políticas de verdade forjadas nas próprias relações de poder - jogos de veridicção, mais precisamente. Em vez de pensar a relação do sujeito com a verdade em termos de um falseamento ideológico - uma perspectiva metafísica do discurso -, falaríamos em processos de subjetivação atravessados por uma relação de imanência com o verdadeiro. Supõe-se, nessa medida, um sujeito ativo no interior das produções que engendra e que o engendram, o que nos convoca diretamente na condição de agentes de tais processos, e não de seus cativos.

Ainda, como vimos, a tópica do desejo seria, para Beillerot (1985), a brecha subjetiva que possibilitaria a vinculação de toda uma população aos mecanismos de dominação pela via pedagogizante. Um encaixe bastante bem-sucedido, de fato, se compartilhássemos de tais pressupostos: de um lado, uma intencionalidade dedicada à difusão de determinados ditames, modos e padrões em nome da reprodução de uma configuração social; de outro, a demanda de cada um dos indivíduos por preencher suas próprias lacunas com mais saber - não quaisquer saberes, mas aqueles socialmente legitimados como verdadeiros.

Ao sujeito, nessa perspectiva, é mais uma vez atribuída uma posição receptora e passiva nos jogos operados entre poder e verdade. Isso porque, em sua acepção psicanalítica mais geral, a noção de desejo é correspondente a uma falta fundante e constitutiva do próprio sujeito, sendo portanto insolúvel. E é justamente tal impossibilidade de solução do desejo que acabaria por lhe atribuir caráter essencialmente humano e perpétuo. Daí o desejo de 
saber e o desejo de ensinar como causas supostamente inerentes à inflação dos dispositivos pedagógicos.

Nas palavras de Beillerot (1985, p. 142), “o desejo de saber, como todo e qualquer desejo, está condenado a enganar-se no seu objeto, a ignorá-lo e, logo, a perdê-lo. Esta dinâmica encontra-se na base de todas as formações possíveis: o desejo actualizado em necessidade e busca que não poderão ser satisfeitos". Estendendo seu raciocínio às últimas consequências, talvez fôssemos levados a concluir que o próprio movimento de pedagogização social é intrínseco ao caminhar da sociedade, uma vez que seria consequência natural e inevitável de uma correlação essencial: se somos seres perpetuamente desejantes, e se o saber é um dos objetos do desejo, logo tal expansão pedagogizante seria da ordem do inexorável. Uma condição mais que propícia, afinal, a qualquer ensejo de dominação.

Mas é outro o cenário que podemos traçar se à noção psicanalítica de desejo opusermos uma definição diversa, mais afeita à vontade nietzschiana. Em vez de uma falta transcendental lá onde o desejo é causado, veríamos uma força imanente lá onde a vontade se efetua. Isso porque, nessa perspectiva, não é possível "atingir ou conceber um desejo fora de um agenciamento determinado, num plano que não existe previamente, mas que deve ele próprio ser construído" (DELEUZE; PARNET, 2004, p. 113). Assim, em vez de um desejo subordinável aos imperativos de uma luta de forças - ou de classes, no caso da óptica adotada por Beillerot (1985) -, arrisquemo-nos a pensá-lo como protagonista e motor mesmo das lutas de que ele participa.

É essa a via perseguida por Viviane Castro Camozzato e Marisa Vorraber Costa (2013) no diagnóstico que oferecem a respeito de um quadro cuja fisionomia é bastante análoga àquela esmiuçada pelo autor francês. A conjuntura educacional contemporânea aparece assim sintetizada pelas duas pesquisadoras:

Do enfoque ensino-aprendizagem, marcadamente concentrado no interior de espaços escolares, observa-se um crescente deslocamento para análises e debates que sinalizam o quanto as aprendizagens ocorrem em diversificados espaços e artefatos que circundam, transcendem e também atravessam a escola. (CAMOZZATO; COSTA, 2013, p. 22)

A uma leitura atenta não deveria escapar, desde já, uma distinção crucial entre tal formulação e aquela ofertada por Beillerot (1985): trata-se agora não apenas de um fenômeno factual a ser compreendido, interpretado e nomeado pelo saber pedagógico, mas do reconhecimento de uma produção por parte do próprio discurso pedagógico. Ou seja, se 
há alguma inflação pedagógica a ser constatada, ela estaria também no movimento que busca oferecer chaves interpretativas à pedagogização que supõe analisar.

Com efeito, Camozzato e Costa (2013) referem-se à expansão de uma vontade de pedagogia, observada principalmente em três âmbitos: na busca por uma cientifização da pedagogia e no consequente estabelecimento de alianças com outros domínios mais amplos de saber; na flexibilidade com que a pedagogia se ajusta a novos espaços e tempos; em sua incidência ao longo da vida das pessoas. Considerada em uma acepção histórica e, portanto, mutável, a pedagogia é por elas entendida como "marca da contínua vontade de investir e atuar sobre todos os aspectos e âmbitos da vida dos sujeitos contemporâneos - o que faz de cada um de nós um agente de incessante transformação e atuação com os saberes" (CAMOZZATO; COSTA, 2013, p. 23).

No limite, se quiséssemos sobrepor essas duas diferentes análises, seríamos então forçados a admitir que o desejo de saber referido por Beillerot (1985) é ao menos coincidente com uma vontade de pedagogia que lhe é contemporânea. Tais desejo e vontade seriam, assim, ambos protagonistas, ambos agentes ativos nas tramas de seu tempo.

Em tempo, um recuo terminológico. Neologismo conceitual ainda não dicionarizado, o termo Pädagogisierung (pedagogização) foi cunhado pelo sociólogo alemão Janpeter Kob, no final da década de 1950, para referir o processo de modernização social a partir de uma perspectiva educacional (DEPAEPE et al., 2008), inserindo-se no rol de expressões com a finalidade de designar processos em curso que caracterizariam o advento da sociedade moderna - à moda de industrialização, burocratização, urbanização e secularização, todos estes presentes no léxico oficial.

Teria sido apenas na década de 1980, entretanto, que o vocábulo adquiriria legitimidade no meio acadêmico germânico e passaria a contar com termos correspondentes em outras línguas. Para além do idioma alemão, a literatura de língua inglesa foi das que mais demonstrou absorção à noção aí em causa, traduzindo-a ora por educationalization, ora por pedagogization. É esta última a forma hoje mais recorrente também no contexto brasileiro, mas, de modo geral, os dois termos convivem em sinonímia (SMEYERS; DEPAEPE, 2008).

À parte as particularidades de cada análise que dela faz uso, pedagogização tende a ser "uma palavra guarda-chuva para indicar a constante expansão e a dimensão aumentada da ação educacional durante os séculos XIX e, particularmente, XX” (DEPAEPE et al., 
2008, p. 14, tradução nossa). Tratar-se-ia, a princípio, de um conceito meramente descritivo e dotado de alguma neutralidade, mas que com o tempo foi assumindo contornos mais afeitos a uma conotação negativa. Isso porque, na direção oposta de projetos pedagógicos declaradamente aspirantes a promover autonomia, liberdade e emancipação, as consequências de tal expansão passaram a ser avaliadas como aumento de tutela, de dependência, de padronização. Na compreensão de Marc Depaepe et al. (2008, p. 16, tradução nossa):

Em vez de adaptar a sociedade às pessoas, o processo de pedagogização (que constitui a resposta lógica à globalização e à modernização) leva a uma adaptação das pessoas à sociedade neoconservadora. O resultado é, portanto, a domesticação do pensamento, e não a emancipação. A pedagogização [...] é a arte de tornar as pessoas mais "estúpidas" via aprendizagem.

Como aí se vê, estaríamos diante de uma ironia de percurso: se a educação deveria nos tornar sujeitos emancipados, sua ampliação desmedida pelo tecido social teria acabado por nos domesticar. Emancipação versus domesticação, portanto: uma oposição semelhante àquela delineada por Beillerot (1985).

$\mathrm{Na}$ tentativa de compreender de que modo tais processos teriam se materializado, alguns autores os têm vinculado à tendência crescente de tomar os fatos do mundo e da vida cotidiana como problemas a serem resolvidos, tarefa cuja responsabilidade seria então depositada no âmbito educacional, e também por ele reivindicada. É o que poderíamos entender no bojo de uma aprendizagem baseada em problemas (FENDLER, 2008) - ou de uma aprendizagem problematizadora, como diria Paulo Freire.

Vale mencionar que a aprendizagem baseada em problemas (do inglês problembased learning) é uma metodologia pedagógica de ensino-aprendizagem que foi formulada por John Dewey e sistematizada por seu discípulo William Kilpatrick sob a forma de um método de projetos. Lynn Fendler (2008, p. 56, tradução nossa) argumenta que tal metodologia "ilustra o modo particular como a educacionalização atua na pesquisa e na educação escolar atualmente": esquadrinha-se o mundo em termos de problemas e busca-se uma estratégia útil que ofereça condições de resolvê-los. 
Thomas Popkewitz (2008) adota ideia semelhante em sua análise de uma pedagogização ${ }^{12}$ em torno da família e da criança no século XXI. Para ele, o "projeto da criança e da família é o de tornarem-se aprendizes ao longo da vida, indivíduos que vivem de modo flexível por meio da resolução contínua de problemas e da inovação, e cujas ações são legitimadas como direitos "naturais" (POPKEWITZ, 2008, p. 181, tradução e grifos nossos). Intimamente relacionadas, nessa perspectiva, estariam a ascensão de uma visão problematizadora do mundo e a responsabilização crescente em torno de determinada forma de aprendizagem.

São os autores belgas Maarten Simons e Jan Masschelein (2008), no entanto, que parecem desdobrar tal hipótese de forma ainda mais incisiva, mesmo que não a referenciem explicitamente. Em um de seus escritos sobre o assunto, partem eles da consideração de que a centralidade da aprendizagem seria a especificidade a engendrar novos contornos ao estatuto educacional na contemporaneidade. Lançando mão da terminologia foucaultiana, Simons e Masschelein (2008) referem-se à configuração atual da aprendizagem como uma experiência singular, cuja emergência teria se dado em um contexto histórico específico, sobretudo a partir de seu descolamento em relação ao campo do ensino propriamente dito.

Tal emergência, segundo eles, consumaria um percurso de quatro movimentos concernentes à racionalização de problemas de ordens variadas como problemas de aprendizagem, em primeira instância: a capitalização da aprendizagem, no contexto da indústria do conhecimento; por extensão, a compreensão cada vez mais arraigada da empregabilidade como resultado de aprendizagem; a ascensão da defesa de uma educação permanente (ou ao longo da vida); os investimentos na aprendizagem como objeto de autogestão e de autoconhecimento.

Daí a proposição, por eles apresentada, de um novo eixo analítico como crivo de investigação do contemporâneo: o dispositivo de aprendizagem. ${ }^{13}$

Com esse conceito, não nos referimos a um dispositivo criado, implementado ou imposto pelo Estado a fim de organizar a aprendizagem. [...] O que vemos, portanto, não é a 'estatização' ou a dominação da sociedade e do potencial de aprendizagem dos cidadãos pelo Estado, mas uma espécie de 'governamentalização do Estado' em nome da aprendizagem. (SIMONS; MASSCHELEIN, 2008, p. 199, tradução nossa)

\footnotetext{
${ }^{12} \mathrm{O}$ autor utiliza o termo inglês pedagogicalization, mas sua acepção é análoga à expressão mais corrente pedagogization. Por isso, optou-se por assim traduzi-lo.

${ }^{13}$ Learning apparatus, no original.
} 
A governamentalização aí referida seria consoante, portanto, à transformação de desafios políticos em problemas de aprendizagem e à forja de um dispositivo guindado a fonte de soluções para problemas de toda ordem. De certo modo, o que se observa é a transposição para um âmbito fundamentalmente individual - já que alvo de autoconhecimento e de autogestão - de problemas imediatamente políticos e sociais, processo este agora mediado por uma tecnologia de aprendizagem desviada do contexto escolar e de seu pareamento com o ensino.

Se voltarmos às asserções de Beillerot (1985) acerca da existência de um desejo fundamental no cerne do processo de pedagogização, a análise de Simons e Masschelein (2008) oferece-nos um contraponto bastante útil. Isso porque, conforme argumentam os autores belgas, o aparato de aprendizagem requerer uma prontidão voluntária ao aprender, mas que nada tem a ver com um desejo essencial. “Ao contrário, tal 'desejo' é ao mesmo tempo parte desse dispositivo e sua estratégia" (SIMONS; MASSCHELEIN, 2008, p. 199). Ou seja, se há desejo, ele não antecede o dispositivo, mas é seu sucedâneo.

Nessa mesma direção, Stephen Ball [2013] argumenta que a centralização de responsabilidades sociais no plano individual, além de ensejar um estado de aprendizagem perene, modula configurações subjetivas a esse favor. Embasado em documentos referentes à noção de aprendizagem ao longo da vida no contexto europeu, o autor afirma que "o que está sendo construído é uma nova ontologia de aprendizagem e de política e uma 'tecnologia de si' muito elaborada, por meio das quais conformamos nossos corpos e subjetividades de acordo com as necessidades de aprendizagem" [BALL, 2013, p. 145]. Mais uma vez, recusase qualquer articulação entre a disposição a aprender e uma inclinação inerente ao sujeito.

Carlos Ernesto Noguera-Ramírez (2011) também faz coro ao ponto de vista de Simons e Masschelein (2008), ao demarcar a aprendizagem de nossos dias como um problema diretamente afeito à racionalidade governamental. Para ele, “aprender a aprender é a divisa do governamento contemporâneo. Estamos sendo compelidos a nos comportar como aprendizes permanentes, que moram em sociedades de aprendizagem ou cidades educativas" (NOGUERA-RAMÍREZ, 2011, p. 230).

Prossigamos, um pouco mais, no raciocínio em torno do que seria um posicionamento perante o mundo baseado em problemas. Com relação ao contexto social brasileiro, Kamila Lockmann (2016, p. 59) ecoa o que tais autores vêm examinando no 
Hemisfério Norte e afirma reconhecer, também aqui, "uma obsessão contemporânea pela educação". Ao discorrer sobre tal hipótese, ela aponta uma série de questões sociais ("da ordem da saúde, da produtividade, do emprego, do uso de drogas, da gravidez na adolescência") que estariam hoje convertidas em "problemas a serem gerenciados pela educação" (p. 59).

A partir de um levantamento feito em documentos oficiais (como discursos presidenciais e planos de políticas públicas), Lockmann (2016) evidencia, ainda, o modo como a quantificação estatística corrobora tal centralização de soluções no âmbito educacional, ao estabelecer vínculos diretos entre números relativos aos referidos problemas sociais e dados referentes, por exemplo, ao nível de escolarização de grupos populacionais. Como resultado, o que se vê é a produção de um irredutível laço de causa-efeito, de modo que outros vetores também responsabilizáveis pelas variadas mazelas públicas acabam por sair de cena, deixando todo o protagonismo a cargo das práticas educacionais.

Uma aprendizagem baseada em problemas (FENDLER, 2008); uma resolução contínua de problemas (POPKEWITZ, 2008); a transformação de desafios políticos em problemas de aprendizagem (SIMONS; MASSCHELEIN, 2008); a conversão de questões sociais em problemas gerenciados pela educação (LOCKMANN, 2016); a tendência para encarar as questões sociais como problemas que são passíveis de soluções pedagógicas (ROTHES, 2009): algo a respeito do que se passa com certo conjunto de problemas parece ser a tônica comum entre tais autores debruçados sobre o fenômeno da pedagogização/educacionalização. Eis um ponto de inflexão discursiva que interessa esmiuçar. Tanto mais quanto o que se pretende é manter-se nas veredas de uma história das problematizações.

A premissa foucaultiana de que haveria um campo possível do visível, do dizível, do pensável a cada época leva-nos a interrogar a respeito das condições de possibilidade para que algo tenha emergido no horizonte do pensamento, no domínio da ação e da conduta. Trata-se, para já dizer de modo sintético, de uma relação não da ordem da causalidade, mas das respostas que se ofereceram a problemas que até então não haviam sido formulados - e que, portanto, não se apresentavam como problemas. Escreveu Foucault (2014, p. 226):

Várias respostas podem ser dadas para um mesmo conjunto de dificuldades. $\mathrm{Na}$ maior parte do tempo, diversas respostas são efetivamente propostas. Ora, o que é preciso compreender é aquilo que as torna simultaneamente possíveis; é o ponto no qual se origina sua simultaneidade; é o solo que 
pode nutrir umas e outras, em sua diversidade e, talvez, a despeito de suas contradições.

Tal seria a tarefa, enfim, de uma história das problematizações - ou de uma história do pensamento, para variar os termos: "um movimento de análise crítica pelo qual se procura ver como puderam ser construídas as diferentes soluções para um problema; mas também como essas diferentes soluções decorrem de uma forma específica de problematização" (FOUCAULT, 2014, p. 227).

Em busca de rastrear as problematizações formuladas para que se tivesse acirrado um lastro educacionalizante na contemporaneidade - este considerado no estatuto de resposta possível, mas não inevitável, como já deve estar evidente -, eis que se encontra um repertório analítico já traçado a ofertar diagnósticos em que sobram constatações a respeito de uma maneira determinada de problematizar o mundo.

Talvez aí não haja mais que uma coincidência trivial entre os referenciais teóricos que sustentam aquelas análises e os que orientam este trabalho. Certamente haverá. Mas, para além de um modo similar de conduzir as indagações, talvez seja possível arriscar que há algo mais, evidenciado sobretudo nas respectivas asserções de Fendler (2008) e Popkewitz (2008): ambos são explícitos quando se referem a uma forma específica, e recente, de se relacionar com o mundo, tomando-o sempre como motivo à busca por soluções.

Ora, compreender a história como um torvelinho sucessivo de problematizações implica conceber um princípio geral de possibilidades de pensamento, de discurso, de conduta, de relações consigo próprio e com as verdades de um tempo. Não significa, entretanto, supor que haveria um modo específico de se relacionar com os acontecimentos que nos atravessam. Se há, será também ele alvo de historicização. De um lado, falamos em uma problematização a ser arquitetada pelo próprio exercício analítico; de outro, falamos em uma problematização aderida às condutas de um tempo.

Tentemos, então, dispor de forma mais direta essa sobreposição confusa entre problematizações de ordens distintas: se é correto presumir que nosso atual endereçamento às questões com que nos defrontamos tem a forma de uma permanente problematização em busca de soluções - redundando em uma aprendizagem baseada em problemas, por exemplo -, haveria aí uma circunstância fortuita, em relação à qual seria preciso interrogar quais teriam sido os problemas que a engendraram como resposta possível. Como, afinal, teríamos 
nos tornado sujeitos que ativamente problematizam o mundo? Por extensão, como teríamos encontrado na educação as respostas predominantes a tais problemas?

Se já são duas as linhas que compõem nosso entrelaçamento das problematizações, eis a deixa para uma terceira: a pedadogia problematizadora proposta por Paulo Freire como sinônima da pedagogia libertadora com a qual ele se consagrou. Para o autor, uma das chaves da liberdade a ser perseguida na resistência a uma educação bancária residiria, fundamentalmente, em uma atitude problematizadora perante o mundo.

\begin{abstract}
A educação que se impõe aos que verdadeiramente se comprometem com a libertação não pode fundar-se numa compreensão dos homens como seres 'vazios' a quem o mundo 'encha' de conteúdos; não pode basear-se numa consciência especializada, mecanicistamente compartimentada, mas nos homens como 'corpos conscientes' e na consciência como consciência intencionada ao mundo. Não pode ser a do depósito de conteúdos, mas a da problematização dos homens em suas relações com o mundo. (FREIRE, 1987, p. 67)
\end{abstract}

A reboque de uma tal defesa, como se vê, mais uma vez a intencionalidade é convocada a assumir posto, agora notadamente em nome de uma função desalienadora. Por meio da problematização, os educandos vislumbrados por Freire deveriam tornar-se cada vez mais criticamente conscientes a partir dos desafios abertos via a formulação de problemas. "Quanto mais se problematizam os educandos, como seres no mundo e com o mundo, tanto mais se sentirão desafiados. Tão mais desafiados, quanto mais obrigados a responder ao desafio" (FREIRE, 1987, p. 70). Tratar-se-ia, afinal, de uma prescrição: pôr-se sempre à caça de respostas - "não só no nível intelectual, mas no nível da ação" (p. 86) -, a serem encontradas via mediação educacional.

É patente que a teorização freireana não pode ser responsabilizada por incutir na sociedade um endereçamento ao mundo via respostas educacionais, fundado na formulação de problemas e na busca por solucionar os desafios assim traçados. Tal associação seria leviana e infundada. Embora uma parte considerável do discurso educacional seja bastante permeável às asserções do autor pernambucano, supor uma aplicação direta e de alcance internacional a partir do que foi por ele sugerido resultaria em grave insensatez.

Mas não deixa de ser sugestivo o paralelismo entre suas proposições e os fenômenos que vêm sendo identificados pelos autores aqui referidos. Em última instância, ao nutrir suas asserções de um intento ininterruptamente formulador de problemas e soluções educacionais 
a partir da realidade social, Freire demonstrava estar em íntima consonância com os imperativos discursivos de seu tempo. Em vez de apresentar resistência aos modos de aprendizagem em curso, ele talvez estivesse paradoxalmente a exacerbá-los.

Escolarização, pedagogização e educacionalização são substantivos formados pelas mesmas regras que dão origem a termos como modernização, industrialização, burocratização, medicalização e racionalização, entre diversos outros. Em comum, partem de verbos que denotam o movimento de tornar(-se) algo: modernizar(-se) é tornar(-se) moderno, na mesma medida em que burocratizar(-se) é tornar(-se) burocrático. Quando convertemos tais ações em substantivos, designamos um movimento linear e ascendente de um ponto a outro em determinada escala. Assim, a modernização de uma sociedade refere-se ao processo contínuo e crescente por meio do qual essa sociedade moderniza-se progressivamente. Talvez haja aí uma teleologia da qual seria desejável escapar, mas que por vezes resulta inevitável diante do esforço analítico de compreensão de determinados fenômenos.

Em certo sentido, quando se fala em escolarização, pedagogização e educacionalização, presumem-se movimentos que qualificam práticas educativas preexistentes, latentes no interior das relações sociais. A depender da época analisada e da abordagem investigativa, tais práticas tornar-se-iam, respectivamente, mais escolares, mais pedagógicas, mais educacionais.

E se supusermos, no entanto, que não há uma educabilidade intrínseca, que ela é efeito produtivo e não capacidade essencialmente humana ou atributo inerente a determinadas ações e contextos? Daí, talvez, será plausível arriscar o acréscimo de mais um termo àquela lista de substantivos denotando processos afluentes: educabilização.

Dito de outro modo, a partir da proposição desse novo neologismo, trata-se de convocar atenção para o processo de atribuição de um potencial educativo a sujeitos, práticas e espaços. Trata-se, ainda, de supor que nada é educativo a priori, mas que há, em tais movimentos ora investigados, a produção de uma educabilidade praticamente irreversível, porque exitosamente tornada familiar, universal, essencial. 
A todos parece ser evidente que a escola não existiu desde sempre e que poderá não existir em um futuro próximo. No entanto, não se formula com a mesma clareza que a própria educabilidade também tem sua história. Da crítica relativa ao estatuto escolarizado da sociedade moderna às várias constatações de crise a esse respeito, nenhuma menção a uma possível deseducabilização dos aparatos sociais. Pelo contrário, parece sempre necessário expandir a alçada educativa, investindo-a de uma alegada intencionalidade.

No bojo desse processo, em sua configuração recente, abre-se espaço para que âmbitos diversos da vida cotidiana constituam terreno fértil ao elenco de problemas cuja solução residiria na aprendizagem como contrapartida fundamental. É porque virtualmente tudo se torna dotado de educabilidade que é possível aprender a todo instante ao longo da vida; que é possível, enfim, escolarizar, pedagogizar, educacionalizar. E assim nos tornamos cidadãos aprendizes, antes de mais nada, já que protagonistas de um mundo educabilizado. Nesse sentido, a educabilidade e a aprendizagem formam um par inconteste, em contraposição à consagrada dupla ensino-aprendizagem. A educação pode, enfim, descolarse do ensino e centrar-se na aprendizagem permanente quando tudo se dá em um mundo plenamente educabilizável.

Illich e Freire, uma vez mais, são figuras paradigmáticas de como as utopias possíveis em um tempo ressoam o que então há de mais entranhado em seu tecido veridictivo. Daí que seus projetos podem não ser institucionalizados, escolarizados, formalizados, mas são intensamente educabilizados.

Para manter a alegoria aludida no início deste capítulo, tais cenários jamais seriam habitados ou visitados por dragões, esses seres fantásticos que se recusam a ocupar paraísos forjados por nós próprios, pessoas banais, crias legítimas de nosso tempo. Paraísos que, aliás, já habitamos enquanto acreditamos arquitetá-los para um futuro porvir. 


\section{ENTRE GESTOS E FONTES DE PESQUISA}

É tempo de nos demorarmos um pouco mais em algumas perguntas: afinal, como é possível perscrutar uma experiência que é a nossa própria, no instante mesmo em que a vivemos? Como esgarçar nexos que nos são demasiado onipresentes e, ao mesmo tempo, tão imponderáveis? Onipresentes porque imponderáveis, talvez; imponderáveis porque onipresentes, decerto. Ainda, de que modo é possível reconhecermo-nos bastiões daquilo que está cosido no próprio tecido que nos entranha? Eis alguns embaraços desse exercício de se tomar o próprio presente como matéria ao pensamento.

Mas todo presente tem uma história, ou melhor, várias delas: das que se dissiparam no correr do tempo àquelas que sustentam sua suposta inevitabilidade. E é definitivamente longe dessa última suposição que este trabalho se pretendeu efetuar. Ao contrário, a tarefa de historicizar o presente, conforme aqui reputada, é, antes, o esforço de forjar alguma distância entre nós e nós mesmos. Afinal, como é sempre bom lembrar, "o que é poderia ser diferente; os fatos humanos são arbitrários, [...] não são óbvios, no entanto parecem tão evidentes aos olhos dos contemporâneos e mesmo de seus historiadores que nem uns nem outros sequer os percebem" (VEYNE, 1982, p. 151).

Entre as evidências de nosso tempo, suponhamos que a educação, em suas variadas formas, conste da lista de prerrogativas inquestionáveis. Em geral, de sua defesa à sua oferta, passando pela demanda que lhe é endereçada e que lhe atribui condição de direito inalienável, a tarefa educativo-formativa apenas parece ser alvo de discórdia quanto aos princípios de sua efetivação, mas nunca quanto a alguma imprescindibilidade. Ela perfaz, assim, um horizonte de estatuto universal, cujo traçado histórico - quando não se supõe uma existência desde sempre dada - costuma ser composto por uma linha progressiva, crescente. Das duas, uma: ou a educação consistiria em uma dimensão intrínseca à experiência humana, ou a estatura por ela atingida (ou almejada) seria sinal de êxito comparativamente a contextos anteriores, de modo que é preciso dela nunca abdicar, mas sempre expandi-la - seja por meio da escola, seja pelo seu avesso.

Se é plausível supor que o clamor por mais educação configura uma das unanimidades contemporâneas - aí previstas raras divergências -, tratar-se-ia, por extensão, de um dos vetores imediatamente envolvidos nos processos de subjetivação em que nos encontramos enredados. Como se sempre assim houvesse sido, como se fosse óbvio que assim o fosse. Como se aí residisse algo de uma experiência humana, de uma experiência 
essencial. Mas uma "experiência é sempre uma ficção; é algo que se fabrica para si mesmo, que não existe antes e que existirá depois" (FOUCAULT, 2013b, p. 293).

Sigamos, então, a trilha aberta por Foucault (2008b, p. 5) e "suponhamos que os universais não existem". Endereçarmo-nos ao nosso presente, sob essa perspectiva, implica

[...] marcar a singularidade dos acontecimentos, longe de toda finalidade monótona; espreitá-los lá onde menos se os esperava e naquilo que é tido como não possuindo história - os sentimentos, o amor, a consciência, os instintos; apreender seu retorno não para traçar a curva lenta de uma evolução, mas para encontrar as diferentes cenas onde eles desempenharam papéis distintos; e até definir o ponto de sua lacuna, o momento em que eles não aconteceram. (FOUCAULT, 2005, p. 15)

Nisto consiste, pois, o gesto genealógico ora pretendido: na tentativa de fazer despontar as emergências contingentes de um acontecimento discursivo que hoje parece afirmar-se de modo automultiplicador e autolegitimador. Em vez de recorrer à história a fim de decifrar caminhos que inequivocamente teriam desembocado em um desfecho já sabido o próprio presente -, trata-se, justamente pelo inverso, de evidenciar a relação não necessária entre os dois polos; de partir em busca de liames outros e imprevistos com acontecimentos vizinhos, até então apartados do rol de alegadas causalidades. Trata-se, enfim, de recusar toda e qualquer teleologia.

Seguir o filão complexo da proveniência é, ao contrário, manter o que se passou na dispersão que lhe é própria: é demarcar os acidentes, os ínfimos desvios - ou ao contrário as inversões completas - os erros, as falhas na apreciação, os maus cálculos que deram nascimento ao que existe e tem valor para nós; é descobrir que na raiz daquilo que nós conhecemos e daquilo que nós somos - não existem a verdade e o ser, mas a exterioridade do acidente. (FOUCAULT, 2005, p. 21)

Quais acidentes, quais desvios teriam dado lugar ao que hoje somos, pensamos e valoramos, em termos educacionais? Qual será o desenho da dispersão em que nossa experiência - de sujeitos contemporâneos atravessados por um irredutível lastro educativoformativo - constituiu-se? Que emergências e que proveniências se encontram nos vários começos dessa história?

Rastrear possíveis respostas a perguntas tão amplas requer um esforço da ordem da minúcia em busca por problematizações alheias e alhures, ou seja, por aquilo que, a cada inflexão do tempo, apresentou-se como problema aos homens, aos saberes, às várias disciplinas, forjando matrizes veridictivas que então passaram a conduzir o que se sucedeu; 
forjando, ainda, as respostas que hoje não hesitamos em oferecer. Daí porque a genealogia foucaultiana é também uma história das problematizações. Perguntaríamos, então: a que problemas se pretendeu responder para que tal fosse o estatuto educacional de nosso presente?

Ainda, além do gesto genealógico, invoquemos o arqueológico, cujas relações com o primeiro são mais de complementaridade do que de distinção, tal como salienta Paul Veyne (1982, p. 181):

Toda história é arqueológica por natureza e não por escolha: explicar e explicitar a história consiste, primeiramente, em vê-la em seu conjunto, em correlacionar os pretensos objetos naturais às práticas datadas e raras que os objetivizam, e em explicar essas práticas não a partir de uma causa única, mas a partir de todas as práticas vizinhas nas quais se ancoram. Esse método pictórico produz quadros estranhos, onde as relações substituem os objetos.

Perfurar uma massa discursiva requer desvelo constante, tão ardilosa que é sua superfície. A depender do atalho tomado, ela pode se prestar a revelar continuidades, semelhanças, fundamentos, recorrências, linearidades, totalidades; ou, então, raridades, descontinuidades, contingências, extravios. Lançar-se na segunda rota implica estar atento, sobretudo, aos acontecimentos que se desenham no horizonte do arquivo, estes entendidos como ocasiões contíguas às problematizações que se ofertaram em matéria ao pensamento. Contingências a serem acontecimentalizadas, (FOUCAULT, 2006) ou seja, vislumbradas em sua raridade lá onde tenderíamos a ver constantes históricas: eis a singularidade dos acontecimentos discursivos.

Trata-se, enfim, de estabelecer relações de vizinhança entre um acontecimento e outro, sempre no encalço de emergências e proveniências. Tais relações,

[...] entretanto, não constituiriam, de maneira alguma, uma espécie de discurso secreto, animando, do interior, os discursos manifestos; não é, pois, uma interpretação dos fatos enunciativos que poderia trazê-los à luz, mas a análise de sua coexistência, de sua sucessão, de seu funcionamento mútuo, de sua determinação recíproca, de sua transformação independente ou correlativa. (FOUCAULT, 2013a, p. 36)

O intento é em tudo distinto da busca por identidade. Uma vez mais, o que se quer é distância, é deslocamento. Se bem-sucedido for o gesto que aí se esboça, ele não nos deve levar a desvendar traços de uma similitude pareada a si mesma. Em vez disso, o trabalho do pensamento "dissipa essa identidade temporal em que gostamos de nos olhar para conjurar as 
rupturas da história [...]. Ele estabelece que somos diferença. [...] Que a diferença, longe de ser origem esquecida e recoberta, é a dispersão que somos e que fazemos" (FOUCAULT, 2013a, p. 160).

São esses os rumos que vêm sendo perseguidos desde a primeira página deste trabalho. Também desde lá se dispõe o que se poderia considerar um campo expandido das fontes postas em jogo. Se é oportuno estabelecer esta paragem para tratar de procedimentos, não é porque aqui se começa um suposto núcleo duro do trabalho. Mas apenas porque dela não se pôde prescindir, já que a tessitura de um arquivo, longe de instantânea, foi arquitetada em seus pormenores, talhada por escolhas que se faz necessário apresentar.

\subsection{O arquivo, uma turba de acontecimentos}

A fim de pôr em movimento as várias indagações já anunciadas, a produção acadêmico-científica nacional foi tomada como locus analítico, entendida como um nicho discursivo suficientemente sólido e abrangente para evidenciar aquilo que vem se operando no campo educacional em tempos recentes. Tal fonte, por um lado, pode ser pensada como um dos suportes concretos de reconhecimento e validação do estatuto pedagógico das relações educativas internas e externas à instituição escolar; por outro, trata-se de uma significativa superfície de reverberação daquilo que se passa no campo das práticas concretas, uma vez que permite circular apropriações de ensejo teorizante dessas mesmas práticas. Essas duas características são indissociáveis e, juntas, denotam o caráter performativo do material em análise, que ademais ofereceu a possibilidade de se aceder a um conjunto massivo e regular de textos redigidos ao longo de determinado período.

Inicialmente, foram selecionados dez periódicos da área educacional. À medida que a análise do arquivo avançou, porém, a expansão das fontes utilizadas foi se tornando uma medida necessária. Isso porque, a fim de oferecer lastro empírico ao trabalho, tal extensão tornou-se requisito fundamental ao efeito analítico que se pretendia. Afinal, na tentativa de cartografar um universo discursivo contemporâneo, inventariando os caminhos que nele foi tomando cada linhagem das temáticas encontradas, a dispersão almejada requeria o acesso mais extenso possível ao campo empírico.

O corpus analítico foi, então, consideravelmente incrementado, passando a incluir um total de 34 publicações. O crivo para a seleção de tais publicações fundamentou-se na 
avaliação estabelecida pela plataforma Qualis CAPES: dos periódicos incluídos nas classificações A1, A2 e B1, foram escolhidos aqueles dedicados a discussões gerais do campo educacional (excluindo-se, por exemplo, publicações devotadas a áreas específicas, como educação matemática, ensino de história, educação inclusiva etc.). Com esse incremento, a pesquisa passou a dispor, supõe-se, de um quadro bastante fidedigno da produção educacional que circulou pelos meios acadêmicos ao longo das últimas décadas.

Em sua configuração final, foi este o conjunto de periódicos abarcados: Acta Scientiarum. Education; Cadernos CEDES; Cadernos de Educação; Cadernos de Pesquisa; Contrapontos; Currículo sem Fronteiras; E-curriculum; Educação (PUCRS); Educação (UFSM); Educação \& Realidade; Educação \& Sociedade; Educação e Cultura Contemporânea; Educação e Pesquisa; Educação em Foco (UEMG); Educação em Foco (UFJF); Educação em Questão; Educação em Revista; Educação Temática Digital; Educação Unisinos; Educar em Revista; Em Aberto; Inter-Ação; Linhas Críticas; Perspectiva; Práxis Educativa; Pro-Posições; Revista Brasileira de Educação; Revista Brasileira de Estudos Pedagógicos; Revista da FAEEBA; Revista de Educação Pública; Revista de Educação PUC-Campinas; Revista Diálogo Educacional; Revista IberoAmericana de Estudos em Educação; Teias.

Das 34 publicações, uma específica estava, desde o início, destinada a receber um tratamento distinto do restante do material - a saber, a Revista Brasileira de Estudos Pedagógicos $(R B E P)$. Por motivos que serão pormenorizados adiante, sobre a RBEP incidiu uma investida analítica mais extensa quanto ao recorte temporal, na intenção de aí criar um recuo - ainda que tímido - e proporcionar uma distância maior em relação ao que nos é hoje familiar. Assim, ela foi examinada na totalidade de suas publicações, desde o ano de sua criação, em 1944, até o final de 2015, sendo este o limite temporal que nos foi possível alcançar.

No conjunto de suas edições até o ano de 1995, a RBEP compõe, sozinha, a primeira porção das fontes. No intervalo entre $1996^{14}$ e 2015 , porém, ela se soma às demais 33 revistas, cujos fascículos considerados dispõem-se ao longo dessas últimas duas décadas. Eis, afinal, o quadro de fontes sobre o qual esta pesquisa se debruçou: de um lado, um único

\footnotetext{
${ }^{14}$ Além de permitir a abrangência exata de duas décadas inteiras, o limite temporal inicial foi fixado em 1996 por ser este o ano de promulgação da última Lei de Diretrizes e Bases da Educação Brasileira (Lei no 9.394), que estabelece a "valorização da experiência extra-escolar" como um dos princípios que devem reger o ensino (BRASIL, 1996). A versão antecedente do documento (Lei $n^{\circ}$ 5.692), datada de 1971, não fazia qualquer menção ao tema (BRASIL, 1971).
} 
feixe, verticalizado, concentrado em um periódico e com uma distribuição cronológica mais alongada; de outro, a dispersão de um leque, horizontalizado, mas com uma distribuição cronológica mais condensada.

A diferença de abordagem entre essas duas porções do material derivou de uma bifurcação metodológica apenas formal, a título de operacionalizar os dois gestos já mencionados. No primeiro caso, a intenção consistiu em flagrar determinados momentos em que as problemáticas identificadas no discurso recente irrompiam no bojo de discussões para as quais elas ainda não eram resposta predominante, embora ali estivessem em germe. $\mathrm{O}$ intento era buscar sua emergência em uma discursividade dispersa, na qual, decerto, conviviam outras possibilidades enunciativas. No segundo caso, tratava-se de cartografar tal material de modo a compor um inventário dos saberes, das práticas e dos modos de intervenção que têm sido direcionados à experiência educativa não escolar.

A esta altura, faz-se válida uma digressão a respeito da lida com o material, essa “população de acontecimentos no espaço do discurso em geral” (FOUCAULT, 2013a, p. 32). Não sendo neutra ou estritamente objetiva, uma vez que não determinada a partir de critérios previamente fixados, a construção do arquivo desta pesquisa foi, ela própria, uma empreitada analítica. Era preciso ir às fontes, espreitá-las em sua extensão e na intimidade de sua trama, para apenas então orçar os contornos das interrogações que a elas se poderia endereçar. Isso não significa, claro está, que o manuseio primeiro do material prescindisse de um eixo investigativo preciso que o atravessasse. Mas é no encontro entre as conjecturas iniciais e o que se supôs matéria de análise que aquelas deixam de ser incipientes e adquirem espessura empírica. Há um ajuste a ser feito entre um âmbito e outro para que surja um arquivo, tal como o concebemos, e para que o problema da pesquisa se apresente de forma mais definitiva.

Ora, fontes bibliográficas podem ser tratadas de formas as mais diversas. As premissas de que se parte ao elegê-las compõem boa parte da especificidade de cada tipo de análise, mas há que se considerar o método utilizado para interrogá-las, os propósitos que se têm em vista e também outras concepções mobilizadas nos alicerces do trabalho. Recorramos a um exemplo interno: da primeira à última de suas páginas, a armação deste trabalho deriva fundamentalmente de recursos de cunho bibliográfico, sem, no entanto, dispensar a todos eles um mesmo tipo de trato. Ao menos, foi essa sua ambição. 
Enquanto determinados conjuntos textuais são mais úteis para desenhar o universo temático sobre o qual se pretende incidir, outros o são na arquitetura da estratégia de incisão; alguns, por sua vez, prestam-se a ser matéria-prima, em estado bruto, para o pensamento que se está a forjar. A esse último bloco pertence o que aqui se entende por arquivo. No esforço de defini-lo conforme as denominações correntes no jargão acadêmico-científico, empírico lhe seria um atributo apropriado, pois é seu nexo com determinada experiência - na acepção já aqui exposta - que interessa colocar em marcha.

Nexo, vale dizer, que não está pautado pela representatividade, por uma relação todoparte unívoca entre discursos e realidades, de tal modo que aqueles fossem mostra fidedigna destas. É justamente por entendê-lo no interior de uma empiria que ao arquivo conferimos caráter de uma dentre tantas práticas próprias de um tempo, em consonância com o modo como Arlette Farge (2009, p. 35) a ele se reporta: "Talvez o arquivo não diga a verdade, mas ele diz da verdade, tal como o entendia Michel Foucault [...]. O real do arquivo torna-se não apenas vestígio, mas também ordenação de figuras da realidade; e o arquivo sempre mantém infinitas relações com o real". Com isso se quer afirmar que, se não há pretensão de representar algo que corresponderia de forma direta a uma realidade factual, há, entretanto, a tentativa deliberada de tomar um conjunto discursivo específico como ocasião de reflexão e tensionamento do que ele próprio opera em sua condição de prática efetiva.

Entre vestígios, ordenações possíveis e relações infinitas, são várias as camadas combinatórias que aí se sobrepõem. A elas se somam outras inerentes ao próprio procedimento investigativo: sendo o arquivo entendido como resultado de coleta e construção do pesquisador, ele diz de novas realidades a cada vez que se forja, sobretudo quando se busca não a verdade de um passado, mas um diálogo extemporâneo desse mesmo passado com problemas presentes - também estes realçados por meio de uma combinação estratégica de contingências e referenciais teóricos. Assim definida, a lida com as fontes empíricas consiste em um apurado trabalho de manufatura afeita à artesanal: é preciso produzir os instrumentos do manejo e editar o material em estado bruto, para então esculpi-lo, pari passu ao próprio ato da análise. Sua forma final, embora imprevista sob muitos aspectos, não é aleatória, pois depende do encaixe entre as propriedades da ferramenta e as da matéria-prima. 


\subsection{A Revista Brasileira de Estudos Pedagógicos}

Desde os levantamentos iniciais, a RBEP foi peça basilar do plano da pesquisa. As razões para tanto vinculam-se ao contexto de sua fundação, ao amplo espectro temporal de sua existência, bem como aos autores e aos debates que estiveram presentes em suas páginas.

Criada em 1944 pelo Instituto Nacional de Estudos Pedagógicos (Inep), órgão fundado em 1937 e mantido pelo Ministério da Educação - então Ministério da Educação e Saúde -, ela foi das primeiras revistas brasileiras dedicadas a veicular estudos e debates específicos do campo educacional, permanecendo até hoje como uma publicação de grande circulação e relevância na área.

Embora suas raízes e vinculações oficiais com a administração pública configurem recorrente pretexto para que ela seja tomada - ou, em outros casos, rechaçada - como objeto de estudo ou fonte documental, não foi exatamente esse aspecto que a trouxe à frente desta pesquisa; não nesses termos, ao menos. Isso porque não interessava pensar disposições oficiais de governo como mais, ou menos, determinantes ou emblemáticas que outras, e sim como uma das várias forças em jogo. Se não é pelo caráter oficial que a revista adquire vulto, é antes pelas intencionalidades supostas nas circunstâncias de sua formulação. Vale evocar na íntegra a apresentação que a revista trazia em sua contracapa nas primeiras edições:

REVISTA BRASILEIRA DE ESTUDOS PEDAGÓGICOS, órgão dos estudos e pesquisas do Ministério da Educação e Saúde, publica-se sob a responsabilidade do Instituto Nacional de Estudos Pedagógicos, e tem por fim expor e discutir questões gerais da pedagogia e, de modo especial, os problemas da vida educacional brasileira. Para isso aspira a congregar os estudiosos dos fatos educacionais no país, e a refletir o pensamento de seu magistério. REVISTA BRASILEIRA DE ESTUDOS PEDAGÓGICOS publica artigos de colaboração, sempre solicitada; registra, cada mês, resultados de trabalhos realizados pelos diferentes órgãos do Ministério e dos Departamentos Estaduais de Educação; mantém seção bibliográfica, dedicada aos estudos pedagógicos nacionais e estrangeiros. Tanto quanto possa, REVISTA BRASILEIRA DE ESTUDOS PEDAGÓGICOS deseja contribuir para a renovação científica do trabalho educativo e para a formação de uma esclarecida mentalidade pública em matéria de educação. [RBEP, 1944a]

Projetada para ser um baluarte da cena educacional brasileira, como aí se vê, a $R B E P$ lançou-se sob o compromisso não apenas de representar e fazer circular as produções validadas pelo Instituto, mas também de estabelecer paradigmas gerais de ordenação do que se pensava, do que se propunha e do que se fazia em matéria de educação no país. Nesse 
sentido, estava diretamente vinculada a determinadas perspectivas e diretrizes já em curso, o que torna especialmente relevante uma menção às suas ligações com o pensamento escolanovista, cuja emergência no Brasil concentrou-se na década anterior ao aparecimento da revista.

Foi sob a direção de Manoel Bergström Lourenço Filho, então diretor do Inep, que a RBEP esteve em seus primeiros anos (1944-1946); posteriormente, Anísio Teixeira ocupou o posto (1952-1964). Só aí já temos dois nomes diretamente ligados ao movimento da Escola Nova, ambos de presença assídua também entre os colaboradores da revista, para além do exercício em cargos burocráticos. Assim, pode-se dizer que, "nas três primeiras décadas, sob a marcante influência de Lourenço Filho e Anísio Teixeira, a Revista, como órgão oficial do MEC-Inep, assegurou a hegemonia do pensamento renovador" [SAVIANI, 2012, p. 317]. E uma publicação surgida em um cenário que discutia justamente a reformulação da instituição escolar apresenta-se como ainda mais atrativa aos intentos desta investigação.

Com efeito, o editorial da primeira edição da RBEP, em 1944, afirmava estar em curso uma "expansão geral da rede escolar do país", apontando o desenvolvimento de uma "consciência de maior unidade da cultura brasileira a ser difundida e aprofundada pela obra da escola" [RBEP, 1944a, p. 5, grifos nossos]. Assim, ao menos nas expectativas dos idealizadores da revista, a instituição escolar era pauta central do debate que ali seria veiculado.

Já em 1967, a julgar pelo texto de abertura do fascículo de número 108, o contexto havia se transformado, fazendo-se acompanhar de perto por uma transformação também no foco dos responsáveis pelo periódico. Alegando-se diante de uma explosão demográfica, o editorial daquela edição estava convicto de que "não será com a escola tradicional, no seu modêlo típico e caricatural, que se poderá atender às reivindicações da clientela. Êsse tipo de escola já se revelou incapaz de responder às necessidades e imperativos da instrução universal e permanente" [RBEP, 1967c, p. 205].

Passados 70 anos e 236 edições, um artigo publicado no periódico mencionava a “tendência contemporânea de produzir intervenções culturais, ou político-culturais, nas condições de vida dos habitantes das cidades brasileiras", e se atribuía a tarefa de analisar “intervenções educativo-culturais focalizadas na formação cultural dos indivíduos" [SILVA, R., 2013, p. 250]. 
Do primeiro aos outros dois excertos, parece ter havido um deslocamento entre dois modos distintos de endereçamento ao intento educativo: de um lado, a aposta na escola como locus, por excelência, da experiência formativa; de outro, a descentralização daquela mesma instituição em favor de intervenções pulverizadas social, cultural e politicamente. Que tal deslocamento não tenha ocorrido em um processo linear e progressivo é ponto pacífico da presente pesquisa. No entanto, é nas tramas existentes de um extremo ao outro que ela pretendeu embrenhar-se. E, mais uma vez, a revista editada pelo Inep mostrou-se fonte especialmente profícua para esse fim.

Como já dito, a $R B E P$ oferece material compreendido em um largo espectro temporal, o qual foi integralmente considerado na análise. Ao longo de sua história, a revista não manteve um padrão único de publicação, nem em termos de regularidade, nem no que se refere à extensão e ao formato de cada uma de suas edições. Ao contrário, suas alterações durante os anos foram diversas, o que condiz com o caráter de uma publicação diretamente vinculada a um órgão público - e às suas consequentes variações políticas e administrativas , bem como com as transformações ocorridas nos próprios parâmetros editoriais posteriormente adotados pelos periódicos acadêmicos brasileiros.

Segundo alguns autores, os momentos de indefinição da RBEP coincidem com fases tumultuosas do próprio Inep, sobretudo no período em que a revista esteve na posição de porta-voz das políticas e proposições do Instituto [ROTHEN, 2005]. Tal correlação direta, no entanto, acabaria por se diluir com o tempo, devido à "passagem de seu perfil original de órgão oficial do Ministério da Educação (MEC) para a condição de revista organizada segundo o padrão corrente dos periódicos científicos" [SAVIANI, 2012, p. 309].

Ainda no que diz respeito aos conflitos que perpassaram a trajetória tanto da $R B E P$ quanto do Inep, é válido salientar sua passagem pelo final da Segunda Guerra Mundial, o que se fez tema recorrente no conteúdo da revista nas décadas de 1940 e 1950, e pelo regime militar brasileiro (1964-1985), período em que a revista ainda estava diretamente à mercê das transformações ocorridas no Instituto.

Editor da RBEP por um total de 20 anos (1960-1976 e 1984-1986), Jader de Medeiros Britto esteve à frente da revista no início do referido regime e ao longo de sua primeira década. Em entrevista concedida em 2012, ele não relata qualquer alteração substancial na revista decorrente do momento político vivido à época. À parte uma tensão quanto à possível extinção do próprio Inep (o que não chegou a se concretizar), Britto [2012, p. 540] afirma 
que, "com a implantação do regime militar, houve especial preocupação em manter a linha editorial da Rbep". Isso incluiria, segundo ele, a veiculação de textos de autores já frequentes na publicação, como Anísio Teixeira, que, como já referido, esteve na direção do Inep entre 1952 e 1964, exercendo grande influência sobre a linha editorial da revista. Hoje se tem fortes indícios, no entanto, de que Teixeira teve sua morte motivada por intentos do regime militar (JOSÉ, 2014), o que nos leva a pôr em questão a alegada incolumidade da RBEP durante os anos em que os militares estiveram à frente do governo do país. ${ }^{15}$

No que concerne à regularidade da publicação, se nos primeiros anos sua frequência tendia a ser maior (tendo chegado a publicações mensais em 1945, ano com maior quantidade de edições da revista), com o tempo ela se tornou mais espaçada: entre 1951 e 1974 mantevese trimestral, com algumas exceções; entre 1975 e 1983 teve seu período de maior rarefação, inclusive sem nenhum número produzido nos anos de 1975, 1981 e 1982; a partir de 1984 estabeleceu-se em regularidade quadrimestral, tal como permanece até o momento. Ao todo, durante os 72 anos aqui considerados (1944-2015) foram publicados 244 números.

Quanto ao formato, pode-se dizer que a $R B E P$ teve de início um conteúdo substancialmente diferente daquele que apresentou nas últimas décadas. A distribuição de suas seções é boa mostra de tais alterações, e embora os artigos científicos tenham sido constantes em todos os números, a revista já contou com outras categorias textuais que, em determinados períodos, ocuparam mais espaço do que os artigos, propriamente. Entre elas, seções de debate, legislação, acontecimentos educacionais no Brasil e no mundo, resumos de revistas e jornais, resenhas de livros, orientações pedagógicas, bibliografias, documentações e atos oficiais. Também os textos editoriais de caráter introdutório a cada número apresentaram irregularidades, estando ausentes em alguns intervalos temporais. Atualmente, a revista é basicamente composta por seções de artigos e resenhas, o que denota o movimento de academicização e especialização do periódico.

Com o tempo, a RBEP passou a dividir espaço com outras revistas da área. Conforme assinala Dermeval Saviani [2012], é indicativo que ela venha sendo avaliada pelo Qualis

\footnotetext{
${ }^{15}$ Entre outros pesquisadores, José Augusto de Lima Rocha, professor da Universidade Federal da Bahia, dedica-se a apurar as circunstâncias da morte de Anísio Teixeira, que foi tema investigado também pela Comissão Nacional da Verdade. Engenheiro de formação, Rocha utiliza-se de seus conhecimentos em física para analisar laudos e fotos do local em que o corpo do intelectual baiano foi encontrado, contestando a versão oficial para o acidente (a queda no poço de um elevador). Segundo ele, Anísio Teixeira "nunca foi militante partidário, mas sua atuação de educador, desde 1924, certamente não era da simpatia dos setores conservadores, por certo interessados na manutenção do estado de ignorância que, para eles, favoreceria manterem-se eternamente no poder" (ROCHA, 2016).
} 
CAPES na classificação $\mathrm{B} 1,{ }^{16}$ afinal, como se trata de um ranking comparativo, tal resultado demonstraria que muitos outros periódicos hoje disputam lugar na liderança das publicações educacionais no país.

É possível que essas considerações justifiquem o fato de que o conjunto massivo de artigos que se mostraram de interesse na composição do arquivo concentram-se nas primeiras décadas de circulação da $R B E P$, quando ela se prestava a suporte dos intentos reformistas nutridos pelos intelectuais de destaque no cenário político da época. No entanto, as próprias variações apresentadas ao longo de sua história foram de grande valia para o estudo, uma vez que possibilitaram acesso a escritos de origens e condições mais dispersas e menos formatadas, o que permitiu compor um universo mais amplo para a análise.

O gráfico a seguir apresenta a distribuição cronológica dos textos que foram selecionados a partir dos interesses temáticos da presente pesquisa.

Gráfico 1: Distribuição dos artigos selecionados por ano (1944-1995)

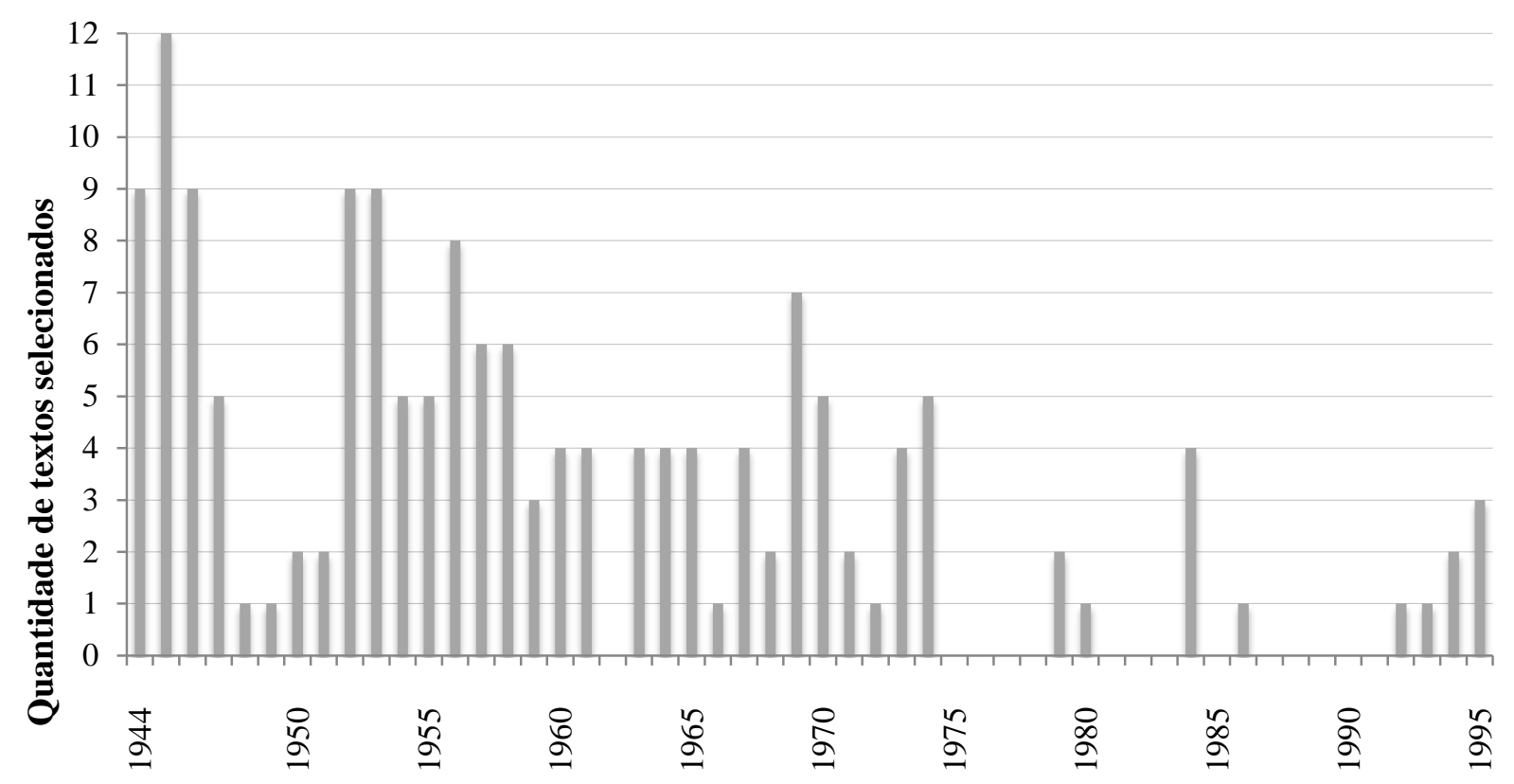

Anos

\footnotetext{
${ }^{16}$ Saviani [2012] refere-se ao Qualis 2012, última avaliação disponível à época de escrita de seu artigo. Vale mencionar, porém, que a classificação da RBEP manteve-se como B1 nos dois últimos rankings da CAPES, realizados em 2013 e 2014.
} 
Como se pode observar, tal distribuição não segue um padrão regular, mas evidencia o que foi afirmado há pouco: a maior parte dos textos selecionados situa-se nas primeiras décadas de existência da revista. Se associarmos essa disposição à conjuntura atravessada pela $R B E P$ e pelo Inep em cada período, é possível compreender, no entanto, que o crivo temático adotado encontrou ressonância maior em determinados momentos.

Entre as várias periodizações possíveis da história da $R B E P$, a proposta por José Carlos Rothen [2005] é bastante abrangente e útil para esse propósito, além de dar conta de alguns dos movimentos aqui já aludidos. Segundo o autor, haveria três grandes fases a serem distinguidas, diretamente relacionadas à história do próprio Inep: entre 1944 e 1951, destacar-se-ia a influência de Lourenço Filho; entre 1952 e 1971, a influência maior teria passado às mãos de Anísio Teixeira; a partir de 1972, a revista teria ingressado em um período oscilante de busca por identidade, período este, por sua vez, subdividido em outras quatro fases (de 1972 a 1975, fortalecimento do Inep como centro de documentação; entre 1976 e 1980, tentativa de desmonte do Inep; entre 1980 e 1995, aproximação da comunidade acadêmica; enfim, a partir de 1996, transformação do Inep em agência de avaliação).

Nesse sentido, a grande concentração da seleção realizada situa-se sob a atuação de Lourenço Filho e de Anísio Teixeira. No outro extremo, o período de maior estiagem a respeito do tema (1975-1991) encontra-se no que Rothen [2005] e outros autores definem como um momento de oscilação da própria revista, coincidindo com a tentativa de desmonte do Inep durante o regime militar e com os anos imediatamente posteriores ao início da redemocratização do país.

É evidente que, por si só, essas associações não explicam a disposição constitutiva do arquivo recolhido, mas são mostra de que fatores de ordem política e administrativa interferem de forma significativa no que se produz e no que se veicula como discurso pedagógico acadêmico a cada época, de modo que não é possível estabelecer uma relação direta e absoluta entre as concentrações e estiagens encontradas e o campo educacional lato sensu. A isso se soma também o fato já aludido de que a própria composição das seções da revista variou bastante ao longo de sua história.

Ainda a esse respeito, uma digressão é necessária. A partir de certos indícios que se fizeram visíveis já na construção do arquivo, formulou-se a hipótese de que aquilo que antes era apontado como potencial caráter educativo de práticas não escolares teria se formalizado como tal posteriormente. Se tal conjectura for correta, será de se supor que 
lá - nas décadas iniciais de publicação da $R B E P$ - estava-se a formular investidas e a projetar modos de vida que hoje nos parecem óbvios. Tão óbvios, embora não evidentes. Há momentos em que o poder parece jogar de forma mais transparente e generalizada. Daí talvez a ideia de que em décadas anteriores falava-se mais em proposições educativas voltadas a elementos diversos do cotidiano, ao passo que, com o passar dos anos, tais proposições, já consolidadas, não mais são evidentes do mesmo modo, mas tão naturalizadas, formalizadas e estabelecidas que parece não haver o que estranhar a respeito.

Quanto à disposição temática, os textos selecionados da RBEP (1944-1995) distribuem-se em um quadro bastante distinto daquele desenhado a partir da outra porção do arquivo, conforme se verá adiante. Isso se justifica tanto pela própria diferença do material encontrado nos dois conjuntos, quanto pela diferença do olhar que orientou cada seleção. A seguir, vejamos um panorama das linhas que puderam ser subtraídas dos 170 textos selecionados da revista.

Em primeiro lugar, as categorias mais gerais. Destas, uma parcela dos escritos situase no grupo das definições: trata-se de escritos majoritariamente teóricos e destinados a estabelecer ou discutir especificidades do campo educacional, em geral discorrendo sobre os alcances, as funções e os ideais do trabalho educativo, bem como sobre as nuanças existentes entre as várias modalidades de educação. O interesse aí se justifica pelo fato de essa discussão apresentar parâmetros daquilo que se considera interno, ou não, ao campo educacional -questão de destaque quando se trata de pensar a educação para fora de seus limites institucionais mais imediatos.

Há os textos que se caracterizam pela função de apresentar diagnósticos da realidade educacional brasileira. Nesse grupo situa-se sobretudo a seção de documentação da revista, onde estavam alocadas mensagens presidenciais com referência à educação, discursos de posse de ministros e demais cargos públicos da área, além de atas e documentos derivados de conferências e eventos sobre o tema. $\mathrm{Na}$ maioria das vezes, tais textos arrematam o diagnóstico feito com a oferta de diretrizes redentoras - escolares ou não.

De cariz semelhante é o bloco de artigos a respeito de educação e novas configurações sociais. Se também discorrem sobre aspectos de conjuntura, tal como os anteriores, estes, contudo, põem ênfase em transformações observadas no contexto social mais amplo, procurando discutir o papel da educação perante as novas demandas apontadas. 
Alguns textos desse bloco estão concomitantemente vinculados a um outro conjunto de escritos, a depender da leitura que fazem de tais transformações: referimo-nos à categoria aqui denominada crise da educação. A necessidade de isolar a porção do arquivo a esse respeito deve-se à evidente centralidade que o tema adquiriu na formulação dos argumentos da pesquisa.

Especificamente em torno da instituição escolar situam-se duas outras vertentes do material, cujos títulos são suficientemente elucidativos: defesa da escola e reforma da escola. Com distinções sutis entre um grupo e outro, o que aí está em questão é a salvaguarda da esfera escolar como locus privilegiado da ação educativa, ainda que, em alguns casos, aponte-se para a necessidade de sua reestruturação.

Em uma direção distinta dessa estão os textos que concentram suas asserções justamente no exterior escolar. Conforme suas particularidades, alguns deles foram divididos nos seguintes blocos: educação popular, educação ao longo da vida e desescolarização. Trata-se de categorias menores em abundância, já que deveras específicas, mas que foram consideradas relevantes como unidades analíticas.

Com discussões a essas avizinhadas, há ainda outros dois grupos de textos, ambos de maior recorrência e de caráter mais abrangente. De um lado, aqueles explícita e literalmente dedicados a uma reflexão sobre a educação não escolar; de outro, aqueles que se propuseram a discorrer sobre funções educativas de dispositivos não escolares. O critério de distinção aí, embora sutil, mostrou-se relevante diante das características do material: no segundo grupo, não se sustenta a ideia de uma educação não escolar como modalidade; antes, apenas são apontadas propriedades educativas de instâncias como a televisão, o rádio, o museu, o parque, entre outras.

De presença muito marcante entre os textos selecionados foram aqueles agrupados sob a temática educação e formação do cidadão. Fazem parte dessa abrangente categoria discussões alusivas às relações da educação com tópicos como cidadania, nacionalismo, civilização, cultura e democracia.

Por fim, há ainda um pequeno bloco de textos que se detiveram sobre a própria $R B E P$ - sua história e suas diretrizes, bem como bibliografias a seu respeito. ${ }^{17}$ Embora não

\footnotetext{
${ }^{17}$ No referido bloco de textos estão artigos cuja publicação é posterior ao período em que a RBEP foi analisada isoladamente dos demais periódicos (1944-1995). É o caso de BRITTO [2012], ROTHEN [2005] e SAVIANI [2012]. Apesar do descompasso temporal, entretanto, julgou-se que tais textos encaixavam-se mais propriamente nessa porção do arquivo (que permite um autorreferenciamento ao próprio suporte da revista), já
} 
seja esta uma temática alinhada às demais, é por compreender a fonte da pesquisa como uma peça performativa que interessava também, em certa medida, o que nela há de metadiscurso.

\subsection{4 periódicos educacionais}

Eleger a classificação Qualis CAPES como critério de seleção dos periódicos implica, claro está, a lida com o fato de que as publicações acadêmicas estão sempre - e cada vez mais - à mercê de parâmetros cambiantes e contingentes de avaliação. Não foi em busca de representantes de uma suposta legitimidade científica, portanto, que tal escolha se deu. ${ }^{18}$ Antes - dentre os vários critérios sempre algo arbitrários a que se pode recorrer -, tratou-se apenas de agrupar um conjunto suficientemente amplo de periódicos que garantisse um quantum significativo de circulação e de permeabilidade aos diversos debates e estudos levados a cabo em instituições e contextos variados do país.

Como se trata agora de um agrupamento massivo a ser investido de um proceder distinto daquele endereçado à $R B E P$, não se justifica uma contextualização individualizada como aquela a ela referida. Em vez disso, as informações são tratadas agora de modo mais panorâmico - quantitativo, inclusive.

O cenário resultante dessa primeira seleção geral pode ser observado no quadro seguinte, que dispõe as instituições responsáveis por cada periódico e seus respectivos anos de criação.

Quadro 1: 34 periódicos nacionais selecionados para a pesquisa

\begin{tabular}{|l|l|c|}
\hline \multicolumn{1}{|c|}{ Periódico } & \multicolumn{1}{|c|}{ Instituição responsável } & $\begin{array}{c}\text { Ano de } \\
\text { lançamento }\end{array}$ \\
\hline Acta Scientiarum. Education & UEM (PR) & 2010 \\
\hline Cadernos CEDES & Unicamp (SP) & 1980 \\
\hline
\end{tabular}

que os artigos considerados a partir de 1996 limitam-se a temáticas não escolares. Daí eles estarem incluídos seção 1 das fontes, ao final do trabalho.

${ }^{18}$ Nesse sentido, não houve qualquer intenção de referendar a avaliação que vem sendo feita dos periódicos inseridos na plataforma da pela Capes, mas apenas de reconhecer o efeito retroalimentativo de tais categorizações valorativas, sem perder de vista o que nelas há de questionável.

${ }^{19}$ Alguns periódicos foram criados posteriormente a 1996, ano estabelecido como primeiro limite do recorte temporal desta porção do material. Nesses casos, obviamente, eles tiveram todos os seus fascículos considerados. 


\begin{tabular}{|c|c|c|}
\hline Cadernos de Educação & UFPel (RS) & 1992 \\
\hline Cadernos de Pesquisa & Fundação Carlos Chagas (SP) & 1971 \\
\hline Contrapontos & Univali (SC) & 2001 \\
\hline Currículo sem Fronteiras & -20 & 2001 \\
\hline E-Curriculum & PUC-SP (SP) & 2005 \\
\hline Educação (PUC-RS) & PUC-RS (RS) & 1978 \\
\hline Educação (UFSM) & UFSM (RS) & 1970 \\
\hline Educação \& Realidade & UFRGS (RS) & 1976 \\
\hline Educação \& Sociedade & Unicamp (SP) & 1978 \\
\hline Educação e Cultura Contemporânea & Universidade Estácio de Sá (RJ) & 2004 \\
\hline Educação e Pesquisa ${ }^{21}$ & $\mathrm{USP}(\mathrm{SP})$ & 1975 \\
\hline Educação em Foco (UEMG) & UEMG (MG) & 1997 \\
\hline Educação em Foco (UFJF) & UFJF (MG) & 1993 \\
\hline Educação em Revista & UFMG (MG) & 1985 \\
\hline Educação em Questão & UFRN (RN) & 1987 \\
\hline Educação Temática Digital & Unicamp (SP) & 1999 \\
\hline Educação Unisinos ${ }^{22}$ & Unisinos (RS) & 1997 \\
\hline Educar em Revista & UFPR (PR) & 1984 \\
\hline Em Aberto & Inep (DF) & 1981 \\
\hline Inter-Ação & UFG (GO) & 1975 \\
\hline Linhas Críticas & $\mathrm{UnB}(\mathrm{DF})$ & 1995 \\
\hline Perspectiva & UFSC (SC) & 1983 \\
\hline Práxis Educativa & UEPG (PR) & 2006 \\
\hline Pro-Posições & Unicamp (SP) & 1990 \\
\hline Revista Brasileira de Educação & ANPEd (RJ) & 1995 \\
\hline Revista Brasileira de Estudos Pedagógicos & Inep (DF) & 1944 \\
\hline Revista da FAEEBA & $\mathrm{UNEB}(\mathrm{BA})$ & 1992 \\
\hline Revista de Educação Pública & UFMT (MT) & 1992 \\
\hline Revista de Educação PUC-Campinas & PUC-Campinas (SP) & 1996 \\
\hline Revista Diálogo Educacional & PUC-PR (PR) & 2000 \\
\hline
\end{tabular}

\footnotetext{
${ }^{20}$ Diferentemente das demais, a revista Currículo sem Fronteiras não está vinculada a nenhuma instituição brasileira específica. Seus fundadores e atuais editores, todavia, são pesquisadores filiados a três universidades distintas: University of Massachusetts, UFRGS e UFPel.

${ }^{21}$ Sob o título de Revista da Faculdade de Educação até 1999.

${ }^{22}$ Sob o título de Estudos Leopoldenses até 1999.
} 


\begin{tabular}{|l|l|l|}
\hline Revista Ibero-Americana de Estudos em Educação & $\mathrm{UNESP}(\mathrm{SP})$ & 2006 \\
\hline Teias & $\mathrm{UERJ}(\mathrm{RJ})$ & 2000 \\
\hline
\end{tabular}

Como se pode ver, os periódicos estão alocados em instituições distintas distribuídas pelos estados brasileiros. Tal distribuição, contudo, é desigual, como também o é, aliás, a própria produção acadêmica. À parte a Região Norte, as outras quatro regiões do país apareceram na seguinte disposição, em ordem decrescente: 15 periódicos estão sediados na Região Sudeste (sendo 9 em São Paulo, 3 em Minas Gerais e 3 no Rio de Janeiro); 11 deles na Região Sul (sendo 5 no Rio Grande do Sul, 4 no Paraná e 2 em Santa Catarina); 5 na Região Centro-Oeste (sendo 3 no Distrito Federal, 1 em Goiás e 1 em Mato Grosso); e 2 na Região Nordeste (sendo 1 no Rio Grande do Norte e 1 na Bahia). Há, ainda, o caso da revista Currículo sem Fronteiras, que não se vincula explicitamente a nenhuma instituição, mas que, se considerada a filiação institucional de seus editores, poderia ser incluída nos cálculos da Região Sul. Tal foi o panorama geral de publicações que se ofereceram à análise. Era preciso, então, apará-lo a fim de compor um arquivo específico.

A triagem e a seleção do material ${ }^{23}$ consistiram, primeiramente, em uma imersão nos títulos, nos resumos e nas palavras-chave ${ }^{24}$ de todos os artigos publicados entre 1996 e 2015. A opção por tal estratégia - mais morosa e precisa do que a busca por descritores - deu-se sobretudo devido à natureza do intento investigativo em tela. Como se tratava justamente de inventariar as formas de apreensão da educação não escolar ao longo do período, bem como os diversos campos e temas por elas investidos, não era possível traçar de antemão uma lista de termos a serem rastreados. Ademais, a própria noção de educação não escolar é aqui assumida como uma classificação analítica a posteriori, ou seja, como uma designação que atribuímos a determinadas práticas, teorizações e proposições a partir de uma definição específica elaborada conforme uma hipótese de pesquisa. Quer isso dizer que muitas vezes os

\footnotetext{
${ }^{23}$ A esse respeito, vale uma menção a título de reconhecimento e de gratidão. A demasiada extensão das fontes e sua ampliação ao longo da pesquisa implicou dificuldades inevitáveis. Isso porque, embora vários periódicos já disponibilizem suas edições por via eletrônica, ainda há uma grande parte desse material cujo acesso só é possível pela via impressa; acrescem-se a isso os fatos de que alguns fascículos são raros e de que não se encontram todos em um mesmo acervo. Assim, ao longo do tempo em que esta pesquisa se efetuou, a tarefa desmedida de reunir informações elementares (títulos, autores, resumos e palavras-chave) de cada um dos artigos publicados nas últimas décadas por esses 34 periódicos (no total de 1.505 fascículos) acabou por se tornar coletiva, ocupando esforços de todo o grupo de pesquisa a que este trabalho se vincula e produzindo, enfim, um acervo compartilhado. Sem dúvida, o que aqui se apresenta não teria sido possível sem esse valioso trabalho conjunto.

${ }^{24}$ Faz-se necessário explicitar que, em parte considerável dos artigos, seus respectivos resumos e palavras-chave não são suficientemente elucidativos do material que visam apresentar. Daí ter sido preciso recorrer, em muitos casos, à leitura do texto completo já nessa triagem inicial do material.
} 
artigos não traziam consigo uma autodenominação nesse sentido, sendo necessário atribuirlhes tal identificação. Assim, tampouco a expressão educação não escolar - ou não formal era adequada para uma busca na massa discursiva informe de que se dispunha.

Foram recolhidos, enfim, 760 artigos, distribuídos entre os periódicos conforme o quadro a seguir.

Quadro 2: Quantidade de fascículos publicados e de artigos selecionados por periódico

\begin{tabular}{|c|c|c|}
\hline Periódico & $\begin{array}{c}\text { Fascículos publicados } \\
\quad(1996-2015)\end{array}$ & Artigos selecionados \\
\hline Acta Scientiarum. Education & 14 & 4 \\
\hline Cadernos CEDES & 59 & 50 \\
\hline Cadernos de Educação & 47 & 16 \\
\hline Cadernos de Pesquisa & 63 & 15 \\
\hline Contrapontos & 45 & 24 \\
\hline Currículo sem Fronteiras & 34 & 17 \\
\hline E-Curriculum & 27 & 23 \\
\hline Educação $(P U C-R S)$ & 60 & 19 \\
\hline Educação (UFSM) & 48 & 19 \\
\hline Educação \& Realidade & 50 & 19 \\
\hline Educação \& Sociedade & 80 & 9 \\
\hline Educação e Cultura Contemporânea & 17 & 12 \\
\hline Educação e Pesquisa & 58 & 14 \\
\hline Educação em Foco (UEMG) & 26 & 8 \\
\hline Educação em Foco (UFJF) & 39 & 13 \\
\hline Educação em Revista & 50 & 40 \\
\hline Educação em Questão & 43 & 14 \\
\hline Educação Temática Digital & 46 & 30 \\
\hline Educação Unisinos & 48 & 37 \\
\hline Educar em Revista & 57 & 41 \\
\hline Em Aberto & 26 & 18 \\
\hline Inter-Ação & 39 & 17 \\
\hline Linhas Críticas & 41 & 24 \\
\hline Perspectiva & 47 & 24 \\
\hline Práxis Educativa & 21 & 9 \\
\hline
\end{tabular}




\begin{tabular}{|l|c|c|}
\hline Pro-Posições & 59 & 25 \\
\hline Revista Brasileira de Educação & 62 & 34 \\
\hline Revista Brasileira de Estudos Pedagógicos & 47 & 14 \\
\hline Revista da FAEEBA & 40 & 44 \\
\hline Revista de Educação Pública & 54 & 51 \\
\hline Revista de Educação PUC-Campinas & 42 & 13 \\
\hline Revista Diálogo Educacional & 46 & 17 \\
\hline Revista Ibero-Americana de Estudos em Educação & 32 & 21 \\
\hline Teias & 38 & 25 \\
\hline
\end{tabular}

Mais uma distribuição desigual, pois: de 4 a 51 vão as quantidades de artigos selecionados a partir de cada periódico. Mas tais números absolutos, em si, não dizem muita coisa, já que também é variável a quantidade de fascículos veiculados por cada publicação no período, devido tanto ao fato de algumas delas terem sido criadas mais recentemente do que outras, quanto à diferença em suas respectivas periodicidades. Daí a necessidade de um cálculo mais específico para que se possa avaliar a predominância do tema relativamente à soma de edições veiculadas. Nesse sentido, em números proporcionais, pode-se dizer que os seguintes periódicos destacam-se no topo da relevância concedida aos artigos em torno de uma educação não escolar, por ordem decrescente: Revista da FAEEBA, Revista de Educação Pública e E-Curriculum. No polo oposto, com a menor relevância, encontram-se: Educação \& Sociedade, Educação e Pesquisa e Cadernos de Pesquisa.

No caso particular da Revista da FAEEBA, a grande relevância proporcional de artigos encontrados talvez se justifique pelos assuntos que vêm sendo propostos nas seções temáticas da revista, constantes de todas as edições. Entre elas, vale mencionar algumas mais recentes: educação popular (2015); educação e ruralidades (2013); educação indígena (2010); educação ambiental e sociedades sustentáveis (2007); educação e trabalho (2006); educação e novas tecnologias (2004) - todos eles temas que abrem espaço a reflexões e práticas não escolares. Ainda assim, tal relação presta-se apenas a título especulativo, já que temáticas similares também são por vezes propostas nos demais periódicos.

Já a Revista de Educação Pública tem seu conteúdo dividido em seções temáticas fixas, entre as quais se incluem educação e meio ambiente (presente em todo o intervalo temporal analisado) e movimentos sociais (existente como seção isolada da revista até 2002), 
o que corrobora tanto o destaque que o periódico representou no arquivo, quanto a recorrência temática em torno desses dois eixos, conforme se verá mais adiante.

Quanto à distribuição temporal dos artigos, observemos o seguinte gráfico:

Gráfico 2: Distribuição dos artigos selecionados por ano (1996-2015)

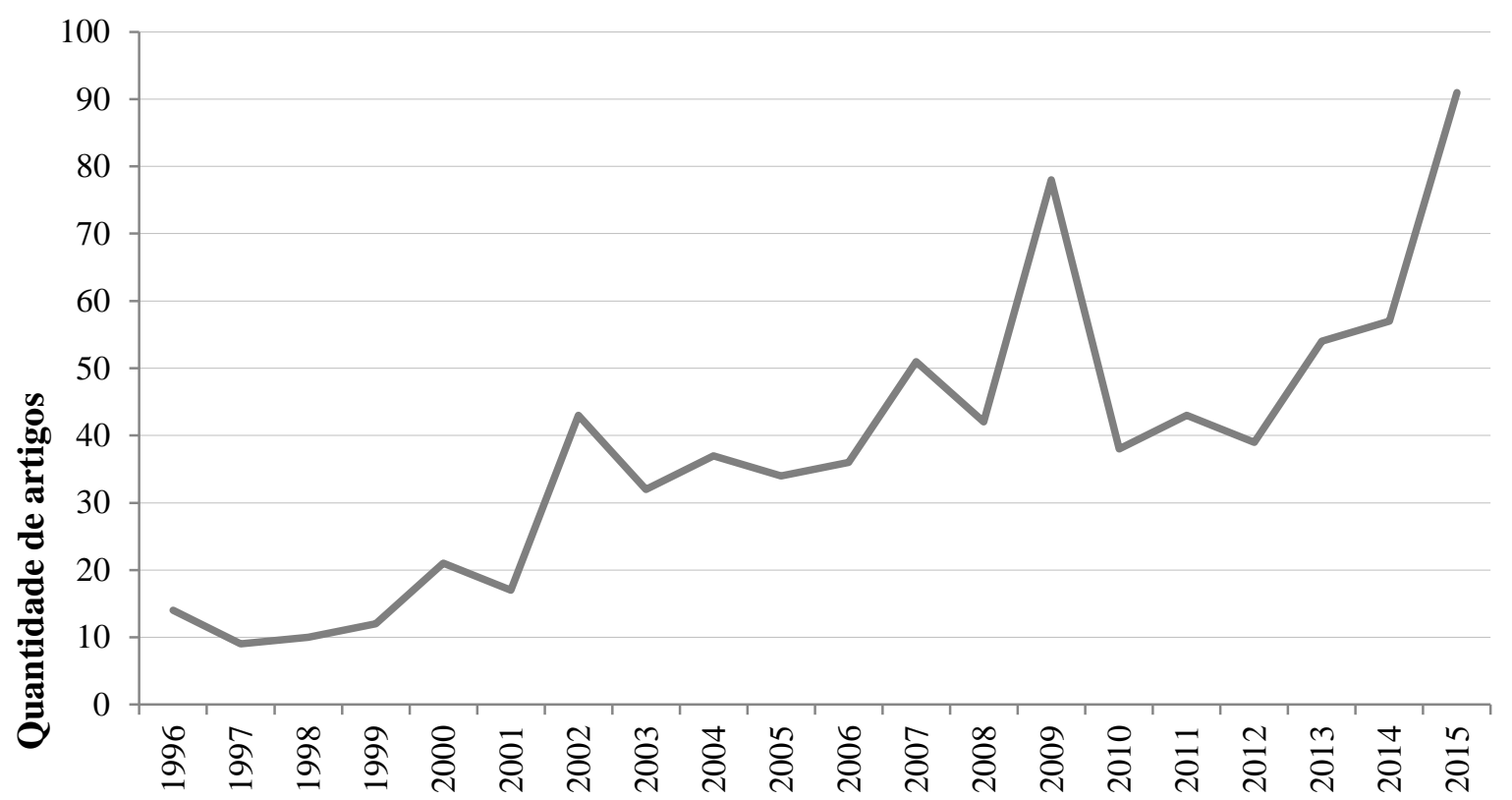

Anos

Em termos absolutos, é possível aí observar um aumento de incidência no decorrer dos anos, com algumas oscilações. Mas a curva produzida por esses dados não se mostra tão relevante se tivermos em conta que também o volume de publicações aumentou progressiva e consideravelmente no mesmo período. Quanto ao pico observado em 2009, é de se mencionar que houve naquele ano a publicação de dossiês dedicados a temáticas avizinhadas à da educação não escolar, o que justifica o aumento significativo de artigos encontrados no período. Foram eles: uma edição de E-Curriculum constituída por apresentações de pesquisas sobre trabalhos acadêmicos realizados entre 1998 e 2006 acerca da temática da educação não escolar de jovens e adultos; uma edição de comemoração de 25 anos de Educação em Revista, que contou com um dossiê sobre educação ambiental; uma edição de Cadernos CEDES dedicada à intersecção entre os temas educação popular e saúde.

No que concerne à autoria dos artigos, sete pesquisadores evidenciaram destaque quanto à recorrência, seja assinando textos sozinhos, seja em coautoria. São eles: Danilo Romeu Streck, pesquisador ligado à Unisinos, com nove artigos selecionados a respeito de educação popular; Maria Clara Bueno Fischer, pesquisadora ligada à UFRGS, com oito 
artigos selecionados a respeito de educação e trabalho; Dinora Tereza Zucchetti e Eliana Moura, ambas ligadas à Universidade Feevale, com seis artigos em coautoria selecionados sobre aspectos conceituais da educação não escolar; Michèle Sato, pesquisadora vinculada à UFMT, com seis artigos selecionados a respeito de educação ambiental; Lia Tiriba, pesquisadora vinculada à UFF, com cinco artigos selecionados sobre educação e trabalho; e Telmo Adams, pesquisador ligado à Unisinos, com cinco artigos selecionados em torno de educação popular e trabalho. A porção majoritária dos autores (889 de um total de 1.006), no entanto, comparece na seleção com apenas um artigo publicado, o que denota haver dispersão das temáticas não escolares em grupos e instituições de pesquisa.

É tempo de apresentar o modo como os artigos foram reagrupados em conjuntos menores. Desprovidas de classificações apriorísticas, como já se disse, as possibilidades de organização do material emanaram de seu próprio manuseio. ${ }^{25}$ Por isso, cumpre ressaltar que os tópicos selecionados não correspondem à porção integral de seu aparecimento nos periódicos. É o caso, por exemplo, da educação ambiental, uma das temáticas mais recorrentes, como se verá adiante. Os artigos a esse respeito muitas vezes restringiam seu alcance ao contex to escolar, discutindo ou propondo iniciativas relativas à temática ambiental aplicadas a disciplinas e atividades escolares. Tais textos, obviamente, não foram incluídos no arquivo, pois, embora estivessem alinhados a um tema afim, não cumpriam o requisito fundamental de se centrarem explicitamente fora do contexto escolar. ${ }^{26}$

Tendo essa distinção em mente, os artigos selecionados foram classificados conforme 27 eixos temáticos, de modo a possibilitar um panorama geral das subáreas correlatas, por meio do qual desponta um retrato extensivo da diversidade de temas que têm sido investidos atualmente por iniciativas educacionais não escolares. Os eixos por vezes aparecem combinados em um mesmo texto (por exemplo, quando um artigo discorre sobre a função educativa de um programa televisivo direcionado a crianças, ele foi classificado como

\footnotetext{
${ }^{25}$ Alguns autores já propuseram classificações a partir de critérios preestabelecidos. Jaume Trilla Bernet (2003), por exemplo, apresenta um quadro taxonômico realmente completo de ofertas educativas não escolares, definindo categorias quanto a finalidade, função, localização, grupo de educandos, conteúdos, modos de financiamento e de avaliação, tempo e espaço de atuação, entre outros aspectos envolvidos em tais iniciativas. Já Marcos Francisco Martins (2016) parte de uma análise de cunho filosófico, categorizando os processos educativos não escolares em tendências (tradicional, científico-tecnicista, humanista-existencial, históricodialética e pós-moderna) com base em seus aspectos ontológicos, antropológicos, epistemológicos e axiológicos. Embora tais propostas de ordenação possam ser de grande valia, a intenção da análise foi subtrair do próprio arquivo os eixos que nele adquiririam realce, sem recorrer a definições previamente fixadas.

${ }^{26}$ No mesmo sentido, discussões ligadas ao âmbito específico da educação a distância não foram incluídas, já que na maioria das vezes referem-se a uma extensão anunciada do próprio âmbito educativo formal, embora se utilizem de meios extraescolares.
} 
educação e mídia e, concomitantemente, como educação e infância), de forma que sua contabilização não corresponde, numericamente, à soma dos artigos selecionados. De todo modo, a preferência deu-se no sentido de classificá-los de acordo com a temática imediatamente mais central. Ademais, vale mencionar que alguns focos temáticos foram considerados por fazerem eco a discussões encontradas na primeira porção do arquivo $(R B E P)$, a despeito de sua reduzida recorrência no período entre 1996 e 2015.

A tarefa de classificação demandou, sem dúvida, arbitrar um imenso aglomerado de eixos temáticos que bem poderiam estar dispostos de outro modo, compondo outras ramificações. Tarefa impossível seria buscar univocidade de sentido na algaravia discursiva composta por autores, temas, contextos e suportes em nada convergentes. Todavia, a intenção foi a de traçar um quadro que se mantivesse permeável às idiossincrasias do material.

A seguir estão listados os 27 eixos temáticos elencados, bem como uma breve descrição do que cada um deles compreendeu. Quando necessário, as notas justificam mais propriamente os critérios utilizados em cada caso.

- educação e infância: compreende processos educativos diretamente voltados para o público infantil, englobando projetos urbanos específicos, bem como aprendizagens em situações de brincadeira, em programas televisivos e em outros contextos;

- educação e juventude: reflexões que têm nos jovens seu principal alvo de atenção, seja em relação a tópicos como sexualidade, ambiente virtual, mídia televisiva e projetos socioeducativos, seja em relação a dimensões educativas de experiências como escotismo e acampamento;

- educação de jovens e adultos: ${ }^{27}$ práticas educativas especificamente direcionadas ao público jovem e adulto, em geral subsumidas na modalidade (por vezes também escolar) da Educação de Jovens e Adultos (EJA) e relacionadas a preocupações laborais;

- educação e velhice: refere-se a práticas de cunho educacional direcionadas especificamente ao público idoso;

\footnotetext{
${ }^{27}$ Apesar de alguma redundância entre este e o eixo anterior, referente à juventude, a divisão justifica-se devido aos próprios termos utilizados nos textos: em geral, iniciativas práticas ou reflexivas voltadas à idade adulta são expressas pela díade jovens e adultos e raramente aparecem isoladas, enquanto aquelas exclusivamente voltadas à juventude adotam terminologia mais específica.
} 
- educação e cidade: inclui estudos voltados à educação no contexto difuso das cidades e tópicos mais específicos relativos a aparatos urbanos (por exemplo, educação em parques); não contempla, entretanto, casos em que a questão social é alvo predominante do artigo, embora o contexto também seja urbano (por exemplo, projetos socioeducativos destinados ao público em situação de rua que não apresentam reflexão específica sobre a questão urbana);

- educação no campo: artigos dedicados aos processos educativos que ocorrem em contexto campesino, seja em relação a aprendizagens ali possíveis de forma acidental, seja em relação a projetos intencionalmente educativos;

- educação em prisões: compreende a dimensão educativa presente em contexto carcerário, tanto no que se refere a processos incidentais, quanto no que se refere a programas de reinserção social e de promoção da leitura entre o público presidiário;

- educação em museus: inclui programas educacionais e materiais pedagógicos desenvolvidos para ambientes museais (sobretudo em relação a áreas como ciências e história), bem como outros processos educativos possíveis em tais contextos;

- educação em hospitais: abrange iniciativas educativas alocadas em hospitais e enfermarias (em geral relativas ao que se denomina classe hospitalar), bem como processos educativos não intencionais que podem ocorrer em ambientes hospitalares;

- educação e família: refere-se ao tema geral da educação ocorrida em contexto familiar, compreendendo tópicos como maternidade e práticas parentais, além de reflexões sobre a função educativa da família;

- educação e mídia: questões educacionais relativas a meios de comunicação de massa (seja de modo intencional ou acidental, sejam práticas fomentadas pela mídia, seja ainda uma educação voltada para a mídia), compreendendo televisão, imprensa, rádio e cinema;

- educação e tecnologia: ${ }^{28}$ compreende as relações entre educação e uso de tecnologias digitais/virtuais, abrangendo temas como educação online, tecnologias da informação e comunicação (TIC), ambientes virtuais e inclusão digital;

\footnotetext{
${ }^{28}$ Embora os meios aqui referidos também pudessem estar inclusos na categoria anterior, optou-se por considerá-los separadamente devido a especificidades relevantes aí presentes, como seu caráter mais recente e a interatividade que pressupõe. Ademais, uma vez que tais tecnologias não estavam disponíveis à época considerada na primeira porção do arquivo (1944-1995), julgou-se importante considerá-las à parte.
} 
- educação indígena: abarca os processos educativos que se passam no interior da cultura indígena, envolvendo transmissão intergeracional e reivindicações em torno do tema;

- educação e cultura: casos em que a reflexão central se dá em torno da função educativa da cultura, seja esta tomada em um sentido amplo ou em eixos específicos (por exemplo, cultura popular, cultura caipira, cultura musical); também abarca tópicos como multiculturalismo e afins;

- educação e esporte: compreende os processos educativos possíveis de ocorrência em contextos esportivos, bem como a utilização de jogos e demais atividades esportivas como ocasião educativa;

- educação e meio ambiente: inclui a temática geral da educação ambiental e tópicos mais específicos, como preservação animal, educação em zoológicos, sustentabilidade, consumo sustentável e agroecologia, além de textos sobre estados da arte referentes ao tema;

- educação e movimentos sociais: considera tanto a temática da educação que se passa no interior dos movimentos sociais organizados, quanto demandas educativas apresentadas por esses movimentos;

- educação e assistência: trata da educação voltada a questões sociais (marginalidade, exclusão, pobreza, criminalidade), situação de rua e instituições de abrigo, ou seja, iniciativas educacionais relativas a finalidades de assistência social;

- educação e religião: inclui tanto a educação propriamente religiosa, quanto iniciativas educativas alocadas em contextos religiosos;

- educação e saúde: práticas de teor educativo direcionadas à promoção da saúde, à conscientização e à prevenção de doenças, bem como tópicos específicos, como educação sexual e do corpo;

- educação e lazer: ocupa-se das possibilidades educativas em espaços e tempos permeados por atividades de lazer, sejam elas turísticas, lúdicas, esportivas ou culturais;

- educação e trabalho: textos que abordam tanto a função educativa do trabalho (e dos processos pedagógicos que se passam no contexto laboral), quanto iniciativas intencionais de cunho pedagógico voltadas a trabalhadores;

- educação popular: inclui textos devotados a questões não escolares próprias às modalidades educativas sob a concepção de uma educação popular, esta circunscrita como modalidade teórico-metodológica específica do campo pedagógico; 
- educação permanente: trata de práticas e proposições especificamente alinhadas à orientação de uma formação continuada e ao longo da vida;

- educação nacional: temática recorrente nos conteúdos veiculados pela $R B E P$ ao longo das primeiras décadas de suas publicações, foi isolada também nessa porção do arquivo, embora aqui tenha apresentado menor destaque;

- formação e atuação profissional: inclui casos que se debruçam sobre a formação de quadros profissionais específicos para exercício em contextos de educação não escolar, discutindo tanto a entrada desse campo de atuação nos currículos dos cursos de pedagogia e a ausência de formação própria para a função, quanto as competências necessárias a serem desenvolvidas;

- educação não escolar: considera os artigos que explicitamente têm suas discussões centradas na temática da educação não escolar, incluindo reflexões teóricas sobre o assunto, críticas, definições terminológicas e proposições.

Se a classificação levada a cabo decerto não logrou oferecer uma listagem mais sintética dos principais temas, contextos e vieses que permearam os artigos, isso também se deveu à intenção de esmiuçar os achados mais pelo detalhe do que por uma economia representativa. Nesse sentido, a ampla paleta de eixos identificados acaba por ser, ela própria, evidência de alguma dispersão de atribuições educacionalizantes aos mais diversos enquadres da organização societária contemporânea.

A partir de um segundo esforço de classificação, foi possível agrupar as regiões temáticas iniciais em seções mais amplas, as quais acabaram por evidenciar nichos gerais de operação das iniciativas educacionais não escolares que atravessam as páginas dos periódicos. Desta feita, podemos reconhecer que tais iniciativas se expandem rumo a determinadas temporalidades (infância, juventude, idade adulta e velhice), espacialidades (cidade, ambiente familiar, museus, prisões, hospitais, campo, contextos indígenas, suportes mediáticos) e práticas socioculturais (produções culturais, esporte, meio ambiente, movimentos sociais, assistência, religião, saúde, tecnologia, trabalho, lazer), circunscrevendo um campo bastante diversificado de atuação. Daí os três seguintes agrupamentos: educação na extensão da vida; educação na extensão dos espaços cotidianos; educação na extensão das práticas socioculturais. À parte, ainda, é preciso considerar o eixo formação e atuação profissional na educação não escolar, que diz respeito a uma dimensão fundamental das 
discussões em torno da educação não escolar e denota certa expansividade interna ao próprio campo pedagógico.

O tema educação e meio ambiente foi de longe o mais recorrente nas discussões, tendo comparecido em 114 artigos (15\% do total). Ele é seguido por educação e tecnologia (73 artigos), educação e movimentos sociais (71 artigos) e educação e mídia (71 artigos). ${ }^{29} \mathrm{Se}$ tal informação diz respeito à classificação externamente atribuída aos textos pelos procedimentos da pesquisa, é válido considerar também o rol de palavras-chave anunciadas pelos próprios autores. ${ }^{30}$ Quanto a isso, as expressões de maior incidência foram, respectivamente, educação ambiental - confirmando o predomínio do eixo temático correspondente -, educação popular, educação de jovens e adultos e movimentos sociais.

Ao longo dos 20 anos considerados, porém, a distribuição tanto dos eixos temáticos quanto das palavras-chave apresentou variações. Para melhor perspectivá-las, o período total foi subdividido em quatro quinquênios (1996-2000, 2001-2005, 2006-2010, 2011-2015). Os gráficos a seguir apresentam a distribuição desses 27 eixos temáticos no arquivo, tanto na totalidade dos 20 anos considerados (gráfico 3), quanto em cada um de seus subperíodos (gráficos 4, 5, 6 e 7). Também se dispôs em representação gráfica a variação cronológica interna aos eixos temáticos (gráfico 8).

\footnotetext{
${ }^{29}$ É válido observar que, se considerados como um mesmo eixo geral relativo a meios de comunicação, os temas educação e mídia e educação e tecnologia teriam alcançado, juntos, a maior recorrência (19\%).

${ }^{30}$ Uma parcela dos textos, sobretudo no intervalo anterior ao ano 2000, não apresentava palavras-chave, elemento que com o tempo se tornou obrigatório às publicações periódicas. Assim, os artigos sem palavraschave não foram contabilizados nesse quesito.
} 
Gráfico 3: Distribuição dos eixos temáticos no arquivo total (1996-2015)

Educação e meio ambiente

Educação e tecnologia Educação e movimentos sociais Educação e mídia Educação não escolar Educação popular Educação e cultura

Educação e trabalho

Educação de jovens e adultos Educação e saúde Educação e infância

Educação e juventude Atuação e formação profissional Educação e assistência Educação e cidade Educação no campo Educação em museus Educação permanente Educação e religião Educação e família Educação em prisões Educação em hospitais Educação indígena

Educação e lazer Educação e esporte Educação e velhice Educação nacional
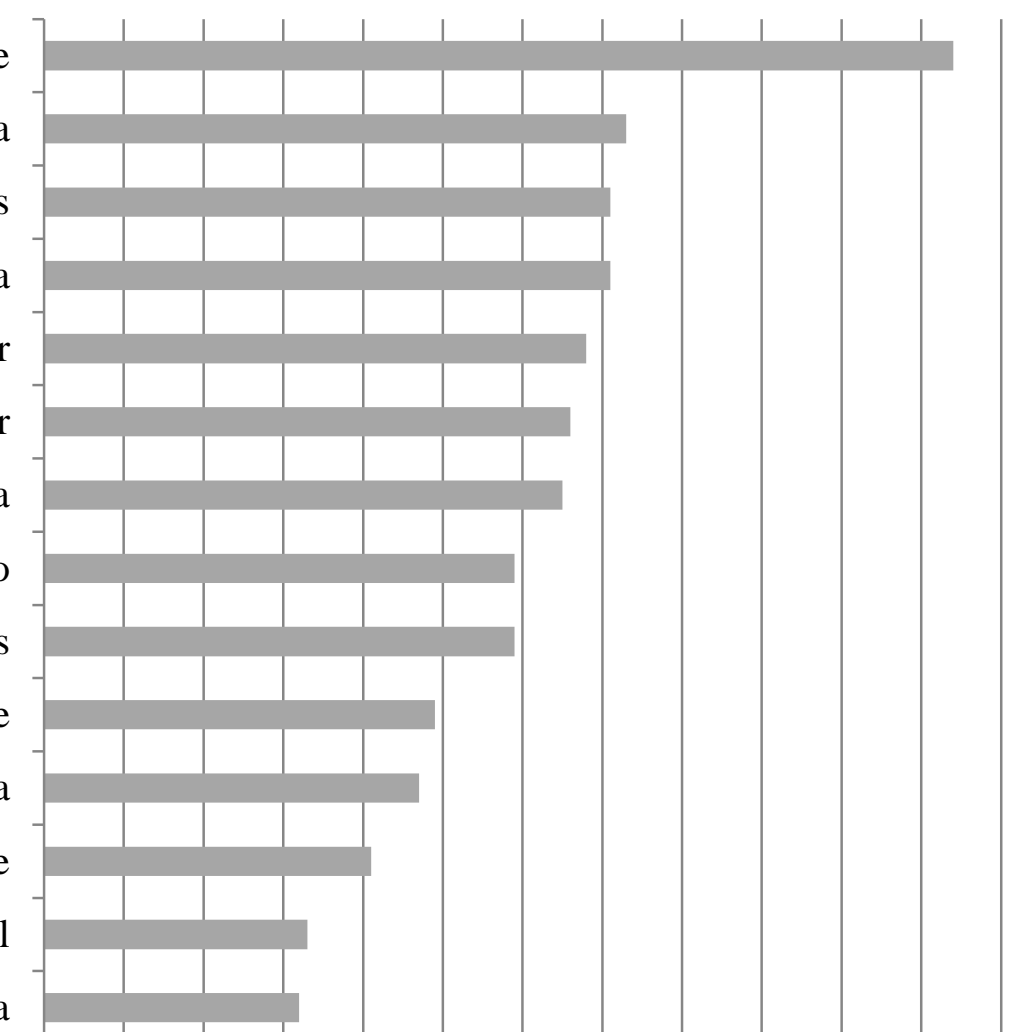

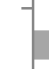
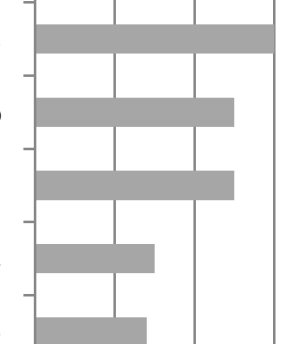
Gráfico 4: Distribuição dos eixos temáticos no $1^{\circ}$ quinquênio (1996-2000)

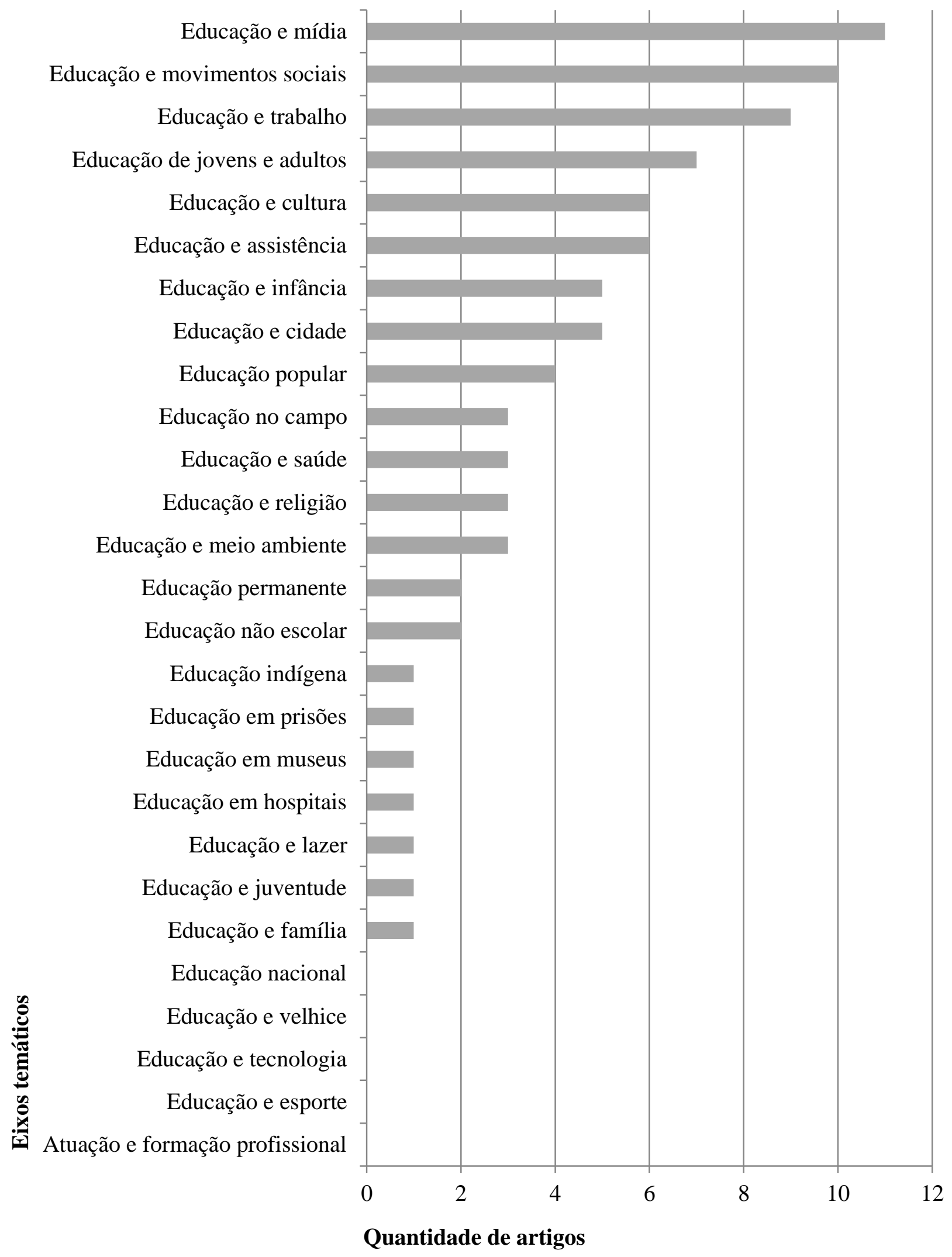


Gráfico 5: Distribuição dos eixos temáticos no $2^{\circ}$ quinquênio (2001-2005)

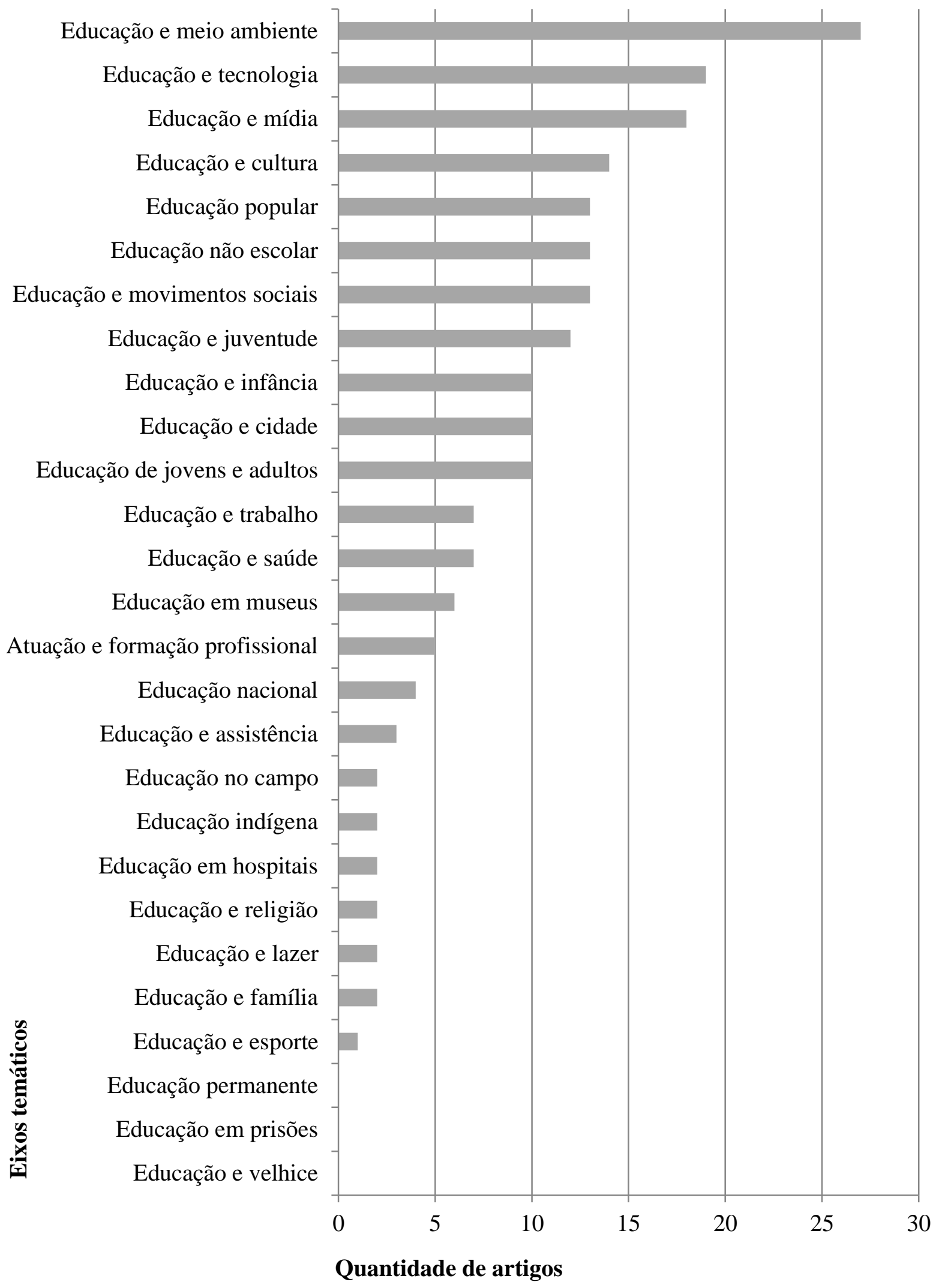


Gráfico 6: Distribuição dos eixos temáticos no $3^{\circ}$ quinquênio (2006-2010)

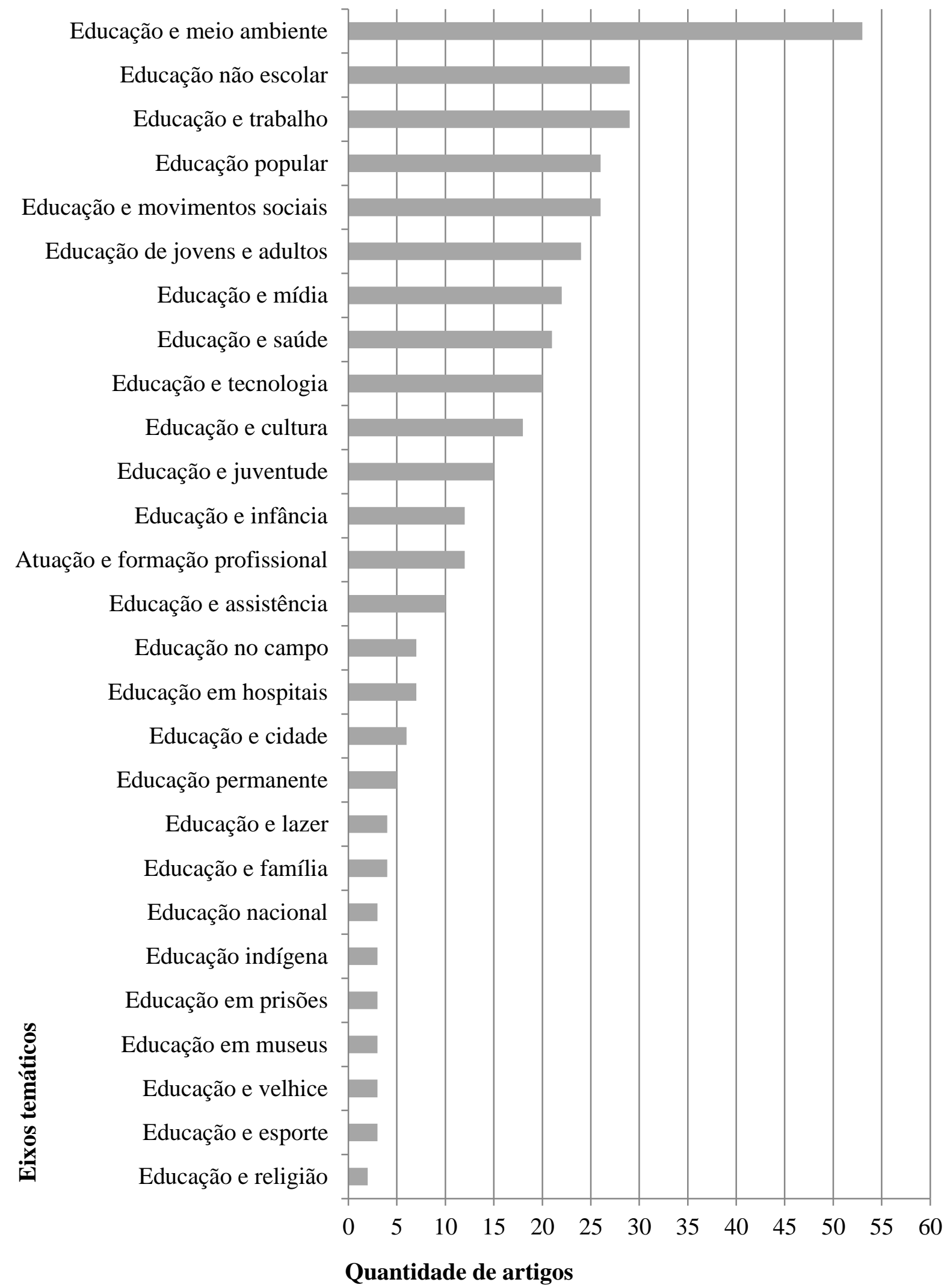


Gráfico 7: Distribuição dos eixos temáticos no $4^{0}$ quinquênio (2011-2015)

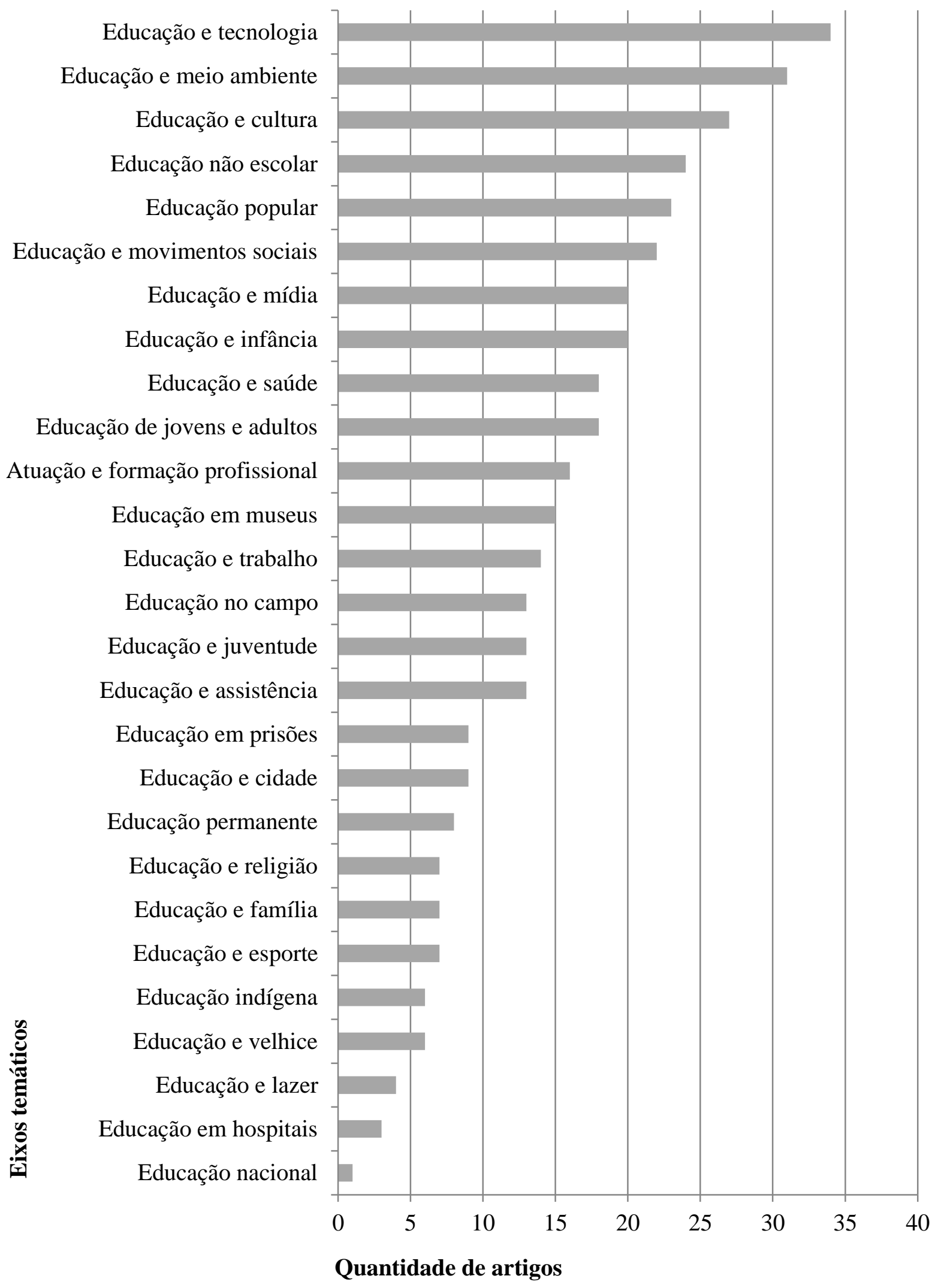


Gráfico 8: Distribuição cronológica interna de cada eixo temático ${ }^{31}$

Educação e meio ambiente

Educação e tecnologia

Educação e movimentos sociais

Educação e mídia

Educação não escolar

Educação popular

Educação e cultura

Educação e trabalho

Educação de jovens e adultos

Educação e saúde

Educação e infância

Educação e juventude

Atuação e formação profissional

Educação e assistência

Educação e cidade

Educação no campo

Educação em museus

Educação permanente

Educação e religião

Educação e família

Educação em prisões

Educação em hospitais

Educação indígena

Educação e lazer

Educação e esporte

Educação e velhice

Educação nacional

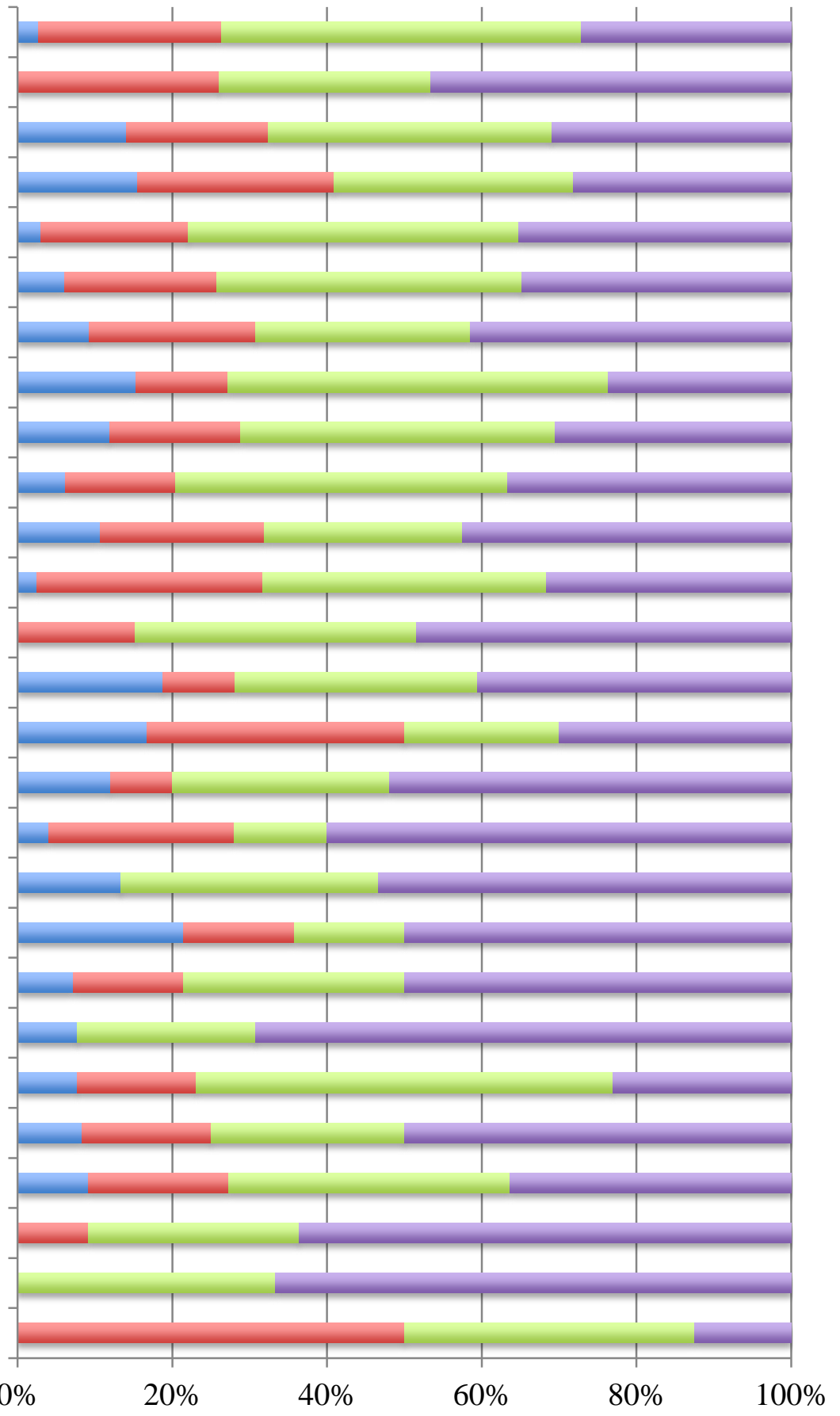

Percentual por período

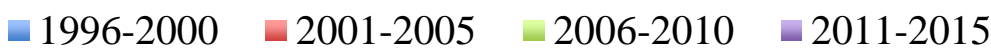

\footnotetext{
${ }^{31}$ Uma advertência: neste gráfico, cada barra representa a totalidade de artigos encontrados em cada eixo temático. Como tais quantidades são variáveis, a comparação possível é apenas interna a cada eixo.
} 
Enquanto alguns temas apresentam um movimento ascendente, adquirindo maior recorrência nos últimos cinco anos, outros, pelo inverso, exibem um fluxo decrescente, demonstrando terem sido mais presentes na porção inicial do período considerado. No primeiro caso, é possível incluir temáticas como educação e tecnologia, atuação e formação profissional, educação em museus, educação no campo, educação permanente, educação e religião, educação e família, educação em prisões, educação indígena, educação e esporte e educação e velhice - todos esses 12 eixos temáticos com 50\%, ou mais, de menções datadas do último quinquênio. Destacam-se aí quatro eixos específicos, cuja distribuição denota uma concentração recente ainda mais proeminente, indicando, talvez, certa ascensão como objeto de reflexão no campo educacional: educação em museus, educação em prisões, educação e esporte e educação e velhice.

Já no outro polo, com fluxo decrescente, o relevo recai sobre o eixo educação nacional, cujas menções se concentram no quinquênio 2001-2005 e se reduzem progressivamente. Demais casos de baixa recorrência recente, comparativamente aos anos anteriores, são ilustrados pelas temáticas educação e trabalho e educação em hospitais.

Se os dois últimos quinquênios apresentam presença de todos os eixos temáticos, a despeito das variações, o mesmo não pode ser dito em relação aos dois primeiros. Com efeito, alguns temas apenas começam a marcar presença efetiva no arquivo a partir de determinado momento. É o caso de educação e tecnologia (que teve sua primeira ocorrência em 2001), atuação e formação profissional (primeira ocorrência também em 2001), educação e esporte (também em 2001), educação e velhice (em 2006), e educação nacional (em 2002). Que esteja claro, entretanto, que essa informação diz respeito somente à seleção feita nesta porção da pesquisa, de modo que ela não se pretende explicativa ou representativa da totalidade da produção acadêmica educacional no país. Apenas a título de exemplo, a temática educação nacional já se fazia muito presente nas publicações da RBEP em meados do século XX.

Quanto às palavras-chave, a variação encontrada acaba por ser elucidativa de alguns movimentos observados. As expressões mais recorrentes em cada quinquênio foram as seguintes: entre 1996 e 2000, educação de jovens e adultos, televisão, cultura e educação de adultos; entre 2001 e 2005, educação ambiental, educação popular, juventude, movimentos sociais e emancipação; entre 2006 e 2010, educação ambiental, educação popular, movimentos sociais, educação de jovens e adultos, juventude; entre 2010 e 2015, educação ambiental, educação popular, educação de jovens e adultos, aprendizagem e movimentos sociais. Mais uma 
vez, portanto, o meio ambiente constitui tópico assíduo a partir de 2001; o eixo em torno dos movimentos sociais também confirma sua recorrência no mesmo período.

Assim se encerraram as várias etapas de preparação do arquivo. Por vezes demasiado esquemáticas ou até enfadonhas, sobretudo para quem as lê, elas foram necessárias para que um universo discursivo tão vasto não se tornasse um labirinto analítico ingovernável. Foram fundamentais, ainda, para que algumas suspeitas tomassem forma quanto às conjecturas iniciais da pesquisa. Isso porque as fontes empíricas haviam sido objeto de uma premissa antecipada, sustentada na expectativa de que a curva resultante de sua análise, em termos quantitativos, deveria ser fundamentalmente crescente.

Se era de um expansionismo pedagógico que então se falava, nada mais provável do que o aumento gradativo (e cada vez mais intenso) de menções a práticas e aparatos educacionais outros que não aqueles sediados na instituição escolar. Aí pressuposta, ainda que implicitamente, persistia a premissa de uma linearidade histórico-cultural, de um progressivismo teleológico em tudo repelente a rupturas e contingências. Mas elas existiam aos borbotões.

Com o findar dos levantamentos, despontou o espanto perante uma recorrência que, não obstante sua dispersão, ora oscilava, ora encolhia, mas raramente ascendia, independentemente de quão perdulário fosse o crivo da triagem - e ele o foi sobremaneira. Ainda hoje, portanto, a temática escolar continua a ocupar majoritariamente as produções acadêmicas veiculadas em tais periódicos.

A leitura que se fez dos textos selecionados, bem como a atenção difusa à infinidade de outros artigos publicados evidenciaram um fenômeno curioso: muitas vezes, uma temática que vinha ganhando realce em artigos propositivos de práticas não escolares passava a ter suas aparições reduzidas até praticamente se tornar imperceptível. Mas reaparecia em outro lugar: nos textos acerca das práticas escolares. ${ }^{32}$ Em vez de rarefação, portanto, incorporação.

\footnotetext{
${ }^{32}$ Embora os textos sobre temáticas propriamente escolares não tenham sido alvo do levantamento levado a cabo nesta pesquisa, ao longo do trabalho de coleta (que acabou envolvendo a leitura da totalidade dos resumos publicados) foi possível entrever alguns movimentos a esse respeito. Trata-se aí, é evidente, de meras impressões que demandariam uma investida de outra ordem, mas que ficam registradas como resíduo analítico e advertência para que não se tome o universo investigado - fundamentalmente restrito - como totalidade representativa.
} 
Com efeito, praticamente todos os eixos temáticos abordados nos escritos sobre educação não escolar têm também seu correlato propriamente escolar.

Ora, estaria a instituição escolar absorvendo, afinal, as demandas materializadas em seu exterior? Ou, então, até que ponto é possível oferecer resistência à escola sem dela se valer como forma-referência? Itens adicionais ao nosso rol de indagações, que a esta altura começa a se tornar intrincado em demasia, decerto.

Diversamente do gesto prolixo que presidiu as várias seleções e classificações, o esforço que se segue é mais da ordem da circunscrição e da parcimônia. Trata-se, agora, de reconhecer deslocamentos, de atribuir movimento a um conjunto de enunciados que, de outro modo, permaneceria estático e incomunicável.

Nesse sentido, circunscrição e parcimônia não foram apenas anseio deliberado do presente esforço analítico, senão condição imposta pela própria massa discursiva que se pretendeu atravessar em busca de traçados genealógicos. Dos 27 eixos temáticos a partir dos quais a educação não escolar se desenha ao longo das últimas duas décadas nas publicações periódicas analisadas, são poucos os que comparecem de maneira significativa nas discussões da RBEP anteriores a 1996. Afora uma ou outra menção pontual, a julgar pelo arquivo constituído, pode-se dizer que a porção majoritária de tais eixos ramificou-se, consolidou-se e proliferou como preocupação delimitada do campo educacional apenas recentemente. No entanto, caminhos pregressos já preparavam solo para que tais investidas fossem hoje acolhidas sem maiores sobressaltos. 


\title{
3. ENREDOS DE UM ACONTECIMENTO
}

Um mapa consiste na representação cartográfica de informações acerca de determinada superfície. Como toda representação, ele se produz por meio de uma redução, ou seja, de uma síntese do que se considera mais indispensável ou relevante a respeito daquela superfície. Sua fidelidade a esta, portanto, é relativa. Não o fosse, seria preciso produzir mapas em dimensões equivalentes ao território que se intenta mapear. Seria preciso, ademais, atualizar o mapeamento a cada instante, levada em conta a mobilidade das superfícies territoriais, em seus múltiplos aspectos.

A esse respeito, é conhecida a ironia de Borges (2000, p. 247) em anedota alusiva à pretensão Do rigor na ciência:

\begin{abstract}
Naquele Império, a Arte da Cartografia logrou tal perfeição que o mapa de uma única Província ocupava toda uma Cidade, e o mapa do império, toda uma Província. Com o tempo, esses Mapas Desmedidos não satisfizeram e os Colégios de Cartógrafos levantaram um Mapa do Império, que tinha o tamanho do Império e coincidia pontualmente com ele.
\end{abstract}

Considerando-se a crítica aí sugerida, a justa aderência às realidades (geográficas, dimensionais, populacionais, arqueológicas etc.) seria incompatível com a elaboração de um mapa. Por extensão de argumento, se não está aderido a um plano único e inequívoco do real, o mapa produz realidades à medida que se delineia - como o faz toda representação, aliás.

O mesmo se pode dizer a respeito de outra modalidade gráfica: o diagrama. Este, no entanto, abriga particularidades importantes em relação ao mapa: em vez de traçar a disposição das unidades de uma superfície, ele evidencia fluxos e relações entre elementos distintos.

À caça de enredos que vêm convertendo experiências difusas da vida em objetos passíveis de conhecimento e intervenção pedagógica, a presente pesquisa logrou a armação de um diagrama, não obstante estar ciente das reduções que se fizeram necessárias para que um vasto volume empírico assim se condensasse. Sua pretensão, afinal, não foi evidenciar verdades inequívocas, tampouco assimilar uma totalidade inteira sob seu bojo, mas tão somente apresentar um arranjo possível dos trânsitos discursivos identificados. Se há nisso algum ensejo representacional, que ele esteja apenas na redução necessária à montagem do diagrama. 
Assumidos tais limites, resta o risco de tornar a análise inócua em sua exposição. Isso porque, da transposição de um diagrama - com as sobreposições, os desvios, as concomitâncias e os encadeamentos por ele ilustrados de modo tão sintético - à forma textual ora requerida, impõe-se o desafio de manter a coerência e a inteligibilidade garantidas pela precisão gráfica. Que a leitura, doravante, possa fluir nesse sentido, a imaginar vetores entrecruzando-se, sobrepondo-se e sucedendo-se uns aos outros em um quadro de deslocamentos.

\subsection{Da crise à afirmação}

Na região asiática de Ladakh, o advento de uma instituição dedicada à educação formal em moldes comuns às sociedades escolarizadas é algo relativamente recente. Como efeito, uma tradição milenar ali agoniza, à medida que seus anciãos vão sendo sucedidos por jovens formados conforme um novo paradigma.

Ao menos, é isso o que nos conta o documentário Escolarizando o mundo, em relação ao qual o subcapítulo 1.4 desta tese formulou uma conjectura: se a crítica apresentada pelo filme fosse capaz de despertar algum engajamento em seus espectadores perante a descaracterização geracional do povo ladakhiano, ele provavelmente se daria no sentido de um resgate das formas autênticas de transmissão de saberes naquela comunidade. Seria necessário, então, estudar o modo como, ao longo da história de Ladakh, configuraram-se suas relações educativas cotidianas; uma vez compreendidas, tais relações poderiam porventura se restabelecer, em detrimento de um modelo formal, institucional, globalizado, padronizado.

Embora aí se trate de um exercício de mera especulação, o efeito imaginado segue um roteiro hoje habitual em relação a comunidades nativas que ainda mantêm sua unidade - ou parte dela -, como os povos indígenas brasileiros. Há em curso, é evidente, um amplo movimento de formalização da educação de índios no país, o que, em um sentido ampliado, remonta à atuação dos jesuítas no início da colonização [BRUM; CUNHA, 1997; HOFMANN, 2004] e se oficializa na Constituição de 1988, que assegurou a tais comunidades o direito à educação escolar [LAROQUE; SILVA, 2013].

Entretanto, há também a tentativa de identificar e compreender traços educacionais supostos como espontâneos às próprias práticas indígenas, em geral sob a alegação de defesa 
e fomento daquelas culturas. Segundo os autores que se alinham a essa última vertente, haveria uma lógica colonialista na escolarização de tais povos nativos, e "um dos pilares que sustenta essa postura é a negação em aceitar que a especificidade destes povos consiste, justamente, em terem processos educacionais próprios que os fazem ser como são" [PAULA, 2013, p. 438].

É nesse sentido que, em suas brincadeiras, as crianças de uma tribo Mbyá-Guarani estariam em meio a práticas educativas geradoras de modos de ser indígena [JESUS, 2010]; de maneira análoga, as crianças Terena seriam orgulhosas da identidade aprendida via experiências cotidianas [BROSTOLIN; OLIVEIRA, 2013; ZOIA; PERIPOLLI, 2013]; os ritos da dança tomariam a forma de um aprendizado fundamental na formação do jovem Guarani [MENEZES, A., 2010]; as mulheres idosas Xavante portariam uma acentuada preocupação educacional a respeito da formação feminina das mais jovens [REZENDE; PASSOS, 2012]; ao passo que, entre os adultos e as crianças Xakriabá, haveria situações de aprendizado tanto difusas quanto mais estruturadas [SILVA, R., 2012]. Dotada de uma educabilidade intrínseca, portanto, a história dos povos indígenas estaria atravessada por práticas e processos educativos não formalizados, os quais configurariam matéria ao campo pedagógico. Trata-se, grosso modo, do que se convencionou denominar educação informal.

É evidente que a defesa do direito de tais comunidades nativas à educação formal é campo de lutas intrincado já há algum tempo. Porém, o que os exemplos acima expostos evidenciam, na mesma linha argumentativa do documentário sobre Ladakh, é a valorização atual de processos educativos espontâneos e inerentes àquelas tradições. Por meio dessa valorização, uma sequência em geral se evidencia: reconhece-se uma educação informal atuando e, então, produz-se um conhecimento acerca dela. Ao menos, é essa a direção em que tais asserções se apresentam, mas a ela poderíamos contrapor uma hipótese inversa: produzir-se-ia conhecimento acerca de supostas dimensões educativas de determinado contexto e, então, reconhecer-se-ia, ali, uma educação informal (a mesma recémconceituada) em operação. No mesmo movimento, portanto, seja ele assumido em uma ou em outra direção, amalgamam-se educabilidade e intencionalidade (esta reconhecida, e não a ser atribuída), ambas supostas como naturais e intrínsecas às práticas tradicionais desses povos.

De todo modo, não é de hoje que se reconhecem as dimensões educativas de comunidades não escolarizadas. Recentes talvez sejam sua valorização e sua apologia como direito a ser mantido, em tempos em que a instituição escolar deixou de ser alvo único e 
inconteste das preocupações educacionais. Vejamos como o assunto aparecia em um momento um pouco mais recuado no tempo.

Em texto datado de 1957, João Roberto Moreira [1957b, p. 53] admitia que a “educação informal, não elaborada, se realiza permanentemente em qualquer tipo de sociedade". Na ocasião, o sociólogo catarinense procurava discutir os contextos sociais que teriam demandado o surgimento da escola. Dizia ele que nas "comunidades mais primitivas basta comunicar o conhecimento necessário e fazer com que o grupo se mantenha unido, o que muitos julgam ser o objetivo básico de tôda a educação. Esta forma de educar é, porém, sujeita a certos defeitos" [MOREIRA, 1957b, p. 53]. Os defeitos referidos residiriam sobretudo no fato de não haver ali uma consciência propriamente educativa que justificasse o processo de transmissão e definisse seus caminhos mais adequados. Daí a seguinte asserção de Moreira [1957b, p. 54]: "Eis por que tais processos, tal forma de ação educativa só podem ser justificados de um ponto de vista empírico-prático. Cumprirão seus fins, mas ninguém saberá bem por que, à falta de justificação teórica ou de razões".

Em vez de valorização, o autor explicita o que, sob o olhar contemporâneo, formulase em um evidente etnocentrismo, afirmando a existência de uma instituição formal e escolar como índice de complexidade e desenvolvimento de uma sociedade.

Desde que as sociedades humanas atingiram a um estágio de desenvolvimento em que êstes fatos foram compreendidos, a escola tornouse uma necessidade social. Neste sentido, podemos dizer que a educação formal, organizada e dirigida, das civilizações bem desenvolvidas, é nada mais, nada menos do que a tentativa de vencer êsses defeitos graves das rotinas sociais e do comportamento, adquiridas por simples imitação, simples repetição do já feito. [MOREIRA, 1957b, p. 55]

Assim, tendo em vista demonstrar como se pode vencer as graves falhas a que faz alusão, Moreira [1957b, p. 55] esboça nos seguintes termos o modo de operação de um plano de escolarização em uma sociedade:

O que se pretende realizar através dêle [do plano de escolarização] é a orientação geral de tôda a educação em tôdas as suas formas e modalidades, mesmo no que ela tem de espontâneo, de não orientado, de não dirigido, de não intencional. Isto porque, se, através da escola, das formas institucionais 
de educação, conseguimos criar nos indivíduos e nos grupos humanos em geral a atitude e o hábito de agir em função de razões bem fundamentadas experimental ou factualmente, estaremos reduzindo de muito os inconvenientes da simples e cega imitação que leva àquelas rotinas que temos caracterizado em seus defeitos e perigos.

Se o autor reconhecia que a educação se efetua de modo difuso em qualquer grupo social, desde os mais primitivos, ele também estava convicto em sua afirmação de que a escola representaria, entre as possibilidades educacionais, a forma mais avançada, bem acabada e à prova de distorções. Em outros termos, seria ela "um dos meios mais importantes, senão o principal, de a educação se realizar" [MOREIRA, 1957a, p. 99]. A centralidade da escola - em uma sociedade desenvolvida ou que almeja evolução, claro está seria para ele inquestionável, de modo que sua crítica volta-se integralmente às espontaneidades educativas, quando à revelia de uma direção formal e intencionada. Trata-se de uma perspectiva bastante distinta da recente valorização que há pouco vislumbramos acerca das possibilidades educativo-culturais dos povos indígenas. Ambos os posicionamentos, porém, têm em comum a pressuposição de uma educabilidade, tendo seu ponto de partida em um mesmo quadro do diagrama.

A visão de Moreira é corroborada por diversos autores que lhe foram contemporâneos naqueles meados do século XX, embora em termos mais sutis. Para Anísio Teixeira [1953a, p. 20], por exemplo, a "escola, propriamente dita, sòmente aparece em estágio avançado e complexo da cultura, quando esta, já consciente, adquire as técnicas intelectuais da leitura e da escrita e o saber pelo livro, cuja transmissão não se pode efetuar senão sistemàticamente". Aí também, como se vê, a instituição escolar comparece como índice de desenvolvimento, o que em parte justifica a centralidade que ela adquiria no interior de um discurso comprometido com o progresso então considerado necessário ao país.

Tendo por horizonte os padrões civilizatórios delineados pela Modernidade, tais intelectuais formulavam o desenvolvimento nacional como problema ao pensamento, cuja solução repetidas vezes fixou-se na instituição escolar. Nesse sentido, identificada como centro e forma dominante de educação, a escola foi resposta direta e convicta a demandas variadas que decorriam daquele problema principal, sobretudo nas décadas de 1940 e 1950. Decerto já o era antes, mas cumpre-nos aqui manter em atenção o período e o suporte em pauta. 
Com efeito, Anísio Teixeira marcou sua participação nos primeiros anos de existência da $R B E P$ a afirmar a relevância da instituição escolar perante as transformações que o Brasil atravessava. O intelectual baiano, como é evidente, não negava um sentido ampliado à educação - por ele "compreendida como o processo de transmissão da cultura, ela se opera pela vida mesma das populações" [TEIXEIRA, 1953b, p. 3] -, mas via na escola a resposta direta à crise e o instrumento mais adequado de difusão de uma consciência nacional. Seu argumento entretanto, não se resumia a tal afirmação, mas estendia-se à necessidade de uma verdadeira reconstrução educacional. Afinal, Teixeira estava entre os principais signatários do Manifesto dos Pioneiros da Educação Nova, que ao menos desde 1932 propunham novas bases à educação escolar efetivada no país.

Ainda que suas proposições demonstrassem insatisfação, tais reformadores apenas podiam projetar uma reforma da instituição escolar, com tamanha convicção, por estarem alinhados com a assunção de uma centralidade daquela instituição. O próprio Manifesto evidenciava uma preocupação àquela época centrada quase exclusivamente na instituição escolar: "a educação que, no final de contas, se resume logicamente numa reforma social, não póde, ao menos em grande proporção, realizar-se senão pela acção extensa e intensiva da escola sobre o indivíduo" [RBEP, 1984, p. 410]. Se a escola era peça central na educação de um povo, ela deveria se adequar para fazer frente à crise que se atravessava. Era preciso reformar a instituição escolar, reconstruí-la.

Figura de destaque naquele contexto, Fernando de Azevedo [1957] era mais um a reconhecer a efetividade de espaços educativos dispersos no meio social, mas não os tomava como adversários da escola na tarefa educativa. Em sua concepção, as escolas seriam um feixe necessário de educação organizada e sistematizada em meio a esse campo tão vasto de possibilidades difusas. Em suas palavras:

\begin{abstract}
A rua, as conversas, os espetáculos, as relações, o ar do tempo, as modas que se sucedem (mesmo as modas da linguagem) atuam constantemente e poderosamente sôbre seu espírito [do indivíduo]. Mas, essa observação, de todo ponto exata, não amesquinha, nem reduz o papel da escola na vida social. [AZEVEDO, 1957, p. 61]
\end{abstract}

Já aí não há a convicção explícita de defeitos e perigos relativamente aos processos educativos espontâneos, tal como alegava Moreira [1957b]. Para Fernando de Azevedo, não se tratava propriamente de repelir traços primitivos, mas de reafirmar uma predominância institucional. Nesse sentido, reconhecia-se uma educação difusa efetuando-se nas práticas e 
relações cotidianas; concebia-se, até mesmo, a importância de que a educação "se realize concretamente, dentro da vida" [LEÃO, 1944, p. 175]. Todavia, uma ressalva comum vinha sempre a reboque de tais admissões: "a vida, em tôdas as suas manifestações, deverá refletirse na escola" [LOURENÇO FILHO, 1944b, p. 222].

Lourenço Filho, personagem assíduo nas páginas da RBEP, também estava entre os autores que se dispunham a exaltar a centralidade da escola. Suas premissas encontravam forma para além da justificativa etnocêntrica, evolucionista. O então diretor do Inep assim apresentava uma das razões, a seu ver, para tal absorção majoritária da tarefa educacional pela instituição escolar naqueles tempos: mediante "o enfraquecimento da ação educativa de outras instituições sociais (a família, a igreja, o grupo profissional), a escola passou a ser, dos fins do século passado para cá, um órgão capaz de funções mais completas” [LOURENÇO FILHO, 1944b, p. 222]. ${ }^{33}$

Para além das reflexões internas ao campo educacional, argumento semelhante faziase presente, ainda, entre figuras diretamente envolvidas no contexto político nacional. É o caso de Eurico Gaspar Dutra, que, por ocasião de sua candidatura à presidência, discorreu sobre a necessidade de se considerar uma dimensão educacional estendida na "existência de cada homem", reiterando, porém, o monopólio escolar: "Para se dar maior alcance aos meios de educação extra-escolar, não deve ser esquecido que a influência mais profunda e duradoura da educação advém da ação da escola, e que se realiza, assim ao contacto dos mestres" [GASPAR DUTRA, 1946, p. 15].

Nas mensagens oficiais redigidas por ministros e outras figuras ligadas à administração pública, tal preocupação também era peça constante. Em 1955, Cândido Motta Filho, por exemplo, encontrava na escola a resposta política à "tormentosa experiência de um mundo em mudança", sobretudo como forma de garantir a liberdade: "pode a escola reencontrar-se a realizar aquilo que dela mais necessitamos: a conceituação do homem como existência livre, dentro de uma coexistência propícia à liberdade" [MOTTA FILHO, 1955, p. 9].

O ponto que ser quer afirmar aqui não é o reconhecimento, ou não, de uma educação efetivada para além da escola. Guardadas as especificidades de cada caso, a todos esses

\footnotetext{
${ }^{33}$ Em tal argumento de Lourenço Filho, configura-se cenário inverso ao que hoje se alega como razão ao espraiamento educacional para além da escola: se lá outras instituições veriam enfraquecida sua ação educativa, atualmente se alega um enfraquecimento por parte da própria escola, em detrimento da fortalecimento de funções educadoras por outras instâncias (tais como a família, a igreja e o universo profissional, as mesmas aludidas por Lourenço Filho, entre outras).
} 
autores parecia estar evidente que a educação "tem campo infinitamente mais amplo do que o da escola"; que a "educação em geral se faz pela família, pela igreja, pela rua, pelo clube, pelo trabalho, pela vida, enfim" [TEIXEIRA, 1959, p. 297]. O próprio documento constitucional de 1946 firmaria a distinção entre dois campos educativos - um genérico e um especializado: "Quando se examina a Constituição, verifica-se que seu texto distingue entre educação, ação formativa genérica dada no lar e na escola, e ensino, de que legislação própria deverá cuidar" [LOURENÇO FILHO, 1961, p. 54]. Embora os exemplos tenham se estendido na afirmação de algo supostamente óbvio, entretanto, a repetição aqui se faz deliberada, já que é no campo dos consensos que nos movemos.

E uma vez reconhecido o consenso a respeito dessa educação geral, a afirmação e a defesa da instituição escolar como locus educativo por excelência não é inconteste, mas datada. Trata-se de um caminho delimitado - entre os possíveis - do espontâneo ao intencional. O reconhecimento de uma educação para além da escola não se transtorna, aí, em solução a nada (seja a uma crise, seja a uma crítica, seja a uma demanda), mas aparece tão somente como constatação. A solução situa-se, em todos esses casos, no interior institucional, e nunca em seu exterior. Como pano de fundo, a defesa convicta de um aparelhamento escolar, tal como mais uma vez sintetizaria Anísio Teixeira [1964, p. 212] em observação retrospectiva: "O nôvo tipo de sociedade - democrática e científica - não podia considerar a sua perpetuação possível sem um aparelhamento escolar todo especial. Os velhos processos espontâneos da educação já não eram possíveis".

Se lá já não eram possíveis, no entanto, os velhos processos espontâneos conquistam espaço significativo em parte do discurso pedagógico contemporâneo. É o que observamos a respeito da valorização recente da experiência educativa tradicional perante o que se passa em Ladakh ou nas comunidades indígenas. Assim, uma contraposição se torna evidente. De todo modo, mesmo quando há tal valorização, há também uma intencionalidade sendo atribuída: supõe-se reconhecer processos já existentes, supõe-se produzir um conhecimento sobre eles, supõe-se compreender as intencionalidades em jogo. Apesar da narrativa apassivada, no entanto, trata-se aí de uma operação ativa e intervencionista em seus efeitos, ao menos na proposição de um cenário a ser resgatado ou intensificado. O caminho que vai da suposição de um espontâneo educativo à assunção/atribuição de uma intencionalidade necessária é via obrigatória aos vetores traçados. Entre um polo e outro, o (re)conhecimento da educabilidade, sua inserção no campo de um saber possível, nos jogos veridictivos. A 
partir de práticas sociais difusas, forja-se um domínio de saber e, consequentemente, de intervenção.

Até aqui, dois paraísos se forjam. De um lado, na forma de uma intencionalidade institucional, artificial, socialmente estabelecida conforme a rota evolutiva trilhada por um povo. Um paraíso civilizado, escolarizado, apartado de seu primitivismo nativo. Um paraíso regido pela centralidade da escola - de preferência, uma escola reformada.

De outro lado, a partir de uma intencionalidade natural, tradicional, secular, a ser resgatada, fomentada, valorizada, delineia-se um paraíso supostamente mais afeito a um desenho originário.

\subsection{Da crise à expansão}

Pouco mais de seis décadas após a divulgação do Manifesto dos Pioneiros da Educação Nova, seu texto foi integralmente republicado na edição comemorativa de 40 anos da RBEP. Descolado de seu contexto original, o documento evidenciava um desajuste perante as novas conjunturas.

Naquele mesmo fascículo da revista, Paschoal Lemme [1984] afirmava que a reconstrução educacional proposta pelos reformadores dependia de uma democratização efetiva da sociedade brasileira, cujo desenvolvimento econômico ter-se-ia destorcido. De tal distorção, segundo o autor, "decorrem forçosamente as frustrações e as desilusões dos educadores que, em sua boa fé, insistem em imaginar que a educação e o ensino escolares são os fatores fundamentais para modificar essa situação" [LEMME, 1984, p. 271]. Em tempos em que a crença na reforma educacional já não se sustentava, a solução depositava-se na reforma do próprio tecido social, via democratização - ou redemocratização, para usar um termo caro àquele ano de 1984.

Como vimos, uma concepção educacional alargada já aparecia pressuposta nas asserções convictas da predominância institucional, mas não era majoritariamente assumida como locus de respostas possíveis aos problemas sociais. Ao longo dos 62 anos que separam a primeira divulgação do Manifesto e tal republicação, diversos acontecimentos se operaram para que a aposta na reconstrução educacional - e na centralidade escolar, por conseguinte não mais soasse suficiente. 
Embora os intelectuais brasileiros já referissem um conceito educacional ampliado, que ultrapassava os limites escolares (ainda que nele se centralizasse), é de autoria norteamericana uma das primeiras menções veiculadas pela $R B E P$ que explicitamente formula a proposição de uma educação para além da escola, com suas respectivas especificidades. Edward G. Oesen, em texto originalmente publicado em 1949 e traduzido para os leitores brasileiros em 1954, assim apresentava a questão:

Os programas modernos de educação organizam-se tendo como ideia essencial e básica que a criança é um ser complexo e como tal deve ser educada dentro como fora da escola, aproveitando para isso tôdas as oportunidades que se apresentarem. Daí se deduz que escola e educação não são, evidentemente, sinônimos. [...] Nada melhor que a experiência da vida para educar o indivíduo em qualquer uma das múltiplas atividades a que êle se dedique. [OESEN, 1954, p. 27]

Estabelecia-se, então, não mais uma relação de contiguidade entre o que se passava na escola e em seu exterior, mas de contraposição. Se até então eram frequentes os argumentos que, alegando reconhecer dimensões educativas bem mais amplas do que pode proporcionar a escola, concluíam-se apontando a prerrogativa de tal instituição na formação dos cidadãos, o autor estadunidense agora advogava em favor de uma potência educativa e formadora externa à oferta escolar. Na sequência, ele listava uma variedade de meios alternativos à instituição formal:

Os cinemas e igrejas, bares e salões para jogos de boliche, revistas cômicas e automóveis, YMCA'S [Associação Cristã de Moços], salões de jogos diversos, rádio, jornais, além da escola, são inegàvelmente órgãos educativos. Pois, cada um, devido à sua participação intensa e diária na vida de todos os indivíduos, fornece campo propício à aquisição de valores e normas, idéias e aspectos, atitudes e objetivos tão necessários à vida. [OESEN, 1954, p. 27]

A partir de seus argumentos, Oesen [1954], entretanto, não excluía a validade da educação escolar. A escola, segundo ele, deveria ser articuladora daqueles variados recursos, assumindo o papel de coordenar os serviços educacionais que se efetivavam em outros espaços. Daí porque o autor concebia uma intensa cooperação entre escola e comunidade, convocando o advento de uma escola de comunidade.

Esta escola de comunidade concebe a educação como uma grande responsabilidade que não pode estar sòmente restrita à escola. Considera que a escola tem uma obrigação básica que é dirigir e conduzir a 
comunidade em tôdas as atividades, em cooperação, bem como apreciar e julgar a política e o programa escolares. [OESEN, 1954, p. 37]

Na mesma direção se desenvolveu o único texto ${ }^{34}$ de Paulo Freire que estampou as páginas da RBEP. Em 1961, o educador pernambucano marcava sua participação na revista discorrendo sobre o estatuto da educação primária em um momento brasileiro - para variar considerado de transformação. A despeito do tema circunscrito, no entanto, Freire [1961, p. 28] defendia uma integração entre a escola e seu entorno, e é válido observar como se desenrola seu argumento:

Há todo um esforço do povo espalhado em sociedades beneficentes, em clubes recreativos, em sindicatos, em associações religiosas, nos centros urbanos ou, em menor escala, nas comunidades rurais brasileiras, que poderia ser aglutinado e sistematizado pelo Poder Público [...] O que há de se fazer no Brasil, sobretudo em áreas mais fortemente subdesenvolvidas, é aproveitar esse esforço do povo e ajudá-lo em suas respostas. Ao invés de continuarmos a "plantar" escolas ou unidades pedagógicas sem vinculações sistemáticas e estreitas entre si e com sua localidade, deveríamos tentar experiências de integração da escola em sua comunidade local.

A integração por ele proposta em muito se aproxima da escola de comunidade conceituada por Oesen [1954]. Em ambos os casos, a instituição escolar deveria ter, entre suas missões primeiras, a abertura a uma íntima cooperação com seu exterior. Assim, se a escola absorvia parte significativa do intento educacional, não se deveria ignorar as dimensões educativas existentes para além dela. Ao menos, era preciso dispensar atenção equivalente aos dois âmbitos.

Tal foi também o eixo argumentativo seguido por Primo Nunes de Andrade em 1958, em mais uma das reflexões sobre a crise que assolava o contexto nacional. Como ponto de partida, o autor demonstrava considerar uma educação moral difusa, realizada "através da família, dos círculos restritos de convivência social, das comunidades religiosas, das escolas, dos sistemas públicos, de difusão de conceitos e costumes, tais como o rádio, o cinema, a televisão, a imprensa" [ANDRADE, 1958, p. 47]. Na sequência, Andrade [1958, p. 67] afirmava que, se o ensino formal demandava reforma, o mesmo deveria valer aos demais meios e espaços: "A educação, no seu conceito mais amplo, abrange não só o sistema educacional de caráter intelectual e prático, que deve adaptar-se à nova cultura, mas também o próprio processo natural e espontâneo de propagação desta". Antes constatadas como

\footnotetext{
${ }^{34}$ Republicado em 2005, na edição comemorativa de 60 anos da RBEP.
} 
realidades inevitáveis, as possibilidades educativas das práticas sociais ingressavam, então, no foco de determinado olhar pedagógico.

O vetor discursivo que anuncia a expansão educacional para além da instituição escolar inicia-se, como se vê, em concomitância à premissa de uma centralidade da escola. É provável que tal centralidade não se tenha diluído ainda nos dias de hoje. Fato é, entretanto, que ela parece ter deixado de ser resposta pedagógica única a problemas variados; no mínimo, passaria a conviver com a admissão de outras soluções.

Se no subcapítulo anterior deparávamos dois enredos possíveis a partir da educabilidade espontânea de um povo - um deles rumo a uma intencionalidade institucional, o outro na direção de uma intencionalidade originária a ser reconhecida -, agora estaríamos diante de um movimento englobante desses dois caminhos: uma intencionalidade vigorosa e robusta começaria a investir um espectro mais alargado de atuação.

1967 foi um ano-chave às discussões educacionais não apenas na $R B E P$, não apenas no Brasil. Foi o ano em que ocorreu a Conferência Internacional sobre a Crise Mundial da Educação, que consolidaria tanto a urgência de uma reforma integral do ensino formal, quanto a insuficiência de tal reforma se não articulada a uma ampliação da atuação educativa para fora da escola. Se isso já vinha sendo sugerido, vez ou outra, agora adquiria estatuto de diretriz internacional. A efetividade da reforma escolar, por si só, estava definitivamente descreditada.

Phillip Coombs, autor do relatório oficial daquele evento, em forma de livro - A crise mundial da educação -, ocupou algumas páginas da revista em 1969, reforçando a existência de uma crise causada, sobretudo, pela intensa expansão demográfica e apontando, entre outras implicações, que

[...] o planejamento educacional precisa voltar sua atenção não sòmente para o sistema educacional formal, mas considerar também o grande número de atividades de treinamento de caráter educativo e informal, e potencialidades, extremamente importantes para o desenvolvimento individual e nacional, que podem frequentemente obter resultados que a formal não alcança. [COOMBS, 1969, p. 430] 
Em 1968, já na edição seguinte àquela que publicou documentação referente à Conferência, a RBEP trazia em suas páginas as mostras de que, a partir de então, a educação nacional passaria a ser pensada com base nas diretrizes estabelecidas pela UNESCO e aludidas no livro do autor norte-americano. É o que se evidencia na transcrição da aula inaugural ministrada por José Vieira de Vasconcelos [1968, p. 55] na Universidade Federal da Bahia:

[...] o sistema escolar entre nós permaneceu ligado a estruturas da época pré-industrial, enquanto outros setores da vida produtiva, econômica e social foram profundamente afetados. O sistema ignora os novos tipos de estímulo cognoscitivo; a esta inovação nas fontes e acumulação intelectual, o ensino formal opõe em geral a rigidez de processos obsoletos e quase sempre ligados a um sistema de sanções jurídicas como motivação principal.

A obsolescência do ensino formal era descrita pelo acadêmico por meio da identificação de diversos focos de inércia do sistema escolar. Na sequência, a afirmação categórica: "a educação não é só escola; um dos nossos problemas neste campo é justamente estudar o aproveitamento dos outros recursos educativos, tão utilizados em países com escolas mais numerosas e melhores do que as nossas" [VASCONCELOS, 1968, p. 56]. Se outrora a constatação de que a educação não se resume à escola dava lugar ao fortalecimento do monopólio escolar em relação às funções educacionais, doravante se projetava a necessidade de estudar outros recursos educativos, menos obsoletos.

Tal inversão tornar-se-ia evidente na própria RBEP nos anos seguintes, à medida que a preocupação com a instituição escolar passava a conviver com o investimento discursivo em alternativas a ela - fossem suas complementares, fossem suas substitutas. $\mathrm{O}$ autor francês Archer Deléon [1969, p. 26] compreendia o momento em termos de uma enorme revolução educacional:

Já não se trata de pequenas reformas e melhorias fragmentadas, de educação popular nem de educação de adultos, nem de atividades culturais, nem de promoção cultural e social, nem mesmo de educação permanente no velho sentido do têrmo. [...] Não se trata, nem de um campo particular, nem de um conteúdo particular; falando de educação, nós falamos atualmente de tudo.

As palavras de Durmeval Trigueiro [1969, p. 12] são também bastante ilustrativas do que vinha a ser aquela revolução: 
Cessa o tempo escolar - há um tempo contínuo; cessa o espaço social escolar - há um espaço social contínuo; cessa a exclusividade da técnica escolar - quase tôdas as técnicas sociais podem transformar-se em técnicas de educação. Todos os tempos são tempos da educação; todos os lugares são lugares para a educação; tôdas as formas de comunicação e contrôle social podem reduzir-se ao processo educacional.

Alguns anos mais tarde, tal enunciado já se formulava de forma ainda mais estabelecida, não mais como novidade ao campo pedagógico:

Será possível atender à demanda de mais oportunidades de educação apenas através da educação escolar? De uma educação que é adquirida em determinada fase da vida? A nosso ver, a saída a ser apresentada está na educação como um sistema aberto que utilize todas as potencialidades da sociedade para formar e criar valores. Educação como tarefa do dia-a-dia e de sempre; como responsabilidade de cada um e de todos. [...] A Educação passa a ser uma tarefa que o homem há de realizar, contínua e constantemente, em todas as situações que está vivendo. [FÁVERO, 1974, p. 32]

Haviam-se expandido definitivamente os tempos, os espaços e as técnicas de educação. No mesmo golpe, expandira-se também a responsabilidade pela tarefa educativa.

$* * *$

Em 1965, ano imediatamente pós-Golpe de 1964, o então presidente Humberto Castelo Branco [1965a, p. 71] anunciava a "lamentável situação" de analfabetismo encontrada pelo novo regime, declarando que "o ano de 1965 deverá ser marcado pela proficuidade dos trabalhos destinados a assegurar um aperfeiçoamento decisivo de nossa vida educacional".

A alegação de um estado crítico na conjuntura antecedente do país, conforme se sabe, operava uma importante maquinaria de propaganda do novo regime. Nas várias mensagens governamentais que circularam naqueles anos, recorrentemente se afirmavam mazelas nacionais acarretadas por variadas crises, por um analfabetismo disseminado, por um sistema de ensino inoperante. Como resposta, era preciso traçar um plano a curto prazo, cujos resultados já se efetivassem no presente: “a Nação adquirira a consciência de que a educação constituía um dos focos em que mais urgente se tornara uma presença saneadora" [CASTELO BRANCO, 1965b, p. 166]. Tal urgência, por diversas vezes, coincidiu com a 
preocupação voltada a uma ampliação etária da tarefa educacional. Os anseios governamentais mostravam-se então atentos sobretudo à formação dos adultos, peças mais imediatas à configuração social e política que se intencionava estabelecer.

Lourenço Filho foi figura de destaque na defesa de uma ampliação etária ao intento educacional. Se em diversos momentos seus textos embasam-se na centralidade escolar, quando se punha a pensar a educação de adultos, porém, ele afirmava certa insuficiência de um modelo escolar demasiado centrado na educação infantil. Em suas palavras, "o processo escolar não tem bastado como recurso normal de educação intencional. A necessidade de educação ou de reeducação está assim presente em todas as idades" [LOURENÇO FILHO, 1945, p. 170].

No tocante às urgências daquele tempo, o intelectual não titubeava em assumir que, a seu ver, a prioridade do sistema educacional deveria estar na educação de adultos. O que não equivalia a abandonar os mais novos, como ele fazia questão de reiterar: "por amor às crianças, é que devemos educar os adultos" [LOURENÇO FILHO, 1947, p. 14]. Tratava-se de acolher demandas urgentes (em face de uma recorrente crise, de uma expansão demográfica, de um analfabetismo preocupante), e para isso dever-se-ia depositar foco na educação do povo - este capaz de empreender transformações sociais efetivas -, âmbito no qual as crianças não estavam incluídas.

Na mesma direção, outros autores dedicaram-se, à época, a delimitar um quadro argumentativo que estabelecesse a idade adulta entre os desígnios educacionais. É evidente que a educação de adultos não tinha ali seu ponto preciso de emergência. Entretanto, não parecia ser tema amplamente difundido, já que era quase sempre prevendo alguma resistência que tais enunciados se apresentavam.

Luís Reissig [1952a, p. 80], por exemplo, antecipava a indagação que lhe poderia ser endereçada: "Mas, não são a infância, a adolescência e a juventude as idades apropriadas para educar-se, saber, empreender, realizar, conquistar, criar em definitivo a cultura, a civilização, a sociedade e o mundo?” E ele próprio já ofertava a resposta, asseverando que "todo indivíduo, em qualquer idade e condição, pode adquirir novos conhecimentos, técnicas, hábitos, costumes; numa palavra: educar-se e reeducar-se. A idade da educação não desaparece para ninguém enquanto viva” [REISSIG, 1952a, p. 80].

A julgar pelos textos que alguns anos mais tarde ganhariam maior espaço na revista, a estratégia de afirmação da educação de adultos como campo prioritário obteve significativo 
êxito - já então sob a alcunha de uma educação permanente. "Para um mundo em contínua mudança, só uma Educação Permanente criaria condições de modo que o homem pudesse atuar lúcido como agente e ao mesmo tempo como beneficiário do grande esfôrço social" [RBEP, 1969, p. 6].

Tendo em vista que um dos principais problemas a que a educação de adultos oferecia saída era o analfabetismo, torna-se fácil supor que sua efetivação se dava mormente em uma forma escolarizada. No entanto, concomitantemente, ela era também resposta a uma insuficiência escolar (responsabilizada de imediato pelo analfabetismo), de modo que sua formalização na maioria das vezes não se dava nos estabelecimentos de ensino convencionais. Era preciso, em alguma medida, que aqueles adultos se educassem fora da escola.

Escolarizar todo mundo segundo o modelo tradicional ultrapassa de muito a soma de recursos materiais e humanos com que conta a maioria dos países, e especialmente os que ainda estão em processo de desenvolvimento. A única saída que, no momento, se poderia vislumbrar, parece estar na educação permanente, ligada não só à atividade profissional, mas a toda a práxis humana: cívica, social, cultural, política. [TRIGUEIRO, 1969, p. 15]

A necessidade de educar adultos trazia consigo, portanto, a abertura a uma educação permanente, a imbuir de função formativa âmbitos profissionais, cívicos, sociais, culturais e políticos. Se era preciso educá-los e se não se dispunha de uma escola suficientemente abrangente, fazia-se necessário investir outros contextos, dissolvendo fronteiras existentes. Já em 1974, seria possível ao mesmo autor afirmar que a "educação da criança, do adolescente e do adulto situa-se dentro do mesmo tempo e do mesmo espaço social. Isto é o mesmo que dizer que se torna cada vez mais irrelevante a fronteira entre a escola e a sociedade" [TRIGUEIRO, 1974, p. 167].

Quando a escola deixa de oferecer solução de totalidade aos problemas de um tempo (sobretudo devido à alegada expansão populacional), assim, recorre-se ao seu exterior. Seja ele etário, espacial, temporal. Estava dado o ensejo a uma alunização (a reboque de uma infantilização) de jovens, de adultos e, posteriormente, de idosos. O desenvolvimento humano passava a ser concebido ao longo de toda a vida. Por extensão, ampliava-se também o próprio mercado educacional, produzindo mais demanda por profissionais em formação tanto aqueles do próprio domínio pedagógico, quanto aqueles de outras especialidades, já então investidas de uma função educadora. 
Se a dimensão etária foi o alvo mais evidente de uma expansão educacional naqueles meados do século XX, outros movimentos nesse sentido, embora menos recorrentes, também se notavam rumo a práticas e espaços variados.

Já na década de 1940, por exemplo, é possível encontrar a defesa, inspirada em um caso mexicano, de que se empreendessem missões culturais (ou educativas) no Brasil a fim de civilizar os povos ainda não urbanos, inserindo-os nos padrões de conduta desejáveis à identidade nacional.

Seria assim uma espécie de busca à realidade do sertão, num autêntico extravasamento de assistência do homem civilizado ao homem rude. Para um país como o nosso, de tênue densidade, não há solução mais econômica - pois a missão é formada por pessoal escolhido entre funcionários do Estado - nem mais satisfatória, que possa vir galvanizar as energias indômitas do nosso caboclo, cuja vida continua amordaçada por uma das mais dolorosas misérias porventura atuantes em um povo. [RBEP, 1945b, p. 521]

Se tal consideração denunciava uma ausência de empenho governamental relativamente à educação dos povos rurais, em 1957 Gilberto Freyre já demonstrava maior clareza a esse respeito, em fala proferida a professores rurais em treinamento. Alegando que os problemas rurais e urbanos deveriam ser tomados em conjunto, e não em oposição, o autor convocava o desenvolvimento do que ele denominava uma mentalidade rurbana. Para tanto, recorria fundamentalmente à educação: "Para a formação dessa mentalidade ou dêsse espírito conjugal rurbano [...], quem mais capaz de concorrer que a professôra, a mestra primária, a educadora cujo ensino ou influência alcance não só a gente miúda como a grande ou adulta?" [FREYRE, 1957, p. 66]. Segundo Freyre [1957, p. 67], ainda, o sistema brasileiro estaria organizado de um modo pan-urbano, dedicado

[...] a arrancar a criança rural do meio rural, a raptar o adolescente rural do campo ou da aldeia materna, a atrair o homem rural para a cidade anti-rural. Como não existir esse desenraizamento sistemático do homem rural desenraizamento pela educação, às vezes pelo próprio cinema ironicamente chamado educativo, pelo rádio - se todo nessa educação, nesse rádio, nesse cinema educativo, é glorificação de valores urbanos e só urbanos? 
Alguns anos depois, um texto editorial de 1962 apresentava breves quadros da política educacional do país e se encerrava afirmando que, além da educação proporcionada pelos estabelecimentos de ensino formal, era preciso levar em conta o processo educativo desenvolvido "junto às populações rurais, através do trabalho de extensão, que orienta e dá assistência ao agricultor e à sua família, objetivando a racionalização dos empreendimentos agrícolas e a melhoria de hábitos alimentares e de higiene" [RBEP, 1962, p. 4]. Aos poucos, a educação do homem do campo parecia ocupar algum espaço nas preocupações políticopedagógicas.

Outro eixo raro no conjunto textual da $R B E P$ é o que concerne às questões ambientais, que tardou a adquirir vulto nas publicações da revista. No início da década de 1950, ela comparece pontualmente como alvo de preocupação geral, mas ainda não propriamente vinculada à educação. "Um dos grandes problemas do mundo é o de assegurar a conservação e o desenvolvimento de seus recursos naturais. É tanto obra técnica e científica como também de educação. Há terras dilapidadas pela ignorância” [REISSIG, 1952a, p. 83].

Foi na década de 1970 que a preocupação ambiental passou a se tornar mote frequente de lutas internacionais, sobretudo após a realização, em 1972, da Conferência das Nações Unidas Sobre Meio Ambiente Humana, também conhecida como Conferência de Estocolmo. Como efeito, já em 1973 o assunto reverberaria na revista do Inep, em documentação que trazia as recomendações traçadas a partir da $3^{a}$ Conferência Internacional sobre Educação de Adultos. Uma das premissas apresentadas na ocasião era a "utilização abusiva e a contaminação do meio ambiente, que põem em perigo a existência do homem" [RBEP, 1973a, p. 547].

Ainda, em sua tipologia tripartida de educação extra-escolar, Pierre Furter [1973, p. 418], naquele mesmo fascículo, já incorporava uma categoria denominada domínio do ambiente, brevemente descrita como um eixo então recente que, segundo ele, deveria tornarse "cada vez mais importante, à medida que a preocupação pela ecologia aumente em nossas sociedades". O autor tinha razão em sua previsão, uma vez que, conforme os levantamentos deste trabalho, o tema se tornaria dos mais recorrentes nas últimas duas décadas.

Daí um paraíso - agora sim -, já plenamente educável, no qual a escola passaria a conviver em complementaridade com uma multiplicidade de ocasiões educativas. Um paraíso, ainda, esquadrinhado em dimensões espaciais e temporais não mais dispostas em um único plano. 


\subsection{Da crise à recusa}

De 1944 e 1967, a escola foi instituição tomada como certa e inquestionada nas páginas da $R B E P$. Era resposta inequívoca a problemas variados. Quando julgada obsoleta, deveria reformar-se; quando considerada insuficiente, deveria expandir-se, complementando seu alcance via outros meios. Não lhe era direcionada qualquer crítica que a deslegitimasse por inteiro, senão à sua configuração em determinados contextos. Foi apenas perante a crise mundial alegada a partir da Conferência de 1967 que alguma recusa à instituição escolar começou a se formular.

Se a afirmação da centralidade da escola, da necessidade de sua reestruturação e da urgência de sua expansão conviveram em concomitância ao longo de vários anos, a recusa radical da instituição escolar não se afirmaria na $R B E P$ antes de 1974, sob a forma da desescolarização illichiana.

Embasada fundamentalmente na defesa de uma liberdade de aprendizagem, a resposta ofertada por Ivan Illich [1974, p. 188] concebia um sistema educativo (não escolar) voltado a três finalidades:

[...] permitir o acesso aos recursos disponíveis em qualquer época da sua vida, a todos aqueles que desejam aprender; dar a todos aqueles que desejam partilhar o que sabem a possibilidade de encontrar os que desejam aprender; conceder a todos aqueles que desejam submeter um problema ao público, os meios fazê-lo.

Tratar-se-ia de uma educação produzida, portanto, no rastro de desejos: aos que desejam aprender, oferecer-se-ia a disponibilidade de acesso; aos que desejam ensinar, a disponibilidade de aprendizes interessados. Nenhum dos dois estaria forçado "a submeter-se a um ciclo obrigatório" [ILLICH, 1974, p. 188]. A liberdade almejada, assim, seria contraponto à domesticação extrema ocasionada pela educação institucionalizada.

Uma outra revolução se anunciava:

A revolução educacional de Illich propõe-se a liberar o acesso aos objetos que possam proporcionar aprendizagem, garantir a liberdade de intercâmbio de habilidades, liberar o senso crítico e a criatividade das pessoas, oferecer aos indivíduos liberdade de escolher seus parceiros de estudo e de serem orientados pelo professor de sua escolha. [LIMA, 1974, p. 278] 
O desejo de aprender - ou de ensinar - já não é assunto inédito ao presente texto. Lembremo-nos de Beillerot (1985), para quem a pedagogização contemporânea tem um de seus lastros do desejo. Se trouxermos o argumento do autor francês ao encontro do pensamento illichiano, talvez forjemos um par complementar, tendo em vista a inusitada formulação que se insinua: ao que parece, a proposição projetada por Illich acabaria por desembocar no cenário descrito por Beillerot. Isso porque um mundo configurado a partir de desejos de aprender e de partilhar, não obstante suposto fora de uma maquinaria de obrigatoriedade e dominação, acabaria por se esquadrinhar integralmente em relações educativas, à moda da pedagogização analisada por Beillerot.

Daí que, talvez, longe de ser proposta inatingível, como por vezes hoje se alega, a desescolarização proposta por Illich e seus colegas, encontrava-se afinada com as tendências críticas daquele tempo. Àquela mesma época, havia quem reconhecia tal afinidade: "Muitos poderiam dizer que a teoria dos 'desescolarizadores' já ultrapassou o razoável e que, de qualquer modo, não tem nenhuma alternativa prática a oferecer; é verdade, porém, que a evidência empírica traz conclusões bastante próximas às dos 'desescolarizadores"” [RICHMOND, 1974, p. 252].

Ainda hoje talvez se possa dizer o mesmo, vide as já mencionadas iniciativas contemporâneas de desescolarização, como o hackschooling (de Logan LaPlante) e o uncollege (de Dale Stephens). Assim como as ideias do autor austríaco, tais projetos inseremse em um movimento de defesa e exaltação da educação fora da escola, iniciado a partir de meados das décadas de 1960 e 1970 (NOGUERA-RAMÍREZ, 2014). Para além da alegada recusa à instituição escolar, ambos os exemplos guardam ao menos duas semelhanças significativas em relação ao que Illich propunha: investem uma educabilidade intensificada, socialmente espraiada; e recorrem à tecnologia como importante meio à efetivação de uma educação desescolarizada. Os recursos tecnológicos que exploram, porém, são desiguais, já que os anos que se interpõem entre Illich e os dois jovens foram tempo suficiente para que a tecnologia comunicacional operasse uma quase revolução. 
Noção central na obra de Ivan Illich, as redes (ou teias) de aprendizagem foram por ele definidas nos seguintes termos: "Utilizaremos a palavra 'rede' para designar os meios específicos a fim de permitir o acesso a cada um dos recursos. [...] necessitamos de novas redes, facilmente acessíveis ao público e concebidas para oferecer iguais oportunidades de acesso à educação e ao ensino" [ILLICH, 1974, p. 189].

Tais redes, portanto, deveriam proporcionar o acesso a recursos variados àqueles que o desejassem. Estariam organizadas em quatro núcleos: serviços de consulta a objetos educacionais; serviços que promovessem o intercâmbio de habilidades; instituições que facilitassem o encontro de parceiros; serviços de consultas a educadores em geral. De que modo tal aparato se distingue das redes atuais dispostas as hackers escolares?

Se hoje as possibilidades tecnológicas dos meios de comunicação tangenciam o infinito, à época de Illich circunscreviam-se a um quadro bastante restrito. Nas décadas de 1940 e 1950, o rádio era assumido em "primeiro pôsto como veículo rápido de comunicação entre os povos" [RBEP, 1945c, p. 337]. Ao lado dele, o cinema também adquiria relevância, mas a televisão só surgiria mais tarde - já na forma de uma TV educativa.

A princípio, o emprego de veículos de mídia em contextos educativos parecia responder majoritariamente a problemas relacionados à necessidade de propaganda e difusão cultural. Vez ou outra, no entanto, referia-se às suas potencialidades educacionais: o rádio, especificamente, aos poucos passava a preencher lacunas decorrentes de uma insuficiência do alcance escolar, função que mais tarde se transmitiria à escola. Tratava-se em ambos os casos, assim, de uma extensão do sistema formal de educação. Já o cinema, utilizado como recurso pedagógico durante a guerra, inspirava outros usos, abrindo margem a intencionalidades educativas que extrapolavam os conteúdos escolares.

Se aquele contexto não oferecia a perspectiva ideal às redes de aprendizagem projetadas por Illich, elas talvez encontrassem guarida perfeita à sua efetivação nas tecnologias digitais de nosso tempo. Por meio das possibilidades de que hoje dispomos, ao menos, os quatro núcleos aventados como parte daquelas redes de aprendizagem estão em plena operação, para além de muitos outros. Se tal suposição for plausível, o paraíso imaginado pelo pensador austríaco, ao menos em parte, habita o contemporâneo. 


\subsection{Da guerra à unificação}

Se a marcha dos vetores traçados até aqui teve em comum o quadro da suposição de uma educabilidade, é tempo de recuar no diagrama para antes da premissa tomada por certa. Afinal, o que se está a recusar quando se afirmam, reiteradamente, as possibilidades educacionais de práticas e espaços variados? A julgar pelos argumentos que percorreram as páginas da revista do Inep, haveria um amplo rol de possibilidades a serem extirpadas.

O pedagogo norte-americano John L. Childs [1944] argumentou, por exemplo, que o processo educativo democrático não pode deixar margem à liberdade individual independentemente de uma condução intencional. Em suas palavras:

Educamos porque preferimos certos aspectos definidos da vida coletiva e da conduta individual, e não outros, que poderiam resultar da experiência livre da criança. Em última análise, a justificação social da escola encontra-se no fato de que a educação formal do ser humano pode aumentar a probabilidade de se obterem tipos de caracteres e modalidades de conduta desejáveis do ponto de vista social. [CHILDS, 1944, p. 206]

A atenção aos processos educativos não escolares, portanto, deveria prestar-se também a vigiá-los, a controlá-los a fim de que cumprissem o que se espera, e não outra coisa. Nesse sentido, a vigilância se estenderia sobretudo ao ócio e ao lazer, de modo a evitar “sua ocupação errada, nociva, senão mesmo criminosa. [...] Graças à recreação inteligente, as pessoas se mantêm felizes, joviais, acessíveis - condições indispensáveis à própria pessoa e ao meio a que pertencem" [REISSIG, 1946, p. 129].

Fecundo ao intento de vigilância (já que difuso, imprevisível), o âmbito recreativo aparecia, pois, como "um ótimo e amplo campo que oferece excelentes oportunidades para uma escola ativa e eficaz" [OESEN, 1954, p. 31]. Nesse último caso, era à escola que se fazia referência, mas a escola de comunidade já aqui mencionada, em perfeita integração com as atividades educativas de seu entorno. O mesmo autor prestou-se a relatar exemplos de iniciativas já em curso nos Estados Unidos, como, entre outros, um programa que envolvia a compra de equipamentos recreativos, a atuação de instrutores de recreação e atividades de veraneio (jogos, campeonatos, concertos, teatro, excursões, práticas esportivas etc.). Tais cooperações entre escola e comunidade existiriam "somente como finalidades e propósitos específicos e limitados", tendo em vista garantir "saúde, segurança, educação, recreação, emprêgo" [OESEN, 1954, p. 32]. 
Já em texto editorial de 1973, intitulado Educação para o lazer, afirmava-se:

[...] à medida em que o homo faber ceder lugar para o homo ludens, é chegado o momento de indagar pelo tipo de formação humana a buscar nas próximas décadas, tendo em vista a preparação das gerações futuras para a sociedade do lazer, em que, liberando a energia despendida no trabalho mecânico e repetitivo, a inteligência humana se deleita no labor criativo, impregnando o trabalho da dimensão de jogo, recreação - o trabalho-lazer" [RBEP, 1973c, p. 574].

Vê-se aí uma concepção de lazer que nada tem de ócio, mas que se encontra intimamente vinculada a uma noção relativa ao próprio trabalho, sendo a educação convocada como tecnologia mediadora a um tal investimento. Se os momentos ociosos deveriam ser alvo de atenção educacional, encontrava-se, enfim, um destino produtivo a lhe ser ofertado.

Curiosamente, o campo do lazer foi também considerado como profícuo a uma educação expandida nas reflexões de Illich (1977, p. 19), que almejava "esclarecer aquelas metas pessoais que poderiam fomentar o advento de uma Era do Lazer (schola) em oposição a uma economia dominada pelas indústrias de serviço". É verdade que Illich não concebia um trabalho-lazer, como vinha mencionado no editorial brasileiro de 1973, mas não deixa de ser inusitado notar uma mesma preocupação educacional com o lazer, em um mesmo período.

Se o lazer, o ócio e a recreação foram objeto a uma vigilância educacional destinada principalmente a modular intencionalidades indesejadas, um contexto bastante diferente figuraria como mote de um intento análogo. De algum modo, ócio e guerra encontraram-se nas tramas de um mesmo projeto educacional: a espreita perante efeitos a serem eliminados do rol de possibilidades.

Em sua análise da crise educacional norte-americana na década de 1950, Hannah Arendt (2007) atribuía àquele contexto uma peculiaridade notável quanto ao que ela considerava ser o inusitado estatuto político do intento educativo ali levado a cabo: era preciso fundar uma pertença nacional em uma população imigrante e heterogênea constituída de cidadãos não nacionalizados a priori. De certo modo, implodindo o que aí se pretendia 
específico, ampliemos o argumento: a todo momento e em todo lugar em que se constituiu uma população, um grupo supostamente coeso, uma nação, não havia cidadãos desde sempre acabados para tanto, não havia tradição nacional a ser perpetuada.

Mas concentremo-nos no contexto brasileiro posterior à Independência de 1822 e em suas circunstâncias mais triviais: findada a condição de colônia, o império nascente herdava um aglomerado humano em nada uniforme. Alegadamente sem uma identidade ou uma unidade nacional, a heterogeneidade de origens daquela multidão muito se assemelhava às circunstâncias vigentes nos Estados Unidos mais ao Norte do mesmo continente, cuja independência havia sido proclamada quase meio século antes. Não por acaso, teria a jovem nação estadunidense sido proeminente alvo de inspiração por parte dos intelectuais brasileiros interessados em adensar raízes ao solo nacional que aqui se forjava.

Entre meados do século XIX e meados do século XX, foi-se produzindo aqui a idéia de que os Estados Unidos ofereciam o melhor espelho para a modernidade no Brasil, pela difusão da crença de que lá estava sendo concretizada a esperança do "homem novo", ou seja, o homem subjetivamente necessário à modernidade. [BONTEMPI JR., 2002/2003, p. 128]

A bem-sucedida formação desse novo homem estaria diretamente relacionada aos rumos que o sistema educacional norte-americano havia adquirido, suposição que ensejou iniciativas reformadoras quanto à educação então efetuada no Brasil. Onde Arendt depois veria crise, portanto, ao menos alguns sul-americanos vislumbravam referência florescente.

Em 1890, o educador e historiador José Veríssimo fez eco a essa maré em sua obra $A$ educação nacional, que rendia louvores à educação cívica daquele país e ao progresso por ela alcançado. Segundo seu argumento, "lá difundiu-se e exaltou-se exemplarmente a educação nacional, que aqui sempre faltou” [BONTEMPI JR., 2002/2003, p. 129]. Fazia-se necessário, portanto, remediar a falta de uma educação nacional no contexto brasileiro, e o exemplo norte-americano era mostra significativa da eficácia de se adotarem parâmetros patrióticos a fim de se construir "uma nação formada por verdadeiros cidadãos" [BONTEMPI JR., 2002/2003, p. 135]. Em outros termos, para que o Brasil se consolidasse como nação, deverse-ia modificar "a postura do povo e, para tal, a educação seria o ponto inicial e o mais importante" [ESPINDOLA; COSTA, 2013, p. 94].

O renomado jurista Rui Barbosa também se consagrou pela defesa da educação nacional naquela passagem de século, centrando na escola "a base para o progresso da nação" 
[ESPINDOLA; COSTA, 2013, p. 96]. Em resposta a tais conclamações, Olavo Bilac e Manoel Bonfim lançariam, em 1910, um manual de ensino intitulado Através do Brasil, fruto do objetivo de "apresentar o país e seu povo a seus leitores, [...] enfatizando os valores básicos necessários a uma coesão nacional e à formação de um sentimento de ‘pertencimento’ à Pátria” [SANTOS; MONTEIRO, 2002, p. 22].

Semelhante expediente anunciado por Veríssimo e Barbosa continuaria a repercutir entre intelectuais brasileiros mais de meio século mais tarde, agora já em um contexto que envolvia questões não apenas de cunho nacional, mas também novas configurações mundiais. Estava-se, então, em meados dos anos 1940.

"A ninguém escapa o fato de que a reconstrução do mundo, em bases mais sólidas, impõe a conseqüente reconstrução dos sistemas educacionais de todos os países", afirmava em 1944 o economista Humberto Bastos, na primeira edição publicada da RBEP. Prosseguia ele: "É por êste motivo que o esforço de planejar semelhante reconstrução torna-se cada vez mais urgente à medida que se aproxima o fim da presente guerra" [BASTOS, 1944, p. 60].

Bastos escrevia às vésperas do cessar-fogo da Segunda Grande Guerra, que oficialmente chegaria a termo em 1945. Iniciava uma tendência recorrente nos textos publicados por aquela revista dali em diante: a necessidade de uma profunda reforma sócioeconômico-cultural a fim de evitar a repetição da barbárie, reforma a ser encabeçada via educação do povo - um antídoto antiguerra.

O campo de intervenção por ele convocado era o dos sistemas formais de ensino, com ênfase na ampliação e na melhoria dos aparatos escolares. Como recomendação pontual, mencionava a necessidade da "extensão do uso do jornal, da revista, da radiodifusão, do cinema, da biblioteca, da galeria de arte, do museu etc.", mas o contexto formal era inequívoco: “em todos os níveis de ensino” [BASTOS, 1944, p. 64].

Naquele mesmo ano, A. Carneiro Leão [1944, p. 167] acrescentaria um importante adendo à reflexão apresentada por Bastos. Em suas palavras, "nazistas, fascistas e marxistas [...] perceberam o poder da educação como fôrça condutora dos povos [...] e trataram de formar a juventude, dentro de seus princípios, até a terem reduzido a instrumento de suas finalidades". Ou seja, a eficácia da educação pós-guerra estaria atestada pela emergência da própria guerra. Uma mesma tecnologia, portanto, cuja aplicabilidade se modularia conforme os valores e propósitos nela investidos. 
Em direção análoga e de forma ainda mais direta, Celso Kelly [1945, p. 319] salientou "a evidência elementar de que, se existe uma educação para a guerra, há-de existir, em polo oposto, uma educação para a paz, para o progresso, para a compreensão e a felicidade entre os homens". De algum modo, o disparo da guerra permanecia como fonte de inspiração àqueles intelectuais, tendo-lhes ensinado que a educação poderia ser estrategicamente ajustada - para o bem ou para o mal - conforme os fins almejados. Em ambos os casos, utilizava-se a via educacional a fim de garantir o estabelecimento amplo e generalizado de determinada conformação - antes supostamente perversa, agora supostamente benéfica.

A promoção da paz e a definição de princípios internacionais comuns (para que não houvesse risco de dissonância entre os países) tornaram-se palavras de ordem entre os autores da $R B E P$ que se debruçaram sobre o assunto, muitas vezes reverberando asserções de intelectuais nativos de países mais diretamente envolvidos nos conflitos bélicos. Do que ali se entrevê, tais preocupações atravessavam da América à Europa, em igual medida.

No caso brasileiro, ao menos, aquelas circunstâncias parecem ter dado carona ao incremento de um projeto que persistia latente desde os pareceres de José Veríssimo e de Rui Barbosa: o estabelecimento de uma identidade nacional. De fato, a prevenção de um novo conflito de grandes proporções era ótimo pretexto para unir um povo em torno de um mesmo propósito; por sua vez, confiar tal tarefa à educação equivalia a instrumentalizar aquela tecnologia de modo a que ela se ajustasse perfeitamente à missão de produzir cidadãos para uma nação. Aliavam-se, assim, uma urgência diligente perante riscos internacionais e um ensejo de coesão interna já presente desde o século anterior.

Teixeira de Freitas [1945, p. 347] nos oferece uma mostra do modo como a questão se formulou: "se quisermos levar o Brasil à vanguarda do movimento de verdadeira reconstrução do mundo, o objetivo essencial é que se assentem, quanto antes, e com clareza, os novos princípios e os propósitos magnânimos que se devem impor à educação nacional". A educação brasileira do pós-guerra, portanto, deveria aliar-se aos princípios de uma educação nacional.

Tais princípios já haviam sido aludidos por Lourenço Filho [1944a] na primeira edição da RBEP. Na ocasião, sob o título A educação, problema nacional, o autor conclamava a assunção de uma consciência educacional, opondo o processo educativo ao que ele denominava forças espontâneas de coesão. Segundo ele, tal consciência seria tardia no 
país, "ao menos na compreensão de que devesse animar o esforço da construção da Nação, pela obra deliberada de instituições educativas de cunho popular" [LOURENÇO FILHO, 1944a, p. 10]. Ainda, o autor ali fazia coincidir, em um mesmo plano, a educação pública e a educação para a Nação: "Sociedade nacional e processo educativo aí aparecem integrados, como expressões de uma obra política comum” [p. 15].

Afora sua preocupação com a construção de uma identidade nacional, Lourenço Filho, já naquele primeiro texto veiculado na revista, demonstrava certa predisposição a considerar dimensões educacionais para além do universo escolar. À mesma época, diria ele que "o processo escolar não tem bastado como recurso normal de educação intencional. A necessidade de educação ou de reeducação está assim presente em todas as idades" [LOURENÇO FILHO, 1945, p. 170]. Daí a defesa então apresentada de que se lançasse mão de instrumentos geralmente reconhecidos como não escolares, a exemplo de bibliotecas públicas, museus de arte e de ciências, concertos, teatro, cinema e rádio. O contexto de seu argumento residia na educação de adultos, pensada diante das circunstâncias do pós-guerra.

Passando pelo mesmo argumento, mas o desviando de volta em direção ao escopo escolar, é Eurico Gaspar Dutra [1946, p. 15] quem se manifesta: "Para se dar maior alcance aos meios de educação extra-escolar, não deve ser esquecido que a influência mais profunda e duradoura da educação advém da ação da escola, e que se realiza, assim ao contacto dos mestres". Como se vê, o futuro Presidente da República (1946-1951), embora reconhecesse outras práticas, voltava a centrar atenção no intento propriamente escolar.

Dez anos mais tarde, em seu discurso de posse como Ministro da Educação e Cultura, Clóvis Salgado [1956] retoma alusão à necessária unidade nacional, dependente, a seu ver, de um amor à Pátria por parte de cada um. "Sem essa misteriosa ligação do homem à terra por laços invisíveis, a árvore da nação não cria raízes nem dá flôres e frutos” [p. 143]. O raciocínio relativo ao plano educativo ministerial que ele ali assumia, no entanto, aproximava-se do reconhecimento da importância de uma educação efetivada fora da escola. Afinal, em suas palavras, "aprende-se de tôdas as formas, em todos os lugares e por todos os meios", e era seu desejo como ministro "cuidar de todos esses veículos de publicidade cultural com o mais vivo interêsse" [p. 143].

Estando atravessadas por vetores discursivos que há pouco apareceram isolados, as relações entre educação pós-guerra e educação nacional configuram uma sutil expressão, na história da RBEP, do vai-e-vem argumentativo em torno das fronteiras do escolar. Julgava-se 
necessário educar todo um povo tendo em vista a edificação de uma nação e sua consequente defesa perante novas ameaças bélicas. Para tanto, ora se conclamava a educação em sua versão escolar, ora se alegava a ineficiência daquela instituição se tomada como estratégia isolada. Era preciso aumentar a oferta educativa, e transitava-se de um polo ao outro conforme parecesse mais abundante a promessa.

Ambos os assuntos (pós-guerra e nacionalismo), tão recorrentes naqueles anos iniciais, posteriormente se diluiriam na profusão de outras preocupações aglutinadas às questões educacionais. O que não significa que teriam deixado de operar, mas apenas que seus caminhos talvez tenham seguido por outros atalhos.

A respeito de tal rarefação, Anísio Teixeira [1952b, p. 35] entrega-nos uma explicação plausível. Convidado a discorrer sobre as conexões entre educação e unidade nacional em certa ocasião no ano de 1952, o então diretor do Inep admite seu constrangimento perante o tema proposto, alegando considerar o problema da unidade nacional como algo de ordem demasiado complexa e diversa, que não se encerra no âmbito educacional. Em seu ponto de vista, a unidade de uma nação não seria algo regular e homogêneo ao longo da história de culturas avançadas e não primitivas, mas sim um estado que

[...] só é conseguido em momentos de perigo e de guerra e, por isto mesmo, só é aceito como coisa provisória e passageira. A unidade não é, assim, um bem senão sob certas condições e em certa quantidade. Demasiada unidade é uma condição de elementarismo, ou, então, nas culturas desenvolvidas, um constrangimento sómente suportável temporariamente, em situações excepcionais de crise ou de guerra. [TEIXEIRA, 1952b, p. 35]

Assim, se a unidade nacional era questão premente naqueles anos ditos críticos por tantos autores preocupados com a condição do país no pós-guerra, ela daria lugar a uma diversificação nacional tão logo as condições de progresso se restabelecessem. É apenas na diversificação cultural, segundo Teixeira [1952b, p. 36], que a educação assume seu papel de fato, sendo ela "uma das condições para a unidade de uma cultura em processo de diversificação ou florescimento". Tanto mais quando se trata de um país constituído por tamanha heterogeneidade: nas palavras de Fernando de Azevedo [1955, p. 8], "não existe, como pode parecer à primeira vista, um só Brasil, mas, dentro dêle, muitos Brasis diferentes num só Brasil nem sempre verdadeiro". 
A uniformidade nacional, portanto, seria tão somente circunstância transitória, o que justificaria seu posterior sumiço como pauta entre os escritos educacionais. Mais que isso, ainda, seria então questão em disputa discursiva perante as transformações atravessadas pelo país, ou então "um escudo para encobrir uma simples atitude conservadora em face de certas mudanças sociais" [p. 43]. Daí que sua recorrente articulação com a educação prestar-se-ia, conforme alegou Teixeira [1952b], a um insistente interesse relativamente à própria educação: "de fato, não estão preocupados com a unidade nacional pròpriamente, mas com o domínio da escola" [p. 43]. Nessa perspectiva, tratava-se mais de uma unificação educacional do que de uma unificação nacional.

\subsection{Da ordem ao direito}

De um modo ou de outro, tratava-se de estabelecer certa unificação (fosse ela educacional, fosse ela nacional) que estivesse no rumo preciso da ordem e do progresso do país. Para tanto, a democracia, a liberdade e o direito estiveram intimamente articulados nas proposições daí decorrentes.

Especificamente no contexto pós-guerra, o regime democrático foi amplamente conclamado como modo de organização política necessária como contraposição à barbárie. Por meio dele, estabeleciam-se a liberdade e o direito de cada indivíduo assumir responsabilidades pelos problemas sociais. Nessa associação, à educação se atribuía papel de mediação, já que é por meio dela que se projeta alcançar o intento traçado. Afinal, "a democracia, como regime político no qual todos podem ser chamados a tôdas as posições, exige a mais ampla e a mais completa educação” [LEÃO, 1944, p. 169].

Asserções análogas aparecem parafraseadas repetidas vezes nas páginas da revista. Afirma-se, por exemplo, que "as democracias precisam, como nenhuma outra forma de governo, de um alto nível educacional da totalidade do povo, pois cada cidadão deve estar preparado para assumir responsabilidades e participar de forma efetiva de sua direção" [REISSIG, 1952a, p. 85]. Ou, então, que todas "as outras formas de sociedade precisam de alguma educação, mas só a democracia precisa de educação para todos e na maior quantidade possível” [TEIXEIRA, 1956d, p. 16].

Segundo Celso Kelly [1955], a educação popular (sobretudo no sentido escolar) deriva a intensificação de seu apelo de duas razões próprias ao mundo moderno: a 
democracia e a técnica. Era porque a democracia e o sufrágio universal demandavam uma valorização moral e social do homem e porque a produção técnica e industrial demandava a valorização econômica e profissional que a educação do povo se tornava urgente. "Nesse mundo, não há mais lugar para a ignorância” [KELLY, 1955, p. 104].

No mesmo passo em que a educação era afirmada como condição necessária à democracia, mais uma vez ganhava destaque explícita sua assunção como constante espontânea. A esse respeito, Anísio Teixeira [1956d, p. 3] estava entre aqueles que afirmam a educabilidade como premissa e ideal democrático: "O ideal, a aspiração da democracia pressupõe um postulado fundamental ou básico, que liga indissolùvelmente educação e democracia. Êsse postulado é o de que todos os homens são suficientemente educáveis, para conduzir a vida em sociedade, de forma a cada um e todos dela partilharem como iguais". Tal postulado fundar-se-ia "na observação comum, esta, confirmada pela ciência, de que o homem é um animal extremamente educável, quiçá o mais educável ou o único verdadeiramente educável" [p. 3].

O autor assume a íntima relação entre democracia e educação (sendo esta condição necessária àquela) e argumenta que é preciso haver uma intencionalidade determinada para que tal relação se leve a efeito.

Daí ser a educação um dos fundamentos da crença democrática e, ao mesmo tempo, uma das razões de se descrer da democracia, por isto mesmo que não vem a escola sendo o desejado instrumento de sua realização, mas, tantas vêzes, um outro meio de se confirmarem e se preservarem as desigualdades sociais. É que não é qualquer educação que produz democracia, mas, sòmente, insisto, aquela que fôr intencionalmente e lucidamente planejada para produzir esse regime político e social. [TEIXEIRA, 1956d, p. 4]

Já Lourenço Filho [1958, p. 35] deu vazão a um paradoxo que interessa examinar mais detidamente: "para que exista democracia é preciso um povo educado; e para que se eduque o povo, será necessário que vigorem instituições democráticas, as quais, para legítima expressão, têm de apoiar-se numa população devidamente preparada para isso". Ou seja, deve-se ter em vista o indivíduo, suas particularidades, suas capacidades, seus desejos, bem como formá-lo a fim de que ele próprio possa julgar os padrões da sociedade em que se insere; ao mesmo tempo, porém, a educação deve estar pautada pelos ideais e valores morais que se quer reforçar. Em outros termos, haveria, assim, "certa ambivalência de posição entre 
a formulação democrática contida no reconhecimento ao direito universal e sua inspiração motivadora, sutilmente aristocrático-religiosa [ABREU, 1963, p. 9].

Para Carneiro Leão [1944, p. 167], a finalidade da educação seria, de fato, estabelecer uma vinculação entre "o bem de cada qual e o bem de todos"; assim se produziria um "regime em que todos os homens ao apelo das leis atuariam rapidamente e, de acordo com a expectativa geral, iriam ao encontro dos inimigos da ordem pública, como se se tratasse de um assunto puramente pessoal". Ora, afinal, a "democracia é a mais integral e a mais exigente de todas as formas políticas. O cidadão em vigília constante é seu melhor soldado" [REISSIG, 1946, p. 33].

Veem-se assim articuladas duas dimensões a princípio supostas como isoladas, mas que passariam, então, a estarem amalgamadas: a individualidade e a coletividade. Daí podermos agora examinar com mais cuidado uma afirmação como a que segue: "A qualquer pessoa assiste a justa aspiração de educar-se" [KELLY, 1955, p. 106].

Ora, é curioso que o ato de educar-se seja apresentado como aspiração pessoal, quando é também - e sobretudo - demanda governamental. No que concerne a tal vinculação subjetiva a problemas de ordem pública e política, a solidariedade, a fraternidade e o voluntarismo foram sentimentos frequentemente referidos na $R B E P$ a reboque de enunciados que visavam estabelecer um elo efetivo entre aquelas duas dimensões. Nesse sentido, afirmava-se, por exemplo, que "todo o sistema deve tender ao preparo cultural e psicológico das novas gerações para as formas superiores de solidariedade humana e lógica, das quais sómente podemos esperar a transição pacífica para a ordem social humanizada que o mundo aguarda" [TEIXEIRA DE FREITAS, 1945, p. 355].

Em suas várias reflexões sobre a educação de adultos, Lourenço Filho com frequência alude à necessidade de se criar um sentimento público favorável à educação. Assim, ele convoca um engajamento na difusão e na realização de tais intentos: "a educação popular não deve ser apenas um empreendimento do Governo, mas, também, um empreendimento do povo" [LOURENÇO FILHO, 1949, p. 130].

Em relação à Campanha de Educação de Adultos, ainda, sempre se salientava a importância do voluntariado, tal como se observa na mensagem presidencial de 1949: "A convocação da solidariedade coletiva, feita pelo Govêrno, em benefício dessa causa, foi correspondida com excepcionais demonstrações de espírito de cooperação de todos os grupos sociais" [RBEP, 1950, p. 93]. Já na de 1950, o argumento se repetia: "há a assinalar o 
trabalho desenvolvido, voluntàriamente, não só por indivíduos, como por igrejas, associações cívicas e culturais, órgãos paraestatais, e emprêsas comerciais e agrícolas" [RBEP, 1950, p. 104].

A democracia, ao menos no conjunto discursivo examinado, mostra-se estratégia retórica com efeito performativo inequívoco: permitir o governo, sobretudo por meio da vinculação subjetiva às causas políticas. Do antifascismo pós-guerra à redemocratização pós1984, passando pelos anos de regime militar, o argumento democrático utilizado como ensejo a mais educação foi precisamente o mesmo, tanto nos textos governamentais, quanto em participações dos vários intelectuais que tiveram seus textos publicados na revista.

Como efeito, no caso específico do direito à educação (tanto escolar, quando para além dela), que pauta reivindicações variadas nos mais diversos contextos e grupos sociais, é possível encontrar um exemplo notável de como se naturaliza uma artificialidade: atribui-se educabilidade ao homem e depois se decreta a educação como direito humano - quando não como desejo que lhe é intrínseco. Afinal, supõe-se que o "acesso à educação é um direito natural. Flui da evidência de ser o homem perfectível, dotado de possibilidades inatas que cabe, pela educação, atualizar e desenvolver" [ARAGÃO, 1965, p. 168].

Mas uma menção ao filósofo e historiador francês Jules Michelet, que viveu no século XIX, pode oferecer nova conotação a tais argumentos.

Michelet perguntava certa vez: "Qual é a primeira parte da política? A educação. A segunda? A educação. E a terceira? A educação". E a seguir acrescentava estas advertências aos legisladores de sua Pátria: "Menos leis, eu vos suplico; mas pela educação fortificai o princípio das leis, fazei que elas sejam aplicáveis e possíveis: formai homens e tudo marchará bem”. [AUGUSTO, 1944, p. 341]

Nessa perspectiva, que afirmava a íntima relação entre política e educação, esta aparece fazendo as vezes de legislação, em nome da manutenção de uma boa marcha aos homens. Sua função seria, portanto, intensamente política: configurava-se em resposta ao problema de como governar mais de forma mais econômica.

Uma asserção análoga apresenta-se já transposta ao contexto atualizado do século XX: Afinal, que "faz todo novo regime ao chegar ao poder? Apoderar-se da escola e de todos os outros meios de ação educativa: a imprensa, a radiotelefonia, o cinema, o teatro, o livro, a cátedra, a tribuna, etc. Se não chega a tudo não é porque não queria senão porque não pode" [REISSIG, 1946, p. 21]. 
Também o discurso político de Gaspar Dutra [1946, p. 13], em 1946, evidenciava a tensão interposta entre um direito à educação e uma demanda governamental: "Em nosso tempo, o povo tem direito aos esclarecimentos da ciência e da técnica. Laboratórios, bibliotecas e gabinetes de estudos devem estar em contacto com a massa ansiosa por aprender. De outra forma não cumprirão a missão social que delas se reclama”.

Em um mesmo golpe de artificialização, a definição da educação como direito também acabava por vincular os cidadãos a problemas de ordem política, em geral sem o evidenciar, incitando a emergência de lutas e demandas por mais direitos, por mais educação. Eis um dos mecanismos operativos da democracia.

Há aí um efeito especialmente paradoxal. Afinal, o direito a algo que passa a ser exigido pelos imperativos de um tempo é tão somente direito de adaptação, de inclusão - em um mundo pacificado, em um país nacionalizado, em uma população alfabetizada, em uma política democrática. Inclusão nas jurisdições do governo, enfim. Daí os contornos suficientes a um paraíso plenamente inclusivo.

Caso a transposição gráfica à forma escrita tenha logrado êxito, o diagrama desenhado agora se revela ser uma peça dotada de alguma complexidade. Nele, vetores vêm e vão; por vezes se esbarram, por vezes caminham juntos em direções paralelas. Por vezes, ainda, tomam rumos divergentes. Nesse traçado difuso, os vários enredos evidenciam caminhos e avizinhamentos não tão óbvios aos enunciados que hoje compõem nosso lastro educacional de sujeitos aprendizes.

Poder-se-ia tomar tal diagrama tão somente como mais uma descrição de eventos pregressos já explorados em demasia no campo da historiografia educacional. E talvez nisso houvesse razão. No entanto, ao menos no que diz respeito à pretensão que o formulou, o diagrama deveria evidenciar como tais enredos articulam formas de um saber possível, definem matrizes de comportamento aos indivíduos e estabelecem, enfim, modos de existência a sujeitos porvir. Em outros termos, estabelecem focos de experiência. Da nossa experiência. 


\section{DESENLACES}

É praticamente unânime a assunção de que há uma educabilidade intrínseca ao homem, como se se tratasse de um ser não apenas disponível e passível aos processos educativos, mas que somente por meio deles se desenvolve e atinge a plena conclusão de seu desenvolvimento - embora tal conclusão seja cada vez mais inatingível, a ser buscada permanente e ininterruptamente. Em outros termos, assume-se que a educabilidade é dimensão antropológica fundamental e que a natureza humana é a de ser educável. Daí a certeza recorrente de que a educação é desde sempre companhia perpétua ao homem, sendo apenas formalizada, modulada e caracterizada a cada época. Como se ela fosse, então, coisa natural a acontecer; como se houvesse, desde o início da aventura humana, espaço prontamente destinado à sua efetivação. Assim se abre espaço, também, para que a educação seja expediente constante na resolução de problemas diversos.

A concepção do homem como ser dotado de educabilidade atravessa um amplo espectro do pensamento filosófico desde há muito tempo, encontrando em Immanuel Kant um de seus importantes propagadores. Opor-se a uma tal evidência pode soar desvario, mas não mais que o espanto provocado por Foucault (2007, p. 222) em sua declaração de que, "até o fim do século XVIII, a vida não existe". Como pode algo como a vida não existir? Ora, porque não havia ainda uma biologia a formular sua existência nas entranhas de um saber possível.

O argumento do pensador francês não esgota aí sua ousadia, mas se utiliza do mesmo recurso para afirmar que tampouco houve, desde sempre, algo como o homem e a própria natureza. "Esquece-se simplesmente que nem o homem, nem a vida, nem a natureza são domínios que se oferecem espontânea e passivamente à curiosidade do saber" (FOUCAULT, 2007, p. 99). Assim como Foucault assume que não havia vida antes que um saber a formulasse, podemos aventar que não havia educabilidade antes que um domínio como o pedagógico a forjasse como alvo de seus saberes e, por extensão, de suas investidas.

Não foi intenção desta pesquisa embrenhar-se pela tarefa desmedida de demonstrar como se operou a invenção de uma educabilidade, com o rigor e a magnitude do exercício analítico praticado por Foucault em relação aos mencionados âmbitos da vida, do homem e da natureza, entre tantos outros que ele se dedicou a analisar. No entanto, ainda que o gesto pretendido tenha sido mais modesto, arriscou-se não abdicar da inspiração no corolário 
foucaultiano. Como premissa analítica, então, supôs-se que um tempo houve em que a educabilidade não existiu.

Afirmar que a educabilidade é coisa inventada não significa dizer que ela hoje não existe. Ao contrário, existe intensamente, existe cada vez mais, existe até mais do que podemos imaginar. É ela o efeito mais bem-acabado de um jogo de veridicção responsável não apenas por converter os homens em sujeitos educáveis, mas também por instituir tempos, espaços e práticas como ocasiões à aprendizagem, de modo que não basta ao sujeito contemporâneo ser educável; é preciso ativar sua educabilidade a todo momento, a todo lugar, a cada gesto. Estaríamos diante, portanto, do "espraiamento de uma educabilidade constante, ininterrupta, que se dá a qualquer momento e em diferentes esferas do espaço social", sobretudo tendo em vista "criar, governar e gerir espacialidades" (AQUINO, 2015, p. 124). Daí a alcunha aqui assumida a tal jogo veridictivo: a intensificação da experiência educacional contemporânea decorreria de uma educabilização.

Eis, enfim, o acontecimento tangenciado do começo ao término do presente trabalho. Em seus enredos nas últimas décadas brasileiras, evidencia-se uma tentacularização, à qual a crise sempre alardeada oferece importante ensejo. Da afirmação da centralidade da escola à sua recusa, passando pela expansão educacional para além dos limites institucionais; da maquinaria da guerra ao anseio pela paz mundial; da ambição governamental pela ordem nacional à apologia do direito educacional de todos e de cada qual: em cada um dos vetores traçados, novos terrenos iam sendo incorporados como solos propícios à efetivação da educabilidade humana.

Peça intensamente ativa desse processo, a intencionalidade adquire lugar de destaque, fazendo-se presente de uma ponta à outra do arquivo: ora se diz ser preciso reconhecer intencionalidades em operação; ora se alega a necessidade de atribuir intencionalidades a processos espontâneos; ora se propõe extirpar intencionalidades distorcidas. Mas a intencionalidade somente se evidencia em sua espessura efetiva quando pareada à educabilidade, seu correlato necessário, apesar de não sempre evidente. Isso porque, em tais enunciados, o recurso à intencionalidade - embora aparentemente tímido, por vezes tratado como mero coadjuvante discursivo - funciona como um dos próprios motores da educabilização posta em marcha.

É porque dotamo-nos a nós próprios de uma educabilidade irredutível, ao mesmo tempo em que imbuímos relações, espaços, meios, tecnologias etc. de virtualidades 
educativas, que passamos a aprender a todo momento, a todo lugar. Como se tal educabilidade estivesse desde sempre aí, e apenas faltasse investi-la de intencionalidade. Como se nos engajarmos em relações de aprendizagem fosse exercitar a liberdade irrestrita de aprender sem mediação formal, institucional, curricular, ideológica etc. Como se a aprendizagem pudesse, de fato, prescindir de um ensino. Como se ela fosse algo essencial à experiência. Mas nem mesmo a experiência é essencial.

Para além de oferecer uma perspectiva analítica delimitada, tais asserções permitem dar conta de importantes desvios que o trato com o arquivo impôs perante as hipóteses iniciais da pesquisa, alguns dos quais já sugeridos ao longo do texto. O principal deles referese à suposição prévia de que o expansionismo pedagógico contemporâneo implicaria necessariamente uma redução da presença escolar no discurso educacional recente.

Sustentar essa suposição após o caminho analítico percorrido seria grave equívoco, além de coincidir com a afirmação de uma crise escolar - a mesma cujas evidências também se pretendeu desmontar. Fato é que as questões relativas à escola permanecem como tema predominante nos periódicos acadêmicos. Ademais, há que se considerar o atual movimento disjuntivo da instituição escolar (AQUINO, 2012), consubstanciado na polivalência de funções hoje atribuídas à escola e por ela assumidas. Nessa direção, o pesquisador português José Augusto Palhares é um dos estudiosos que apontam a existência, ainda hoje, de uma centralidade da forma escolar, a despeito das críticas e das prospecções em contrário. Segundo ele, "o enfrentamento da propalada crise da educação escolar parece querer esboçarse efectivamente com mais escola, só que agora capitalizando e absorvendo para o seu interior algumas das iniciativas mais populares de educação não-escolar" (PALHARES, 2009, p. 71).

As ressalvas aí expostas não deslegitimam a evidência de que, nas páginas periódicas nacionais, a escola hoje convive com pelo menos outros 27 eixos de atuação e reflexão pedagógicas. A educabilização, assim, não visa disputar lugar com a forma escolar. Antes, amalgama-se a ela, evidenciando a agonística própria de um movimento pendular que vai do interior ao exterior institucional, à medida que expande seu escopo de atuação. Escolariza-se e desescolariza-se para os mesmos fins, afinal: em nome de sempre mais educação e, por conseguinte, de mais governamentalidade sobre territórios e populações, em um mundo onde tudo o que se vive é alvo possível de reconhecimento, interpretação e intervenção de cunho pedagógico. 
Embora à primeira vista aparente ser inversa à escolarização, a educabilização é, na verdade, tão somente sua extensão. Daí a emergência imprevista do escolar como uma das questões de primeira ordem: a escola, ao que parece, não perdeu seu posto desde que assumiu a centralidade das funções educativas. Seja pelo avesso, seja pelo direito, é também em relação a ela que as demais práticas educacionais de nosso tempo posicionam-se e anunciamse. Trata-se, no entanto, de uma escola que já não precisa de muros para definir seus limites. Uma escola farta, inchada, alastrada, embora - e porque - sempre insuficiente.

A escolarização teria, assim, ensejado um ideal formativo para o qual ela própria já não é requisito bastante. Ou um cosmopolita inacabado, como diriam Popkewitz, Olsson e Petersson (2009), que formularam essa noção para abarcar o aspecto ininterrupto e infinalizável do ideal de sujeito demandado pela sociedade de aprendizagem.

Assim, embora a investida incessante rumo a uma educabilidade mais intensiva surja como extensão da escolarização, ela responde a problemas distintos daqueles aos quais a escola, por si só, fora solução preponderante. Nesse sentido, é possível apontar algumas problematizações que, desde a década de 1940, vêm ensejando uma ampliação educacional, especificamente no contexto brasileiro: entre outras, a necessidade de se criar um espírito nacional; a urgência em se colocar na direção oposta à que ocasionou grandes conflitos bélicos mundiais; as transformações acarretadas por aumentos demográficos; a exigência de expandir a instrução aos rincões que a escola não atinge; a impossibilidade de garantir escolarização massiva a todos. Em praticamente todos os casos, tratava-se de problemas de ordem política relativos às possibilidades de governamento de uma população. Suas respectivas derivações caminharam no sentido de traçar matrizes veridictivas (via educabilização, vale reafirmar) à configuração de determinados modos de vida.

Se, conforme a inversão da tese de Clausewitz proposta por Foucault (2002), a política é a continuação da guerra por outros meios, não seria a educação a continuação da política por outros meios? Percorridos os enredos traçados, encontramos desenlace possível no desvio de um dos pilares que sustentou a análise de Hannah Arendt sobre a crise educacional norte-americana. Segundo a autora, aquela era ocasião de uma exceção, já que, no referido contexto, a educação extraordinariamente adquiria conotação política, instada a lidar com os imperativos da imigração recente.

Mas eis que a exceção demonstra ser regra. Ao contrário do que afiançava Arendt, a educação, em todas as suas formas, aqui apareceu contígua à política: é seu prolongamento, 
sua coetânea a cada tempo, sua conterrânea a cada canto. Entre educação e política, a tecnologia pedagógica que nutre a educabilização adquire valência mediadora, sendo a educabilidade aquilo que torna possível o governo via educação.

Ao fim e ao cabo, não se trata de, com isso, reafirmar a tautologia do governo, tampouco de denunciar a soberania de uma máquina estatal perante relações humanas distribuídas em um campo de mera ressonância assujeitada. Em vez disso, é preciso lembrar, o governo é tecido da mesma matéria que compõe todos os demais nexos que, por vezes, são supostos fora dele.

Porém, quando o anseio por liberdade e resistência - sobretudo quando autoanunciado contraconduta - encontra vazão nas mesmas soluções traçadas para garantir a ordem e o progresso de um povo, é preciso indagar com alguma desconfiança as regras que regem os jogos entre esses dois polos, não tão extremos assim. Nesse sentido, o legado foucaultiano auxilia-nos a afirmar que liberdade e governo são adjacentes, encontram-se em um mesmo horizonte de efetivação, de modo que não há antecedência de um em relação ao outro.

Por falar em resistência e liberdade, lembremo-nos de duas figuras centrais a esse respeito: Ivan Illich e Paulo Freire. Em vez de esquecimento e de rejeição às respectivas proposições desses autores, é provável que vivemos hoje em um mundo mais freireano e illichiano do que podemos imaginar. Esse mundo, no entanto, talvez não se pareça exatamente com o que ambos gostariam de vislumbrar, mas tal é o preço irredutível de entoar as verdades que nos são contemporâneas, mesmo quando as supomos dotadas de alguma originalidade, de alguma resistência perante uma conjuntura estabelecida.

Seria cruel injustiça, é evidente, atribuir-lhes qualquer intencionalidade equivocada nessa direção; tampouco se trata de ingenuidade. Mais uma vez: ambos têm como álibi as contingências da história, de modo que não são eles os donos dos destinos que seus respectivos espólios viriam a traçar.

O próprio Illich alertou, é preciso reconhecer, quanto a possíveis rumos indesejados de um intento semelhante ao seu: “também creio que o fim da 'era da escolarização' poderia dar início à época da escola global, que só se distinguiria no nome de um manicômio global ou de uma prisão global, na medida em que educação, correção e ajustamento se tornem sinônimos" (ILLICH, 1973, p. 22). 
Em certo sentido, ele aí formula diagnóstico semelhante ao que ora se apresenta. No entanto, algo em suas orientações parece ter deixado margem a um espraiamento educacional que foge aos propósitos anunciados. Talvez esse algo tenha a ver com a perseguição de uma liberdade efetiva e com a suposição de que assim se faria resistência ao poder, alvos estes análogos aos de Paulo Freire. Mas é preciso desconfiança perante uma liberdade e uma resistência que dependem da mesma educabilização empenhada em nome de mais governo.

Paradoxalmente, se a deseducabilização fosse adotada como lema a ser perseguido, talvez se fizesse necessário assumir - na direção oposta à de Illich e à de Freire - um retorno à defesa da escola e de seu monopólio educacional em moldes tradicionais, tal como fazem Jan Masschelein e Maarten Simons (2013) no livro Em defesa da escola: uma questão pública.

Nós nos recusamos, firmemente, a endossar a condenação da escola. Ao contrário, defendemos a sua absolvição. Acreditamos que é exatamente hoje - numa época em que muitos condenam a escola como desajeitada frente à realidade moderna e outros até mesmo parecem querer abandoná-la completamente - que o que a escola é e o que ela faz se torna claro. (MASSCHELEIN; SIMONS, 2013, p. 10)

Para eles, a escola é, antes de mais nada, fonte de tempo livre, conforme a acepção com que na Antiguidade se definia a palavra grega skholé. O que ela faz é transformar conhecimentos e habilidades em bens comuns. Tratar-se-ia, assim, de um lugar caracterizado pela suspensão da produtividade e da utilidade das coisas do mundo. Sem ele, "todo o tempo se torna tempo para aprender, ou seja, tempo produtivo que deve ser otimizado para eficácia e eficiência máximas" (p. 159).

Os espaços e os tempos da vida, afinal, poderiam ser imbuídos de tantas outras dimensões que não as imediatamente educativas que hoje os atravessam. Nesse sentido, se fosse possível clamar por menos educação em vez de exacerbá-la, sua circunscrição na instância tradicionalmente designada para esse fim desoneraria, talvez, o restante do tecido social, abrindo espaço para virtualidades outras e imprevistas ao longo de nossas vidas. Isso nos eximiria, ainda, da disposição incessante à aprendizagem, que hoje nos parece óbvia, mas que, no entanto, está enredada "no apelo para conceber as nossas vidas individuais e coletivas como uma empresa focada na satisfação ótima e máxima de necessidades" (MASSCHELEIN; SIMONS, 2013, p. 158). 
Por ora, contudo, abdiquemos também do desejo de uma redenção via o clamor por menos educação, tendo em vista o que se pôde aprender (como negá-lo?) com o exercício analítico que aqui se arremata. Entranhar-se em vozes alheias do passado expõe-nos o fato flagrante de que nossa própria voz é eco chegado ao presente; de que também estamparemos, enfim, páginas de periódicos acadêmicos para arquivos vindouros.

Atados que estamos aos jogos veridictivos de nosso tempo, talvez não nos reste senão uma cautela obstinada com o que projetamos, com o que propomos, com aquilo contra o que praguejamos. Como diria Foucault (2010, p. 299), "nem tudo é ruim, mas tudo é perigoso". Afinal, as utopias estão sempre à espreita, e seus paraísos não são nada menos que a efetivação dos anseios dos contemporâneos.

Tão difíceis quanto são os começos podem ser os desfechos. À guisa de despedida, evoquemos uma última vez os instigantes seres invisíveis que virtualmente nos acompanharam no trajeto até aqui: "Essa é sua [do dragão] natureza mais sutil, avessa às prisões paradisíacas que idiotamente eu preparava com armadilhas de flores e frutas e fitas, quando ele vinha. Paraísos artificiais que apodreciam aos poucos, paraísos de eu mesmo" (ABREU, 2005, p. 136)

Se, tal como o personagem de Caio Fernando Abreu, puséssemo-nos à espera de dragões cuja presença concreta seria indício de enfim termos conseguido delinear um mundo outro, ao lado de fora de nossos paraísos possíveis, chegaríamos definitivamente solitários a este final de tese, que - lembremos - não foi uma história de dragões, mas da nossa própria experiência de sujeitos aprendizes.

E nós, afinal, seres banais, não somos dragões. Se por vezes o somos, fugindo de prisões paradisíacas, isso dura não mais que um átimo. Na maior parte das vezes, somos filhos do tempo, a execrar infernos e a sonhar paraísos.

Quando se pretende renunciar às redenções, o que resta são exercícios fugazes de habitar o contemporâneo por meio de gestos extemporâneos, à caça de rupturas, de vizinhanças, de estranhamentos, os quais é preciso "contar para mim mesmo, como se fosse ao mesmo tempo o velho que conta e a criança que escuta, sentado no colo de mim" (ABREU, 2005, p. 130). Aí, talvez, uma companhia possível, um desenlace bem-sucedido à 
trilha que se quis percorrer: a forja de uma distância imanente entre nós e nós próprios - o velho que conta e a criança que escuta.

Que haja nesse encontro a inquietude necessária, mas também alguma ternura. 


\section{REFERÊNCIAS}

ABREU, Caio Fernando. Os dragões não conhecem o paraíso. In: Caio 3d: o essencial de década de 1980. Rio de Janeiro: Agir, 2005. p. 129-137.

AFONSO, Almerindo J. Sociologia da educação não-formal: reactualizar um objecto ou construir uma nova problemática? In: ESTEVES, Antonio J.; STOER, Stephen R. (Orgs.). A sociologia na escola. Porto: Editora Afrontamento, 1989. p. 83-96.

. A crise da escola e a educação não-escolar. A Página da Educação, v. 11, n. 110,

2002. Disponível em: <http://www.apagina.pt/?aba=7\&cat=110\&doc=8713\&mid=2>. Acesso em: 10 ago. 2016.

AQUINO, Julio Groppa. Disjunção, dispersão e dissensão da educação contemporânea. In: SARAIVA, Karla; MARCELLO, Fabiana de A. (Orgs.). Estudos culturais e educação: desafios atuais. Canoas: Ed. ULBRA, 2012. p. 138-156.

A educabilidade como nexo da experiência civil contemporânea: aproximações investigativas. Pedagogia y Saberes, Bogotá, n. 43, p. 121-132, jul./dez. 2015.

ARENDT, Hannah. A crise na educação. In: Entre o passado e o futuro. 6. ed. São Paulo: Perspectiva, 2007.

AZANHA, José Mário P. Cultura escolar brasileira: um programa de pesquisa. Revista USP, n. 8, p. 65-69, dez./fev. 1990-1991.

BEILLEROT, Jacky. A sociedade pedagógica. Porto: Rés, 1985.

BORGES, Jorge Luis. Obras completas. v. II (1952-1972). São Paulo: Globo, 2000.

BRASIL. Presidência da República. Lei n 9.394, de 20 de dezembro de 1996, que estabelece as diretrizes e bases da educação nacional. Diário Oficial da União, Brasília, 23 dez. 1996.

. Lei ${ }^{\circ} 5.692$, de 11 de agosto de 1971, que fixa diretrizes e bases para o ensino de $1^{\circ}$ e $2^{\circ}$ graus, e dá outras providências. Diário Oficial da União, Brasília, 12 ago. 1971.

BUCKMAN, Peter (Org.). Educação sem escolas. Rio de Janeiro: Livraria Eldorado Tijuca LTDA, 1973.

CAMOZZATO, Viviane C.; COSTA, Marisa V. Vontade de pedagogia: pluralização das pedagogias e condução de sujeitos. Cadernos de Educação, Pelotas, v. 44, p. 22-44, mar./abr. 2013.

CAMPOS, Bártolo P. Desescolarização da sociedade. Coimbra: Instituto de Estudos Psicológicos e Pedagógicos, 1976.

CANÁRIO, Rui. A escola tem futuro? Das promessas às incertezas. Porto Alegre: Artmed, 2006.

CANÁRIO, Rui; POMBO, Olga. Ivan Illich: um visionário que é preciso reler. Revista Aprender ao Longo da Vida, n. 4, p. 40-47, maio 2005.

COMITÉ INVISÍVEL. Aos nossos amigos. 2015. Disponível em: <https://we.riseup.net/assets/262783/AosNossosAmigos2014.pdf>. Acesso em: 8 ago. 2016. 
COOMBS, Philip H. A crise mundial da educação. 2. ed. São Paulo: Perspectiva, 1986.

CORREIA, José A.; MATOS, Manuel. Da crise da escola ao escolocentrismo. In: STOER, Stephen R.; CORTESÃO, Luiza; CORREIA, José A. (Orgs.). Transnacionalização da educação à "educação" da crise. Porto: Edições Afrontamento, 2001. p. 91-117.

DEACON, Roger; PARKER, Ben. Escolarização dos cidadãos ou civilização da sociedade? In: SILVA, Luiz H. (Org.). A escola cidadã no contexto da globalização. 2.ed. Petrópolis: Vozes, 1998. p. 138-153.

DELEUZE, Gilles; PARNET, Claire. Diálogos. Lisboa: Relógio D’água Editores, 2004.

DEPAEPE, Marc et al. About Pedagogizatiaon: From the Perspective of the History of Education. In: SMEYERS, Paul; DEPAEPE, Marc (Eds.). Educational research 3: the educacionalization of social problems. New York: Springer, 2008. p. 13-30.

DIP, Paula. Para sempre teu, Caio F.: cartas, memórias, conversas de Caio Fernando Abreu/Paula Dip. 2. ed. Rio de Janeiro: Record, 2009.

FARGE, Arlette. O sabor do arquivo. São Paulo: Edusp, 2009.

FAURE, Edgar et al. Aprender a ser. 3. ed. Lisboa: Livraria Bertrand, 1981.

FENDLER, Lynn. Educationalising Trends in Societies of Control: Assessments, ProblemBased Learning and Empowerment. In: SMEYERS, Paul; DEPAEPE, Marc (Eds.). Educational research 3: the educacionalization of social problems. New York: Springer, 2008. p. 47-60.

FOUCAULT, Michel. Nietzsche, a genealogia e a história. In: Microfísica do poder. 21. ed. Rio de Janeiro: Edições Graal, 2005.

. Mesa redonda em 20 de maio de 1978. In: Estratégia, poder-saber. 2. ed. Rio de Janeiro: Forense Universitária, 2006. p. 335-351. (Ditos e escritos IV). 2007.

As palavras e as coisas: uma arqueologia das ciências humanas. 9. ed. São Paulo,

A verdade e as formas jurídicas. Rio de Janeiro: NAU Editora, 2008a.

O nascimento da biopolítica. São Paulo: Martins Fontes, 2008b.

. Vigiar e punir: nascimento da prisão. 37. ed. Petrópolis: Vozes, 2009.

O governo de si e dos outros. São Paulo: Editora WMF Martins Fontes, 2010a.

O sujeito e o poder. In: DREYFUS, Hubert; RABINOW, Paul. Michel Foucault, uma trajetória filosófica: para além do estruturalismo e da hermenêutica. 2. ed. Rio de Janeiro: Forense Universitária, 2010b. p. 273-295.

A política é a continuação da guerra por outros meios. In: Segurança, penalidade e prisão. Rio de Janeiro: Forense Universitária, 2012. p. 29-31. (Ditos e Escritos VIII)

A arqueologia do saber. 8. ed. Rio de Janeiro: Forense Universitária: 2013a.

Conversa com Michel Foucault. In: Repensar a política. Rio de Janeiro: Forense Universitária, 2013b. p. 289-347. (Ditos e escritos VI). 
É importante pensar? In:

Repensar a política. Rio de Janeiro: Forense Universitária, 2013c. p. 354-358. (Ditos e escritos VI).

Polêmica, política e problematizações. In: de Janeiro: Forense Universitária, 2014. p. 219-227. (Ditos e escritos V).

FREIRE, Paulo. Pedagogia do oprimido. 17. ed. Rio de Janeiro: Paz e Terra, 1987. Terra, 1999.

Pedagogia da autonomia: saberes necessários à prática educativa. São Paulo: Paz e

FREIRE, Paulo; ILLICH, Ivan. Diálogos: Paulo Freire - Ivan Illich. Buenos Aires: Busqueta, 1975.

GOHN, Maria da G. Educação não-formal e cultura política. São Paulo: Cortez, 2008.

Educação não formal e o educador social: atuação no desenvolvimento de projetos sociais. São Paulo: Cortez, 2010.

ILLICH, Ivan. A sociedade desescolarizada. In: BUCKMAN, Peter (Org.). Educação sem escolas. Rio de Janeiro: Livraria Eldorado Tijuca LTDA, 1973. p. 22-36.

Celebração da consciência. 2. ed. Petrópolis: Vozes, 1976.

Sociedade sem escolas. 4. ed. Petrópolis: Vozes, 1977.

JOSÉ, Emiliano. O assassinato de Anísio Teixeira. Carta Capital, 13 jan. 2014. Disponível em: <http://www.cartacapital.com.br/sociedade/o-assassinato-de-anisio-teixeira-2603.html>. Acesso em: 20 set. 2016.

LA BELLE, Thomas J. Formal, nonformal and informal education: a holistic perspective on lifelong learning. International Review of Education, v. XXVIII, n. 2, p. 158-175, 1982.

LOCKMANN, Kamila. A educacionalização do social e as implicações na escola contemporânea. Educação Unisinos, São Leopoldo, v. 20, n. 1, p. 58-67, jan./abr. 2016.

MARTINS, Marcos Francisco. Educação não escolar: discussão terminológica e mapeamento dos fundamentos das tendências. Contrapontos, Itajaí, v. 16, n. 1, p. 40-61, jan./abr. 2016.

NOGUERA-RAMÍREZ, Carlos E. Pedagogia e governamentalidade ou Da Modernidade como uma sociedade educativa. Belo Horizonte: Autêntica, 2011.

2014.

A escola atacada: entrevista a Marina Kuzuyabu. Revista Educação, n. 204, abr.

NÓVOA, António. Paulo Freire (1921-1997): a "inteireza" de um pedagogo utópico. In: APPlE, M. W.; NÓVOA, A. (Orgs.). Paulo Freire: política e pedagogia. Porto: Porto Editora, 1998. p. 167-187).

PALHARES, José A. Reflexões sobre o não-escolar na escola e para além dela. Revista Portuguesa de Educação, Braga, v. 22, n. 2, p. 53-84, 2009.

PARK, Margareth Brandini. Educação formal versus educação não-formal: impasses, equívocos e possibilidades de superação. In: PARK, Margareth Brandini; FERNANDES, Renata Sieiro (Orgs.). Educação não formal: contextos, percursos e sujeitos. Campinas: Unicamp, 2005. 
PETITAT, André. Os colégios ou a produção/reprodução de uma cultura geral distintiva. In: p. $76-125$.

Produção da escola / produção da sociedade. Porto Alegre: Artes Médicas, 1994.

POPKEWITZ, Thomas S. The Social, Psychological and Education Sciences: From Educationalization to Pedagogicalization of the Family and the Child. In: SMEYERS, Paul; DEPAEPE, Marc (Eds.). Educational research 3: the educacionalization of social problems. New York: Springer, 2008. p. 171-190.

POPKEWITZ, Thomas S.; OLSSON, Ulf; PETERSSON, Kenneth. Sociedade da aprendizagem, cosmopolitismo, saúde pública e prevenção à criminalidade. Educação e Realidade, Porto Alegre, v. 34, n. 2, p. 73-96, maio/ago. 2009.

RANCIÈRE, Jacques. O mestre ignorante: cinco lições sobre a emancipação intelectual. Belo Horizonte: Autêntica, 2005.

RAVETZ, Joe. Aprendizagem sem escolas: a opinião de um aluno. In: BUCKMAN, Peter (Org.). Educação sem escolas. Rio de Janeiro: Livraria Eldorado Tijuca LTDA, 1973. p. 171-184.

REIMER, Everett. A escola está morta: alternativas em educação. Rio de Janeiro: Livraria Francisco Alvim Editora S.A., 1975.

ROCHA, José Augusto L. As mais recentes informações sobre a morte de Anísio Teixeira.

Secom UnB, 3 mar. 2016.2 Disponível em: <http://www.unb.br/noticias/unbagencia/artigo.php?

id=922> . Acesso em: 20 set. 2016.

ROTHES, Luís. Recomposição induzida do campo da educação básica de adultos: lógicas de apropriação local num contexto político-institucional redefinido. Lisboa: Fundação Calouste Gulbenkian; Fundação para a Ciência e a Tecnologia, 2009.

SIMONS, Maarten; MASSCHELEIN, Jan. 'It Makes Us Believe That It Is About Our Freedom': Notes on the Irony of the Learning Apparatus. In: SMEYERS, Paul; DEPAEPE, Marc (Eds.). Educational research 3: the educacionalization of social problems. New York: Springer, 2008. p. 191-204.

SMEYERS, Paul; DEPAEPE, Marc (Eds.). Educational research 3: the educacionalization of social problems. New York: Springer, 2008.

SZYMBORSKA, Wislawa. Poemas. São Paulo: Companhia das Letras, 2011.

TEIXEIRA, Anísio. A educação e a crise brasileira. São Paulo: Editora Nacional, 1956.

TRILLA BERNET, Jaume. A educación non formal e a cidade educadora: duas perspectivas (unha analítica e outra globalizadora) do universo da educación. Revista Galega do Ensino, n. 24, p. 199-221, 1999.

La educación fuera de la escuela: âmbitos no formales y educación social. Barcelona: Editorial Ariel, 2003.

A educação não-formal. In: ARANTES, Valéria A. (Org.). Educação formal e nãoformal: pontos e contrapontos. São Paulo: Summus, 2008. p. 15-58. 
VARELA, Julia. O estatuto do saber pedagógico. In: SILVA, Tomaz Tadeu da (Org.). O sujeito da educação: estudos foucaultianos. Petrópolis: Vozes, 1994. p. 87-96.

VARELA, Julia; ALVAREZ-URIA, Fernando. Maquinaria escolar. Teoria \& Educação, v. 6, p. 1-33, 1992. Disponível em: <https://www.scribd.com/doc/70553618/Julia-Varela-eFernando-Alvarez-Uria-Maquinaria-Escolar-1>. Acesso em: 8 ago. 2016.

VEIGA-NETO, Alfredo. Algumas raízes da pedagogia moderna. ZORZO, Cacilda M.; SILVA, Lauraci D.; POLENZ, Tamara (Orgs.). Pedagogia em conexão. Canoas: Editora da ULBRA, 2004. p. 65-83.

VEYNE, Paul. Foucault revoluciona a história. In: Brasília: Editora Universidade de Brasília, 1982. p. 151-198.

Como se escreve a história.

VIEIRA, Elisa. A cidade e o governo dos homens: sobre o lastro educacional da urbanidade contemporânea. Dissertação (Mestrado) - Faculdade de Educação, Universidade de São Paulo, 2012. 


\section{FONTES}

\section{A Revista Brasileira de Estudos Pedagógicos (1944-1995)}

ABREU, Jayme. Educação e desenvolvimento: uma colocação do problema na perspectiva brasileira. Revista Brasileira de Estudos Pedagógicos, Brasília, v. 40, n. 91, 1963.

Tentativa de aproximação sociológica ao entendimento de educação no Brasil. Revista Brasileira de Estudos Pedagógicos, Brasília, v. 42, n. 96, 1964.

ADISESHIAH, Malcolm S. Através de revistas e jornais: Perspectivas da educação permanente. Revista Brasileira de Estudos Pedagógicos, Brasília, v. 51, n. 113, 1969.

ALMEIDA JÚNIOR, A. A educação higiênica no lar. Revista Brasileira de Estudos Pedagógicos, Brasília, v. 7, n. 19, 1946.

Antes do "ensino livre". Revista Brasileira de Estudos Pedagógicos, Brasília, v. 15, n. $41,1951$.

O "ensino livre" de Leôncio de Carvalho (I). Revista Brasileira de Estudos Pedagógicos, Brasília, v. 17, n. 45, 1952a.

O "ensino livre" de Leôncio de Carvalho (II). Revista Brasileira de Estudos Pedagógicos, Brasília, v. 17, n. 47, 1952b.

ANDRADE, Primo Nunes de. A educação na era do desenvolvimento. Revista Brasileira de Estudos Pedagógicos, Brasília, v. 30, n. 71, 1958.

ARAGÃO, Raimundo Moniz de. Planejamento para a formação integral do homem. Revista Brasileira de Estudos Pedagógicos, Brasília, v. 43, n. 98, 1965.

AUGuSto, José. Política americana de educação. Revista Brasileira de Estudos Pedagógicos, Brasília, v. 2, n. 6, 1944.

AZEVEDO, Fernando de. Para a análise e interpretação do Brasil. Revista Brasileira de Estudos Pedagógicos, Brasília, v. 24, n. 60, 1955.

Horizontes perdidos e novos horizontes. Revista Brasileira de Estudos Pedagógicos, Brasília, v. 27, n. 65, 1957.

. Documentação: Discurso do Prof. Fernando de Azevedo assumindo a Sec. Da Educação da Prefeitura de São Paulo. Revista Brasileira de Estudos Pedagógicos, Brasília, v. 35, n. 82, 1961.

AZEVEDO, Fernando de et al. Mais uma vez convocados (Manifesto ao povo e ao governo). Revista Brasileira de Estudos Pedagógicos, Brasília, v. 31, n. 74, 1959.

AZEVEDO, Fernando de et al. Manifesto dos educadores democratas em defesa do ensino público (1959). Revista Brasileira de Estudos Pedagógicos, Brasília, v. 75, n. 179/180/ 181, 1994.

BARROS, Maria das Graças Targino, Antônio Teixeira de. Rádio educativa do Piauí: a 
serviço de quê e de quem?. Revista Brasileira de Estudos Pedagógicos, Brasília, v. 73, n. $173,1992$.

BASTOS, Humberto. A educação no após-guerra. Revista Brasileira de Estudos Pedagógicos, Brasília, v. 1, n. 1, 1944.

BECKER, Gretchen. TV-Educativa: balanço das realizações e perspectivas. Revista Brasileira de Estudos Pedagógicos, Brasília, v. 48, n. 108, 1967.

BETTENCOURT, Yolanda. Através de revistas e jornais: Cultura do povo. Revista Brasileira de Estudos Pedagógicos, Brasília, v. 41, n. 94, 1964.

BITTENCOURT, Raul J. Perspectiva histórica dos ideais de educação no Brasil. Revista Brasileira de Estudos Pedagógicos, Brasília, v. 7, n. 20, 1946.

BRITO, Antônio de Oliveira. Documentação: Discurso de posse do Ministro Antônio de Oliveira Brito. Revista Brasileira de Estudos Pedagógicos, Brasília, v. 36, n. 84, 1961.

BRITTO, Jader de Medeiros. Entrevista. Revista Brasileira de Estudos Pedagógicos, Brasília, v. 93, n. 234, (número especial), p. 537-544, maio/ago. 2012.

CAFÉ FILHO, João. Documentação: A palestra presidencial e a educação. Revista Brasileira de Estudos Pedagógicos, Brasília, v. 23, n. 57, 1955.

CARNEIRO, Paulo. Livros em revista: FAURE, Edgar. Apprendre à être. Revista Brasileira de Estudos Pedagógicos, Brasília, v. 60, n. 134, 1974.

CARTA BRASILEIRA DE EDUCAÇÃO DEMOCRÁTICA. Revista Brasileira de Estudos Pedagógicos, Brasília, v. 67, n. 156, 1986.

CARVAlHO FILHO, Antônio Balbino de. Documentação: Posse do Ministro Antônio Balbino de Carvalho Filho na pasta da educação. Revista Brasileira de Estudos Pedagógicos, Brasília, v. 19, n. 50, 1953.

CASTELO BRANCO, Humberto. Documentação: Educação e cultura na mensagem presidencial. Revista Brasileira de Estudos Pedagógicos, Brasília, v. 43, n. 97, 1965a.

Pela democratização do ensino. Revista Brasileira de Estudos Pedagógicos, Brasília, v. 43, n. 98, 1965b.

Documentação: Ensino e educação na mensagem presidencial. Revista Brasileira de Estudos Pedagógicos, Brasília, v. 45, n. 101, 1966.

Documentação: Educação, cultura e pesquisa na mensagem presidencial. Revista Brasileira de Estudos Pedagógicos, Brasília, v. 47, n. 105, 1967.

CHILDS, John L. Democracia e método educacional. Revista Brasileira de Estudos Pedagógicos, Brasília, v. 2, n. 5, 1944

COOMBS, Philip H. Através de revistas e jornais: Desafio ao planejamento educacional. Revista Brasileira de Estudos Pedagógicos, Brasília, v. 51, n. 114, 1969.

CROPESA, Juan. Dois povos: dois polos no ideal educativo. Revista Brasileira de Estudos Pedagógicos, Brasília, v. 9, n. 25, 1946.

CUNHA, Reinaldo de Montalvão de Moraes. Razão e política: a cultura como princípio 
educativo. Revista Brasileira de Estudos Pedagógicos, Brasília, v. 76, n. 182/183, 1995.

DELEÓN, Acher. Conceito atual de educação permanente e seu planejamento. Revista Brasileira de Estudos Pedagógicos, Brasília, v. 51, n. 113, 1969.

FÁVERO, Maria de Lourdes de Albuquerque. Elementos para uma reinterpretação da educação. Revista Brasileira de Estudos Pedagógicos, Brasília, v. 60, n. 133, 1974.

FERNANDES, Florestan. A ciência aplicada e a educação como fatores de mudança cultural provocada. Revista Brasileira de Estudos Pedagógicos, Brasília, v. 32, n. 75, 1959.

FIGUEIREDO, João. Documentação: Educação e cultura na mensagem ao Congresso Nacional. Revista Brasileira de Estudos Pedagógicos, Brasília, v. 63, n. 146, 1980.

FREIRE, Paulo. Escola primária para o Brasil. Revista Brasileira de Estudos Pedagógicos, Brasília, v. 35, n. 82, 1961. (republicado: v. 86, n. 212, 2005)

FREITAS, M. A. Teixeira de. Novos objetivos para a educação no Brasil. Revista Brasileira de Estudos Pedagógicos, Brasília, v. 4, n. 12, 1945.

- Teixeira de. Formação do homem brasileiro como trabalhador cidadão da democracia. Revista Brasileira de Estudos Pedagógicos, Brasília, v. 7, n. 20, 1946.

FREYRE, Gilberto. Sugestões para uma nova política no Brasil: a rurbana. Revista Brasileira de Estudos Pedagógicos, Brasília, v. 27, n. 65, 1957.

FULCHIGNONI, Enrico. A ajuda dos elementos áudio-visuais na educação da América. Revista Brasileira de Estudos Pedagógicos, Brasília, v. 19, n. 49, 1953.

FURTER, Pierre. Educação de adultos e educação extra- escolar nas perspectivas da educação permanente. Revista Brasileira de Estudos Pedagógicos, Brasília, v. 59, n. $131,1973$.

GASPAR DUTRA, Eurico. O problema da educação nacional. Revista Brasileira de Estudos Pedagógicos, Brasília, v. 7, n. 19, 1946.

GEISEL, Ernesto. Documentação: Educação e cultura na mensagem ao Congresso Nacional. Revista Brasileira de Estudos Pedagógicos, Brasília, v. 63, n. 144, 1979.

GOHN, Maria da Glória. Demandas populares urbanas no Brasil: formas educativas da população. Revista Brasileira de Estudos Pedagógicos, Brasília, v. 74, n. 176, 1993.

GÓIS SOBRINHO, Faria. O ensino e a renovação social. Revista Brasileira de Estudos Pedagógicos, Brasília, v. 29, n. 70, 1958.

GRINSPUN, Mirian Paura Sabrosa Zippin. Os novos paradigmas em educação: os caminhos viáveis para uma análise. Revista Brasileira de Estudos Pedagógicos, Brasília, v. 75, n. 179/180/ 181, 1994.

HENQUET, Pierre. Documentação: Missão da UNESCO no Brasil. Revista Brasileira de Estudos Pedagógicos, Brasília, v. 42, n. 96, 1964.

HORTA, José Silvério Baía. Rádio e educação no Brasil. Revista Brasileira de Estudos Pedagógicos, Brasília, v. 59, n. 131, 1973. 
HSIN-PAO, Yang. A educação de adultos nas comunidades rurais. Revista Brasileira de Estudos Pedagógicos, Brasília, v. 14, n. 38, 1950.

ILLICH, Ivan. Como educar sem escolas. Revista Brasileira de Estudos Pedagógicos, Brasília, v. 60, n. 134, 1974.

KELLY, Celso. A educação e o após-guerra. Revista Brasileira de Estudos Pedagógicos, Brasília, v. 3, n. 9, 1945.

Através de revistas e jornais: As artes para o povo. Revista Brasileira de Estudos Pedagógicos, Brasília, v. 7, n. 19, 1946.

Através de revistas e jornais: Reconstrução educacional. Revista Brasileira de Estudos Pedagógicos, Brasília, v. 15, n. 41, 1951.

Documentação: Educação popular e obrigatoriedade do ensino. Revista Brasileira de Estudos Pedagógicos, Brasília, v. 24, n. 59, 1955.

KELLY, Celso; LOURENÇO FILHO, Manuel Bergström. A “Arte Moderna” educa?. Revista Brasileira de Estudos Pedagógicos, Brasília, v. 2, n. 4, 1944.

KUBITSCHEK. Juscelino. Documentação: A educação na mensagem presidencial. Revista Brasileira de Estudos Pedagógicos, Brasília, v. 33, n. 78, 1960.

LEÃO, A. Carneiro. A educação para o após-guerra. Revista Brasileira de Estudos Pedagógicos, Brasília, v. 1, n. 2, 1944.

Instituição de um Departamento Internacional de Educação. Revista Brasileira de Estudos Pedagógicos, Brasília, v. 5, n. 14, 1945.

LEÃO, Emmanuel Carneiro. A viagem da educação. Revista Brasileira de Estudos Pedagógicos, Brasília, v. 63, n. 144, 1979.

LEMME, Paschoal. O Manifesto dos Pioneiros da Educação Nova e suas repercussões na realidade educacional brasileira. Revista Brasileira de Estudos Pedagógicos, Brasília, v. 65, n. 150, 1984.

LEWIN, Helena. Reflexões sobre a educação de adultos como uma prática social do Estado. Revista Brasileira de Estudos Pedagógicos, Brasília, v. 65, n. 149, 1984.

LEYS, Wayne A. R. Unidade e diversidade dos sistemas educacionais. Revista Brasileira de Estudos Pedagógicos, Brasília, v. 40, n. 91, 1963.

LIMA, Lana L. da Gama. Livros em revista: ILLICH, Ivan. Sociedade sem escolas. Revista Brasileira de Estudos Pedagógicos, Brasília, v. 60, n. 134, 1974.

LIMA, Lauro de Oliveira. Livros, revistas e jornais: Por que só a escola não evolui?. Revista Brasileira de Estudos Pedagógicos, Brasília, v. 33, n. 78, 1960.

LOURENÇO FILHO, Manuel Bergström. A educação, problema nacional. Revista Brasileira de Estudos Pedagógicos, Brasília, v. 1, n. 1, 1944a.

Modalidades de educação geral. Revista Brasileira de Estudos Pedagógicos, Brasília, v. 1, n. 2, 1944b.

O problema da educação do adulto. Revista Brasileira de Estudos 
Pedagógicos, Brasília, v. 5, n. 14, 1945.

A Campanha de Educação de Adultos. Revista Brasileira de Estudos Pedagógicos, Brasília, v. 11, n. 29, 1947.

Documentação: Educação de base para adolescentes e adultos; Histórico da educação de adultos no Brasil. Revista Brasileira de Estudos Pedagógicos, Brasília, v. 13, n. 37, 1949.

Variações sobre um velho tema. Revista Brasileira de Estudos Pedagógicos, Brasília, v. 30, n. 71, 1958.

Através de revistas e jornais: A educação cabe a todas as instituições sociais. Revista Brasileira de Estudos Pedagógicos, Brasília, v. 31, n. 74, 1959.

Educação para o desenvolvimento. Revista Brasileira de Estudos Pedagógicos, Brasília, v. 35, n. 81, 1961.

LUZURIAGA, Lorenzo. Origem e desenvolvimento da educação pública. Revista Brasileira de Estudos Pedagógicos, Brasília, v. 10, n. 26, 1947.

MANTOVANI, Juan. Ilusões e realidade do mundo pedagógico. Revista Brasileira de Estudos Pedagógicos, Brasília, v. 4, n. 10, 1945.

MARIANI, Clemente. Documentação: A propósito dos processos de educação democrática. Revista Brasileira de Estudos Pedagógicos, Brasília, v. 27, n. 66, 1957.

MATOS, Luiz Alvez de. Atividades extraclasse. Revista Brasileira de Estudos Pedagógicos, Brasília, v. 25, n. 61, 1956.

MÉDICI, Emílio Garrastazu. Documentação: Educação e cultura na mensagem presidencial. Revista Brasileira de Estudos Pedagógicos, Brasília, v. 53, n. 117, 1970a.

Documentação: Educação e cultura na mensagem presidencial de 1971. Revista Brasileira de Estudos Pedagógicos, Brasília, v. 55, n. 121, 1970 b.

. Documentação: Educação e cultura na mensagem presidencial de 1972. Revista Brasileira de Estudos Pedagógicos, Brasília, v. 57, n. 126, 1972.

MEIRELLES, Hely Lopes. Educação, ensino e cultura no Município. Revista Brasileira de Estudos Pedagógicos, Brasília, v. 25, n. 61, 1956.

MIRANDA, Nicanor. A alimentação nos parques infantis de São Paulo. Revista Brasileira de Estudos Pedagógicos, Brasília, v. 6, n. 16, 1945.

MOREIRA, J. Roberto. Educação, sociedade e ideias educacionais. Revista Brasileira de Estudos Pedagógicos, Brasília, v. 27, n. 65, 1957a.

Funções sociais e culturais da escola - conceito de escola primária. Revista Brasileira de Estudos Pedagógicos, Brasília, v. 27, n. 66, $1957 \mathrm{~b}$.

MOTTA FILHO, Cândido. Documentação: Posse do Ministro Cândido Mota Filho na Pasta da Educação e Cultura. Revista Brasileira de Estudos Pedagógicos, Brasília, v. 22, n. 56, 1954.

Significado político da escola. Revista Brasileira de Estudos Pedagógicos, 
Brasília, v. 24, n. 59, 1955.

OESEN, Edward G. Coordenação dos serviços educacionais da comunidade. Revista Brasileira de Estudos Pedagógicos, Brasília, v. 22, n. 56, 1954.

ORLANDI, J. As "missões culturais". Revista Brasileira de Estudos Pedagógicos, Brasília, v. 3, n. 8, 1945.

PAIVA, Vanilda. Anotações para um estudo sobre populismo católico e educação no Brasil. Revista Brasileira de Estudos Pedagógicos, Brasília, v. 65, n. 151, 1984.

PASSARINHO, Jarbas. Documentação: Uma política de ciência e tecnologia para uma sociedade humanizada. Revista Brasileira de Estudos Pedagógicos, Brasília, v. 52, n. $116,1970$.

PENIDO, Pedro Paulo. Documentação: Discurso de posse do Ministro Pedro Paulo Penido. Revista Brasileira de Estudos Pedagógicos, Brasília, v. 34, n. 79, 1960.

PENTEADO JÚNIOR, Onofre. O governo semi-autônomo da escola secundária e a educação cívico-moral. Revista Brasileira de Estudos Pedagógicos, Brasília, v. 12, n. 32, 1948.

PIERSON, Donald. O processo educacional e o negro brasileiro. Revista Brasileira de Estudos Pedagógicos, Brasília, v. 3, n. 7, 1945.

PIPITONE, Maria Angélica Penatti. Comunicações e informações: Considerações em torno das propostas de escola de tempo integral. Revista Brasileira de Estudos Pedagógicos, Brasília, v. 76, n. 182/183, 1995.

POIGNANT, Raymond. Democracia, expansão econômica e reforma do ensino. Revista Brasileira de Estudos Pedagógicos, Brasília, v. 29, n. 69, 1958.

QUIRINO, Tarcízio. TV-Educativa, suas intenções e seu público. Revista Brasileira de Estudos Pedagógicos, Brasília, v. 55, n. 121, 1970.

RBEP. Brasília, v. 1, n. 1, 1944a.

Documentação: Serviço de rádio-difusão educativa do Ministério da Educação. Revista Brasileira de Estudos Pedagógicos, Brasília, v. 2, n. 6, 1944 b.

Através de revistas e jornais: A educação democrática. Revista Brasileira de Estudos Pedagógicos, Brasília, v. 5, n. 15, 1945a.

Através de revistas e jornais: Bibliotecas circulantes; A função educativa; $O$ sentido educativo das "missões culturais". Revista Brasileira de Estudos Pedagógicos, Brasília, v. 6, n. 18, 1945 b.

Através de revistas e jornais: O rádio e a educação. Revista Brasileira de Estudos Pedagógicos, Brasília, v. 6, n. 17, 1945c.

Documentação: IX Congresso Brasileiro de Educação. Revista Brasileira de Estudos Pedagógicos, Brasília, v. 5, n. 14, 1945d.

Através de revistas e jornais: $\mathrm{O}$ cinema educativo e a experiência americana.

Revista Brasileira de Estudos Pedagógicos, Brasília, v. 7, n. 21, 1946a. 
Documentação: Organização Educacional e Cultural das Nações Unidas. Revista Brasileira de Estudos Pedagógicos, Brasília, v. 7, n. 19, 1946 b.

Através de revistas e jornais: Educação para a democracia. Revista Brasileira de Estudos Pedagógicos, Brasília, v. 10, n. 27, 1947a.

Documentação: Mesa redonda sobre educação popular; Parecer da Comissão de Educação Popular do IBECC. Revista Brasileira de Estudos Pedagógicos, Brasília, v. 10, n. 27, 1947b.

Documentação: As mensagens presidenciais e a educação. Revista Brasileira de Estudos Pedagógicos, Brasília, v. 14, n. 38, 1950.

Documentação: XIV Conferência Internacional de Instrução Pública. Revista Brasileira de Estudos Pedagógicos, Brasília, v. 17, n. 47, 1952.

Através de revistas e jornais: Organização e administração de atividades extraclasse. Revista Brasileira de Estudos Pedagógicos, Brasília, v. 19, n. 50, 1953 a.

. Documentação: XV Conferência Internacional de Instrução Pública. Revista Brasileira de Estudos Pedagógicos, Brasília, v. 19, n. 49, 1953 b.

Documentação: XII Conferência Nacional de Educação. Revista Brasileira de Estudos Pedagógicos, Brasília, v. 26, n. 64, 1956.RBEP. Documentação: O INEP e o ensino público. Revista Brasileira de Estudos Pedagógicos, Brasília, v. 29, n. 70, 1958. 1962.

Editorial. Revista Brasileira de Estudos Pedagógicos, Brasília, v. 37, n. 86,

Editorial: Plano Trienal para a Educação. Revista Brasileira de Estudos Pedagógicos, Brasília, v. 39, n. 89, 1963.

Documentação: Conferência Internacional sobre a Crise Mundial da Educação. Revista Brasileira de Estudos Pedagógicos, Brasília, v. 48, n. 108, 1967a.

Documentação: Educação e cultura na Constituição de 1967. Revista Brasileira de Estudos Pedagógicos, Brasília, v. 47, n. 105, $1967 \mathrm{~b}$. $1967 \mathrm{c}$.

Editorial. Revista Brasileira de Estudos Pedagógicos, Brasília, v. 48, n. 108,

Documentação: Educação na perspectiva do desenvolvimento. Revista Brasileira de Estudos Pedagógicos, Brasília, v. 51, n. 113, 1969.

- Documentação: Educação e cultura na Emenda Constitucional. Revista Brasileira de Estudos Pedagógicos, Brasília, v. 52, n. 116, 1970a. 1970b.

Editorial. Revista Brasileira de Estudos Pedagógicos, Brasília, v. 52, n. 116,

Documentação: Recomendações da $3^{\text {a }}$ Conferência Internacional sobre Educação de Adultos. Revista Brasileira de Estudos Pedagógicos, Brasília, v. 59, n. 131, 1973a.

Documentação: UNESCO: Nova estratégia para a educação. Revista Brasileira de Estudos Pedagógicos, Brasília, v. 59, n. 129, 1973b. 
Editorial: Educação para o lazer. Revista Brasileira de Estudos Pedagógicos, Brasília, v. 59, n. 132, 1973c.

1974.

Editorial. Revista Brasileira de Estudos Pedagógicos, Brasília, v. 60, n. 134,

O Manifesto dos Pioneiros da Educação Nova. Revista Brasileira de Estudos Pedagógicos, Brasília, v. 65, n. 150, 1984.

REAL, Regina M. Os museus de arte na educação. Revista Brasileira de Estudos Pedagógicos, Brasília, v. 2, n. 6, 1944.

Através de revistas e jornais: Os museus e a educação. Revista Brasileira de Estudos Pedagógicos, Brasília, v. 18, n. 48, 1952.

REIS, Sólon Borges dos. Através de revistas e jornais: Crise de crescimento. Revista Brasileira de Estudos Pedagógicos, Brasília, v. 19, n. 49, 1953.

REISSIG, Luís. A educação para a vida nacional. Revista Brasileira de Estudos Pedagógicos, Brasília, v. 7, n. 19, 1946.

A educação: primeiro problema nacional e internacional. Revista Brasileira de Estudos Pedagógicos, Brasília, v. 17, n. 47, 1952a.

Através de revistas e jornais: Uma experiência educacional no Haiti. Revista Brasileira de Estudos Pedagógicos, Brasília, v. 18, n. 48, 1952 b.

RENAULT, Abgar. O sentido autotélico do ensino secundário. Revista Brasileira de Estudos Pedagógicos, Brasília, v. 17, n. 46, 1952. n. 50, 1953.

A crise do ensino. Revista Brasileira de Estudos Pedagógicos, Brasília, v. 19,

Documentação: Posse do Ministro Abgar Renault na Pasta da Educação e Cultura. Revista Brasileira de Estudos Pedagógicos, Brasília, v. 24, n. 60, 1955.

RICHMOND, W. Kenneth. Documentação: A idéia de uma sociedade educativa. Revista Brasileira de Estudos Pedagógicos, Brasília, v. 60, n. 134, 1974.

ROTHEN, José Carlos. O Instituto Nacional de Estudos Pedagógicos: uma leitura da RBEP. Revista Brasileira de Estudos Pedagógicos, Brasília, v. 86, n. 212, p. 189-224, jan./abr. 2005.

SALGADO, Clóvis. Documentação: Posse do Ministro Clóvis Salgado na Pasta da Educação e Cultura. Revista Brasileira de Estudos Pedagógicos, Brasília, v. 25, n. 61, 1956.

SANTOS, Edgard. Documentação: Posse do Ministro Edgard Santos na Pasta da Educação e Cultura. Revista Brasileira de Estudos Pedagógicos, Brasília, v. 22, n. 55, 1954.

SANTOS, Taunay Coelho dos. Documentação: Televisão educativa. Revista Brasileira de Estudos Pedagógicos, Brasília, v. 43, n. 97, 1965.

SAVIANI, Dermeval. O Inep, o diagnóstico da educação brasileira e a Rbep. Revista Brasileira de Estudos Pedagógicos, Brasília, v. 93, n. 234, (número especial), p. 291-322, 
maio/ago. 2012.

SCHWARTZ, B. Reflexões sobre o desenvolvimento da educação permanente. Revista Brasileira de Estudos Pedagógicos, Brasília, v. 51, n. 113, 1969.

SOUZA, Fernando Tude de. Através de revistas e jornais: Os meios áudio-visuais e a educação. Revista Brasileira de Estudos Pedagógicos, Brasília, v. 19, n. 50, 1953.

STODIECK, Henrique. A democracia através da escola primária. Revista Brasileira de Estudos Pedagógicos, Brasília, v. 10, n. 26, 1947.

TARSO, Paulo de. Documentação: Discurso de posse do Ministro Paulo de Tarso. Revista Brasileira de Estudos Pedagógicos, Brasília, v. 40, n. 91, 1963.

TEIXEIRA, Anísio. Documentação: Discurso de posse do Professor Anísio Teixeira no Instituto Nacional de Estudos Pedagógicos. Revista Brasileira de Estudos Pedagógicos, Brasília, v. 17, n. 46, 1952a.

Notas sôbre a educação e a unidade nacional. Revista Brasileira de Estudos Pedagógicos, Brasília, v. 17, n. 47, 1952b.

A crise educacional brasileira. Revista Brasileira de Estudos Pedagógicos, Brasília, v. 19, n. 50, a.

Condições para a reconstrução educacional brasileira. Revista Brasileira de Estudos Pedagógicos, Brasília, v. 19, n. 49, 1953 b.

A educação que nos convém. Revista Brasileira de Estudos Pedagógicos, Brasília, v. 21, n. 54, 1954a.

Padrões brasileiros de educação (escolar) e cultura. Revista Brasileira de Estudos Pedagógicos, Brasília, v. 22, n. 55, 1954 b.

A administração pública brasileira e a educação. Revista Brasileira de Estudos Pedagógicos, Brasília, v. 25, n. 61, 1956a.

A escola pública, universal e gratuita. Revista Brasileira de Estudos Pedagógicos, Brasília, v. 26, n. 64, $1956 b$.

Educação não é privilégio. Revista Brasileira de Estudos Pedagógicos, Brasília, v. 26, n. 63, 1956c.

O processo democrático de educação. Revista Brasileira de Estudos Pedagógicos, Brasília, v. 25, n. 62, 1956d.

A escola brasileira e a estabilidade social. Revista Brasileira de Estudos Pedagógicos, Brasília, v. 28, n. 67, 1957.

Educação - problema da formação nacional. Revista Brasileira de Estudos Pedagógicos, Brasília, v. 29, n. 70, 1958.

Através de revistas e jornais: O ensino cabe à sociedade. Revista Brasileira de Estudos Pedagógicos, Brasília, v. 31, n. 74, 1959.

Revistas: Educação e nacionalismo. Revista Brasileira de Estudos Pedagógicos, Brasília, v. 34, n. 80, 1960. 
Estado atual da educação. Revista Brasileira de Estudos Pedagógicos, Brasília, v. 39, n. 89, 1963.

Através de revistas e jornais: Escola pública é caminho para integração social. Revista Brasileira de Estudos Pedagógicos, Brasília, v. 42, n. 95, 1964.

A longa revolução de nosso tempo. Revista Brasileira de Estudos Pedagógicos, Brasília, v. 49, n. 109, 1968.

Educação: suas fases e seus problemas. Revista Brasileira de Estudos Pedagógicos, Brasília, v. 56, n. 124, 1971a.

Educar para o equilíbrio da sociedade. Revista Brasileira de Estudos Pedagógicos, Brasília, v. 55, n. 122, 1971 b.

TOURAINE, Alain. Educação permanente e sociedade industrial. Revista Brasileira de Estudos Pedagógicos, Brasília, v. 51, n. 113, 1969.

TRIGUEIRO, Durmeval. Um novo mundo, uma nova educação. Revista Brasileira de Estudos Pedagógicos, Brasília, v. 51, n. 113, 1969.

Fenomenologia do processo educativo. Revista Brasileira de Estudos Pedagógicos, Brasília, v. 60, n. 134, 1974.

VARGAS, Getúlio. Documentação: A mensagem presidencial de 1952 e a educação. Revista Brasileira de Estudos Pedagógicos, Brasília, v. 17, n. 45, 1952.

VASCONCELOS, José Vieira de. Universidade e Educação. Revista Brasileira de Estudos Pedagógicos, Brasília, v. 49, n. 109, 1968.

ZUIN, Antônio Álvaro Soares. A pedagogia do oprimido em tempos de industrialização da cultura. Revista Brasileira de Estudos Pedagógicos, Brasília, v. 76, n. 182/183, 1995. 


\section{Os 34 periódicos educacionais (1996-2015)}

ABBONIZIO, Aline. Educação não-escolar de pessoas adultas: ideias e iniciativas de melhorias de comunidades. E-Curriculum, São Paulo, v. 7, n. 3, dez. 2009.

ADAMS, Telmo. Educação na economia solidária: desafios e perspectivas. Educação (UFSM), Santa Maria, v. 39, n. 3, set./dez. 2014.

ADAMS, Telmo; STRECK, Danilo R. Educação Popular e novas tecnologias. Educação (PUCRS), Porto Alegre, v. 33, n. 2, 2010.

ADAMS, Telmo et al. Saberes da experiência no trabalho associado - Associação dos Recicladores de Dois Irmãos. Educação UNISINOS, São Leopoldo, v. 10, n. 2, maio/ago. 2006.

ADAMS, Telmo et al. Educação e economia solidária: uma análise das relações de participação e poder. Educação em Foco (UEMG), Belo Horizonte, v. 18, n. 25, 2015.

ADIB, Pedro Rodolpho Jungers. Cultura popular, educação e lazer: uma abordagem sobre a capoeira e o samba. Práxis Educativa, Ponta Grossa, v. 1, n. 1, 2006 a.

Os velhos capoeiras ensinam pegando na mão. Cadernos CEDES, Campinas, v. 26 n. 68, jan./abr. 2006 b.

AGUIAR, Carmem Maria. Amarrando diferentes faces do saber: cotidiano, brincadeira e educação do povo da Barra. Educação \& Realidade, Porto Alegre, v. 21, n. 2, jan./jun. 1996.

ALBANO, Ana Angélica. Arte e pedagogia: além dos territórios demarcados. Cadernos CEDES, Campinas, v. 30, n. 80, jan./abr. 2010.

ALBUQUERQUE, Rafael Marques de. Letramento eletrolúdico como conscientização: bases teóricas para educar o jogar. Currículo sem Fronteiras, v. 14 n. 2, maio/ago. 2014.

ALEGRIA, João; DUARTE, Rosália. Um sonho, um belo sonho: considerações sobre a gênese das relações entre educação e cinema no Brasil. Revista Diálogo Educacional, Curitiba, v. 5, n. 15, maio/ago. 2005.

ALLIEGRO, Sandra Berenice Villodre. Realidades compartilhadas: organizações vistas como fenômeno cultural - educação, igreja e sociedade. Educação Temática Digital, Campinas, v. 2, n. 1, 2000.

ALMEIDA, Cíntia Borges de; COSTA, Aline Santos. Para a petizada innocente: encanto, diversão e lições de conduta na revista O Tico-Tico (1905-1910). Teias, Rio de Janeiro, v. 16, n. 41, abr./jun. 2015.

ALMEIDA, Cristiane. Oficinas de música: será a formação acadêmica necessária?. Educação (UFSM), Santa Maria, v. 30, n. 1, jan./jun. 2005.

ALMEIDA, Elmir; NAKANO, Marilena. Jovens, territórios e práticas educativas. Teias, Rio de Janeiro, v. 12, n. 26, set./dez. 2011.

ALMEIDA, Evany Bettine de; AZEVEDO-MARTINS, Anna Karenina; NUNES, Viviane Abreu. O corpo como espaço de aprendizagem: reflexões a partir das vivências de um grupo 
de teatro formado por adultos na maturidade. Pro-Posições, Campinas, v. 24, n. 3, set./dez. 2013.

ALMEIDA, Isadora Puntel de; BRANDO, Fernanda da Rocha; JANKE, Nadja. Análise semiótica do potencial didático de vídeo para educação ambiental. Contrapontos, Itajaí, v. 5, n. 2, maio/ago. 2005.

ALMEIDA, Margarete Zacarias Tostes de; REIS, Maria Amélia Gomes de Souza. A sexualidade como patrimônio pessoal e cultural: uma porta aberta por Marabá de Amoedo na perspectiva do museu como espaço educativo e intercultural. Revista Ibero-Americana de Estudos em Educação, v. 10, n. 3, jul./set. 2015.

ALMEIDA, Maria Cristina Alves de. As Tecnologias da Informação e Comunicação (TIC), os novos contextos de ensino-aprendizagem e a identidade profissional dos professores. Revista Brasileira de Estudos Pedagógicos, Brasília, v. 89, n. 221, jan./abr. 2008.

ALMEIDA, Maria Elizabeth Bianconcini de; VALENTE, José Armando. Currículo e contextos de aprendizagem: integração entre o formal e o não-formal por meio de tecnologias digitais. E-Curriculum, São Paulo, v. 12, n. 2, maio/out. 2014.

ALMEIDA, Milton José de. A educação visual da memória: imagens agentes do cinema e da televisão. Pro-Posições, Campinas, v. 10, n. 2, 1999.

A educação visual na televisão vista como educação cultural, política e estética. Educação Temática Digital, Campinas, v. 2, n. 1, 2000.

ALMEIDA, Sara Ferreira de; OLIVEIRA, Maria Waldenez. O mundo da rua educa: processos educativos da população de rua na cidade de São Carlos-SP. Revista da FAEEBA, Salvador, v. 24, n. 43, jan./jun. 2015.

ALTMANN, Helena. A sexualidade adolescente como foco de investimento político-social. Educação em Revista, Belo Horizonte, n. 46, dez. 2007.

ALVES-MAZZOTTI, Aida Judith. Representações dos educadores sociais sobre os "meninos de rua”. Revista Brasileira de Estudos Pedagógicos, Brasília, v. 77, n. 187, set./dez. 1996.

ALVES, Lynn. Jogos eletrônicos e violência: um caleidoscópio de imagens. Revista da FAEEBA, Salvador, n. 22, jul./dez, 2004.

Games e educação: desvendando o labirinto da pesquisa. Revista da FAEEBA, Salvador, n. 40, jul./dez. 2013.

ALVES, Márcio Fagundes; FlORENTINO, Rita de Cássia; DIAS, Rosilana Aparecida. Informática educativa e protagonismo juvenil: o projeto "Jovens Navegando pela Cidade". Teias, Rio de Janeiro, v. 8, n. 14-15, jan./dez. 2007.

ALVES, Maria José Lindgren. Interseção cultura-educação: necessidade pedagógica. Revista Brasileira de Estudos Pedagógicos, Brasília, v. 79, n. 192, maio/ago. 1998.

ALVES, Natália. Políticas de educação-formação para jovens: tensões e contradições. Perspectiva, Florianópolis, v. 26, n. 1, jan./jun. 2008.

ALVES, Nilda; SOARES, Maria da Conceição. Educando o cidadão do futuro e de hoje: pensando a formação de docentes necessária. Educação em Foco (UFJF), Juiz de Fora, v. 18, n. 1, mar./jun. 2013. 
ALVES, Vera Alice Pexe; FREIRE, Ermelinda M. De Lamônica. Ecoturismo: uma prática de educação ambiental. Revista de Educação Pública, Cuiabá, v. 5, n. 7, jan./jun. 1996.

AMARAL, Ana Paula do; MACHADO, Ilma Ferreira. O projeto político-pedagógico e currículo da EFAU: educação para que? E para quem?. Revista Ibero-Americana de Estudos em Educação, v. 9, n. 2, abr./jun. 2014.

AMARAL, Débora Monteiro do; MONTRONE, Aida Victoria Garcia. Educação popular: metodologia de pesquisa como processo educativo. Revista da FAEEBA, Salvador, v. 24, n. 43, jan./jun. 2015.

AMARENTE, Walkyria Mollica do; MORETTI, Ricardo de Souza. Urbanismo para criança - apoio para o estudo do meio em bairros de formação recente. Revista de Educação PUCCampinas, Campinas, n. 14, jun. 2003.

AMÉRICO, Marcos; NAVARI, Shelley Costa; BELDA, Francisco Rolfsen. Gamificação: modelagem de conteúdos para programas e aplicativos educativos no ambiente da TV digital interativa. Revista Ibero-Americana de Estudos em Educação, v. 9, n. 4, out./dez. 2014.

AMIEL, Tel; SOARES, Tiago C. O contexto da abertura: recursos educacionais abertos, cibercultura e suas tensões. Em Aberto, Brasília, v. 28, n. 94, jul./dez. 2015.

ANDRADE, Everaldo Robson de; MELO, José Pereira de. Práticas corporais e velhice: uma relação possível. Educação em Questão, Natal, v. 33, n. 19, set./dez. 2008.

ANDRADE, João Carlos Ribeiro de; SIMAN, Lana Mara de Castro. Práticas culturais e de memórias: cheiro de currículo de história que emerge dos temperos usados nos fazeres de uma alfabetizadora com a EJA. Educação em Foco (UFJF), Juiz de Fora, v. 19, n. 3, nov. 2014/fev. 2015.

ANDRADE, Julia Pinheiro. Narrativas de nosso tempo: notas sobre a canção popular como experiência de formação. Educação em Revista, Belo Horizonte, v. 25, n. 1, abr. 2009.

ANDRADE, Luiz Adolfo de. Conhecimento e simulação o que podemos aprender jogando MMORPG. Teias, Rio de Janeiro, v. 8, n. 14-15, jan./dez. 2007.

ANDRADE, Marcelo. Movimentos sociais, educação e diferenças: definições analíticas e equivalentes práticos. Currículo sem Fronteiras, v. 15, n. 3, set./dez. 2015.

ANDRIOLI, Aline; LÖHR, Suzane Schmidlin. Instituições de acolhimento e seu potencial educativo. Educação em Questão, Natal, v. 49, n. 35, maio/ago. 2014.

ANTONIO, Clésio Acilino; LUCINI, Marizete. Ensinar e aprender na educação do campo: processos históricos e pedagógicos em relação. Cadernos CEDES, Campinas, v. 27, n. 72, maio/ago. 2007.

ANTUNES, Ângela; PADILHA, Paulo Roberto; FEITOSA, Sônia Couto de Souza. O Instituto Paulo Freire e a educação de jovens e adultos. Educação em Revista, Belo Horizonte, n. 32, dez. 2000.

ARANHA, Antônia Vitória Soares. Andragogia: avanço pedagógico ou "pedagogia de resultados" na educação profissional de alunos adultos/trabalhadores?. Educação em Revista, Belo Horizonte, n. 36, dez. 2002. 
ARAÚJO, Cláudio Márcio de; OLIVEIRA, Maria Cláudia Santos Lopes de. Significações sobre desenvolvimento humano e adolescência em um projeto socioeducativo. Educação em Revista, Belo Horizonte, v. 26, n. 3, dez. 2010.

ARAÚJO, Maristela Midlej Silva de. O pensamento complexo: desafios emergentes para a educação on-line. Revista Brasileira de Educação, Rio de Janeiro, v. 12, n. 36, set./dez. 2007.

ARCO, António José Reis do; ARCO, Helena Maria de Sousa Lopes Reis do. Desenvolvimento sustentado e tecnologia educativa: elementos dinamizadores de modificações socioeducativas. Revista Diálogo Educacional, Curitiba, v. 13, n. 40, set./dez. 2013.

ARENHART, Deise. A educação infantil em movimento: a experiência das cirandas infantis no MST. Pro-Posições, Campinas, v. 15, n. 1, 2004.

ARIAS, José Orestes Cardentey; RISCAROLLI, Eliseu. O trabalhador, a educação e a questão de gênero: algumas reflexões. Revista de Educação Pública, Cuiabá, v. 7, n. 11, jan./jul. 1998.

ARONOWITZ, Stanley. Contra a escolarização: educação e classe social. Currículo sem Fronteiras, v. 5, n. 2, jul./dez. 2005.

AROUCA, Lucila Schwantes. O discurso sobre a educação permanente (1960-1983). ProPosições, Campinas, v. 7, n. 2, 1996.

ARROYO, Miguel G. O aprendizado do direito à cidade:, Belo Horizonte: a construção da cultura pública. Educação em Revista, Belo Horizonte, n. 26, dez. 1997.

. A atualidade da educação popular. Revista de Educação Pública, Cuiabá, v. 11, n. 19, jan./jul. 2002.

. Políticas de formação de educadores(as) do campo. Cadernos CEDES, Campinas, v. 27, n. 72, maio/ago. 2007.

Educação popular, saúde, equidade e justiça social. Cadernos CEDES, Campinas, v. 29, n. 79, set./dez. 2009.

ARTUSO, Alysson Ramos. Subjetivação e a educação através da internet. Educar em Revista, Curitiba, n. 26, jul./dez. 2005.

ASCOLANI, Adrián. La prensa periódica catolica y la pedagogía de la persuasión en la Argentina rural de los años 1930: El caso de la provincia de Córdoba. Educação em Questão, Natal, v. 19, n. 5, jan./abr. 2004.

AXT, Margarete et al. Tecnologias digitais na educação: tendências. Educar em Revista, Curitiba, n. especial, 2003.

AYUSO, Maria Luz. Genealogía de una categoría: los Saberes Socialmente Productivos (SSP). Educação UNISINOS, São Leopoldo, v. 10, n. 2, maio/ago. 2006.

BALL, Stephen. Aprendizagem ao longo da vida, subjetividade e a sociedade totalmente pedagogizada. Educação (PUCRS), Porto Alegre, v. 36, n. 2, 2013.

BANDEIRA, Gustavo Andrada. Um currículo de masculinidades nos estádios de futebol. Revista Brasileira de Educação, Rio de Janeiro, v. 15, n. 44, maio/ago. 2010. 
BAQUERO, Rute; FISCHER, Maria Clara Bueno. A educação de jovens e adultos no Brasil: um campo político-pedagógico em disputa. Educação UNISINOS, São Leopoldo, v. 8, n. 15, jul./dez. 2004.

BAQUERO, Rute; HAMMES, Lúcio Jorge. Na contramão da cultura individualista: processos educativos em grupos juvenis e capital social. Educação UNISINOS, São Leopoldo, v. 9, n. 2, maio/ago. 2005.

BARALDI, Claudio. Diálogo, agência e aprendizagem experencial em acampamentos internacionais. Educação e Pesquisa, São Paulo, v. 38, n. 2, abr./jun. 2012.

BARBOSA, Anna Mae Tavares Bastos. A cultura visual antes da cultura visual. Educação (PUCRS), Porto Alegre, v. 34, n. 3, 2011.

BARBOSA, Manuel. Educação e desafios da multiculturalização: uma pedagogia da sociedade civil. Cadernos de Pesquisa, São Paulo, v. 40, n. 141, set./dez. 2010.

BARBOSA, Maria Lúcia Kroeff et al. Um sistema de apoio à educação em saúde voltado a idosos com doenças crônicas. Educação Temática Digital, Campinas, v. 16, n. 2, maio/ago. 2014.

BARBOSA, Sônia Regina da Cal Seixas et al. Rumos do moinho conservação de recursos naturais e qualidade de vida: uma experiência em educação ambiental não formal. Revista de Educação PUC-Campinas, Campinas, n. 26, jan./jun. 2009.

BARCELOS, Valdo. O conhecer, o saber e a ecologia: em tempos de pós-modernidade. Revista de Educação Pública, Cuiabá, v. 12, n. 21, jan/jun. 2003.

Educação ambiental e identidade(s) latino americana: um estudo através da obra literária de Octávio Paz. Educação (PUCRS), Porto Alegre, v. 27, n. 2, 2004.

BARCHI, Rodrigo. Entre a atividade política e a ação policial: sobre a institucionalização das relações que envolvem a educação e o meio ambiente. Pro-Posições, Campinas, v. 25, n. 3 set./dez. 2014.

BARONI, Vivian. Para além do unidimensional: Marcuse e a educação estética. Linhas Críticas, Brasília, v. 21, n. 46, set./dez. 2015.

BARROS, Alessandra Santana. A prática pedagógica em uma enfermaria pediátrica: contribuições da classe hospitalar à inclusão desse alunado. Revista Brasileira de Educação, Rio de Janeiro, n. 12, set./dez. 1999.

BARROS, Daniela Melaré Vieira. Estilos de uso do espaço virtual: como se aprende e se ensina no virtual?. Inter-Ação, Goiânia, v. 34, n. 1, jan./jun. 2009.

Estilos de uso do espaço virtual: novas perspectivas para os ambientes de aprendizagem online. Educação em Foco (UFJF), Juiz de Fora, v. 18, n. 1, mar./jun. 2013.

BARROS FILHO, Delma; BASTOS, Ana Cecília de Sousa B. A formação de conceitos em adultos não escolarizados. Educação e Pesquisa, São Paulo, v. 41, n. 3, jul./set. 2015.

BARROS NETA, Maria da Anunciação P.; SEVERINO, Antonio Joaquim. A participação da televisão na formação da criança. Revista de Educação Pública, Cuiabá, v. 5, n. 7, jan./jun. 1996. 
BASSANI, Patrícia Brandalise Scherer; FRITZ, Rosi Souza. Aprendizagem em/ na rede: comunidades virtuais de aprendizagem em blogs. Revista Diálogo Educacional, Curitiba, v. 13, n. 40, set./dez. 2013.

BATISTA, Patricia Serpa de Souza. A concepção de ética na Educação Popular e o pensamento de Paulo Freire. Educação UNISINOS, São Leopoldo, v. 15, n. 3, set./dez. 2011.

BEISIEGEL, Celso de Rui. Considerações sobre a política da União para a educação de jovens e adultos analfabetos. Revista Brasileira de Educação, Rio de Janeiro, n. 4, jan./abr. 1997.

Alfabetização de jovens e adultos: desafios do século 21. Revista Brasileira de Estudos Pedagógicos, Brasília, v. 84, n. 206/207/208, jan./dez. 2003.

BENFICA, Gregório. O museu e o turismo: a ação educativa para o desenvolvimento sustentável. Revista da FAEEBA, Salvador, n. 18, jul./dez, 2002.

Os desafios da Ecosofia de Guattari para a educação ambiental. Revista da FAEEBA, Salvador, n. 28, jul./dez. 2007.

BERNSTEIN, Basil. A pedagogização do conhecimento: estudos sobre recontextualização. Cadernos de Pesquisa, São Paulo, n. 120, nov. 2003.

BERTANI, Iris Fenner. Formação de espaço educativo para a construção de conhecimento compreensivo sobre o processo de saúde. Revista Ibero-Americana de Estudos em Educação, v. 3, n. 1 e 2, jan./dez. 2008.

BERTI, Andreza Oliveira. Reflexões pedagógicas sobre o cinema. Revista de Educação PUC-Campinas, Campinas, v. 20, n. 1, jan./abr. 2015.

BERTONI, Vera Lúcia. Experiência urbana e conhecimento teatral: romper limites e ampliar espaços. Educação \& Realidade, Porto Alegre, v. 30, n. 2, jul./dez. 2005.

BERTUCCI-MARTINS, Liane Maria. "Conselhos ao povo": educação contra a influenza de 1918. Cadernos CEDES, Campinas, v. 23, n. 59, abr. 2003.

BICCA, Angela Dillmann Nunes; WORTMANN, Maria Lúcia Castagna. Olhando o presente a partir do futuro: a pedagogia do cinema de ficção científica. Educação (PUCRS), Porto Alegre, v. 36, n. 3, 2013.

BLOIS, Marlene M. Educação a distância via rádio e TV educativas: questionamentos e inquietações. Em Aberto, Brasília, v. 16, n. 70, abr./jun. 1996.

BÓGUS, Cláudia Maria. Balanço da produção de conhecimento sobre educação não escolar de adultos: educação popular em saúde, 1998-2006. E-Curriculum, São Paulo, v. 7, n. 3, dez. 2009.

BOMFIM, Luciano Sérgio Ventin. A ontologia humana enquanto referência para uma educação popular emancipatória. Revista da FAEEBA, Salvador, v. 24, n. 43, jan./jun. 2015.

BOMFIN, David Ferreira; SANTOS, Manoel Alves dos. Gestores de empresas de transporte coletivo urbano e as necessidades de aprendizagem. Educação em Foco (UEMG), Belo Horizonte, v. 12, n. 14, 2009. 
BONILLA, Maria Helena; PRETTO, Nelson De Luca. Movimentos colaborativos, tecnologias digitais e educação. Em Aberto, Brasília, v. 28, n. 94, jul./dez. 2015.

BONTEMPI JÚNIOR, Bruno. Brasileiros e não yankees: americanismo e patriotismo em "a educação nacional" (1890), de José Veríssimo. Educação em Foco (UFJF), Juiz de Fora, v. 7, n. 2, set. 2002/fev. 2003.

BONTEMPO, Gínia César et al. Incêndios florestais e material educativo: um meio ou um fim?. Educação em Foco (UFJF), Juiz de Fora, v. 14, n. 2, set. 2009/fev. 2010.

BORGES, Moema da Silva; PINHO, Diana Lúcia Moura; SANTOS, Silvéria Maria dos. As representações sociais das parteiras tradicionais e o seu modo de cuidar. Cadernos CEDES, Campinas, v. 29, n. 79, set./dez. 2009.

BORGES, Thelma Pontes. Função materna, educação e ato educativo. Inter-Ação, Goiânia, v. 34, n. 2, jul./dez. 2009.

BOSCOLO, Gianni. Estado e ONGS: outro mundo é possível? o olhar da periferia. Revista da FAEEBA, Salvador, n. 21, jan./jun, 2004.

BRAGA, Clarissa Bittencourt de Pinho e; TENÓRIO, Robinson Moreira. Ambientes formais e informais de aprendizagem em rede: o professor faz a diferença. Revista da FAEEBA, Salvador, n. 30, jul./dez. 2008.

BRAGA, Fabiana Marini; MELLO, Roseli Rodrigues. Comunidades de aprendizagem e a participação educativa de familiares e da comunidade: elemento-chave para uma educação de êxito para todos. Educação UNISINOS, São Leopoldo, v. 18, n. 2, maio/ago. 2014.

BRANDÃO, Carlos Rodrigues. Vocação de criar: anotações sobre a cultura e as culturas populares. Cadernos de Pesquisa, São Paulo, v. 39, n. 138, set./dez. 2009.

BRITO, Gilmário Moreira. Produção, circulação e leitura de textos religiosos em prosa e verso: educação católica na literatura de folhetos do nordeste. Revista da FAEEBA, Salvador, n. 35, jan./jun. 2011.

BROSTOLIN, Marta Regina; OLIVEIRA, Evelyn Aline da Costa de. Os sentidos do aprender a ser indígena e o viver a infância da criança Terena. Educação em Foco (UEMG), Belo Horizonte, v. 16, n. 22, 2013.

BROUGÈRE, Gilles. Les parcs d'attractions : jeu - divertissement - éducation. Educação e Pesquisa, São Paulo, v. 26, n. 1, jan./jun. 2000.

Lúdico e educação: novas perspectivas. Linhas Críticas, Brasília, v. 8, n. 14, jan./jun. 2002.

BRÜGGER, Paula. Nós e os outros animais: especismo, veganismo e educação ambiental. Linhas Críticas, Brasília, v. 15, n. 29, jul./dez. 2009.

BRUM, Ceres Karam; CUNHA, Jorge Luiz da. A lenda do Angüera: dimensão pedagógica no processo de integração dos guaranis às missões. Educação (UFSM), Santa Maria, v. 22, n. 2, jul./dez. 1997.

Identidades missioneiras: a lenda da Casa de Mbororé. Educação (UFSM), Santa Maria, v. 24, n. 1, jan./jun. 1999. 
BRUZZO, Cristina. Filme "Ensinante": o interesse pelo cinema educativo no Brasil. ProPosições, Campinas, v. 15, n. 1, 2004.

O papel educativo da fotografia de vida selvagem. Educação \& Sociedade, Campinas, v. 34, n. 122, jan./mar. 2013.

BRUZZO, Cristina; GUIDO, Lúcia Estevinho. A ecologia na televisão: o que se espera da TV pública?. Educação Temática Digital, Campinas, v. 14, n. 1, jan./jun. 2012.

BUAES, Caroline Stumpf. Educação financeira com idosos em um contexto popular. Educação \& Realidade, Porto Alegre, v. 40, n. 1, abr./mar. 2015.

BUCK, Sonia; MARIN, Andreia Aparecida. Educação para pensar questões socioambientais e qualidade de vida. Educar em Revista, Curitiba, n. 25, jan./jun. 2005.

BUENO, Divino Alves. Comunicação, mídia e cidadania na prática pedagógica. Inter-Ação, Goiânia, v. 40, n. 3, set./dez. 2015.

BUITRÓN, Edson Paredes. La educación sindical: una opcion desde la liberacion. Revista de Educação PUC-Campinas, Campinas, n. 20, jun. 2006.

BUKOWITZ, Natercia de Souza Lima. Desafios de uma rádio universitária diante do compromisso com a educação e a cidadania. Revista Brasileira de Estudos Pedagógicos, Brasília, v. 81, n. 199, set./dez. 2000.

CABRAL NETO, Antônio; MACEDO FILHO, Francisco Dutra de. Meios de comunicação de massa: o papel legal na disseminação de informações e práticas educativas sobre o meio ambiente e o seu compromisso com os interesses do capitalismo. Educação em Questão, Natal, v. 32, n. 18, maio/ago. 2008.

CAMARGO, Jaquelina de. Crianças na cidade: políticas públicas e universo cultural. Cadernos de Pesquisa, São Paulo, n. 96, fev. 1996.

CAMPOS, Ana Maria de; PACHANE, Graziela Giusti. Vamos fazer da nossa vida uma obra de arte?. Educar em Revista, Curitiba, n. especial 2, 2010.

CAMPOS, Judas Tadeu de. A educação do caipira: sua origem e formação. Educação \& Sociedade, Campinas, v. 32, n. 115, abr./jun. 2011.

CAMPOS, Névio de. Ação católica: o papel da imprensa no processo de organização do projeto formativo da igreja católica no Paraná (1926-1939). Educar em Revista, Curitiba, n. 37, maio/ago. 2010.

CAMPOS, Pedro Celso. Jornalismo ambiental: por uma educação integrada e permanente. Revista de Educação Pública, Cuiabá, v. 16, n. 30, jan./abr. 2007.

CANÁRIO, Rui. Territórios educativos e políticas de intervenção prioritária: uma análise crítica. Perspectiva, Florianópolis, v. 22, n. 1, jan./jun. 2004.

Movimentos sociais e educação popular. Lutas nas empresas, em Portugal, após o 25 de abril. Perspectiva, Florianópolis, v. 26, n. 1, jan./jun. 2008.

Novos (des)caminhos da educação de adultos?. Perspectiva, Florianópolis, v. 31, n. 2, maio/ago. 2013. 
CANDAU, Vera. Movimentos sociais e interculturalidade: desafios para as ações afirmativas. Educação em Foco (UFJF), Juiz de Fora, v. 19, n. 1, mar./jun. 2014.

CAPUTO, Stela Guedes. Aprendendo yorubá nas redes educativas dos terreiros: história, culturas africanas e enfrentamento da intolerância nas escolas. Revista Brasileira de Educação, Rio de Janeiro, v. 20, n. 62, jul./set. 2015.

CARDOSO, Terezinha Maria. Experiências de ensino, pesquisa e extensão no setor de pedagogia do HIJG. Cadernos CEDES, Campinas, v. 27, n. 73, set./dez. 2007.

CARNEIRO, Juliana Daros; ROCHA, Maria Silvia Pinto de Moura Librandi da. Educação não formal e avaliação: possibilidades, limites e desafios. Educação UNISINOS, São Leopoldo, v. 17, n. 2 maio./ago. 2013.

CARNEIRO, Sônia Maria Marchiorato. Fundamentos epistemo-metodológicos da educação ambiental. Educar em Revista, Curitiba, n. 27, jan./jun. 2006.

Ética e educação: a questão ambiental. Revista de Educação PUC-Campinas, Campinas, n. 22, jun. 2007.

CARNEIRO, Sônia Maria Marchiorato; KNECHTEL, Maria do Rosário; MORALES, Angélica Góis. Movimentos sociais, multiculturalismo e educação: desafios para a sociedade contemporânea. Educação (UFSM), Santa Maria, v. 37, n. 3, set./dez. 2012.

CARRANO, Paulo. Jovens, escolas e cidades: desafios à autonomia e à convivência. Teias, Rio de Janeiro, v. 12, n. 26, set./dez. 2011.

CARVALHO, Jaciara de Sá. A natureza das redes e comunidades virtuais de aprendizagem. Educação em Foco (UEMG), Belo Horizonte, v. 12, n. 13, 2009.

CARVALHO, Vanessa Alvim Kling Ferraz de; PETRILLI, Antonio Sergio; COVIC, Amalia Neide. Educação infantil na escola hospitalar: a construção dos saberes escolares. Educação \& Realidade, Porto Alegre, v. 40, n. 4, out./dez. 2015.

CASTELO BRANCO, Maria Teresa. Desenvolvimento do lugar e juventude. Educação UNISINOS, São Leopoldo, v. 8, n. 14, jan./jun. 2004.

CASTILLO, Lester Igor Aliaga. Cuarenta años después ¿La escuela ha muerto?. Revista Ibero-Americana de Estudos em Educação, v. 8, n. 1, jan./mar. 2013.

CASTRO, Amanda Motta; EGGERT, Edla. O processo pedagógico invisível desenvolvido por mulheres: o ensinar e aprender da tecelagem manual nas Minas Gerais. Teias, Rio de Janeiro, v. 15, n. 37, n. especial, 2014.

CAVACO, Carmen. Formação de adultos pouco escolarizados: paradoxos da perspectiva da aprendizagem ao longo da vida. Perspectiva, Florianópolis, v. 31, n. 2, maio/ago. 2013.

CAVALCANTE, Maria Marina Dias; FERREIRA, Eveline Andrade; CARNEIRO, Isabel Magda Said Pierre. A prática educacional do pedagogo em espaços formais e não-formais. Revista Brasileira de Estudos Pedagógicos, Brasília, v. 87, n. 216, maio/ago. 2006.

CAVALIERE, Ana Maria. Escolas de tempo integral versus alunos em tempo integral. Em Aberto, Brasília, v. 21, n. 80, abr. 2009.

CHAVES, Miriam Waidenfeld. As relações entre a escola e o aluno: uma história em transformação. Educação \& Realidade, Porto Alegre, v. 40, n. 4, out./dez. 2015. 
CHEMIN, Beatris Francisca. A educação para e pelo lazer no âmbito municipal. Educação (PUCRS), Porto Alegre, v. 32, n. 2, 2009.

CIOMMO, Regina Célia Di. Educação ambiental e o movimento ecofeminista: O caso da rede mulher de educação e da ONG -Redeh - rede de defesa da espécie humana. Revista de Educação Pública, Cuiabá, v. 12, n. 22, jul./dez. 2003.

CORBALÁN, Maria Alejandra. Los talleres de apoyo escolar: una alternativa complementaria a los processos educativos formales. Pro-Posições, Campinas, v. 8, n. 1, 1997.

CORRÊA, Rosângela Azevedo. A cultura de paz na "Escola de Pais e Filhos". Linhas Críticas, Brasília, v. 10, n. 19, jul./dez. 2004.

CORRÊA, Sandro Alves; MARIN, Andreia Aparecida; OLIVEIRA, Sandra de Fátima. Trabalho e inserção no mundo da vida: significados para os desafios da educação ambiental diante do crescimento da urbanidade. Inter-Ação, Goiânia, v. 33, n. 1, jan./jun. 2008.

COSTA, Anna Maria Ribeiro F. M. da. Os índios Nambiquara do cerrado: trabalho, aprendizagem e saber. Revista de Educação Pública, Cuiabá, v. 13, n. 24, jul./dez. 2004.

COSTA, Carina Martins. A escrita de Clio nos temp(1)os da Mnemósime: olhares sobre materiais pedagógicos produzidos pelos museus. Educação em Revista, Belo Horizonte, n. 47, jun. 2008.

COSTA, Fernando Albuquerque. Comunidades virtuais de aprendizagem: traços, perspectivas de estudo e desafios às instituições educativas. Perspectiva, Florianópolis, v. 30, n. 1, jan./abr. 2012.

COSTA, Marisa Vorraber. Ensinando a dividir o mundo: as perversas lições de um programa de televisão. Revista Brasileira de Educação, Rio de Janeiro, n. 20, maio/ago. 2002.

COSTA, Patrícia Coelho da; PAULILO, André Luiz. Arautos do improvável, pioneiros da radiofonia e da cinematografia educacional no Brasil (1920-1930). Educação em Revista, Belo Horizonte, v. 31, n. 2, abr./jun. 2015.

COUTINHO, Clara Pereira; BOTTENTUIT JUNIOR, João Batista. Rádio e TV na web: vantagens pedagógicas e dinâmicas na utilização em contexto educativo. Teias, Rio de Janeiro, v. 9, n. 16-17, jan./jun. 2008.

COUTINHO, Lidia Miranda; QUARTIERO, Elisa Maria. O merchandising social em Malhação: estratégias socioeducativas para adolescentes. Educação em Questão, Natal, v. 39, n. 25, set./dez. 2010.

COUTINHO, Maria Tereza da Cunha. O discurso pedagógico da televisão: uma discussão sobre dialogia/monologia. Educação em Revista, Belo Horizonte, n. 31, jun. 2000.

COUTO, Edvaldo de Souza. Educação e redes sociais digitais: privacidade, intimidade inventada e incitação à visibilidade. Em Aberto, Brasília, v. 28, n. 94, jul./dez. 2015.

COX, Maria Inês Pagliarin. Pedagogias da língua: muito siso e pouco riso. Cadernos CEDES, Campinas, v. 24, n. 63, maio/ago. 2004.

CRUZ, Daniele. Educação corporativa: a proposta empresarial no discurso e na prática. Educação em Revista, Belo Horizonte, v. 26, n. 2, ago. 2010. 
CRUZ, Dulce Marcia; RAMOS, Daniela Karine; ALBUQUERQUE, Rafael Marques de. Jogos eletrônicos e aprendizagem: o que as crianças e jovens têm a dizer?. Contrapontos, Itajaí, v. 12, n. 1, jan./abr. 2012.

CRUZ, José Adelson. Movimentos sociais e práticas educativas. Inter-Ação, Goiânia, v. 29, n. 2, jul./dez. 2004.

CUNHA, Alda Maria Borges; RODRIGUES, Maria Emilia de C.; MACHADO, Maria Margarida. Alfabetização de jovens e adultos: política pública e movimento popular. Cadernos CEDES, Campinas, v. 27, n. 71, jan./abr. 2007.

CUNHA, Daisy Moreira; ALVES, Wanderson Ferreira. A educação aprende com o homem a continuar o trabalho da vida - educação, trabalho e saúde em algumas experiências fundadoras. Revista da FAEEBA, Salvador, v. 24, n. 43, jan./jun. 2015.

CUNHA, Elizangela Lelis da. Ressocialização: o desafio da educação no sistema prisional feminino. Cadernos CEDES, Campinas, v. 30, n. 81, maio/ago. 2010.

CUNHA, Tania Rocha Andrade; ALVES, Ana Elizabeth Santos. Educação e violência nas relações de gênero: reflexos na família, no casamento e na mulher. Em Aberto, Brasília, v. 27, n. 92, jul./dez. 2014.

CURY, Claudia Engler. O papel dos intelectuais na configuração da brasilidade e das políticas de educação/cultura nos anos trinta do século XX. Educação em Foco (UFJF), Juiz de Fora, v. 7, n. 2, set. 2002./fev. 2003.

D’ÁVILA, Cristina. Conhecimento compartilhado no espaço colaborativo das comunidades virtuais de aprendizagem. Revista da FAEEBA, Salvador, n. 22, jul./dez, 2004.

DALBEN, André; SOARES, Carmen Lúcia. Uma educação pela natureza: vida ao ar livre e métodos terapêuticos nas colônias de férias infantis do Estado de, São Paulo (1940). ProPosições, Campinas, v. 22, n. 1, jan./abr. 2011.

DARON, Vanderléia Laodete Pulga. A dimensão educativa da luta por saúde no Movimento de Mulheres Camponesas e os desafios político-pedagógicos para a educação popular em saúde. Cadernos CEDES, Campinas, v. 29, n. 79, set./dez. 2009.

DEBALD, Blasius Silvano. A educação informal da juventude na diocese de santa cruz do sul - 1959/1986. Educação (UFSM), Santa Maria, v. 26, n. 2, jul./dez. 2001.

DELUIZ, Neise; GONZALEZ, Wânia R. C.; NOVICKI, Victor. Sociedade civil e as políticas de educação de jovens e adultos: a atuação das ONGS no Rio de Janeiro. Educação e Cultura Contemporânea, Rio de Janeiro, v. 3, n. 5, jan./jun. 2006.

DELUIZ, Neise et al. Trabalho, meio ambiente e educação: um estudo das práticas educativas das ONGs. Educação e Cultura Contemporânea, Rio de Janeiro, v. 1, n. 1, jan./jun. 2004.

DI PIERRO, Maria Clara. Ação Educativa - Assessoria, Pesquisa e Informação: uma organização não governamental na investigação em educação de jovens e adultos. Educação em Revista, Belo Horizonte, n. 32, dez. 2000.

DI PIERRO, Maria Clara; HADDAD, Sérgio. Transformações nas políticas de educação de jovens e adultos no Brasil no início do terceiro milênio: uma análise das agendas nacional e internacional. Cadernos CEDES, Campinas, v. 35, n. 96, maio/ago. 2015. 
DI PIERRO, Maria Clara; JOIA, Orlando; RIBEIRO, Vera Masagão. Visões da educação de jovens e adultos no Brasil. Cadernos CEDES, Campinas, v. 21, n. 55, nov. 2001.

DIAS, Ângela Correia. Processos comunicacionais da cultura jovem na rede social do ciberespaço. Educar em Revista, Curitiba, n. 26, jul./dez. 2005.

DIAS, Denise Gamio; OLIVEIRA, Neiva Afonso; OLIVEIRA, Avelino da Rosa. Sensibilizar a natureza humana interior: a unidade homem-natureza e a educação ambiental. Linhas Críticas, Brasília, v. 19, n. 39, maio/ago. 2013.

DICKMANN, Ivo; CARNEIRO, Sônia Maria Marchiorato. Paulo Freire e educação ambiental: contribuições a partir da obra Pedagogia da Autonomia. Revista de Educação Pública, Cuiabá, v. 21, n. 45, jan./abr. 2012.

DIETRICH, Jochen. A oficina do olhar - a abordagem histórico-cultural na construção de uma pedagogia dos museus: o exemplo do m|i|mo - Museu da Imagem em Movimento de Leiria, Portugal. Teias, Rio de Janeiro, v. 3, n. 5, jan./jun. 2002.

DIETZSCH, Mary Júlia Martins. Recontando histórias: vozes e silêncios de meninos de rua. Cadernos de Pesquisa, São Paulo, n. 104, jul. 1998.

. Leituras da cidade e educação. Cadernos de Pesquisa, São Paulo, v. 36, n. 129, set./dez. 2006.

DINIS, Nilson Fernandes. Educação, cinema e alteridade. Educar em Revista, Curitiba, n. 26, jul./dez. 2005.

DOMINGOS, Ana Maria; MARTINS, Mirian Teresa de Sá Leitão. Além dos espaços escolares convencionais, mulheres idosas em um grupo de alfabetização e apoio escolar. Teias, Rio de Janeiro, v. 9, n. 18, jul./dez. 2008.

DUARTE, Rosália; ALEGRIA, João. Formação estética audivisual: um outro olhar para o cinema a partir da educação. Educação \& Realidade, Porto Alegre, v. 33, n. 1, jan./jun. 2008.

DUARTE, Rosália; LEITE, Camila; MIGLIORA, Rita. Crianças e televisão: o que elas pensam sobre o que aprendem com a tevê. Revista Brasileira de Educação, Rio de Janeiro, v. 11, n. 33, set./dez. 2006.

DUARTE, Rosália; SANTIAGO, Ilana Eleá. Panorama mundial dos estudos em educação e comunicação. Educação e Cultura Contemporânea, Rio de Janeiro, v. 4, n. 7, jan./jun. 2007.

DULLO, Eduardo. Paulo Freire e a produção de subjetividades democráticas: da recusa do dirigismo à promoção da autonomia. Pro-Posições, Campinas, v. 25, n. 3 set./dez. 2014.

DURRIVE, Louis. Formação, trabalho, juventude: uma abordagem ergológica. ProPosições, Campinas, v. 13, n. 3, 2002.

DUVOISI, Ivane; SOUZA, Moacir Langoni de; GALIAZZI, Maria do Carmo. A pesquisa em sala de aula como metodologia para complexificar o discurso ambiental. Contrapontos, Itajaí, v. 3, n. 1, jan./abr. 2003. 
ESPERANÇA, Joice Araújo; DIAS, Cleuza Maria Sobral. Das infâncias plurais a uma única infância: mídias, relações de consumo e construção de saberes. Educação (UFSM), Santa Maria, v. 33, n. 1, jan./abr. 2008.

ESPINDOLA, Maíra Lewtchu; COSTA, Jean Carlo de Carvalho. A circulação de ideias no Brasil: a educação como regeneração da nação. Cadernos de Educação, Pelotas, n. 45, maio/ago. 2013.

FALKEMBACH, Elza Maria Fonseca. MST, "escola da vida" em movimento. Cadernos CEDES, Campinas, v. 27, n. 72, maio/ago. 2007.

FANTIN, Maristela. Entre práticas, sujeitos e experiência: Pesquisas em Educação Popular nos anos 80-90. Revista de Educação Pública, Cuiabá, v. 7, n. 11, jan./jul. 1998.

FARIA, Ana Beatriz Goulart de. Por outras referências no diálogo arquitetura e educação: na pesquisa, no ensino e na produção de espaços educativos escolares e urbanos. Em Aberto, Brasília, v. 25, n. 88, jul./dez. 2012.

FARIA, Ana Lúcia Goulart de. A contribuição dos parques infantis de Mário de Andrade para a construção de uma pedagogia da educação infantil. Educação \& Sociedade, Campinas, v. 20, n. 69, dez. 1999.

FÁVERO, Osmar. Materiais didáticos para a educação de jovens e adultos. Cadernos CEDES, Campinas, v. 27, n. 71, jan./abr. 2007.

FÁVERO, Osmar; FREITAS, Marinaide. A educação de adultos e jovens e adultos: um olhar sobre o passado e o presente. Inter-Ação, Goiânia, v. 36, n. 2, jul./dez. 2011.

FELÍCIO, Helena Maria dos Santos. A instituição formal e a não-formal na construção do currículo de uma escola de tempo integral. Educação em Revista, Belo Horizonte, v. 27, n. 3, dez. 2011.

FERNANDES, Adriana Hoffmann. A televisão e o cenário do conhecimento das crianças na contemporaneidade. Teias, Rio de Janeiro, v. 4, n. 7, jan./dez. 2003.

FERNANDES, Célia Regina Delácio; PAULA, Flávia Ferreira de. Literatura, infância e o projeto Literatura Em Minha Casa. Teias, Rio de Janeiro, v. 16, n. 41, abr./jun. 2015.

FERNANDES, Ciane. Esculturas líquidas: a pré-expressividade e a forma fluida na dança educativa (pós) moderna. Cadernos CEDES, Campinas, v. 21, n. 53, abr. 2001.

FERNANDES, Gustavo Nicolini; LEITE, Érica Ferrazoli Devienne. Odontologia em saúde coletiva e atividades pedagógicas orientadas à saúde através de jogos e brincadeiras. Revista de Educação PUC-Campinas, Campinas, n. 14, jun. 2003.

FERNANDES, Renata Sieiro. Memórias de menina. Cadernos CEDES, Campinas, v. 22, n. 56, abr. 2002.

FERRARI, Anderson. Revisando o passado e construindo o presente: o movimento gay como espaço educativo. Revista Brasileira de Educação, Rio de Janeiro, n. 25, jan./abr. 2004.

FERRAZ, Lucimare et al. Adolescentes do meio rural: riscos, educação ambiental e autocuidado. Educação Temática Digital, Campinas, v. 16, n. 3, set./dez. 2014. 
FERREIRA, Deller James; SANTOS, Gilberto Lacerda dos. Avaliação das interações na aprendizagem colaborativa criativa via web. Revista Diálogo Educacional, Curitiba, v. 8, n. 25, set./dez. 2008.

FERREIRA, Gilmar Leite; NÓBREGA, Terezinha Petrucia da; PINHEIRO, Walter. O sertão educa. Educação em Questão, Natal, v. 48, n. 34, jan./abr. 2014.

FERREIRA, Gustavo Lopes; CARVALHO, Daniela Franco. O enfoque educativo no rastro da constituição dos museus de ciências. Revista de Educação Pública, Cuiabá, v. 23, n. 52, jan./abr. 2014.

FERREIRA, Mayra Fernanda. Infância e mídia: reflexões sobre produtos culturais para crianças. Contrapontos, Itajaí, v. 7, n. 3, set./dez. 2007.

FERREIRA, Simone de Lucena. Das imagens do mundo ao mundo das imagens: as possibilidades da TV digital para a educação. Educação em Questão, Natal, v. 37, n. 23, jan./abr. 2010.

FERREIRA, Simone de Lucena; BIANCHETTI, Lucídio. Televisão on-line e possibilidades para a educação interativa. Educação e Cultura Contemporânea, Rio de Janeiro, v. 2, n. 3, jan./jun. 2005.

FIALHO, Francisco Antonio Pereira; MATOS, Elizete Lúcia Moreira. Educação, comunicação e tecnologias: uma nova geometria para os diferentes espaços educativos. Revista Diálogo Educacional, Curitiba, v. 4, n. 12, maio/ago. 2004.

FISCHER, Maria Clara Bueno. Um lugar para a educação numa prática sindical transformadora. Estudos Leopoldenses, São Leopoldo, v. 3, n. 4, jan./jun. 1999.

Produção e legitimação de saberes no e para o trabalho e educação cooperativa. Educação UNISINOS, São Leopoldo, v. 10, n. 2, maio/ago. 2006.

FISCHER, Maria Clara Bueno; GODINHO, Ana Cláudia Ferreira. Elementos da trajetória da educação do trabalhador no Brasil, no século XX, com base em pesquisas discentes de PósGraduação. E-Curriculum, São Paulo, v. 7, n. 3, dez. 2009a.

Experiências e projetos de educação do trabalhador no Brasil: balanço da produção discente sobre a ação sindical. E-Curriculum, São Paulo, v. 7, n. 3, dez. 2009b.

FISCHER, Maria Clara Bueno; HANNAH, Janet. Estudando o fenômeno da globalização: um estudo comparativo sobre o papel da educação sindical na Grã-Bretanha e no brasil. Estudos Leopoldenses, São Leopoldo, v. 2, n. 2, jan./jul. 1998.

FISCHER, Maria Clara Bueno; ZIEBELL, Clair Ribeiro. Mulheres e seus saberes engravidando uma outra economia. Cadernos de Educação, Pelotas, n. 25, jul./dez. 2005.

FISCHER, Nilton Bueno. Educação popular em "tempos" de mulheres papeleiras. Cadernos CEDES, Campinas, n. 38, 1996.

Trabalho e autonomia. Construção do possível entre os trabalhadores, homens e mulheres, recicladores da Associação Ecológica Rubem Berta de, Porto Alegre (RS). Educação UNISINOS, São Leopoldo, v. 10, n. 2, maio/ago. 2006.

Educação não escolar de jovens e adultos e educação ambiental: um balanço da produção de conhecimentos. E-Curriculum, São Paulo, v. 7, n. 3, dez. 2009a. 
Educação não-escolar de adultos e educação ambiental: um balanço da produção de conhecimentos. Revista Brasileira de Educação, Rio de Janeiro, v, 14, n. 41, maio/ago. $2009 b$.

FISCHER, Rosa Maria Bueno. "Técnicas de si” na TV: a mídia se faz pedagógica. Educação UNISINOS, São Leopoldo, v. 4, n. 7, jul./dez. 2000.

O dispositivo pedagógico da mídia: modos de educar na (e pela) TV. Educação e Pesquisa, São Paulo, v. 28, n. 1, 2002a.

Uma análise foucaultiana da TV: das estratégias de subjetivação na cultura. Currículo sem Fronteiras, v. 2, n. 1, jan./jun. 2002 b.

FISCHMAN, Gustavo. Intelectuais, burros ou super-professores? Os educadores populares em tempos de ajuste estrutural. Currículo sem Fronteiras, v. 2, n. 2, jul./dez. 2002.

FIUZA, Alexandre Felipe. A censura musical e seu potencial educativo na ditadura portuguesa das décadas de 60 e 70. Acta Scientiarum. Education, Maringá, v. 35, n. 1, jan./jun. 2013.

FLEURI, Reinaldo Matias. Educação intercultural, gênero e movimentos sociais no Brasil. Educar em Revista, Curitiba, n. especial, 2003.

FONSECA, Fabíola Simões Rodrigues da; OLIVEIRA, Leandro Gonçalves. Concepções de meio ambiente dos educadores ambientais do Zoológico de Goiânia: implicações nas atividades e contribuições para a formação do sujeito ecológico?. Educar em Revista, Curitiba, n. 41, jul./set. 2011.

FONSECA, Laura Souza. Apoio socioeducativo, enraizamento do infantojuvenil?(com)vivências em comunidades da periferia urbana. Cadernos de Educação, Pelotas, n. 32, jan./abr. 2009.

FONSECA, Lázaro Emanuel Souza. Os jogos eletrônicos de simulação: aprendendo com o The Sims. Revista da FAEEBA, Salvador, n. 23, jan./jun, 2005.

FONTES, Rejane de Souza. A escuta pedagógica à criança hospitalizada: discutindo o papel da educação no hospital. Revista Brasileira de Educação, Rio de Janeiro, n. 29, maio/ago. 2005.

FONTES, Rejane de Souza; VASCONCELLOS, Vera Maria Ramos de. CEDERJ. Cadernos CEDES, Campinas, v. 27, n. 73, set./dez. 2007.

FOOKEN, Insa. A formação na maturidade como apropriação da própria história de vida. Educação \& Realidade, Porto Alegre, v. 40, n. 1, abr./mar. 2015.

FORT, Mônica Cristine. Televisão educativa: a audiência como fator de construção de uma identidade pedagógico-cultural. Revista Diálogo Educacional, Curitiba, v. 5, n. 15, maio/ago. 2005.

FORTE, Glenilce Maria de Sousa; ROCHA, Sinara Socorro Duarte. Quem conhece? Discutindo as possibilidades pedagógicas do orkut. Educação Temática Digital, Campinas, v. 9, n. 1, 2007.

FORTUNATO, Ivan. Meio-ambiente ou (meio-ambiente): o desafio da educação frente ao paradoxo ambiental. Educação Temática Digital, Campinas, v. 16, n. 3, set./dez. 2014. 
FRANÇA FILHO, Genauto Carvalho; AGUIAR, Vicente. Catedral, bazar e educação: uma análise do modelo aberto de aprendizagem dos hackers. Em Aberto, Brasília, v. 28, n. 94, jul./dez. 2015.

FRANCO, Dalva de Souza. A gestão de Paulo Freire à frente da Secretaria Municipal de Educação de, São Paulo (1989 - 1991) e suas consequências. Pro-Posições, Campinas, v. 25, n. 3 set./dez. 2014.

FRANCO, Francisco Carlos; PRADOS, Rosalia Maria Netto; BONINI, Luci Mendes. Cultura, cidadania e patrimônio cultural: interfaces entre a escola, a cidade e as políticas culturais na cidade de Guararema, SP. Perspectiva, Florianópolis, v. 33, n. 1, jan./abr. 2015.

FRANCO, Jussara Botelho; MOLON, Susana Inês. Aproximações entre educação não formal e trabalho mediadas por uma perspectiva socioambiental e de classe. Cadernos de Educação, Pelotas, n. 30, jan./jun. 2008.

FRANCO, Marcelo Araújo. A articulação entre técnica e semiótica na concretização do ambiente virtual. Contrapontos, Itajaí, v. 3, n. 2, maio/ago. 2003.

FRANZOI, Naira Lisboa. O conhecimento informal dos trabalhadores no chão de fábrica. Educação UNISINOS, São Leopoldo, v. 13, n. 3, set./dez. 2009.

FREIRE, Ana Maria Araújo. Educação para a paz segundo Paulo Freire. Educação (PUCRS), Porto Alegre, v. 29, n. 2, 2006.

FREIRE, Ida Mara. Dança-educação: o corpo e o movimento no espaço do conhecimento. Cadernos CEDES, Campinas, v. 21, n. 53, abr. 2001.

FRIAS, Ana; TEIXEIRA, Filomena. Campanhas de prevenção da infecção VIH/SIDA: analisando modos de educar a sexualidade e o género. Revista Ibero-Americana de Estudos em Educação, v. 8, n. 4, out./dez. 2013.

FRIGOTTO, Gaudêncio. Educação e qualificação de jovens e adultos pouco escolarizados: promessa integradora num tempo histórico de produção destrutiva. Perspectiva, Florianópolis, v. 31, n. 2, maio/ago. 2013.

FRÓIS, João Pedro. As ideias nascem do real: ensaio sobre museus de arte. Educação (PUCRS), Porto Alegre, v. 34, n. 3, 2011.

FUENTES, Sebastian. La formación moral de los jóvenes de elite en circuitos de educación privada en Buenos Aires. Pro-Posições, Campinas, v. 26, n. 2, maio/ago. 2015.

FUHRMANN, Nadia; PAULO, Fernanda dos Santos. A formação de educadores na educação não formal pública. Educação \& Sociedade, Campinas, v. 35, n. 127, abr./jun. 2014.

FUSARI, Andrea. As crianças e os direitos de cidadania: a cidade como comunidade educadora. Educação \& Sociedade, Campinas, v. 23, n. 78, abr. 2002.

GADOTTI, Moacir. A Ecopedagogia como pedagogia apropriada ao processo da Carta da Terra. Revista de Educação Pública, Cuiabá, v. 12, n. 21, jan/jun. 2003.

Educação para o desenvolvimento sustentável: o que precisamos aprender para salvar o planeta. Revista da FAEEBA, Salvador, n. 28, jul./dez. 2007. 
GALLEGO, Domingo J. Pais e estilos de aprendizagem de seus filhos. Revista Diálogo Educacional, Curitiba, v. 7, n. 20, jan./abr. 2007.

GALVANI, Mara Aparecida Magero. Leitura da imagem: uma interação de olhares entre cidade e escola. Educação \& Realidade, Porto Alegre, v. 30, n. 2, jul./dez. 2005.

GARCIA, Dolores Ap.; SATO, Michèle. Mitos e lendas na identidade cultural pantaneira: subsídios à educação ambiental. Revista de Educação Pública, Cuiabá, v. 15, n. 29, set./dez. 2006.

GARCIA, Maria Alice Amorim. Saber, agir e educar: o ensino-aprendizagem em serviços de saúde. Revista de Educação PUC-Campinas, Campinas, n. 9, dez. 2000.

GARCIA, Pedro Benjamim; FARIAS, Hamilton. Educação e cultura popular: um estado da arte de 1999 a 2006. E-Curriculum, São Paulo, v. 7, n. 3, dez. 2009.

GARCIA, Valéria Aroeira. A publicização e a legitimação da educação não formal. Revista de Educação PUC-Campinas, Campinas, n. 27, jul./dez. 2009.

GARRÉ, Bárbara Hees; HENNING, Paula Corrêa. Modos de atualizar o enunciado catastrófico do Planeta Terra na revista Veja. Educação Temática Digital, Campinas, v. 16, n. 3, set./dez. 2014.

GAUTHIER, Jacques Zanidê; CASTRO JÚNIOR, Luís Vítor; BATISTA, Maria Geovanda. Educação popular no auê e na capoeira: rodas e resistências sociopoéticas na Bahia. Revista de Educação Pública, Cuiabá, v. 12, n. 22, jul./dez. 2003.

GAZZINELLI, Maria Flávia Carvalho et al. Percepção e gestão ambiental: de espaços indiferenciados para lugares valorizados. Educação em Revista, Belo Horizonte, n. 36, dez. 2002.

GEE, Elisabeth. O game The Sims como catalisador da aprendizagem tecnológica de meninas. Perspectiva, Florianópolis, v. 33, n. 3, set./dez. 2015.

GENTIL, Heloisa Salles. O avesso e o direito: sobre sentidos e autoria em ambientes virtuais. Cadernos de Educação, Pelotas, n. 32, jan./abr. 2009.

GERHARDT, Heinz Peter. Redução temática: instrumento útil para o trabalho pedagógico. E-Curriculum, São Paulo, v. 11, n. 3, set./dez. 2013.

GHANEM, Elie. As ONGs e a responsabilidade governamental com a escola básica no Brasil. Pro-Posições, Campinas, v. 23, n. 2, maio/ago. 2012.

Inovação em educação ambiental na cidade e na floresta: o caso Oela. Cadernos de Pesquisa, São Paulo, v. 43, n. 150, set./dez. 2013.

GHIGGI, Gomercindo. Paulo Freire e a revivificação da Educação Popular. Educação (PUCRS), Porto Alegre, v. 33, n. 2, 2010.

GHIGGI, Gomercindo; CUNHA, Aline Lemos da. Ensaios sobre educação popular: retomando reflexões através de Freire. Contrapontos, Itajaí, v. 7, n. 3, set./dez. 2007.

GHIGGI, Gomercindo; KAVAYA, Martinho. Otchiwo, Ondjango e Círculos de Cultura: das práticas de resistência à constituição da educação libertadora - diálogos Angola/Brasil. Currículo sem Fronteiras, v. 12, n. 2, maio./ago. 2012. 
GIGLIO, Zula Garcia. A criatividade, o eu e a educação não formal: os frutos da parceria. Linhas Críticas, Brasília, v. 8, n. 15, jul./dez. 2002.

GIOVANETTI, Maria Amélia G. Tendência e perspectivas do conhecimento no campo da EJA. Educação em Revista, Belo Horizonte, n. 32, dez. 2000.

GIOVANETTI, Maria Amélia G.; COSTA, Maria da Conceição M. G. L. da. Movimento sociais e educação: as lutas populares por educação em, Belo Horizonte nos anos 70 e 80 . Educação em Revista, Belo Horizonte, n. 26, dez. 1997.

GOHN, Maria da Glória. Educação popular na América Latina no novo milênio: impactos do novo paradigma. Educação Temática Digital, Campinas, v. 4, n. 1, 2002a.

Educação popular na América latina no novo milênio: impactos do novo paradigma.

Revista de Educação Pública, Cuiabá, v. 11, n. 19, jan./jul. 2002 b.

Movimentos sociais na contemporaneidade. Revista Brasileira de Educação, Rio de Janeiro, v. 16, n. 47, maio/ago. 2011.

GOMES, Ana Maria R.; FARIA, Eliene Lopes. Etnografia e aprendizagem na prática: explorando caminhos a partir do futebol no Brasil. Educação e Pesquisa, São Paulo, v. 41, n. especial, dez. 2015.

GÓMEZ, José Antonio Caride. Elogio de la pedagogía social: acerca de los nuevos y viejos desafíos de la educación social. Revista de Educação Pública, Cuiabá, v. 18, n. 38, set./dez. 2009.

GÓMEZ, José Ignacio Aguaded. A edu-comunicação: uma necessidade sentida, uma aposta urgente. Linhas Críticas, Brasília, v. 13, n. 24, jan./jun. 2007.

GONÇALVES, Maria Ilse Rodrigues. Mudanças nos sistemas de ensino: Teorias da aprendizagem que podem fundamentar a comunidade cooperativa de aprendizagem em rede. Linhas Críticas, Brasília, v. 10, n. 19, jul./dez. 2004.

GONDRA, José Gonçalves. Homo hygienicus: educação, higiene e a reinvenção do homem. Cadernos CEDES, Campinas, v. 23, n. 59, abr. 2003.

GONZÁLEZ-GAUDIANO, Edgar. Um desafio inexorável à educação: mudança climática. Revista de Educação Pública, Cuiabá, v. 19, n. 41, set./dez. 2010.

GONZÁLEZ-GAUDIANO, Edgar; LORENZETTI, Leonir. Investigação em educação ambiental na América Latina: mapeando tendências. Educação em Revista, Belo Horizonte, v. 25, n. 3, dez. 2009.

GONZALEZ, Wania; PEDROZA, Sâmia. Limites e possibilidades da atuação do pedagogo em espaços não formais de ensino: algumas questões para o debate. Educação e Cultura Contemporânea, Rio de Janeiro, v. 11, n. 26, 2014.

GORINI, Maria Isabel Pinto Coelho. Testemunhos de adultos com câncer: um redirecionamento à educação para a saúde. Educação (PUCRS), Porto Alegre, ano XXIV, n. 45, 2001.

GOULARTI FILHO, Alcides; RABELO, Giani. "Compaixão pela messe!": filhas do divino zelo e as pedagogias missionárias em ação na Vila Operária Mineração de Içara (SC-Brasil) 1959 a 1968. Educação em Foco (UFJF), Juiz de Fora, v. 20, n. 3, nov. 2015/fev. 2016. 
GRILLO, Sheila Vieira de Camargo; DOBRANSZKY, Enid Abreu; LAPLANE, Adriana Lia Friszman. Mídia impressa e educação científica: uma análise das marcas do funcionamento discursivo em três publicações. Cadernos CEDES, Campinas, v. 24, n. 63, maio/ago. 2004.

GUARÁ, Isa Maria F. R. Educação e desenvolvimento integral: articulando saberes na escola e além da escola. Em Aberto, Brasília, v. 21, n. 80, abr. 2009.

GUEDES-PINTO, Ana Lúcia; FONTANA, Roseli Aparecida Cação. As mulheres professoras, as meninas leitoras e o menino leitor: a iniciação no universo da escrita no patriarcalismo rural brasileiro. Uma leitura a partir de Infância de Graciliano Ramos. Cadernos CEDES, Campinas, v. 24, n. 63, maio/ago. 2004.

GUERRA, Antonio Fernando S. Atividades em educação ambiental. Contrapontos, Itajaí, v. 3, n. 1, jan./abr. 2003.

GUIMARÃES, Leandro Belinaso. Educação ambiental e literatura: narrativas sobre as florestas. Cadernos de Educação, Pelotas, n. 34, set./dez. 2009.

GUIMARÃES, Leandro Belinaso; PEREIRA, Juliana Cristina. Os ambientes da imagem: pedagogias em foco. Educação (PUCRS), Porto Alegre, v. 38, n. 1, 2015.

GUIMARÃES, Leandro Belinaso; SAMPAIO, Shaula Maíra Vicentini de. Educação ambiental nas pedagogias do presente. Em Aberto, Brasília, v. 27, n. 91, jan./jun. 2014.

GUIMARÃES, Maria Tereza. Organização camponesa em Goiás nas décadas de 1950-1960 e os sinais de novas práticas educativas nos atuais movimentos sociais. Inter-Ação, Goiânia, v. 29, n. 2, jul./dez. 2004.

GUIMARÃES, Mauro; VASCONCELLOS, Maria das Mercês N. Relações entre educação ambiental e educação em ciências na complementaridade dos espaços formais e não formais de educação. Educar em Revista, Curitiba, n. 27, jan./jun. 2006.

HADDAD, Sérgio. Balanço da produção de conhecimentos sobre educação não escolar de adultos: educação e desenvolvimento. E-Curriculum, São Paulo, v. 7, n. 3, dez. 2009.

Paulo Freire e o papel das agências de cooperação europeias no apoio à educação popular no Brasil. Pro-Posições, Campinas, v. 25, n. 3 set./dez. 2014.

HÄDRICH, Wanise Rilho; RUSCHEINSKY, Aloísio. Educação ambiental para a qualidade de vida: suas conexões com o social, a estética e a saúde. Revista de Educação Pública, Cuiabá, v. 16, n. 30, jan./abr. 2007.

HAGE, Salomão Mufarrej; OLIVEIRA, Lorena Maria Mourão de. Território, políticas públicas e educação do campo na Amazônia paraense: o protagonismo dos movimentos sociais em debate. Revista de Educação Pública, Cuiabá, v. 20, n. 42, jan./abr. 2011.

HALMANN, Adriane Lizbehd. Diários (eletrônicos) de professores: histórias que se cruzam na sociedade aprendente. Revista da FAEEBA, Salvador, n. 22, jul./dez, 2004.

HAMANN, Edgar Merchán. O sociodrama pedagógico e a educação em saúde: possibilidades de diálogo compartilhamento de saberes e práticas. Linhas Críticas, Brasília, v. 4, n. 7-8, jul./jun. 1999.

HAMILTON, David. O revivescimento da aprendizagem?. Educação \& Sociedade, Campinas, v. 23, n. 78, abr. 2002. 
HARASIM, Linda. Educação online e as implicações da inteligência artificial. Revista da FAEEBA, Salvador, v. 24, n. 44, jul./dez. 2015.

HART, Paul. Em resposta a "Isto não é bom o suficiente": reflexões sobre a pesquisa em educação ambiental no Canadá em contextos de expansão. Educação em Revista, Belo Horizonte, v. 25, n. 3, dez. 2009.

HATZENBERGER, Dulce Helena Cabral. Desemprego: impacto e aprendizagens. Educação (PUCRS), Porto Alegre, ano XXV, n. 46, 2002.

HENNING, Paula Corrêa et al. Educação ambiental e discurso: estratégias biopolíticas e produção de verdades. Educação em Foco (UFJF), Juiz de Fora, v. 19, n. 1, mar./jun. 2014.

HENTSCHKE, Liane et al. Motivação para aprender música em espaços escolares e nãoescolares. Educação Temática Digital, Campinas, v. 10, número especial, 2009.

HERDT, Samyra Orben; MARCOMIN, Fátima Elizabeti. Perscrutando o educador de cada um: uma vivência à luz da percepção de agricultores agroecológicos. Revista de Educação Pública, Cuiabá, v. 24, n. 57, set./dez. 2015.

HEROLD JUNIOR, Carlos. A educação corporal no Paraná através do movimento escoteiro em Guarapuava (1927-1936). Educação em Revista, Belo Horizonte, v. 27, n. 2, ago. 2011.

HIGUCHI, Maria Inês Gasparetto; ALVES, Heloisa Helena Stopatto Cruz; SACRAMENTO, Luiza Conceição. A arte no processo educativo de cuidado pessoal e ambiental. Currículo sem Fronteiras, v. 9, n. 1, jan./jun. 2009.

HOFMANN, Angela Ariadne. "A leitura do mundo precede a leitura da palavra": Paulo Freire e educação indígena. Revista da FAEEBA, Salvador, n. 21, jan./jun, 2004.

HÜRING, Simone Maria. A cidade precisa dormir em paz. Relações entre educação, psicologia e risco social. Cadernos de Educação, Pelotas, n. 32, jan./abr. 2009.

IRELAND, Timothy D. Educação em prisões no Brasil: direito, contradições e desafios. Em Aberto, Brasília, v. 24, n. 86, nov. 2011.

IRELAND, Timothy D.; LUCENA, Helen Halinne Rodrigues de. O presídio feminino como espaço de aprendizagens. Educação \& Realidade, Porto Alegre, v. 38, n. 1, jan./mar. 2013.

JACOBI, Pedro. Educação ambiental, cidadania e sustentabilidade. Cadernos de Pesquisa, São Paulo, n. 118, mar. 2003.

JACOBI, Pedro Roberto; TRISTÃO, Martha; FRANCO, Maria Isabel Gonçalves Correa. A função social da educação ambiental nas práticas colaborativas: participação e engajamento. Cadernos CEDES, Campinas, v. 29, n. 77, jan./abr. 2009.

JAMBEIRO, Othon et al. A televisão no Brasil e a Regulamentação de suas Finalidades Educativas e Culturais. Revista da FAEEBA, Salvador, n. 6, jul./dez. 1996.

JESUS, Suzana Cavalheiro de. Brincadeiras de crianças Mbyá-Guarani no urbano: reflexões acerca da antropologia e da psicologia da educação. Educação (UFSM), Santa Maria, v. 35, n. 1, jan./abr. 2010.

JIMÉNEZ, César Muñoz. Entrevista com César Muñoz Jiménez: A aprendizagem presente na convivência: um encontro entre a educação integral e a pedagogia da vida cotidiana. Educação em Revista, Belo Horizonte, v. 31, n. 4, out./dez. 2015. 
JIMENEZ, Susana; TERCEIRO, Emanoela. A crise ambiental e o papel da educação: um estudo fundado na ontologia marxiana. Educação em Revista, Belo Horizonte, v. 25, n. 3, dez. 2009.

JULIÃO, Elionaldo Fernandes. O impacto da educação e do trabalho como programas de reinserção social na política de execução penal do Rio de Janeiro. Revista Brasileira de Educação, Rio de Janeiro, v. 15, n. 45, set./dez. 2010.

JULIÃO, Elionaldo Fernandes; PAIVA, Jane. A leitura no espaço carcerário. Perspectiva, Florianópolis, v. 32, n. 1, jan./abr. 2014.

JUNGHAUS, José Mauro. Sustentabilidade: desenvolvimento econômico sustentável e educação ambiental. Contrapontos, Itajaí, v. 3, n. 1, jan./abr. 2003.

JUNQUEIRA, Sérgio R. Ecoeducação: um desafio permanente. Revista Diálogo Educacional, Curitiba, v. 1, n. 2, jul./dez. 2000.

KALINOVSKI, Érica Fernanda; FRANÇA, Fabiane Freire. A construção de narrativas históricas: conservação da memória na terceira idade. Revista Ibero-Americana de Estudos em Educação, v. 10, n. 3, jul./set. 2015.

KALMAN, Judith. A study of community as a space for reading and writing. Revista Brasileira de Educação, Rio de Janeiro, n. 26, maio/ago. 2004.

KAPLAN, Leonardo; LOUREIRO, Carlos Frederico Bernardo. Análise crítica do discurso do Programa Nacional de Formação de Educadoras(es) Ambientais - PROFEA: pela não desescolarização da educação ambiental. Educação em Revista, Belo Horizonte, v. 27, n. 2, ago. 2011.

KLEIN, Carin. Educação de mulheres-mães pobres para uma "infância melhor". Revista Brasileira de Educação, Rio de Janeiro, v. 17, n. 51, set./dez. 2012.

KLEIN, Carin; MEYER, Dagmar Estermann; BORGES, Zulmira Newlands. Políticas de inclusão social no Brasil contemporâneo e educação da maternidade. Cadernos de Pesquisa, São Paulo, v. 43, n. 150, set./dez. 2013.

KNIJNIK, Gelsa. Currículo, etnomatemática e educação popular: um estudo em um assentamento do movimento sem terra. Currículo sem Fronteiras, v. 3, n. 1, jan./jun. 2003.

KUHLMANN Jr., Moysés; FERNANDES, Fabiana Silva. Educação, cultura e infância no Parque Infantil Paulistano (1947-1957). Revista Diálogo Educacional, Curitiba, v. 14, n. 43, set./dez. 2014.

KULESZA, Wojciech Andrzej. Reforma agrária e educação. Revista Brasileira de Estudos Pedagógicos, Brasília, v. 89, n. 222, maio/ago. 2008.

KUNRATH, Leticia Hoffman. Reflexões acerca das estratégias educativas nas famílias com crianças com TDA/H. Cadernos de Educação, Pelotas, n. 32, jan./abr. 2009.

KUNREUTHER, Flavio Theodor; FERRAZ, Osvaldo Luiz. Educação ao ar livre pela aventura: o aprendizado de valores morais em expedições à natureza. Educação e Pesquisa, São Paulo, v. 38, n. 2, abr./jun. 2012.

LAGE, Allene Carvalho. A pedagogia que emerge da luta política do MST. Revista de Educação Pública, Cuiabá, v. 17, n. 35, set./dez. 2008. 
LAJONQUIÈRE, Leandro de. Sigmund Freud: para uma educação além da pedagogia. Educação Temática Digital, Campinas, v. 8, n. esp, 2006.

LAMÔNICA, Adilea B. De. Araés: espaço, cultura, identidade étnica e educação. Revista de Educação Pública, Cuiabá, v. 5, n. 7, jan./jun. 1996.

LANDINI, Sonia Regina. Educação popular: os muitos desafios. Educação (UFSM), Santa Maria, v. 36, n. 3, set./dez. 2011.

LARANJEIRA, Denise Helena P.; TEIXEIRA, Ana Maria Freitas. Vida de jovens: educação não-formal e inserção socioprofissional no subúrbio. Revista Brasileira de Educação, Rio de Janeiro, v. 13, n. 37, jan./abr. 2008.

LAROQUE, Luís Fernando da Silva; SILVA, Juciane Beatriz Sehn da. Ambiente e cultura Kaingang: saúde e educação na pauta das lutas e conquistas dos Kaingang de uma terra indígena. Educação em Revista, Belo Horizonte, v. 29, n. 2, jun. 2013.

LAZARO, André; TELES, Jorge. Educação não formal no Brasil: um olhar pósCONFINTEA VI. Teias, Rio de Janeiro, v. 15, n. 35, jan./mar. 2014.

LEÃO, Geraldo Magela Pereira. Educar, ocupar, vigiar: alcances e limites de um programa para jovens pobres. Perspectiva, Florianópolis, v. 26, n. 1, jan./jun. 2008.

LEÃO, Geraldo Magela Pereira; CARRANO, Paulo César Rodrigues. O jovem Milton: a individuação entre a igreja e a educação social. Educação \& Realidade, Porto Alegre, v. 38, n. 3, jul./set. 2013.

LEIRO, Augusto Cesar Rios; MORAES, Cândida Andrade de; SANTOS, Vanessa Ribeiro dos. Educação popular e pedagogia social: diálogo singular e experiência plural. Revista da FAEEBA, Salvador, v. 24, n. 43, jan./jun. 2015.

LEITÃO, Cleide Figueiredo. Buscando caminhos nos processos de formação/autoformação. Revista Brasileira de Educação, Rio de Janeiro, n. 27, set./dez. 2004.

LEITE, Lúcia Helena Alvarez. Educação integral, territórios educativos e cidadania: aprendendo com as experiências de ampliação da jornada escolar em, Belo Horizonte e Santarém. Educar em Revista, Curitiba, n. 45, jul./set. 2012.

LEITE, Maria Isabel. O serviço educativo dos museus e o espaço imaginativo das crianças. Pro-Posições, Campinas, v. 15, n. 1, 2004.

LERIPIO, Alexandre de Ávila; CAMPOS, Lucila Maria de Souza; SELIG, Paulo Mauricio. O papel da percepção na educação e desempenho ambiental das organizações: uma discussão sobre o tema. Contrapontos, Itajaí, v. 3, n. 1, jan./abr. 2003.

LEROUX, Liliane; MARTINEZ, Ana Beatriz Campuzano. “É aula ou filme, professora?" cenas de um cineclube na escola prisional. Educação e Cultura Contemporânea, Rio de Janeiro, v. 12, n. 29, 2015.

LIBÂNEO, José Carlos. Pedagogia e pedagogos: inquietações e buscas. Educar em Revista, Curitiba, n. 17, jan./jun. 2001.

LIMA, Ivan Costa. Trajetória, história e identidade negra: elementos de constituição da pedagogia interétnica em, Salvador. Teias, Rio de Janeiro, v. 9, n. 16-17, jan./jun. 2008. 
LIMA, José Antonio de Oliveira. Educação somática: limites e abrangências. Pro-Posições, Campinas, v. 21, n. 2, 2010.

LIMA, Lucia Ceccato de. Modelo aberto de educação ambiental. Educação Temática Digital, Campinas, v. 15, n. 1, jan./abr. 2013.

LIMA, Lysne Nôzenir Camelo de. A pedagogia no combate ao trabalho infantil no município de Boa Vista. Revista Ibero-Americana de Estudos em Educação, v. 7, n. 4, out./dez. 2012.

LIMA, Márcio Roberto de. Educação na cibercultura: novas possibilidades para o ensinoaprendizagem. Educação e Cultura Contemporânea, Rio de Janeiro, v. 8, n. 16, jan./jun. 2011.

LLAVADOR, Francisco Beltrán. Educar: un concurrir apasionado a la ciudad. Pro-Posições, Campinas, v. 18, n. 1, 2007.

LONGARAY, Deise Azevedo; RIBEIRO, Paula Regina Costa. Espaços educativos e produção das subjetividades gays, travestis e transexuais. Revista Brasileira de Educação, Rio de Janeiro, v. 20, n. 62, jul./set. 2015.

LOPES, Doraci Alves. Educação não formal e avaliação: em busca de um debate. ECurriculum, São Paulo, v. 10, n. 3, dez. 2012.

LOPES, Eliane Marta Teixeira. Relações coloniais como relações educativas. Revista Brasileira de Educação, Rio de Janeiro, n. 15, set./dez. 2000.

LOPES, José de Sousa Miguel. Educação e cinema: contestando a hegemonia hollywoodiana. Educação em Revista, Belo Horizonte, n. 41, jun. 2005.

LOUREIRO, Armando. As organizações não-governamentais de desenvolvimento local e a sua prática educativa de adultos: uma análise no norte de Portugal. Revista Brasileira de Educação, Rio de Janeiro, v. 13, n. 38, maio/ago. 2008.

Um centro de educação e formação de adultos que aprende. Educação em Revista, Belo Horizonte, v. 26, n. 2, ago. 2010.

LOUREIRO, Carlos Frederico Bernardo. Emancipação e complexidade: para o repensar das tendências em educação ambiental. Cadernos de Educação, Pelotas, n. 25, jul./dez. 2005.

LOUREIRO, Carlos Frederico Bernardo; COSTA, Samira Lima da. Educação ambiental, corpo e sociedade: tecendo relações. Educação em Revista, Belo Horizonte, n. 38, dez. 2003.

LOUREIRO, Carlos Frederico Bernardo; SAISSE, Maryane. Educação ambiental na gestão ambiental pública brasileira: uma análise da SEMA ao ICMBio. Revista de Educação Pública, Cuiabá, v. 23, n. 52, jan./abr. 2014.

LOZANO, Javier Orlando. El voluntariado educativo en contextos de diversidad étnica y cultural. Cadernos de Educação, Pelotas, n. 43, set./dez. 2012.

LYRA, Jorge et al. "A gente não pode fazer nada, só podemos decidir sabor de sorvete". Adolescentes: de sujeito de necessidades a um sujeito de direitos. Cadernos CEDES, Campinas, v. 22, n. 57, ago. 2002. 
MACEDO FILHO, Francisco Dutra de; CABRAL NETO, Antônio. A educação ambiental no cenário da economia informacional globalizada. Educação em Questão, Natal, v. 29, n. 15, maio/ago. 2007.

MACHADO, Aline Maria Batista. A relevância da educação popular para o serviço social. Educação UNISINOS, São Leopoldo, v. 17, n. 2 maio./ago. 2013.

MACHADO, Charliton José dos Santos; VASCONCELOS, Larissa Meira de. Higienismo, imprensa e educação na Parahyba do Norte: o papel da mulher e a pedagogização dos hábitos. Educação em Foco (UFJF), Juiz de Fora, v. 20, n. 3, nov./fev. 2015.

MACHADO, Rejane Ramos. Percepções e práticas dos atores em comunidades virtuais. Educação Temática Digital, Campinas, v. 14, n. 2, jul./dez. 2012.

MACUCH, Regiane. Ampliando o espaço e o tempo da sala de aula. Revista Diálogo Educacional, Curitiba, v. 5, n. 15, maio/ago. 2005.

MAEYER, Marc de. Ter tempo não basta para que alguém se decida a aprender. Em Aberto, Brasília, v. 24, n. 86, nov. 2011.

A educação na prisão não é uma mera atividade. Educação \& Realidade, Porto Alegre, v. 38, n. 1, jan./mar. 2013.

MAGALHÃES, Hilda Gomes Dutra. Ecopedagogia e utopia. Educação Temática Digital, Campinas, v. 7, n. 1, 2005.

MAGALHÃES, Justino. As cidades e a educação em Portugal. Educação UNISINOS, São Leopoldo, v. 5, n. 9, jul./dez. 2001.

MAGALHÃES, Luiz Marconi Fortes. Educação ambiental e sociedades sustentáveis: um saber-fazer para as pessoas viventes no mundo contemporâneo. Revista da FAEEBA, Salvador, n. 28, jul./dez. 2007.

MAGRO, Viviane Melo de Mendonça. Adolescentes como autores de si próprios: cotidiano, educação e o hip hop. Cadernos CEDES, Campinas, v. 22, n. 57, ago. 2002.

MAIA, Ana Cláudia Bortolozzi et al. Educação sexual para pessoas com deficiência física. Revista Ibero-Americana de Estudos em Educação, v. 10, n. 1, jan./mar. 2015.

MALFITANO, Ana Paula Serrata; LOPES, Roseli Esquerdo. Educação popular, ações em saúde, demandas e intervenções sociais: o papel dos agentes comunitários de saúde. Cadernos CEDES, Campinas, v. 29, n. 79, set./dez. 2009.

MANKE, Lisiane Sias. Leitores rurais: apropriação ético-prática nos sentidos atribuídos à leitura. Revista Brasileira de Educação, Rio de Janeiro, v. 20, n. 63, out./dez. 2015.

MANTOVANI, Ana Margô; BACKES, Luciana; SANTOS, Bettina Steren dos. Formação do educador no contexto da cibercultura: possibilidades pedagógicas em metaversos (mundos digitais virtuais em 3 dimensões - MDV3D). Contrapontos, Itajaí, v. 12, n. 1, jan./abr. 2012.

MARANDINO, Martha. Transposição ou recontextualização? Sobre a produção de saberes na educação em museus de ciências. Revista Brasileira de Educação, Rio de Janeiro, n. 26, maio/ago. 2004. 
Análise sociológica da didática museal: os sujeitos pedagógicos e a dinâmica de constituição do discurso expositivo. Educação e Pesquisa, São Paulo, v. 41, n. 3, jul./set. 2015.

MARCELlO, Fabiana de Amorim. Dispositivo da maternidade: mídia e a produção pedagógica de sujeitos, práticas e normas. Educar em Revista, Curitiba, n. 26, jul./dez. 2005.

MARCON, Telmo. Os movimentos sociais populares como educadores: contribuições teóricas e políticas. Educação (UFSM), Santa Maria, v. 37, n. 3, set./dez. 2012.

MARÍN-DÍAZ, Dora Lilia. La clave es el individuo: prácticas de sí y aprendizaje permanente. Educação UNISINOS, São Leopoldo, v. 19, n. 2, maio/ago. 2015.

MARIN, Andreia Aparecida. A educação ambiental nos caminhos da sensibilidade estética. Inter-Ação, Goiânia, v. 31, n. 2, jul./dez. 2006.

Ética, estética e educação ambiental. Revista de Educação PUC-Campinas, Campinas, n. 22, jun. 2007.

MARIN, Andréia Aparecida; KASPER, Kátia Maria. A natureza e o lugar habitado como âmbitos da experiência estética: novos entendimentos da relação ser humano - ambiente. Educação em Revista, Belo Horizonte, v. 25, n. 2, ago. 2009.

MARINIS, Pablo de. Comunidade, globalização e educação: um ensaio sobre a desconversão do social. Pro-Posições, Campinas, v. 19, n. 3, 2008.

MARQUES, Marcelo; ALVES, Natália. O Programa Novas Oportunidades numa agenda globalmente estruturada para a educação. Perspectiva, Florianópolis, v. 31, n. 2, maio/ago. 2013.

MARTÍNEZ, Pedro L. Moreno. A educação do corpo fora da escola: as origens das colônias de férias na Espanha. Educar em Revista, Curitiba, n. 33, jan./abr. 2009.

La historiografía del patrimonio educativo en España: un balance crítico. Educar em Revista, Curitiba, n. 58, out./dez. 2015.

MARTINS, Daniela Maria Barreto. Identidade-diferença, novas TICS e a cultura dos grupos: os contextos intersticiais como agentes de transformação. Revista da FAEEBA, Salvador, n. 22, jul./dez, 2004.

MARTINS, Ernesto Candeias. Educar adultos maiores na área da educação social: a intergeracionalidade numa sociedade para todas as idades. Inter-Ação, Goiânia, v. 40, n. 3, set./dez. 2015.

MARTINS, Francisco André Silva; DAYRELL, Juarez Tarcísio. Juventude e participação: o grêmio estudantil como espaço educativo. Educação \& Realidade, Porto Alegre, v. 38, n. 4, out./dez. 2013.

MARTINS, Mirian Celeste. Acolhimento estético: mediação para públicos especiais na mostra do redescobrimento em, São Paulo. Revista de Educação PUC-Campinas, Campinas, n. 11, nov. 2001.

Arte, só na aula de arte?. Educação (PUCRS), Porto Alegre, v. 34, n. 3, 2011. 
MARTINS, Mirian Teresa. Práticas educativas: projetos e programas de educação sexual. Teias, Rio de Janeiro, v. 12, n. 24, jan./abr. 2011.

MARTINS, Suely. Movimentos sociais e educação do campo: a experiência dos jovens do MST no Paraná. Educação em Foco (UFJF), Juiz de Fora, v. 18, n. 1, mar./jun. 2013.

MARTINS, Valter. Policiais e populares: educadores, educandos e a higiene social. Cadernos CEDES, Campinas, v. 23, n. 59, abr. 2003.

MASCARELLO, Andrea Stefania; OMETTO, Cláudia Beatriz de Castro Nascimento. O convite de Hannah Arendt: (re)significações da crise na educação. Educação UNISINOS, São Leopoldo, v. 19, n. 2, maio/ago. 2015.

MATAREZI, José. Despertando os sentidos da educação ambiental. Educar em Revista, Curitiba, n. 27, jan./jun. 2006.

MATOS, Elizete Lúcia Moreira; FIALHO, Francisco Antonio Pereira. Tecnologias além do virtual. Revista Diálogo Educacional, Curitiba, v. 4, n. 13, set./nov. 2004.

MATOS, Gláucio Campos Gomes de. Entre rios e florestas: experiências de campo de um professor de educação física no ambiente rural amazônico. Em Aberto, Brasília, v. 26, n. 89, jan./jun. 2013.

MATTOZZI, Ivo. Il museo nel curricolo di storia: una questione di trasposizione didattica. Educar em Revista, Curitiba, n. 58, out./dez. 2015.

MEDEIROS, Heitor Queiroz de; SATO, Michèle. Temperos de Chico Mendes no cardápio da educação ambiental antropofágica. Revista de Educação Pública, Cuiabá, v. 15, n. 27, jan./abr. 2006.

MEDEIROS NETA, Olivia Morais. Pela cidade, educabilidades (Príncipe, Rio Grande do Norte - século XIX). Educar em Revista, Curitiba, n. 51, jan./mar. 2014.

MELLO, Marisol Barenco de. Crianças catadoras e seus saberes: quando o contexto é o lixo. Teias, Rio de Janeiro, v. 5, n. 8-9, jan./dez. 2004.

MELlO, Roseli Rodrigues de. Tertúlia Literária Dialógica: espaço de aprendizagem dialógico. Contrapontos, Itajaí, v. 3, n. 3, set./dez. 2003.

MELO, Adriana Magalhães Alves de. A criança que aprende divertindo-se e a tela que diverte educando: a recepção infantil de programas de TV lúdico-educativos ligados a educação ambiental. Linhas Críticas, Brasília v. 7, n. 13, jul./dez. 2001.

MELO, Alessandro de; CARDOZO, Poliana Fabiula. Patrimônio, turismo cultural e educação patrimonial. Educação \& Sociedade, Campinas, v. 36, n. 133, out./dez. 2015.

MELO, Marcelo Paula de. Relação lazer, escola e esporte nas políticas públicas de esporte na Cidade Maravilhosa. Pro-Posições, Campinas, v. 17, n. 3, 2006.

MELO, Maria de Fátima Aranha Queiroz e. Algumas aprendizagens construídas durante a brincadeira de pipa: o que está em jogo. Educação em Revista, Belo Horizonte, v. 26, n. 2, ago. 2010.

MENDONÇA, Sueli Guadelupe de Lima. A crise de sentidos e significados na escola: a contribuição do olhar sociológico. Cadernos CEDES, Campinas, v. 31, n. 85, dez. 2011. 
MENEZES, Ana Luisa Teixeira de. Educação mito-dança-rito: as razões dialógicas do conhecer Guarani. Currículo sem Fronteiras, v. 10, n. 1, jan./jun. 2010.

MENEZES, Izabel Dantas de. A cor do invisível: saberes nas experiências educativas organizadas pela Central das Associações das Comunidades de Fundo e Fecho de Pasto da Região de Senhor do Bonfim - Bahia. Revista da FAEEBA, Salvador, n. 34, jul./dez. 2010.

MESQUIDA, Peri. O diálogo de Illich e Freire em torno da educação para uma nova sociedade. Contrapontos, Itajaí, v. 7, n. 3, set./dez. 2007.

MEUNIER, Anik; SOULIER, Virginie. Qual a relação entre a cultura e o patrimônio? Uma parceria cultural no contexto museal com o meio escolar de aprendizagem de francês. Educar em Revista, Curitiba, n. 58, out./dez. 2015.

MIGNOT, Ana Chrystina Venancio. Exercício de intimidade: uma aproximação com a aprendizagem da escrita de si. Revista da FAEEBA, Salvador, n. 40, jul./dez. 2013.

MILAN, Giuseppe. Para uma pedagogia de comunidade: o educador social. Revista da FAEEBA, Salvador, n. 28, jul./dez. 2007.

MILLER, Jussara. O corpo presente: uma experiência sobre dança-educação. Educação Temática Digital, Campinas, v. 16, n. 1, jan./abr. 2014.

MINETTO, Maria de Fátima et al. Práticas educativas e estresse parental de pais de crianças pequenas com desenvolvimento típico e atípico. Educar em Revista, Curitiba, n. 43, jan./mar. 2012.

MIRANDA, Carlos Henrique Albuquerque. Ver filmes, dizer educação, olhar cultura. Revista de Educação PUC, Campinas, Campinas, v. 3, n. 5, nov. 1998.

Uma educação do olho: as imagens na sociedade urbana, industrial e de mercado. Cadernos CEDES, Campinas, v. 21, n. 54, ago. 2001.

MIRANDA, Carlos Eduardo Albuquerque; RIGOTTI, Gabriela Fiorin; BEZERRA, Carolina Cavalcanti. O papel da educação visual e da iconologia na exaltação dos valores nacionais e na inclusão ou rejeição do estrangeiro. Cadernos de Educação, Pelotas, n. 33, maio/ago. 2009.

MITTER, Wolfgang. A educação no processo de globalização: algumas considerações sobre um debate atual e controverso. Em Aberto, Brasília, v. 19, n. 75, jul. 2002.

MOLL, Jaqueline; FISCHER, Nilton Bueno. Educação, trabalho e renda: a UFRGS e as ações com jovens e adultos. Educação em Revista, Belo Horizonte, n. 32, dez. 2000.

MÔNACO, Graziela Del; JANKE, Nadja; ALMEIDA, Isadora Puntel de. O processo grupal na pesquisa em educação ambiental: reflexões compartilhadas. Contrapontos, Itajaí, v. 5, n. 1, jan./abr. 2005.

MONTEIRO, Marco Aurélio Alvarenga et al. O papel do ensino informal de ciências: uma análise sobre o impacto do show de energia sobre o interesse dos alunos para cursos de áreas de ciências exatas. Revista Ibero-Americana de Estudos em Educação, v. 7, n. 2, abr./jun. 2012. 
MORAES, Ana Shirley de França. Educação permanente: a saída para o trabalhador na era da qualidade total. Educação Brasileira de Estudos Pedagógicos, Brasília, v. 77, n. 185. 1996.

MORAES, José Damiro de. A educação libertária na bagagem dos imigrantes: uma trajetória no brasil. Revista de Educação PUC-Campinas, Campinas, n. 8, jun. 2000.

MORAES, Maria Stela Marcondes de. O Movimento dos Atingidos pelas Barragens da Bacia do Rio Uruguai e a ação político-educativa dos mediadores. Revista Brasileira de Educação, Rio de Janeiro, n. 1, jan./abr. 1996.

MOREIRA, Alex. O aprender como fator de mudança nas organizações. Educação em Foco (UEMG), Belo Horizonte, v. 12, n. 14, 2009.

MOREIRA, Janine et al. Educação popular em saúde: a educação libertadora mediando a promoção da saúde e o empoderamento. Contrapontos, Itajaí, v. 7, n. 3, set./dez. 2007.

MOREIRA, Janine et al. A educação permanente em saúde e sua relação com o empoderamento: reflexões a partir das agentes comunitárias de saúde. Teias, Rio de Janeiro, v. 14, n. 34, set./dez. 2013.

MORETO, Marina. A educação e a arte nos entrelugares da rua. Educação Temática Digital, Campinas, v. 12, n. 2, 2011.

MORGADO, Leonel. Os mundos virtuais e o ensino-aprendizagem de procedimentos. Educação e Cultura Contemporânea, Rio de Janeiro, v. 6, n. 13, jul./dez. 2009.

MORGADO, Maria Aparecida; SILVA, Jocenaide Maria Rossetto. As canções do Movimento dos Trabalhadores Rurais Sem Terra - MST: Educação, Identificação e Cultura. Revista de Educação Pública, Cuiabá, v. 9, n. 16, jul./dez. 2000.

MORROW, Raymond A.; TORRES, Carlos Alberto. Gramsci e a educação popular na América Latina - percepções do debate brasileiro. Currículo sem Fronteiras, v. 4, n. 2, jul./dez. 2004.

MOTA, Kátia Santos Mota. Aulas de português fora da escola: famílias imigrantes brasileiras, esforços de preservação da língua materna. Cadernos CEDES, Campinas, v. 24, n. 63, maio/ago. 2004.

MOURA, Denise A. Soares de. Café e educação no século XIX. Cadernos CEDES, Campinas, v. 20, n. 51, nov. 2000.

MOURA, Eliana; ZUCCHETTI, Dinora Tereza. Explorando outros cenários: educação não escolar e pedagogia social. Educação UNISINOS, São Leopoldo, v. 10, n. 3, set./dez. 2006.

Educação não escolar, universidades e educação popular: horizonte de novos desafios. Educação UNISINOS, São Leopoldo, v. 13, n. 2, maio/ago. 2009.

Educação além da escola: acolhida a outros saberes. Cadernos de Pesquisa, São Paulo, v. 40, n. 140, maio/ago. 2010.

Socialização escolar, educação não escolar e (con)formação de sujeitos. Contrapontos, Itajaí, v. 14, n. 2, maio/ago. 2014.

MÜHLENBERG, Liane Maria. Mobilização social e psicodrama no trabalho comunitário. Linhas Críticas, Brasília, v. 4, n. 7-8, jul./jun. 1999. 
MUNARIM, Antonio. Educação de jovens e adultos agricultores, um problema de política pública e cidadania. Perspectiva, Florianópolis, v. 19, n. 1, jan./jun. 2001.

MUÑOZ, Vernor. O direito à educação das pessoas privadas de liberdade. Em Aberto, Brasília, v. 24, n. 86, nov. 2011.

MUSSI, Luciana Helena; SILVEIRA, Nadia Dumara. Educação, envelhecimento e filmes de curta-metragem. E-Curriculum, São Paulo, v. 11, n. 1, abr. 2013.

MUTIM, Avelar Luiz Bastos. Educação ambiental e gestão de sociedades sustentáveis: análise da articulação de processos educativos formais e não formais como estratégia para a gestão do desenvolvimento local sustentável. Revista da FAEEBA, Salvador, n. 28, jul./dez. 2007.

NACHREINER JUNIOR, José. O jornalismo literário e o cinema como práticas de leitura nas universidades. Revista Diálogo Educacional, Curitiba, v. 5, n. 15, maio/ago. 2005.

NASCIMENTO, Antonio Dias; HETKOWSKI, Tânia Maria. Elos contemporâneos: possibilidades entre educação do campo e TIC. Revista da FAEEBA, Salvador, n. 30, jul./dez. 2008.

NASCIMENTO, Claudemiro Godoy do. A teoria crítica de Gramsci nas pedagogias alternativas de educação do campo. Linhas Críticas, Brasília, v. 13, n. 25, jul./dez. 2007.

NASCIMENTO, Denise da Silva Menezes do. A função pedagógica dos textos de Hadewijch. Acta Scientiarum. Education, Maringá, v. 33, n. 2, jul./dez. 2011.

NATIVIDADE, Lindinalvo. O discurso pedagógico na prática da capoeira. Teias, Rio de Janeiro, v. 12, n. 26, set./dez. 2011.

NEIVA, Luciana Franco de Oliveira. Lâminas disciplinares: a educação através do consumo. Teias, Rio de Janeiro, v. 9, n. 16-17, jan./jun. 2008.

NEVES, Barbará Coelho; COUTO, Edvaldo Souza. Convergência de recursos e mediação para inclusão digital: casos baianos. Educar em Revista, Curitiba, n. 46, out./dez. 2012.

NOFFS, Neide de Aquino; CARNEIRO, Maria Angela Barbato. A educação e a saúde: brinquedoteca hospitalar espaço de ressignificação para a criança internada. Revista IberoAmericana de Estudos em Educação, v. 5, n. 3, set./dez. 2010.

NOGUEIRA, Maria José; MODENA, Celina Maria; SCHALL, Virgínia Torres. Educação e saúde: descrevendo uma estratégia educativa propícia ao diálogo, reflexão e troca de experiências sobre sexualidade com adolescentes. Educação em Foco (UEMG), Belo Horizonte, v. 11, n. 11, 2008.

NOGUEIRA, Quefren Weld Cardozo. Esporte e a experiência de jogo como formação. Educação \& Realidade, Porto Alegre, v. 38, n. 3, jul./set. 2013.

NOVAES, Henrique T. A autogestão como magnífica escola: notas sobre a educação no trabalho associado. E-Curriculum, São Paulo, v. 7, n. 3, dez. 2009.

NOVAIS, Carlos Augusto; CARVALHO, Gilcinei Teodoro; MACHADO, Maria Zélia Versiani. Leituras de jovens de camadas populares: letramentos escolares e não escolares no campo. Revista da FAEEBA, Salvador, v. 24, n. 43, jan./jun. 2015. 
NOVICKI, Victor. Educação para o desenvolvimento sustentável ou sociedades sustentáveis?. Linhas Críticas, Brasília, v. 15, n. 29, jul./dez. 2009.

NUNES, Eduardo José Fernandes; SANTOS, Marcos César Guimarães dos; BARRETO, Maria Raidalva Nery. O observatório de educação de jovens e adultos e a educação popular no território do Sisal - Bahia. Revista da FAEEBA, Salvador, v. 24, n. 43, jan./jun. 2015.

OKADA, Alexandra Lilavati Pereira; SANTOS, Edméa Oliveira dos. Comunicação educativa no ciberespaço: utilizando interfaces gratuitas. Revista Diálogo Educacional, Curitiba, v. 4, n. 13, set./nov. 2004.

OLIVEIRA JÚNIOR, Samuel Borges de; SATO, Michèle. O saber local da cultura e da natureza nas narrativas biorregionais do Quilombo Mata Cavalo. Revista de Educação Pública, Cuiabá, v. 17, n. 35, set./dez. 2008.

OLIVEIRA, Ana Claudia Coelho de; SIQUEIRA, Vera Helena Ferraz de. O infame solitário: o que o documentário Solitário Anônimo pode acrescentar aos debates sobre educação em saúde?. Pro-Posições, Campinas, v. 24, n. 2, maio/ago. 2013.

OLIVEIRA, Anna Cynthia; HADDAD, Sérgio. As organizações da sociedade civil e as ONGs de educação. Cadernos de Pesquisa, São Paulo, n. 112, mar. 2001.

OLIVEIRA, Cecilia Helena de Salles. O Museu Paulista da USP e a memória da Independência. Cadernos CEDES, Campinas, v. 22, n. 58, dez. 2002.

OLIVEIRA, Clara Costa. Contributos educativos e comunitários Movimento Epistemológico da Auto-organização: um método auto-organizativo na formação de educadores de adultos. Educação (PUCRS), Porto Alegre, v. 30, n. 1, 2007.

OLIVEIRA, Inês Barbosa de. As interfaces educação popular e EJA: exigências de formação para a prática com esses grupos sociais. Educação (PUCRS), Porto Alegre, v. 33, n. 2, 2010.

OLIVEIRA, Jailton Alves de. Vadiagem, crime e civilização: a casa de detenção da Corte como espaço educativo (1880-1889). Teias, Rio de Janeiro, v. 13, n. 28, maio./ago. 2012.

OLIVEIRA, Maria Olivia de Matos; ORNELLAS, Maria de Lourdes Soares. Mídia e educação: interface processual na teoria das representações sociais. Revista da FAEEBA, Salvador, n. 42, jul./dez. 2014.

OLIVEIRA, Sandra Regina Ramalho et al. TV Escola no ensino da arte: uma pesquisa. Contrapontos, Itajaí, v. 2, n. 2, maio/ago. 2002.

ORMEZZANO, Graciela René; POMA, Silviani Teixeira. Educação socioambiental, imaginário e artes visuais. Educação (UFSM), Santa Maria, v. 38, n. 1, jan./abr. 2013.

ORTIZ, Leodi C. Meireles; FREITAS, Soraia Napoleão. Classe hospitalar: um olhar sobre sua práxis educacional. Revista Brasileira de Estudos Pedagógicos, Brasília, v. 82, n. 200/201/202, jan./dez. 2001.

ORTIZ, Leodi C. Meireles et al. A classe hospitalar como instrumento de participação política na construção coletiva da associação de pais e pacientes da hematooncologia. Educação em Revista, Belo Horizonte, v. 26, n. 2, ago. 2010.

OSORIO, Jorge Mario Flores. Pedagogía, solidaridad y transformación social. Educar em Revista, Curitiba, n. 53, jul./set. 2014. 
OVIGLI, Daniel Bovolenta. Panorama das pesquisas brasileiras sobre educação em museus de ciências. Revista Brasileira de Estudos Pedagógicos, Brasília, v. 96, n. 244, set./dez. 2015 .

PACHECO, Raquel da Veiga; MELO, Sonia Maria Martins de. A influência de filmes da Barbie sobre a educação sexual das crianças: na busca da compreensão de professoras sobre o tema. Revista Ibero-Americana de Estudos em Educação, v. 9, n. 3, jul./set. 2014.

PAIVA, Jane. Onde a luta ensina: olhos de aprendiz no movimento social. Teias, Rio de Janeiro, v. 3, n. 6, jul./dez. 2002.

Tramando concepções e sentidos para redizer o direito à educação de jovens e adultos. Revista Brasileira de Educação, Rio de Janeiro, v. 11, n. 33, set./dez. 2006.

PAIVA, Marlúcia. Sociedade, educação e religião: o caso da ação educativa da Arquidiocese de, Natal (1944-1964). Educação em Questão, Natal, v. 7, n. 1/2, jan./dez. 1997.

PALLARES-BURKE, Maria Lucia Garcia. A imprensa periódica como uma empresa educativa no século XIX. Cadernos de Pesquisa, São Paulo, n. 104, jul. 1998.

PALUDO, Conceição. Educação popular como resistência e emancipação humana. Cadernos CEDES, Campinas, v. 35, n. 96, maio/ago. 2015.

PALUDO, Conceição; MACHADO, Rita de Cássia Fraga; GRITTI, Silvana Maria. A relação trabalho/educação no desafio de superar o desemprego permanente. Educação UNISINOS, São Leopoldo, v. 18, n. 2, maio/ago. 2014.

PARADISE, Ruth. Estilo interacional e o significado não verbal: crianças Mazahua aprendem como viver no modo separado-mas-junto. Práxis Educativa, Ponta Grossa, v. 7, n. esp, 2012.

PARASKEVA, João. [D] escolarização: genotexto e fenotexto das políticas curriculares neoliberais. Cadernos de Educação, Pelotas, n. 18, jan./jun. 2002.

PARÉ, Marilene Leal; OLIVEIRA, Luana Paré de; VELLOSO, Alessandra D’Aqui. A educação para quilombolas: experiências de São Miguel dos Pretos em Restinga Seca (RS) e da Comunidade Kalunga de Engenho II (GO). Cadernos CEDES, Campinas, v. 27, n. 72, maio/ago. 2007.

PASCOAL, Miriam. O pedagogo na empresa. Revista Diálogo Educacional, Curitiba, v. 7, n. 22, set./dez. 2007.

PASSOS, Luiz Augusto. Educação popular: um projeto de rebeldia e alteridade. Revista de Educação Pública, Cuiabá, v. 16, n. 31, maio/ago. 2007.

PATO, Claudia; SÁ, Lais Mourão; CATALÃO, Vera Lessa. Mapeamento de tendências na produção acadêmica sobre educação ambiental. Educação em Revista, Belo Horizonte, v. 25, n. 3, dez. 2009.

PAULA, Ercília Maria Angeli Teixeira de. Crianças e adolescentes que voam em jaulas: a tecnologia promovendo a liberdade no hospital. Cadernos CEDES, Campinas, v. 27, n. 73, set./dez. 2007.

PAULA, Ercília Maria Angeli Teixeira de; MACHADO, Érico Ribas. Pedagogia: concepções e práticas em transformação. Educar em Revista, Curitiba, n. 35, set./dez. 2009. 
PAULA, Ercília Maria Angeli Teixeira de; SANTA CLARA, Cristiane Aparecida Woytichoski de. Projetos de educação não-formal na cidade de Ponta Grossa - PR: análise de currículos e práticas. Práxis Educativa, Ponta Grossa, v. 3, n. 2, 2008.

PAULA, Eunice Dias de. Aprender com as crianças indígenas: mudando a lógica neocolonial presente nos processos de escolarização. Revista de Educação Pública, Cuiabá, v. 22, n 49/2, maio/ago. 2013.

PEDRO, Neuza; PIEDADE, João. Efeitos da formação na autoedicácia e na utilização educativa das TIC pelas professores: estudo das diferenças entre regimes formais e informais de formação. E-Curriculum, São Paulo, v. 11, n. 3, set./dez. 2013.

PEDROSO-JÚNIOR, Nelson N.; SATO, Michèle. Percepção da fauna terrestre e conservação no Parque Nacional de Superagüi através da educação ambiental. Revista de Educação Pública, Cuiabá, v. 12, n. 21, jan/jun. 2003.

PEIXOTO, Joana. Relações entre sujeitos sociais e objetos técnicos uma reflexão necessária para investigar os processos educativos mediados por tecnologias. Revista Brasileira de Educação, Rio de Janeiro, v. 20, n. 61, abr./jun. 2015.

PEREIRA, Ana Maria; ARAÚJO, Maria de Lourdes de. Sociodrama, saúde e educação. Linhas Críticas, Brasília, v. 4, n. 7-8, jul./jun. 1999.

PEREIRA, Antonio. A epistemologia da educação social de rua do Projeto Axé: um estudo de análise documental. Educação em Questão, Natal, v. 39, n. 25, set./dez. 2010.

PEREIRA, Cátia Maria Machado da Costa et al. Ecopedagogia: uma nova pedagogia com propostas educacionais para o desenvolvimento sustentável. Educação Temática Digital, Campinas, v. 8, n. 2, 2007.

PEREIRA, Marcelo de Andrade. Ne pas toucher aux œuvres: o princípio da (in)tangibilidade da obra de arte no contexto de sua exibição e suas (contra)significações pedagógicas. Educar em Revista, Curitiba, n. 49, jul./set. 2013.

PEREIRA, Maria Odete da Rosa. Educação ambiental com pescadores artesanais: um convite à participação. Práxis Educativa, Ponta Grossa, v. 3, n. 1, 2008.

PEREIRA, Sónia; VILAÇA, Teresa. Educação em sexualidade de mães adolescentes institucionalizadas num centro de apoio à vida. Revista Ibero-Americana de Estudos em Educação, v. 10, n. especial 2, 2015.

PEREIRA, Teresa Adelaide Ribeiro; VILAÇA, Teresa. Percepções sobre a abordagem educativa na reabilitação da sexualidade em contexto hospitalar. Revista Ibero-Americana de Estudos em Educação, v. 7, n. 2, abr./jun. 2012.

PERES, Marco Augusto de Castro. A andragogia no limiar da relação entre velhice, trabalho e educação. Contrapontos, Itajaí, v. 6, n. 1, jan./abr. 2006.

PERETTA, Éden Silva. Potências da carne, poesias do corpo. Educação Temática Digital, Campinas, v. 15, n. 3, set./dez. 2013.

PEREZ, Deivis. Definição e abordagem de currículo: exame de um curso de formação de professores para a educação não formal em ONGs. Educação (UFSM), Santa Maria, v. 39, n. 2, maio/ago. 2014. 
PESSOA, Jadir de Morais. Aprender fazendo: a criança na lógica do trabalho rural. InterAção, Goiânia, v. 21, n. 1-2, jan./dez. 1997.

Mestres de caixa e viola. Cadernos CEDES, Campinas, v. 27, n. 71, jan./abr. 2007.

PETITAT, André. Educação difusa e relação social. Educação \& Realidade, Porto Alegre, v. 36, n. 2, maio/ago. 2011.

PIMENTA, Ana Cláudia et al. Educação cidadã: uma metodologia de proteção integral a crianças e adolescentes. Revista da FAEEBA, Salvador, n. 14, jul./dez, 2000.

PIMENTA, Mayana Flávia Ferreira; NARDELLI, Aurea Maria Brandi. Desenvolvimento sustentável: os avanços na discussão sobre os temas ambientais lançados pela conferência das Nações Unidas sobre o desenvolvimento sustentável, Rio+20 e os desafios para os próximos 20 anos. Perspectiva, Florianópolis, v. 33, n. 3, set./dez. 2015.

PIMENTEL, Álamo. As lições das coisas. Linhas Críticas, Brasília, v. 21, n. 44, jan./abr. 2015a.

Brincadeiras de rua, convivência urbana e ecologia dos saberes. Revista Brasileira de Educação, Rio de Janeiro, v. 20, n. 62, jul./set. 2015b.

PINHEIRO, Áurea da Paz. Patrimônio cultural e museus: por uma educação dos sentidos. Educar em Revista, Curitiba, n. 58, out./dez. 2015.

PINHEIRO, Daiane; LAZZARIN, Márcia Lise Lunardi. Produções culturais surdas no YouTube: estratégias de produção, negociação e consumo de identidades. Educação e Cultura Contemporânea, Rio de Janeiro, v. 10, n. 21, jul./dez. 2013.

PINTO, Luiz Fernando. Educação, mídia e ética no admirável (?) ou abominável (?) mundo pornô. Revista da FAEEBA, Salvador, n. 7, jan./junho, 1997.

PINTO, Maria Helena. Evidências patrimoniais para a educação histórica: uma experiência educativa no Centro Histórico de Guimarães. Currículo sem Fronteiras, v. 7, n. 1, jan./jun. 2007.

PINTO, Mércia. Pastoril: educação sentimental e construção do imaginário numa festa popular brasileira. Linhas Críticas, Brasília, v. 8, n. 14, jan./jun. 2002.

PINTO, Silmara Cristiane et al. Ensino de filosofia em espaços não formais: notas de uma experiência. Educação (UFSM), Santa Maria, v. 40, n. 3, set./dez. 2015.

PIREDDU, Mario. Redes e conhecimento: as dimensões do social learning. Em Aberto, Brasília, v. 28, n. 94, jul./dez. 2015.

PISCHETOLA, Magda; MIRANDA, Lyana Thediga. Metodologias participativas e projeto UCA: a busca pela tecnologia como cultura. Perspectiva, Florianópolis, v. 33, n. 2, maio/ago. 2015.

PITANO, Sandro de Castro; NOAL, Rosa Elena. Horizontes de diálogo em educação ambiental: contribuições de Milton Santos, Jean-Jacques Rousseau e Paulo Freire. Educação em Revista, Belo Horizonte, v. 25, n. 3, dez. 2009.

POCHMANN, Marcio. Trabalho e formação. Educação \& Realidade, Porto Alegre, v. 37, n. 2, maio/ago. 2012. 
PONTES, Aldo. Do homo sapiens ao homo cibernéticus: uma reflexão sobre a relação homem-tecnologia. Educação Temática Digital, Campinas, v. 2, n. 2, 2001.

PORRAS-GALLO, María-Isabel. La poliomielits en la España franquista: educar e reeducar. Educar em Revista, Curitiba, n. 54, out./dez. 2014.

PORTO, Tania Maria Esperon. Uma mirada na trajetória docente: cartas de quem ensina. Revista Diálogo Educacional, Curitiba, v. 5, n. 15, maio/ago. 2005.

POSSAMAI, Zita Rosane. Exposição, coleção, museu escolar: ideias preliminares de um museu imaginado. Educar em Revista, Curitiba, n. 58, out./dez. 2015.

PRAZERES, Michelle. Educação não escolar de adultos e comunicação: um estado da arte 1999 a 2006. E-Curriculum, São Paulo, v. 7, n. 3, dez. 2009.

PRETTO, Nelson. Redes colaborativas, ética hacker e educação. Educação em Revista, Belo Horizonte, v. 26, n. 3, dez. 2010.

PRETTO, Nelson; FERREIRA, Simone de Lucena. Educação, inclusão sociodigital e o sistema brasileiro de televisão digital. Linhas Críticas, Brasília, v. 13, n. 24, jan./jun. 2007.

PRUDENTE, Celso Luiz. A dimensão pedagógica da alegoria carnavalesca no cinema negro enquanto arte de afirmação ontológica da africanidade: pontos para um diálogo com Merleau-Ponty. Revista de Educação Pública, Cuiabá, v. 23, n. 53/1, maio/ago. 2014.

QUINTÃO, Vânia Lúcia. Televisão e mediação pedagógicas. Linhas Críticas, Brasília, v. 5, n. 9, jul./dez. 1999.

RABELO, Miriam C. M.; SANTOS, Rita Maria Brito. Notas sobre o aprendizado no candomblé. Revista da FAEEBA, Salvador, n. 35, jan./jun. 2011.

RAMOS, Elisabeth Christmann. Educação ambiental: origem e perspectivas. Educar em Revista, Curitiba, n. 18, jul./dez. 2001.

RAMOS, Luís Marcelo Alves; BAGNATO, Maria Helena Salgado. Considerações sobre a proposta educativa de prevenção da AIDS em locais de trabalho da Coordenação Nacional de DST/AIDS (CN - DST/AIDS) do Ministério da Saúde. Educação Temática Digital, Campinas, v. 4, n. 1, 2002.

RAMOS, Tais Nascarella. Semeando a cidadania: um estudo sobre a formação e a atuação de educadoras sociais em prol do letramento. Teias, Rio de Janeiro, v. 12, n. 25, maio./ago. 2011.

RANGEL, Hugo. Estratégias sociais e educação prisional na Europa: visão de conjunto e reflexões. Revista Brasileira de Educação, Rio de Janeiro, v. 12, n. 34, jan./abr. 2007.

REAL, Márcio Penna Corte. As musicalidades das rodas de capoeira: investigação de um campo de saber/poder?. Inter-Ação, Goiânia, v. 39, n. 1, jan./abr. 2014.

REDIN, Euclides; ZITKOSKI, Jaime José; WÜRDIG, Rogério Costa. Políticas públicas para a cidade educadora na perspectiva da infância: interfaces entre o lúdico, a escola e a cidadania. Educação UNISINOS, São Leopoldo v. 7, n. 13, jul./dez. 2003.

REGIS, Kátia Evangelista. Alfabetização e pós-alfabetização de jovens e adultos e educação popular - concepções, limites e possibilidades das práticas do centro de educação e organização popular (CEOP) 1989-2004. E-Curriculum, São Paulo, v. 1, n. 1, jul. 2005. 
Educação não-escolar de adultos e relações etnicorraciais. E-Curriculum, São Paulo, v. 7, n. 3, dez. 2009.

REGO, Nelson. Geração de ambiências: três conceitos articuladores. Educação (PUCRS), Porto Alegre, v. 33, n. 1, 2010.

REIS JUNIOR, João (Alegria) Alves dos. Decifra-me ou devoro-te. Cadernos CEDES, Campinas, v. 25, n. 65, jan./abr. 2005.

RETTORI, Annelisse; GUIMARÃES, Helen. Comunidades virtuais de aprendizagem CVAS: uma visão dos ambientes interativos de aprendizagem. Revista da FAEEBA, Salvador, n. 22, jul./dez, 2004.

REZENDE, Maria Aparecida; PASSOS, Luiz Augusto. Encruzilhadas da interculturalidade: os difíceis caminhos na educação da mulher xavante. Cadernos de Educação, Pelotas, n. 43, set./dez. 2012.

REZENDE, Paula Cristina Medeiros; OLIVEIRA, Tamara Rossi de. Parangolé: arte, infância e educação. Pro-Posições, Campinas, v. 25, n. 2, maio/ago. 2014.

RIBEIRO, Emerson da Silva; DARSIE, Marta Maria Pontin. Educação de jovens e adultos: concepção e especificidades. Revista de Educação Pública, Cuiabá, v. 17, n. 33, jan./abr. 2008.

RIBEIRO, Hidelberto de Sousa; RIBEIRO, Marilene Marzari. Educação informal, formal e não-formal. Revista de Educação Pública, Cuiabá, v. 12, n. 21, jan/jun. 2003.

RIBEIRO, Jorge Alberto Rosa et al. A trajetória social de grupos etários maduros na aprendizagem digital. Currículo sem Fronteiras, v. 8, n. 2, jul./dez. 2008.

RIBEIRO, Kátia Suely Queiroz Silva. A experiência na extensão popular e a formação acadêmica em fisioterapia. Cadernos CEDES, Campinas, v. 29, n. 79, set./dez. 2009.

RIBEIRO, Marlene. "Cuidado de si" numa perspectiva ético-política na relação entre trabalho cooperativo e educação. Educação UNISINOS, São Leopoldo, v. 8, n. 14, jan./jun. 2004.

Educação popular: um projeto coletivo dos movimentos sociais populares. Perspectiva, Florianópolis, v. 26, n. 1, jan./jun. 2008.

Trabalho e educação no movimento camponês: liberdade ou emancipação?. Revista Brasileira de Educação, Rio de Janeiro, v. 14, n. 42, set./dez. 2009.

RIBEIRO, Regiane Regina. Escola, mídia e comunicação: sistemas complexos. Inter-Ação, Goiânia, v. 34, n. 1, jan./jun. 2009.

RICHTER, Sandra. Bachelard e a experiência poética como dimensão educativa da arte. Educação (UFSM), Santa Maria, v. 31, n. 2, jul./dez. 2006.

RINK, Juliana; MEGID NETO, Jorge. Tendências dos artigos apresentados nos Encontros de Pesquisa em Educação Ambiental (EPEA). Educação em Revista, Belo Horizonte, v. 25, n. 3, dez. 2009.

RIOS, Guilhermo A. As cidades como cenários de uma aprendizagem integradora. Em Aberto, Brasília, v. 25, n. 88, jul./dez. 2012. 
RIOS, Luís Felipe et al. Rumo à adultez: oportunidades e barreiras para a saúde sexual dos jovens brasileiros. Cadernos CEDES, Campinas, v. 22, n. 57, ago. 2002.

ROCHA, Ronaldo Gazal. Ecoideologias associadas aos movimentos ambientais: contribuições para o campo da educação ambiental. Educar em Revista, Curitiba, n. 27, jan./jun. 2006.

RODRIGUES, Ângela Beatriz Cavalli. Saberes do trabalho dos leituristas de hidrômetros. Educação UNISINOS, São Leopoldo, v. 10, n. 2, maio/ago. 2006.

RODRIGUES, Antonia Brito; COSTA, Nadja Maria Castilho da. A mobilização popular e comunitária para a implantação de programas de educação ambiental. Teias, Rio de Janeiro, v. 3, n. 6, jul./dez. 2002.

RODRIGUES, Cae. O vagabonding como estratégia pedagógica para a "desconstrução fenomenológica" em programas experienciais de educação ambiental. Educação em Revista, Belo Horizonte, v. 31, n. 1, jan./mar. 2015.

RODRIGUES, Fabiana de Cássia. Balanço da produção de conhecimentos sobre educação não escolar de adultos: educação no campo, 1998-2006. E-Curriculum, São Paulo, v. 7, n. 3, dez. 2009.

RODRIGUES, Jéssica do Nascimento; GUIMARÃES, Mauro. Algumas contribuições marxistas à educação ambiental (EA) crítico-transformadora. Revista de Educação Pública, Cuiabá, v. 20, n. 44, set./dez. 2011.

RODRIGUES, Jéssica do Nascimento; LOUREIRO, Carlos Frederico Bernardo. A crise socioambiental e a atuação de ONGs ambientalistas no campo educacional. Linhas Críticas, Brasília, v. 18, n. 36, maio/ ago. 2012.

RODRIGUES, Maria Emilia de Castro. A experiência de educação popular do centro popular de cultura em Goiás. Inter-Ação, Goiânia, v. 36, n. 2, jul./dez. 2011.

RODRIGUEZ, Victor Amar. El cine por una educación ambiental. Educação \& Realidade, Porto Alegre, v. 34, n. 3, set./dez. 2009.

ROSSEL, Nélida Cespedes. Paulo Freire está vivo no movimento da educação popular. Linhas Críticas, Brasília, v. 18, n. 37, set./ dez. 2012.

ROSSO, Ademir José; SANTOS, Franciely Ribeiro dos. Terceira idade, Natalidade e educação ambiental numa perspectiva intergeracional e arendtiana. Contrapontos, Itajaí, v. 10, n. 2, maio/ago. 2010.

RUIZ, Adriano Rodrigues. Tecnologias, aprendizagem da atenção e aprender a estudar. Educar em Revista, Curitiba, n. 55, jan./mar. 2015.

RUMMERT, Sonia Maria. Projeto escola de fábrica - atendendo a "pobres e desvalidos da sorte" do século XXI. Perspectiva, Florianópolis, v. 23, n. 2, jul./dez. 2005.

Educação de jovens e adultos trabalhadores no Brasil atual: do simulacro à emancipação. Perspectiva, Florianópolis, v. 26, n. 1, jan./jun. 2008.

Educar, qualificar: caminhos e descaminhos da educação de jovens e adultos trabalhadores. Perspectiva, Florianópolis, v. 31, n. 2, maio/ago. 2013. 
RUSCHEINSKY, Aloísio. Do fundamental de Paulo Freire: educação, cidadania e movimento social. Estudos Leopoldenses, São Leopoldo, v. 3, n. 4, jan./jun. 1999.

Meio ambiente, representação social e educação ambiental. Revista de Educação Pública, Cuiabá, v. 11, n. 20, jul./dez. 2002.

Sociologia das representações sociais e a educação ambiental. Contrapontos, Itajaí, v. 3, n. 1, jan./abr. 2003.

RUSSO, Kelly. Vídeos educativos e o diálogo entre culturas: professores indígenas e a apropriação da linguagem audiovisual. Teias, Rio de Janeiro, v. 8, n. 14-15, jan./dez. 2007.

SÁ, Lais Mourão. Educação ambiental e ecologia humana fundamentos para um debate. Linhas Críticas, Brasília, v. 2, n. 2, 1996.

jul./dez. 2001.

A educação ambiental na gestão municipal. Linhas Críticas, Brasília v. 7, n. 13,

SÁ, Ricardo Antunes de. Pedagogia: identidade e formação. O trabalho pedagógico nos processos educativos não-escolares. Educar em Revista, Curitiba, n. 16, jan./dez. 2000.

SALES, Celecina de Maria Veras. Juventude, espaços de formação e modos de vida. Educação Temática Digital, Campinas, v. 12, n. esp, 2010.

SALUSTIANO, Silvia Ferreira Marques et al. A educação ambiental e o turismo ecológico. Educação Temática Digital, Campinas, v. 9, n. 1, 2007.

SAMPAIO, Shaula Maíra Vicentini de; GUIMARÃES, Leandro Belinaso. Educação ambiental: tecendo trilhas, escriturando territórios. Educação em Revista, Belo Horizonte, v. 25, n. 3, dez. 2009.

SANCHES, Simone Meyer; RUBIO, Kátia. A prática esportiva como ferramenta educacional: trabalhando valores e a resiliência. Educação e Pesquisa, São Paulo, v. 37, n. 4, dez. 2011.

SANTANA, Willian Cardoso; MAGALHÃES, Hilda Gomes Dutra. Marketing verde como ferramenta para a educação ambiental. Inter-Ação, Goiânia, v. 33, n. 1, jan./jun. 2008.

SANTIAGO, Dileta da Rosa. O ensino da literatura na visualidade do cinema: a ficção dentro e fora da sala de aula. Práxis Educativa, Ponta Grossa, v. 2, n. 2, 2007.

SANTOS, Andréia Inamorato dos. Os discursos acerca de recursos educacionais abertos: este mundo é plano?. Educação e Cultura Contemporânea, Rio de Janeiro, v. 10, n. 21, jul./dez. 2013.

SANTOS, Ediógenes Aragão; MONTEIRO, Regina Maria. O Brasil de Olavo Bilac e Manoel Bonfim: a construção política de uma identidade nacional através do ensino. ProPosições, Campinas, v. 13, n. 2, 2002.

SANTOS, Edméa. Ambientes virtuais de aprendizagem: por autorias livres, plurais e gratuitas. Revista da FAEEBA, Salvador, n. 18, jul./dez, 2002.

A mobilidade cibercultural: cotidianos na interface educação e comunicação. Em Aberto, Brasília, v. 28, n. 94, jul./dez. 2015. 
SANTOS, Edméa; PONTE, Felipe Silva; ROSSINI, Tatiana Stofella Sodré. Autoria em rede: uma prática pedagógica emergente. Revista Diálogo Educacional, Curitiba, v. 15, n. 45, 2015 .

SANTOS, Edvalter Souza. Educação e sustentabilidade. Revista da FAEEBA, Salvador, n. 18, jul./dez, 2002.

SANTOS, Eloisa Helena. Contribuições da "pedagogia da ferramenta" para uma pedagogia do trabalho. Educação UNISINOS, São Leopoldo, v. 10, n. 2, maio/ago. 2006.

SANTOS, Fernando Passos dos; CHALUB-MARTINS, Leila. Agroecologia, consumo sustentável e aprendizado coletivo no Brasil. Educação e Pesquisa, São Paulo, v. 38, n. 2, abr./jun. 2012.

SANTOS, José Eduardo Ferreira. Práticas pedagógicas, cultura, história e tradição: um relato da experiência educativa em Novos Alagados. Revista da FAEEBA, Salvador, n. 19, jan./jun, 2003.

SANTOS, Mateus Casanova dos et al. Resgate histórico de um grupo rural de estudos das plantas medicinais: educação em saúde. Cadernos de Educação, Pelotas, n. 39, maio./ago. 2011.

SANTOS, Vanessa Matos dos; KERBAUY, Maria Teresa Miceli. Interatividade em ambiente virtual de aprendizagem: contribuições de uma experimentação. Revista IberoAmericana de Estudos em Educação, v. 4, n. 3, set./dez. 2009.

SARMENTO, Diva Chaves et al. Sistemas de ensino no Brasil: formação da identidade nacional e efeitos da globalização. Educação em Foco (UFJF), Juiz de Fora, v. 14, n. 2, set. 2009/fev. 2010.

SARRETA, Fernanda de Oliveira; BERTANI, Iris Fenner. Perspectivas da educação permanente em saúde. Revista Ibero-Americana de Estudos em Educação, v. 4, n. 3, set./dez. 2009.

SATO, Michèle et al. Nossa palavra é sim. Revista de Educação Pública, Cuiabá, v. 17, n. 33, jan./abr. 2008.

SCALABRIN, Rosemeri; PAIVA, Irene Alves de. O protagonismo dos movimentos sociais e sujeitos na materialização da educação do-no campo. Educação em Questão, Natal, v. 32, n. 18, maio/ago. 2008.

SCARELI, Giovana. Construção fílmica e educação: um olhar para o filme Santo Forte de Eduardo Coutinho. Educação Temática Digital, Campinas, v. 12, n. 1, 2010.

SCHERER-WARREN, Ilse. Educação popular e diálogo intercultural. Revista de Educação Pública, Cuiabá, v. 11, n. 19, jan./jul. 2002a.

Movimentos sociais e educação na era da informação. Revista de Educação Pública, Cuiabá, v. 11, n. 19, jan./jul. 2002b.

SCHÜTZ, Rosalvo. Educação, movimentos sociais populares e democracia: confluências explícitas e implícitas. Cadernos de Educação, Pelotas, n. 32, jan./abr. 2009.

SCHWARTZ, Yves. Transmissão e ensino: do mecânico ao pedagógico. Pro-Posições, Campinas, v. 16, n. 3, 2005. 
SCHWENDLER, Sônia Fátima. O processo pedagógico da luta de gênero na luta pela terra: o desafio de transformar práticas e relações sociais. Educar em Revista, Curitiba, n. 55, jan./mar. 2015.

SCOCUGLIA, Afonso Celso. História e educação popular na Paraibrasil (1961/1970). Revista de Educação Pública, Cuiabá, v. 8, n. 14, jun./dez. 1999.

SCOTT, Jeff. Viagens pelo campo virtual: aprendendo além dos muros da sala de aula. Linhas Críticas, Brasília, v. 18, n. 35, jan./ abr. 2012.

SELIGMAN, Laura. Entrevista com Joan Ferrés. Contrapontos, Itajaí, v. 8, n. 2, maio/ago. 2008.

SEVERO, José Leonardo Rolim de Lima. Educação não escolar como campo de práticas pedagógicas. Revista Brasileira de Estudos Pedagógicos, Brasília, v. 96, n. 244, set./dez. 2015.

SEVERO, José Leonardo Rolim de Lima; PIMENTA, Selma Garrido. A pedagogia entre o passado e a contemporaneidade: apontamentos para uma ressignificação epistemológica. Inter-Ação, Goiânia, v. 40, n. 3, set./dez. 2015.

SILVA, Ana Maria Costa e. Desafios contemporâneos para a formação de jovens e adultos. Educar em Revista, Curitiba, n. 29, jan./jun. 2007.

SILVA, Carmen Silvia Maria da. Educação não escolar de adultos: gênero e mulheres. ECurriculum, São Paulo, v. 7, n. 3, dez. 2009.

SILVA, Daniel Monteiro da. ONGs e escolas públicas: a palavra dos educadores. Educação Temática Digital, Campinas, v. 12, n. 2, 2011.

SILVA, Danielle Mesquita da Costa; GRILLO, Margareth. A utilização de jogos educativos como instrumento de educação ambiental: o caso Reserva Ecológica de Gurjaú (PE). Contrapontos, Itajaí, v. 8, n. 2, maio/ago. 2008.

SILVA, Gerson Heidrich da. Educador social: uma identidade a caminho da profissionalização?. Educação e Pesquisa, São Paulo, v. 35, n. 3, set./dez. 2009.

SILVA, Ivanderson Pereira da; MERCADO, Luis Paulo Leopoldo. Levantamento dos temas TIC e EAD na biblioteca virtual Educ@. Cadernos de Pesquisa, São Paulo, v. 45, n. 158, out./dez. 2015.

SILVA, Kássya Christinna Oliveira da; OLIVEIRA, Ivanilde Apoluceno de. Representações sobre o Eu e o Outro em ambiente hospitalar. Educação em Questão, Natal, v. 34, n. 20, jan./abr. 2009.

SILVA, Katharine Ninive Pinto. Formação de trabalhadores em lazer: por uma educação no e para o tempo livre. Currículo sem Fronteiras, v. 13, n. 1, jan./abr. 2013.

SILVA, Lenildes Ribeiro. UNESCO: Os quatro pilares da "educação pós-moderna. InterAção, Goiânia, v. 33, n. 2, jul./dez. 2008.

SILVA, Lourdes Helena da; COSTA, Vânia Aparecida; ROSA, Walquíria Miranda. A educação de jovens e adultos em áreas de reforma agrária: desafios da formação de educadores do campo. Revista Brasileira de Educação, Rio de Janeiro, v. 16, n. 46, jan./abr. 2011. 
SILVA, Marcos José Pereira da; MARQUES, Mariana Pasqual. Balanço da produção discente sobre educação não-escolar de adultos e educação política: 1999 a 2006 . ECurriculum, São Paulo, v. 7, n. 3, dez. 2009.

SILVA, Maria Carolina da Silva; PARAÍSO, Marlucy Alves. A infância no currículo de filmes de animação: poder, governo e subjetivação dos/as infantis. E-Curriculum, São Paulo, v. 8, n. 1, abr. 2012.

SILVA, Maurício Camillo da. A violência e os seus impasses na vida cotidiana dos educadores de rua - breve recorte provocativo. Cadernos CEDES, Campinas, n. 38, 1996.

SILVA, Percival Tavares da. A práxis da formação política das classes populares. Revista de Educação Pública, Cuiabá, v. 16, n. 31, maio/ago. 2007.

SILVA, Regina; JABER-SILVA, Michelle. O mapa social e a educação ambiental, diálogos de um mapeamento participativo no Pantanal, Mato Grosso, Brasil. Revista de Educação Pública, Cuiabá, v. 24, n. 55, jan./abr. 2015.

SILVA, Regina; JABER, Michelle; SATO, Michèle. Tecendo a educação ambiental com fios amazônicos. Revista de Educação Pública, Cuiabá, v. 19, n. 39, jan./abr. 2010.

SILVA, Roberto da. A eficácia sociopedagógica da pena de privação da liberdade. Educação e Pesquisa, São Paulo, v. 41, n. 1, jan./mar. 2015.

SILVA, Rodrigo Manoel Dias da. Políticas socioculturais brasileiras e os interesses formativos do Programa Cultura Viva. Revista Brasileira de Estudos Pedagógicos, Brasília, v. 94, n. 236, jan./abr. 2013.

Educação, cidadania e agenciamentos formativos nas políticas culturais brasileiras.

Educação \& Sociedade, Campinas, v. 35, n. 127, abr./jun. 2014.

Educação patrimonial e a dissolução das monoidentidades. Educar em Revista, Curitiba, n. 56, abr./jun. 2015.

SILVA, Rogério Correia da. Participação e aprendizagem na educação da criança. Revista Brasileira de Educação, Rio de Janeiro, v. 19, n. 58, jul./set. 2014.

SILVA, Rogerio Correia. Circulando com os meninos: infância, participação e aprendizagens de meninos indígenas Xakriabá. Educação em Foco (UEMG), Belo Horizonte, v. 15, n. 20, 2012.

SILVA, Ronalda Barreto. Educação comunitária: além do estado e do mercado?. Cadernos de Pesquisa, São Paulo, n. 112, mar. 2001.

Movimentos sociais, educação e saúde mental: a inclusão social pelo trabalho.

Revista da FAEEBA, Salvador, n. 34, jul./dez. 2010.

SILVA, Sheyla Pinto da. Considerações sobre o relacionamento amoroso entre adolescentes. Cadernos CEDES, Campinas, v. 22, n. 57, ago. 2002.

SILVA, Solange Pereira da; TORRES, Artemis. A contribuição pedagógica das Ligas Camponesas na história das lutas no campo brasileiro. Revista de Educação Pública, Cuiabá, v. 24, n. 57, set./dez. 2015. 
SILVA, Walkiria Sousa; LUNA, José Marcelo Freitas de. As culturas de infância e produção de sentidos: um estudo de recepção midiática com crianças. Inter-Ação, Goiânia, v. 39, n. 3, set./dez. 2014.

SILVEIRA, Eduardo. A arte do encontro: a educação estética ambiental atuando com o teatro do oprimido. Educação em Revista, Belo Horizonte, v. 25, n. 3, dez. 2009.

SILVERIO, Luisa A. Noa. Evaluación de programas educativos en línea: diferentes aproximaciones. Educação em Questão, Natal, v. 20, n. 6, maio/ago. 2004.

SÍMILI, Ivana Guilherme; FRANQUI, Renata. As roupas e os gêneros: as estampas de brinquedos e de brincadeiras. Acta Scientiarum. Education, Maringá, v. 37, n. 3, jul./set. 2015.

SIMONS, Maarten; MASSCHELEIN, Jan. Sociedade da aprendizagem e governamentalidade: uma introdução. Currículo sem Fronteiras, v. 11, n. 1, jan./jun. 2011.

SIQUEIRA, Silvia Márcia Alves. Instruir as mulheres: admoestação à modéstia do De cultu feminarum de Tertuliano. Acta Scientiarum. Education, Maringá, v. 33, n. 2, jul./dez. 2011.

SMEKE, Elizabeth de Leone Monteiro; OLIVEIRA, Nayara Lúcia Soares de. Avaliação participante de práticas educativas em serviços de saúde. Cadernos CEDES, Campinas, v. 29, n. 79, set./dez. 2009.

SOARES, Leôncio José Gomes. A política de educação de adultos: a campanha de 1947. Educação em Revista, Belo Horizonte, n. 28, dez. 1998.

SOARES, Rosângela. Fica comigo: juventude e pedagogias amorosas/sexuais na MTV. Educação em Revista, Belo Horizonte, n. 46, dez. 2007.

SOARES, Rosângela; MEYER, Dagmar E. Estermann. O que se pode aprender com a "MTV de papel" sobre juventude e sexualidade contemporâneas?. Revista Brasileira de Educação, Rio de Janeiro, n. 23, maio/ago. 2003.

SOMMER, Luís Henrique; SCHMIDT, Saraí. Pedagogia da publicidade e produção da cultura infantil contemporânea. Educação UNISINOS, São Leopoldo, v. 17, n. 2 maio./ago. 2013.

SORRENTINO, Marcos et al. Educação ambiental como política pública. Educação e Pesquisa, São Paulo, v. 31, n. 2, maio/ago. 2005.

SOUSA, Carolina Silva; RODRÍGUEZ-MIRANDA, Francisco P. Envelhecimento e educação para resiliência no idoso. Educação \& Realidade, Porto Alegre, v. 40, n. 1, abr./mar. 2015.

SOUZA, Amaralina Miranda de. A formação do pedagogo para o trabalho no contexto hospitalar: a experiência da Faculdade de Educação da UnB. Linhas Críticas, Brasília, v. 17, n. 33, maio/ago. 2011.

SOUZA, Christiane Maria Cruz de. Conhecer e educar para controlar o câncer na Bahia. Educar em Revista, Curitiba, n. 54, out./dez. 2014.

SOUZA, Cláudio Benedito Gomide de; BIZELLI, José Luis; BASTOS, Alexandre Marucci. O município e a educação na era da informação. Revista Ibero-Americana de Estudos em Educação, v. 4, n. 1, jan./abr. 2009. 
SOUZA, Dileno Dustan Lucas de. A relação público e privado na lógica das Organizações Não Governamentais (ONGs). Educação em Foco (UFJF), Juiz de Fora, v. 19, n. 1, mar./jun. 2014.

SOUZA, Fabiana Rodrigues de. Ações educativas desenvolvidas por prostitutas organizadas: tecendo confiança e autonomia. Revista da FAEEBA, Salvador, v. 24, n. 43, jan./jun. 2015.

SOUZA, Janice Tirelli Ponte de; DURAND, Olga Celestina. Experiências educativas da juventude: entre a escola e os grupos culturais. Perspectiva, Florianópolis, v. 22, n. 2, jul./dez. 2002.

SOUZA, João Francisco de. Educação e sociedade na perspectiva freireana. Educação (PUCRS), Porto Alegre, ano XXV, n. 46, 2002.

SOUZA, Maria Antônia de. Formas cooperativas de produção em assentamentos rurais do MST (Movimento dos Trabalhadores Rurais Sem Terra): dimensões educativas. Educação Temática Digital, Campinas, v. 1, n. 2, 2000.

Processos educativos e organização de formas cooperativas de produção em assentamentos rurais do MST. Educação Temática Digital, Campinas, v. 4, n. 1, 2002.

SOUZA, Maria Celeste Reis Fernandes de; MEIRELES, Ludmylla Karinne Trigueiro; BICALHO, Maria Gabriela Parenti. Território e currículo: relações interdisciplinares entre estudos territoriais e educação social. Revista da FAEEBA, Salvador, v. 24, n. 43, jan./jun. 2015.

SOUZA, Sueli Ribeiro Mota. Educação e religião: notas sobre ensino e aprendizagem terapêuticas no SCS da IPDA. Revista da FAEEBA, Salvador, n. 35, jan./jun. 2011.

SOUZA NETO, Alaim; LUNARDI-MENDES Geovana. Uma epistemologia para a educação online. Educação e Cultura Contemporânea, Rio de Janeiro, v. 11, n. 25, 2014.

SPAZIANI, Raquel Baptista; PEREIRA, Patrícia Cristine; MAIA, Ana Cláudia Bortolozzi. Memórias da educação sexual: relatos de educadoras sobre a infância e adolescência. Revista Ibero-Americana de Estudos em Educação, v. 9, n. 3, jul./set. 2014.

SPOSITO, Marilia Pontes. Juventude e educação: interações entre a educação escolar e a educação não-formal. Educação \& Realidade, Porto Alegre, v. 33, n. 2, jul./dez. 2008.

Transversalidades no estudo sobre jovens no Brasil: educação, ação coletiva e cultural. Educação e Pesquisa, São Paulo, v. 36, n. especial, 2010.

SPOSITO, Marilia Pontes; SILVA, Hamilton Harley de Carvalho e; SOUZA, Nilson Alves de. Juventude e poder local: um balanço de iniciativas públicas voltadas para jovens em municípios de regiões metropolitanas. Revista Brasileira de Educação, Rio de Janeiro, v. 11, n. 32, maio/ago. 2006.

STEIL, Carlos Alberto; CARVALHO, Isabel Cristina de Moura; PASTORI, Erica Onzi. Educação ambiental no Rincão Gaia: pelas trilhas da saúde e da religiosidade numa paisagem ecológica. Educação (PUCRS), Porto Alegre, v. 33, n. 1, 2010.

STEPHANOU, Maria. Bem viver em regras: urbanidade e civilidade em manuais de saúde. Educação UNISINOS, São Leopoldo, v. 10, n. 1, jan./abr. 2006. 
STOER, Stephen R.; MAGALHÃES, António M. Educação, conhecimento e a sociedade em rede. Educação \& Sociedade, Campinas, v. 24, n. 85, dez. 2003.

STRECK, Danilo R. Educar a solidariedade: desafios pedagógicos para reinventar a comunidade. Educação UNISINOS, São Leopoldo v. 6, n. 10, jan./jun. 2002.

A educação popular e a (re)construção do público: há fogo sob as brasas?. Revista Brasileira de Educação, Rio de Janeiro, v. 11, n. 32, maio/ago. 2006.

Uma pedagogia do movimento: os movimentos sociais na obra de Paulo Freire. Revista de Educação Pública, Cuiabá, v. 18, n. 36, jan./abr. 2009.

- Entre emancipação e regulação: (des)encontros entre educação popular e movimentos sociais. Revista Brasileira de Educação, Rio de Janeiro, v. 15, n. 44, maio/ago. 2010.

Territórios de resistência e criatividade: reflexões sobre os lugares da educação popular. Currículo sem Fronteiras, v. 12, n. 1, jan./abr. 2012.

A pesquisa em educação popular e a educação básica. Práxis Educativa, Ponta Grossa, v. 8, n. 1, 2013.

Ecos de Angicos: temas freireanos e a pedagogia atual. Pro-Posições, Campinas, v. 25, n. 3 set./dez. 2014.

STRECK, Danilo R.; ADAMS, Telmo. Uma prática de pesquisa participante: análise da dimensão social, política e pedagógica. Revista de Educação Pública, Cuiabá, v. 20, n. 44, set./dez. 2011.

STRIEDER, Roque; HERBERT, Fabiana. Experiências formativas do outro diferente em ambientes de amizade. Educação (UFSM), Santa Maria, v. 40, n. 2, maio/ago. 2015.

SZYMANSKI, Heloisa. A família como um locus educacional: perspectivas para um trabalho psicoeducacional. Revista Brasileira de Estudos Pedagógicos, Brasília, v. 81, n. 197, jan./abr. 2000.

A contribuição de Paulo Freire para o desenvolvimento de práticas psicoeducativas no encontro escola, comunidade, família. E-Curriculum, São Paulo, v. 7, n. 3, dez. 2011.

SZYMANSKI, Heloisa; CALIL, Simone Dalla Barba Walckoff. Educação e trabalho: a prática psicoeducativa em uma cooperativa de trabalho. Contrapontos, Itajaí, v. 6, n. 1, jan./abr. 2006.

TAFURI, Diogo Marques; GONÇALVES JUNIOR, Luiz. Educação popular e o discurso da economia política eurocêntrica. Revista da FAEEBA, Salvador, v. 24, n. 43, jan./jun. 2015.

TAL, Tzv. Multiculturalismo y cine: una propuesta pedagógica en torno a imágenes de imigrantes en cine israelí actual. Práxis Educativa, Ponta Grossa, v. 1, n. 1, 2006.

TARTUCE, Gisela Lobo B. P. Balanço da produção de conhecimentos sobre educação não escolar de adultos: PLANFOR e educação do trabalhador, 1999-2006. E-Curriculum, São Paulo, v. 7, n. 3, dez. 2009.

TAUKANE, Darlene Yaminalo. Museu-oficina Kuikare: uma "escola" nativa Bakairi (Karib). Revista de Educação Pública, Cuiabá, v. 7, n. 12, jul./dez. 1998. 
TAVARES, Ana Cláudia Ribeiro; FERREIRA, Andréa Tereza Brito. Práticas e eventos de letramento em meios populares: uma análise das redes sociais de crianças de uma comunidade da periferia da cidade do Recife. Revista Brasileira de Educação, Rio de Janeiro, v, 14, n. 41, maio/ago. 2009.

TAVARES, Manuel. Culturas e educação: a retórica do multiculturalismo e a ilusão do interculturalismo. Educação e Cultura Contemporânea, Rio de Janeiro, v. 11, n. 25, 2014.

TAVARES, Maria Tereza Goudard. Educação popular e movimentos sociais contemporâneos: algumas notas para reflexão. Revista da FAEEBA, Salvador, v. 24, n. 43, jan./jun. 2015.

TAVARES, Mauricio Antunes. Para livrar o campo do amarelão, da maleita, do alcoolismo e do ofidismo. A educação rural em Pernambuco nos anos 1930 a 1950. Educar em Revista, Curitiba, n. 54, out./dez. 2014.

TEIVE, Gladys Mary Ghizoni. Sugestões sobre a educação popular no Brasil: proposta do Professor Orestes Guimarães. Currículo sem Fronteiras, v. 10, n. 2, jul./dez. 2010.

TEIXEIRA, Carlos Henrique; MONTEIRO, Sueli Aparecida Itman. A dança como expressão do imaginário. Revista Ibero-Americana de Estudos em Educação, v. 7, n. 3, jul./set. 2012.

TEIXEIRA, Edival Sebastião; ALGERI, Fernanda Luiza. Representações de meio ambiente e educação ambiental: um estudo com docentes de casas familiares rurais. Práxis Educativa, Ponta Grossa, v. 6, n. 2, 2011.

TEIXEIRA, Virgínia Mascarenhas Nascimento; MARQUES, Rita de Cássia. Enfermeiros e saúde pública em, Belo Horizonte: combatendo doenças e educando para a saúde (18971933). Educar em Revista, Curitiba, n. 54, out./dez. 2014.

TEODORO, Ana Paula Evaristo Guizarde; SCHWARTZ, Gisele Maria. Usabilidade de site sobre lazer para idosos. Educação Temática Digital, Campinas, v. 14, n. 2, jul./dez. 2012.

TIRIBA, Lia. Cultura do trabalho, produção associada e produção de saberes. Educação UNISINOS, São Leopoldo, v. 10, n. 2, maio/ago. 2006.

Brincando de casinha: fragmentos de economia, cultura e educação. Revista de Educação Pública, Cuiabá, v. 16, n. 31, maio/ago. 2007a.

Educação popular e pedagogia(s) da produção associada. Cadernos CEDES, Campinas, v. 27, n. 71, jan./abr. 2007b.

Cultura do trabalho, autogestão e formação de trabalhadores associados na produção: questões de pesquisa. Perspectiva, Florianópolis, v. 26, n. 1, jan./jun. 2008.

TIRIBA, Lia; FISCHER, Maria Clara Bueno. Espaços/tempos milenares dos povos e comunidades tradicionais: notas de pesquisa sobre economia, cultura e produção de saberes. Revista de Educação Pública, Cuiabá, v. 24, n. 56, maio/ago. 2015.

TOLEDO, Renata Ferraz de; PELICIONI, Maria Cecília Focesi. A educação ambiental nos parques estaduais paulistas no âmbito das recomendações de Tbilisi. Práxis Educativa, Ponta Grossa, v. 1, n. 2, 2006. 
TOLEDO, Valéria Diniz. Inclusão social na educação não formal: o Instituto Arte no Dique como experiência alternativa diante da crise do ensino escola. Revista de Educação PUCCampinas, Campinas, n. 27, jul./dez. 2009.

TOMASI, Antônio de Pádua Nunes. Formação ao longo da vida (FLV): o que o trabalhador quer aprender?. Educação em Foco (UEMG), Belo Horizonte, v. 16, n. 21, 2013.

TOMAZZONI, Airton. Lições de dança na mídia. Educação (PUCRS), Porto Alegre, v. 38, n. $1,2015$.

TONDIN, Mara Cristina; BARROS NETA, Maria da Anunciação P.; PASSOS, Luiz Augusto. Consultório de rua: intervenção ao uso de drogas com pessoas em situação de rua. Revista de Educação Pública, Cuiabá, v. 22, n 49/2, maio/ago, 2013.

TORRES, Ártemis. Educação em movimentos sociais: novos atores, novos desafios. Revista de Educação Pública, Cuiabá, v. 14, n. 26, jul./dez. 2005.

TORRES, Carlos Alberto. Política para educação de adultos e globalização. Currículo sem Fronteiras, v. 3, n. 2, jul./dez. 2003.

TORRES, Mariana de Oliveira Fernandes; CLARO, Jose Alberto Carvalho dos Santos. Pedagogia empresarial: a atuação dos profissionais da educação na gestão de pessoas. Contrapontos, Itajaí, v. 12, n. 2, maio/ago. 2012.

TORRES, Patrícia Lupion. Laboratório on-line de aprendizagem: uma experiência de aprendizagem colaborativa por meio do ambiente virtual de aprendizagem Eurek@Kids. Cadernos CEDES, Campinas, v. 27, n. 73, set./dez. 2007.

TOZONI-REIS, Marília Freitas de Campos. Temas ambientais como "temas geradores": contribuições para uma metodologia educativa ambiental crítica, transformadora e emancipatória. Educar em Revista, Curitiba, n. 27, jan./jun. 2006.

TRISTÃO, Martha. Tecendo os fios da educação ambiental: o subjetivo e o coletivo, o pensado e o vivido. Educação e Pesquisa, São Paulo, v. 31, n. 2, maio/ago. 2005.

A educação ambiental e o pós-colonialismo. Revista de Educação Pública, Cuiabá, v. 23, n. 53/2, maio/ago. 2014.

UJIIE, Nájela Tavares; NATALI, Paula Marçal; MACHADO, Érico Ribas. Contextos da formação do educador social no Brasil. Educação UNISINOS, São Leopoldo, v. 13, n. 2, maio/ago. 2009.

VALE, Sandra Maria do; FERREIRA, Carlos Alberto. Representações de formadores sobre a avaliação das aprendizagens em educação de adultos. Cadernos de Pesquisa, São Paulo, v. 45, n. 157, jul./set. 2015.

VALENÇA, Vera Lucia Chacon. A rede do imaginário infantil: um serviço de educação intercultural do Museu das Crianças do Brasil. Educação em Questão, Natal, v. 33, n. 19, set./dez. 2008.

O Museu da Crianças: educação, redes internacionais e acervo. Teias, Rio de Janeiro, v. 11, n. 21, jan./abr. 2010.

VALENTI, Mayla Willik et al. Educação ambiental em unidades de conservação: políticas públicas e a prática educativa. Educação em Revista, Belo Horizonte, v. 28, n. 1, mar. 2012. 
VARELA, Cristina; MELO, Sonia Maria Martins de. Educação sexual, crianças e mídias: algumas reflexões. Revista Ibero-Americana de Estudos em Educação, v. 10, n. 2, abr./jun. 2015.

VASCONCELLOS, Hedy Silva Ramos de et al. Espaços educativos impulsionadores da educação ambiental. Cadernos CEDES, Campinas, v. 29, n. 77, jan./abr. 2009.

VASCONCELLOS, Tânia de. Infância e patrimônio. Revista da FAEEBA, Salvador, n. 31, jan./jun. 2009.

VASCONCELOS, Eymard Mourão. Espiritualidade na educação popular em saúde. Cadernos CEDES, Campinas, v. 29, n. 79, set./dez. 2009.

VASCONCELOS, Eymard Mourão; VASCONCELOS, Marcos Oliveira Dias; SILVA, Marísia Oliveira da. A contribuição da educação popular para a reorientação das práticas e da política de saúde no Brasil. Revista da FAEEBA, Salvador, v. 24, n. 43, jan./jun. 2015.

VASCONCELOS, José Gerardo. Presos políticos e presos comuns: troca de experiência e ação pedagógica. Educação (UFSM), Santa Maria, v. 22, n. 2, jul./dez. 1997.

VASCONCELOS, Valéria Oliveira de; OLIVEIRA, Maria Waldenez de. Educação popular: uma história, um que-fazer. Educação UNISINOS, São Leopoldo, v. 13, n. 2, maio/ago. 2009.

VEIGA, Cynthia G. A escolarização como projeto de civilização. Revista Brasileira de Educação, Rio de Janeiro, n. 21, p. 90-170, set./dez. 2002.

VENDRAMINI, Célia Regina. A contribuição de E. P. Thompson para a apreensão dos saberes produzidos do/no trabalho. Educação UNISINOS, São Leopoldo, v. 10, n. 2, maio/ago. 2006.

Educação e trabalho: reflexões em torno dos movimentos sociais do campo. Cadernos CEDES, Campinas, v. 27, n. 72, maio/ago. 2007.

Os desafios do MST e da educação na atualidade brasileira. Perspectiva, Florianópolis, v. 31, n. 2, maio/ago. 2013.

VIANNA, Catia Maria Souza de Vasconcelos. Práticas culturais em museus: educação continuada para professores de EJA?. Teias, Rio de Janeiro, v. 15, n. 35, jan./mar. 2014.

VIEIRA, Elisa; AQUINO, Julio Groppa. Sobre a pedagogização da experiência urbana: o projeto da cidade educadora. Educação UNISINOS, São Leopoldo, v. 19, n. 3, set./dez. 2015.

VIEIRA, Fabio Pessoa. Por um envolvimento na educação ambiental. Educação Temática Digital, Campinas, v. 16, n. 3, set./dez. 2014.

VIEIRA, Jarbas Santos. Perpetuando pependências: uma leitura do apoio sócio-educativo em meio aberto na cidade de, Pelotas. Cadernos de Educação, Pelotas, n. 23, jul./dez. 2004.

VIEITEZ, Candido Giraldez; DAL RI, Neusa Maria. Aportes à pesquisa sobre educação e trabalho no Movimento dos Trabalhadores Rurais Sem Terra. E-Curriculum, São Paulo, v. 13, n. 2, abr./jun. 2015.

VILANOVA, Edvalda Cecília Abud. A relação educador-educando no Projeto Axé. Educar em Revista, Curitiba, n. 15, jul./dez. 1999. 
VINCENT, Guy; LAHIRE, Bernard; THIN, Daniel. Sobre a história e a teoria da forma escolar. Educação em Revista, Belo Horizonte, n. 33, p. 7-47, jun. 2001.

VITORINO, Artur José Renda; MONTANARI, Paula Bernadete. Produzir-se negro no Brasil: estudo dos dispositivos didático-pedagógicos na revista Raça Brasil. Educação Temática Digital, Campinas, v. 16, n. 1, jan./abr. 2014.

VOGT, Maria Saleti Lock; ALVES, Elioenai Dornelles. Revisão teórica sobre a educação de adultos para uma aproximação com a andragogia. Educação (UFSM), Santa Maria, v. 30, n. 2, jul./dez. 2005.

WALTER, Fernanda Omelczuk. O lugar do pedagógico nos filmes feitos para crianças. ProPosições, Campinas, v. 26, n. 3, set./dez. 2015.

WEIDE, Darlan Faccin; FARIA, Nedison. Quefazer pedagógico em acampamentos de Reforma Agrária no Rio Grande do Sul. Educação (UFSM), Santa Maria, v. 23, n. 1, jan./jun. 1998.

WERLE, Flávia Obino Corrêa. Ensino rural e legitimação das ações do Estado. Revista Diálogo Educacional, Curitiba, v. 13, n. 39, maio/ago. 2013.

WORTMANN, Maria Lúcia Castagna; RIPOLL, Daniela; POSSAMAI, Laís. Educação ambiental corporativa para crianças: analisando a animação Peixonauta do Discovery Kids. Perspectiva, Florianópolis, v. 30, n. 2, maio/ago. 2012.

XAVIER, Ismail. Um cinema que "educa" é um cinema que (nos) faz pensar. Educação \& Realidade, Porto Alegre, v. 33, n. 1, jan./jun. 2008.

XAVIER, Libânia Nacif. O debate em torno da nacionalização do ensino na Era Vargas. Educação (UFSM), Santa Maria, v. 30, n. 2, jul./dez. 2005.

XAVIER FILHA, Constantina. Produção de filme de animação com e para crianças: os pensamentos podem virar arte. Perspectiva, Florianópolis, v. 33, n. 3, set./dez. 2015.

ZAIAS, Elismara; PAULA, Ercilia Maria Angeli Teixeira de. A produção acadêmica sobre práticas pedagógicas em espaços hospitalares: análise de teses e dissertações. Educação UNISINOS, São Leopoldo v. 14, n. 3, set./dez. 2010.

ZAMBONI, Ernesta. Projeto pedagógico dos parâmetros curriculares nacionais: identidade nacional e consciência histórica. Cadernos CEDES, Campinas, v. 23, n. 61, dez. 2003.

ZANELLA, Maria Nilvane; LARA, Angela Mara de Barros. A ONU, suas normativas e o ordenamento jurídico para o atendimento de adolescentes em conflito com a lei no Brasil: as políticas de socioeducação. Educação Temática Digital, Campinas, v. 17, n. 1, jan./abr. 2015 .

ZARDO, Sinara Pollom; FREITAS, Soraia Napoleão. Educação em classes hospitalares: transformando ações e concepções à luz da teoria da complexidade. Educar em Revista, Curitiba, n. 30, jul./dez. 2007.

ZILLE, José Antônio Baêta. Games, indicadores e geradores de possibilidades educacionais.

Revista Ibero-Americana de Estudos em Educação, v. 6, n. 3, set./dez. 2011. 
ZITKOSKI, Jaime José. Cidade educadora e emancipação social: o desafio da educação fundamentada numa razão dialógica. Educação UNISINOS, São Leopoldo, v. 9, n. 2, maio/ago. 2005.

ZOIA, Alceu; PERIPOLLI, Odimar João. Infância indígena: relações educativas nos diversos contextos. Revista de Educação Pública, Cuiabá, v. 22, n 49/2, maio/ago, 2013.

ZUCCHETTI, Dinora Tereza; MOURA, Eliana Perez Gonçalves de. Educação não-escolar: refletindo sobre práticas para uma (outra) epistemologia da pedagogia. Contrapontos, Itajaí, v. 7, n. 1, jan./abr. 2007.

ZUCCHETTI, Dinora Tereza; MOURA, Eliana Perez Gonçalves de; MENEZES, Magali Mendes de. Ações socioeducativas: da cultura do trabalho ao trabalho da cultura. Educação UNISINOS, São Leopoldo, v. 18, n. 2, maio/ago. 2014.

ZUQUIM, Judith; CYTRYNOWICZ, Roney. Notas para uma história do escotismo no Brasil: a psicologia escoteira e a teoria do caráter como pedagogia de civismo (1914-1937). Educação em Revista, Belo Horizonte, n. 35, jul. 2002. 